\title{
DEFORMABILIDADE E RESISTÊNCIA DE UM SOLO LATERÍTICO NÃO SATURADO
}

Tese apresentada à Escola de Engenharia de São de Carlos da Universidade de São Paulo como parte dos requisitos para a obtenção do Título de Doutora em Geotecnia.

Versão corrigida. Original se encontra disponível na Unidade que aloja o Programa.

Orientador: Prof. Dr. Orencio Monje Vilar

São Carlos 
AUTORIZO A REPRODUÇÃO TOTAL OU PARCIAL DESTE TRABALHO, POR QUALQUER MEIO CONVENCIONAL OU ELETRÔNICO, PARA FINS DE ESTUDO E PESQUISA, DESDE QUE CITADA A FONTE.

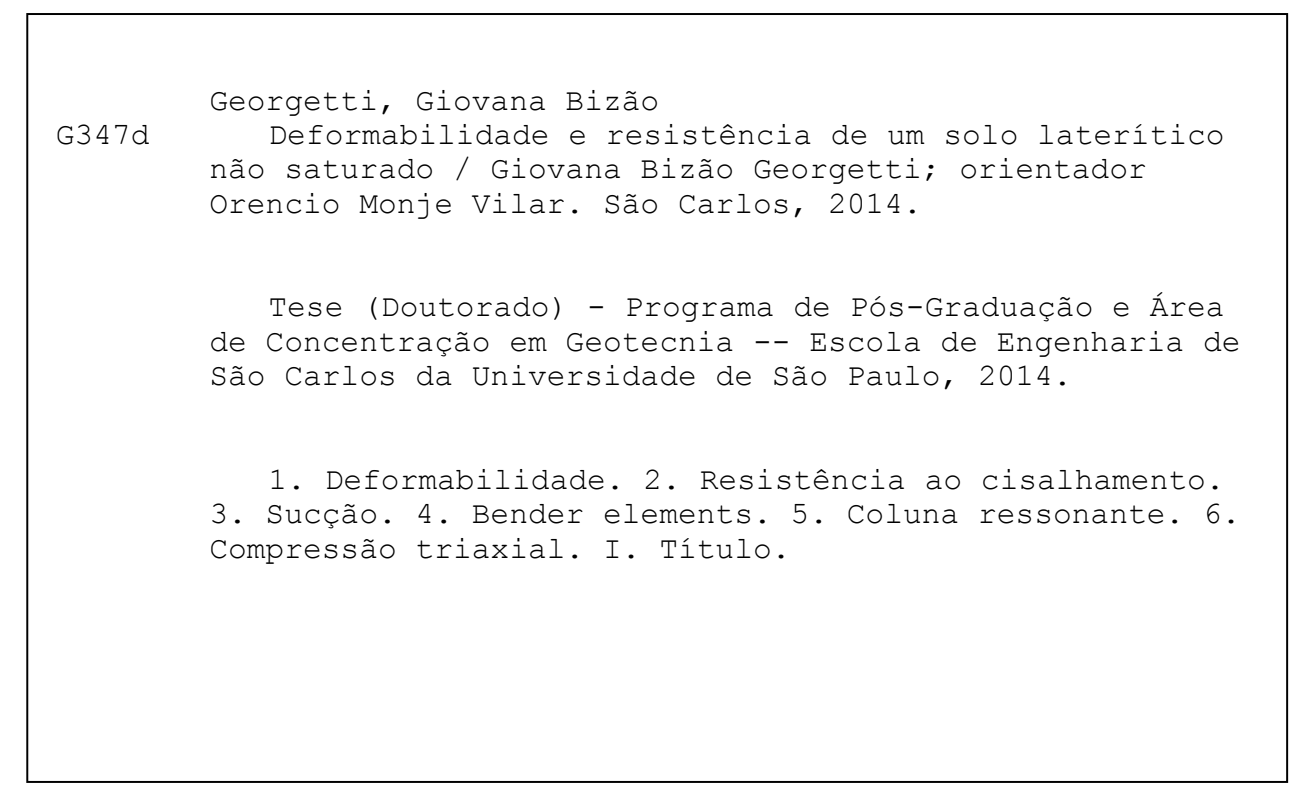




\section{FOLHA DE JULGAMENTO}

Candidata: Engenheira GIOVANA BIZÃO GEORGETTI.

Título da Tese: "Deformabilidade de um solo laterítico não saturado".

Data da defesa: 21/11/2014

Comissão Julgadora:

Resultado:

Prof. Titular Orencio Monje Vilar (Orientador) APROVADA (Escola de Engenharia de São Carlos/EESC)

Prof. Dr. Laureano René Hoyos

(University of Texas - Arlington)

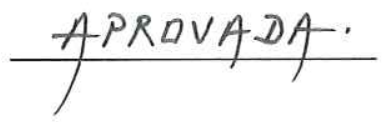

Dr. José Maria de Camargo Barros

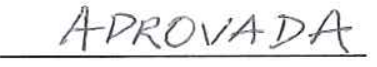

(Pesquisador do IPT)

Prof. Dr. Heraldo Luiz Giacheti

(Universidade Estadual Paulista "Júlio de Mesquita Filho"/UNESP-Bauru)

Dr. Miguel Angel Alfaro Soto ( Pesquisador da Universidade Estadual Paulista "Júlio de Mesquita Filho"/UNESP-Rio Claro)

Coordenador do Programa de Pós-Graduação em Geotecnia: Prof. Doutor Edmundo Rogério Esquivel

Presidente da Comissão de Pós-Graduação: Prof. Associado Paulo César Lima Segantine 

À minha família, que perto ou longe, se faz presença constante. 


\section{AGRADECIMENTOS}

Ao Prof. Orencio Monje Vilar, pela orientação, paciência e incentivo.

Ao Prof. Laureano René Hoyos, pela supervisão durante o doutorado sanduíche e pela ajuda profissional e pessoal durante este período.

Aos Prof. Fernando Antônio Medeiros Marinho e Alexandre Benetti Parreira, pelas sugestões no exame de qualificação.

Ao Prof. Heraldo Luiz Giacheti pelo empréstimo de equipamento e por compartilhar sua experiência no assunto desta pesquisa.

A todos os docentes da pós-graduação em Geotecnia da Escola de Engenharia de São Carlos, cujos ensinamentos foram fundamentais para minha formação.

Ao amigo Prof. Roger Augusto Rodrigues, pela troca de experiências e ajuda nos momentos cruciais.

Aos amigos da pós-graduação em Geotecnia, em especial a Ana Elisa Abreu, Juliana Lukiantchuki, Rafaela Faciola, Mariana Fernandes e Vinícius Peixoto, pela companhia, trocas de experiências acadêmicas e de vida, e pelas sempre boas risadas.

Aos amigos Jairo Yepes, Alejandro Bravo, Ujwalkumar Patil, Pourya Alikhani e Oleh Kinash, pela valiosa ajuda, pela companhia e pelos momentos de descontração em Arlington.

Aos técnicos Oscar dos Santos Neto e José Luís Guerra, pelo auxílio técnico e incentivo nos momentos de dificuldade.

Aos funcionários do Departamento de Geotecnia, pelo apoio durante o curso de pósgraduação.

À Coordenação de Aperfeiçoamento de Pessoal de Nível Superior (CAPES) e à Fundação de Amparo à Pesquisa do Estado de São Paulo (FAPESP), pelo suporte financeiro. 


\section{RESUMO}

Georgetti, G.B. (2014). Deformabilidade e resistência de um solo laterítico não saturado. São Carlos, 123p. Tese (Doutorado em Geotecnia) - Escola de Engenharia de São Carlos, Universidade de São Paulo.

A deformabilidade é uma propriedade fundamental em projetos geotécnicos. A constatação de que as deformações em várias obras de engenharia se situam na faixa de pequenas e muito pequenas deformações e as limitações das técnicas de ensaio em medir tal nível de deformações levaram ao desenvolvimento de técnicas com base em solicitações dinâmicas, dentre as quais, as de coluna ressonante e bender elements. Particularmente, o emprego da técnica de bender elements tem crescido devido à simplicidade de execução dos ensaios, e determinação do módulo de cisalhamento máximo dos solos. Diversos estudos acerca das propriedades deformacionais dos solos determinadas por este método têm sido conduzidos em solos saturados ou secos, não obstante, estudos desta natureza em solos não saturados ainda são relativamente escassos. Esta pesquisa investigou a influência de algumas variáveis, como a sucção e a tensão confinante sobre a deformabilidade de um solo laterítico não saturado típico do interior do Estado de São Paulo, empregando bender elements, coluna ressonante e compressão triaxial com instrumentação interna. Além disso, buscando uma caracterização mais completa deste solo, ensaios de compressão triaxial foram realizados para quantificar sua resistência ao cisalhamento. Os resultados destes ensaios sugeriram a ocorrência de encruamento em solo indeformado, e uma envoltória planar de resistência foi usada para representar a resistência ao cisalhamento da amostra compactada. Já no que se refere à deformabilidade, os resultados indicaram que a redução do teor de umidade de compactação, o aumento do confinamento isotrópico ou da sucção são responsáveis por um solo menos deformável. Dados dos ensaios com bender elements foram bem representados por uma função potencial quando o módulo de cisalhamento máximo e a sucção foram normalizados pela tensão confinante líquida. Para o solo compactado não saturado, também ensaiado em coluna ressonante, dados obtidos por ambas as técnicas foram comparados, notando-se velocidades de ondas de cisalhamento um pouco superiores para os ensaios com bender elements, que foram atribuídas às mais altas frequências nestes ensaios.

Palavras-chave: deformabilidade, resistência ao cisalhamento, sucção, bender elements, coluna ressonante, compressão triaxial. 


\begin{abstract}
Georgetti, G.B. (2014). Stiffness and strength of a lateritic unsaturated soil. São Carlos, 123p. PhD. Thesis - Escola de Engenharia de São Carlos, Universidade de São Paulo.

Stiffness is a fundamental property in geotechnical design. The fact that strains are in the smallto-very small strain range in several engineering works and the limitations of testing techniques in measuring such level of strains led to the development of dynamic techniques, such as resonant column and bender elements. Specifically, the bender element technique has been increasingly used due to the simplicity in performing tests and computing the maximum shear modulus of the soil. Several studies have been carried out to assess stiffness properties of dry or saturated soils via bender elements, however, studies of this nature are still relatively scarce in unsaturated soils. This research investigated the influence of some variables, like suction and confining stress, on the stiffness of a lateritic unsaturated soil, typical of São Paulo State, via bender element, resonant column and triaxial compression tests with local gauges. Furthermore, aiming at a more complete characterization of this soil, triaxial compression tests were performed in order to quantify its shear strength. Results from these tests suggested the occurrence of strain hardening on undisturbed specimens, and a planar shear strength envelope was used to represent the compacted sample data. Regarding soil stiffness, results indicated that it increases with a reduction in the compaction moisture content or an increase in isotropic confining stress or suction. Data from bender element tests were nicely represented by a power function when maximum shear modulus and suction were normalized by the net confining stress. Results of unsaturated compacted soil obtained from bender element and resonant column tests were compared and slightly larger shear wave velocities were noticed in bender element tests, which were attributed to the larger testing frequencies used in these tests.
\end{abstract}

Keywords: stiffness, shear strength, suction, bender elements, resonant column, triaxial compression. 


\section{LISTA DE FIGURAS}

\section{Capítulo 2}

Figura 2.1. Esquema ilustrativo da definição de sucção.

Figura 2.2. Ascensão da água em tubo capilar: (a) formação do menisco, (b) ascensão até o equilíbrio e (c) pressão na água após o equilíbrio. 7

Figura 2.3. Curva de retenção de água (adaptado de Fredlund e Xing, 1994). 8

Figura 2.4. Curvas de retenção de água típicas para solos arenosos, siltosos e argilosos (adaptado de Fredlund e Xing, 1994).

Figura 2.5. Variação do parâmetro $\chi$ com o grau de saturação para vários solos (Jennings e Burland, 1962).

Figura 2.6. Envoltória de ruptura tridimensional para solos não saturados utilizando as variáveis de estado $\left(\sigma-u_{a}\right)$ e $\left(u_{a}-u_{w}\right)$

Figura 2.7. Envoltória de resistência não linear em termos de sucção (Escario e Sáez, 1986).

Figura 2.8.Círculos de Mohr para diferentes sucções e variação do ângulo $\phi^{b}$ com a sucção matricial (Nyunt et al., 2011)

Figura 2.9. Relação não linear entre (a) tensão e deformação e (b) módulo de deformabilidade e deformação (adaptado de Atkinson, 2000).

Figura 2.10. Variação de $G / G_{\text {máx }}$ com a deformação cisalhante para areias (Seed e Idriss, 1970).

Figura 2.11. Histerese da curva tensão $v s$ deformação devido a solicitações cíclicas no solo. 22

Figura 2.12. Decaimento da amplitude de vibração livre com o tempo. 23

Figura 2.13. Cálculo do amortecimento a partir da resposta de frequência.

Figura 2.14. Variação da razão de amortecimento com a deformação cisalhante para areias e argilas (Seed e Idriss, 1970)

Figura 2.15. Faixas de deformações típicas para ensaios de laboratório e estruturas geotécnicas (adaptado de Atkinson, 2000) 26

Figura 2.16. Bender elements acoplados a cabeçote e pedestal de câmara triaxial. 27

Figura 2.17. Esquema de execução de ensaio com bender elements (Wykeham Farrance/Controls Group) 
Figura 2.18. Módulos de cisalhamento normalizados obtidos de (a) ensaios de coluna ressonante e (b) bender elements para uma areia mal graduada (Takkabutr, 2006). 31

Figura 2.19. Razões de amortecimento normalizadas obtidas de (a) ensaios de coluna ressonante e (b) bender elements para uma areia mal graduada (Takkabutr, 2006).

Figura 2.20. Comparação dos valores de módulo de cisalhamento máximo $\left(G_{o}\right)$ medidos em coluna ressonante e calculados por correlações empíricas (Barros et al., 1991). 33

\section{Capítulo 3}

Figura 3.1. Fluxograma do programa experimental. 36

\section{Capítulo 4}

Figura 4.1. Preparação dos corpos de prova (a) compactados, (b) indeformados, (c) para curvas de retenção e (d) porosimetria. 39

Figura 4.2. (a) Saturação e (b) secagem ao ar dos corpos de prova. (c) Contato com o papel filtro e (d) embalagem dos corpos de prova no ensaio de papel filtro.................................... 41

Figura 4.3. Equipamento de funil de placa porosa (Libardi, 1995). ..................................... 42

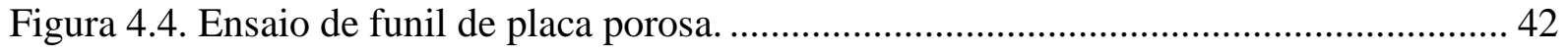

Figura 4.5. Penetrômetro de mercúrio (adaptado de www.micromeritics.com)....................... 43

Figura 4.6. Representação esquemática do conjunto de equipamentos para ensaio de

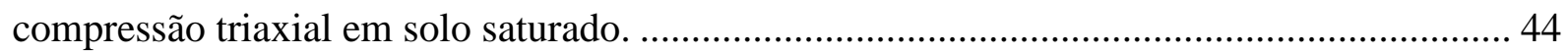

Figura 4.7. Pré-condicionamento dos corpos de prova para ensaios não saturados. ............... 46

Figura 4.8. (a) Representação esquemática dos equipamentos para ensaio com bender elements, e (b) e (c) adaptação de câmara triaxial e pedestal com bender element ................................ 49

Figura 4.9. Acessórios para a execução de ranhura para alocação de bender elements no solo.

Figura 4.10. Determinação do tempo de percurso da onda.

50

Figura 4.11. (a) Pedestal com pedra porosa de alta pressão de entrada de ar e bender element e (b) corpo de prova instrumentado para ensaio com bender elements em condição não saturada.

Figura 4.12. Equipamento para ensaio em coluna ressonante com controle de sucção. 53 
Figura 4.13. (a) Montagem do ensaio de coluna ressonante com sucção constante e (b) transdutor de proximidade.

Figura 4.14. Equipamento para ensaio em coluna ressonante com teor de umidade constante.

Figura 4.15. Sistema oscilador na coluna ressonante para ensaios com teor de umidade constante.

\section{Capítulo 5}

Figura 5.1. (a) Curva granulométrica e (b) de compactação do solo.

Figura 5.2. Curvas de retenção de água para (a) solo compactado em diferentes teores de umidade, e (b) solo compactado e indeformado. 59

Figura 5.3. Porosimetria do solo compactado em diferentes teores de umidade. 60

Figura 5.4. Porosimetria do solo compactado e indeformado. 61

Figura 5.5. Curvas de adensamento dos ensaios CU com solo compactado: (a) medidas na drenagem do corpo de prova e (b) da câmara interna.....

Figura 5.6. Curvas de adensamento dos ensaios CD com solo compactado: medidas na drenagem do corpo de prova.

Figura 5.7. Curvas de adensamento dos ensaios CD com solo indeformado: medidas na drenagem do corpo de prova.

Figura 5.8. Curvas $\left(\sigma_{1}-\sigma_{3}\right)$ vs deformação axial dos ensaios CU com solo saturado compactado.

Figura 5.9. Curvas $\left(\sigma_{1}-u_{w}\right) /\left(\sigma_{3}-u_{w}\right)$ vs deformação axial dos ensaios CU com solo saturado compactado.

Figura 5.10. Pressões neutras nos ensaios CU com solo saturado compactado. 66

Figura 5.11. Envoltória de resistência ao cisalhamento em termos de tensões efetivas para a representação por $\left(\sigma_{1}-u_{w}\right) /\left(\sigma_{3}-u_{w}\right)$ dos ensaios CU com solo compactado saturado. 66 Figura 5.12. Curvas tensão vs deformação axial dos ensaios CD com solo saturado compactado.

Figura 5.13. Deformações volumétricas nos ensaios CD com solo saturado compactado.

Figura 5.14. Envoltória de resistência ao cisalhamento dos ensaios CD com o solo compactado saturado 68 
Figura 5.15. Envoltória de resistência ao cisalhamento para o solo compactado saturado considerando os ensaios CD e CU em conjunto.

Figura 5.16. Curvas tensão vs deformação axial dos ensaios CD com solo saturado indeformado para tensões confinantes líquidas de (a) 50 e $200 \mathrm{kPa}$, e (b) 20, 100 e $400 \mathrm{kPa}$.

Figura 5.17. Deformações volumétricas nos ensaios CD com solo saturado indeformado para tensões confinantes líquidas de (a) 50 e $200 \mathrm{kPa}$, e (b) 20, 100 e $400 \mathrm{kPa}$. 70

Figura 5.18. Envoltória de resistência ao cisalhamento para o solo indeformado saturado a partir de ensaios CD...... 70

Figura 5.19. Curvas de adensamento do ensaio CW com solo compactado e sucção imposta de 15 kPa: (a) medidas na drenagem do corpo de prova e (b) da câmara interna. 72

Figura 5.20. Curva de adensamento do ensaio CW com solo compactado, sucção imposta de 15 $\mathrm{kPa}$ e confinamento líquido de $50 \mathrm{kPa}$ : efeito da variação de temperatura. 73 Figura 5.21. Estabilização da sucção no solo após adensamento do ensaio CW (a) com solo compactado e (b) indeformado com sucção imposta de $40 \mathrm{kPa}$. 74 Figura 5.22. Curvas (a) tensão-deformação, (b) variação da sucção e (c) deformação volumétrica do ensaio CW com solo compactado e ensaiado com sucção inicial de $40 \mathrm{kPa}$. 75 Figura 5.23. Curvas (a) tensão-deformação, (b) variação da sucção e (c) deformação volumétrica do ensaio CW com solo indeformado e ensaiado com sucção inicial de $40 \mathrm{kPa} .76$ Figura 5.24. Corpo de prova de amostra indeformada após o ensaio CW com sucção inicial de $40 \mathrm{kPa}$ 77

Figura 5.25. Envoltória planar de resistência ao cisalhamento para o solo compactado 78 Figura 5.26. Círculos de Mohr dos corpos de prova indeformados em ensaios CW com tensão confinante líquida de $50 \mathrm{kPa}$. 79

Figura 5.27. Envoltória planar de resistência ao cisalhamento para o solo indeformado. 80 Figura 5.28. Respostas típicas dos ensaios com bender elements em solo compactado saturado para os teores de umidade de compactação de (a) $11,2 \%$ e (b) $17,1 \%$. 81 Figura 5.29. Velocidade da onda de cisalhamento dos ensaios com bender elements para solo compactado com teores de umidade de (a) $11,2 \%$ e (b) $17,1 \%$ e ensaiados em condição saturada.

Figura 5.30. Variação do módulo de cisalhamento máximo com a tensão de confinamento para solo compactado em diferentes teores de umidade e ensaiado em condição saturada. 83 
Figura 5.31. Variação do módulo de cisalhamento máximo com a relação entre índice de vazios e índice de vazios inicial para solo compactado em diferentes teores de umidade e ensaiado em condição saturada.

Figura 5.32. Variação do módulo de cisalhamento máximo com a trajetória de tensão para solo compactado com teores de umidade de (a) 11,2\% e (b) 17,1\% ensaiado em condição saturada.

Figura 5.33. Respostas típicas dos ensaios com bender elements em solo compactado com 13,9\% de umidade para as tensões confinantes líquidas de (a) 100 e (b) $500 \mathrm{kPa}$. 87

Figura 5.34. Velocidade da onda de cisalhamento dos ensaios com bender elements para (a) solo compactado com 13,9\% e (b) solo indeformado, na sucção de $15 \mathrm{kPa}$. 88

Figura 5.35. Velocidades de onda de cisalhamento para (a) o solo compactado com teores de umidade de $12,8 \%$ e (b) $13,9 \%$, e (c) para o solo indeformado.

Figura 5.36. Módulo de cisalhamento máximo para (a) o solo compactado com teor de umidade de (a) $12,8 \%$ e (b) $13,9 \%$, e (c) para o solo indeformado. 90

Figura 5.37. Módulo de cisalhamento máximo do solo compactado com teor de umidade de 13,9\%: (a) representação tridimensional, (b) influência da tensão confinante líquida e (c) da sucção.

Figura 5.38. Normalização do módulo de cisalhamento máximo e da sucção pela tensão confinante. .94

Figura 5.39. Variação do módulo de cisalhamento máximo com a relação entre índice de vazios e índice de vazios inicial (a) para o solo compactado com teores de umidade de $12,8 \%$ e (b) $13,9 \%$, e (c) para o solo indeformado.

Figura 5.40. Variação do módulo de cisalhamento máximo com a trajetória de tensão (a) para solo compactado com teores de umidade de $12,8 \%$ e (b) $13,9 \%$, e (c) para o solo indeformado e ensaiado com sucção de $15 \mathrm{kPa}$.

Figura 5.41. (a) Curvas tensão vs deformação axial e (b) deformação volumétrica $v s$ deformação axial dos ensaios CD com instrumentação interna.

Figura 5.42. (a) Degradação do módulo de cisalhamento e do (b) módulo de cisalhamento normalizado do solo compactado saturado.

Figura 5.43. (a) Efeitos típicos da sucção e (b) do torque na resposta de frequência do solo em ensaios de coluna ressonante com sucção constante.

Figura 5.44. Laçadas de histerese dos corpos de prova com sucções de (a) 15 e (b) $100 \mathrm{kPa}$. 
Figura 5.45. Decaimento das vibrações livres para os corpos de prova com sucções de (a) 15 e (b) $100 \mathrm{kPa}$

Figura 5.46. (a) Curvas de degradação do módulo de cisalhamento e (b) razão de amortecimento normalizados dos ensaios de coluna ressonante com sucção constante. 105

Figura 5.47. (a) Efeito típico da tensão confinante e (b) da voltagem de entrada na resposta de frequência dos ensaios de coluna ressonante com teor de umidade constante. 107 Figura 5.48. Efeito típico do tempo de equilíbrio (a) no módulo de cisalhamento máximo e (b) na razão de amortecimento mínimo do solo. 108 Figura 5.49. Influência da tensão confinante e sucção no módulo de cisalhamento máximo e na razão de amortecimento mínimo dos ensaios de coluna ressonante com teor de umidade constante. 109

Figura 5.50. (a) Curvas de degradação do módulo de cisalhamento e (b) da razão de amortecimento dos ensaios de coluna ressonante com teor de umidade constante. 111 Figura 5.51. Curvas de (a) degradação do módulo de cisalhamento e (b) da razão de amortecimento normalizados dos ensaios de coluna ressoante com teor de umidade constante.

Figura 5.52. Comparação entre velocidades de ondas de cisalhamento obtidas por diferentes técnicas. 114

\section{Anexo}

Figura A.1. Curvas (a) tensão-deformação, (b) variação da sucção e (c) deformação volumétrica do ensaio CW com solo compactado e ensaiado com sucção inicial de $15 \mathrm{kPa}$.

Figura A.2. Curvas (a) tensão-deformação, (b) variação da sucção e (c) deformação volumétrica do ensaio CW com solo compactado e ensaiado com sucção inicial de $100 \mathrm{kPa}$. 128 Figura A.3.Curvas (a) tensão-deformação, (b) variação da sucção e (c) deformação volumétrica do ensaio CW com solo indeformado e ensaiado com sucção inicial de $15 \mathrm{kPa}$. 129 Figura A.4. Curvas (a) tensão-deformação, (b) variação da sucção e (c) deformação volumétrica do ensaio CW com solo indeformado e ensaiado com sucção inicial de $80 \mathrm{kPa}$. 130 


\section{LISTA DE TABELAS}

\section{Capítulo 2}

Tabela 2.1. Parâmetros de resistência de solos naturais brasileiros não saturados (De Campos, 1997)

Tabela 2.2. Ensaios de compressão triaxial para solos não saturados (adaptado de Fredlund e Rahardjo, 1993).

Tabela 2.3. Ensaios de campo mais utilizados para determinação do módulo de cisalhamento dos solos (Barros e Hachich, 1998). 25

Tabela 2.4. Ensaios de laboratório mais utilizados para determinação do módulo de cisalhamento e da razão de amortecimento dos solos (Barros e Hachich, 1998). 26

\section{Capítulo 5}

Tabela 5.1. Índices físicos médios de moldagem dos corpos de prova para curvas de retenção de água. 58

Tabela 5.2. Parâmetros de ajuste das curvas de retenção ao modelo de Fredlund e Xing (1994).

Tabela 5.3. Índices físicos de moldagem dos corpos de prova para ensaio de resistência ao cisalhamento em condição saturada.

Tabela 5.4. Índices físicos de moldagem dos corpos de prova para ensaio de resistência ao cisalhamento em condição não saturada. 71

Tabela 5.5. Índices físicos de moldagem dos corpos de prova compactados para ensaio com bender elements em condição saturada. 80

Tabela 5.6. Parâmetros dos ajustes de modelos potenciais para os ensaios com solo compactado saturado em ensaios com bender elements (Eq. 5.2).

Tabela 5.7. Índices físicos de moldagem dos corpos de prova compactados para ensaio com bender elements em condição não saturada. 86 Tabela 5.8. Parâmetros dos ajustes de modelos potenciais para os ensaios com solo não saturado (Eq. 5.2). 
Tabela 5.9. Parâmetros de ajustes potenciais para o módulo de cisalhamento máximo normalizado (Eq. 5.4).

Tabela 5.10. Índices físicos de moldagem dos corpos de prova compactados para ensaio de deformabilidade em compressão triaxial em condição saturada.......................................... 98 Tabela 5.11. Índices físicos dos corpos de prova compactados para ensaio de deformabilidade em compressão triaxial em condição não saturada (Eq. 5.8). 100 Tabela 5.12. Índices físicos de moldagem dos corpos de prova compactados para ensaio em coluna ressonante em condição não saturada. 101 Tabela 5.13. Parâmetros de ajuste das curvas $G / G_{\text {máx }}$ e $D / D_{\min } v s \gamma$ dos ensaios de coluna ressonante com sucção constante (Eq. 5.8 e 5.10). 106 Tabela 5.14. Parâmetros dos ajustes de modelos potenciais para os ensaios com solo compactado não saturado em ensaios de coluna ressonante com teor de umidade constante (Eq. $5.2)$. 109

Tabela 5.15. Parâmetros de ajuste das curvas $G / G_{\text {máx }}$ e $D / D_{\min } v s \gamma$ dos ensaios de coluna ressonante com teor de umidade constante (Eq. 5.8 e 5.10). 113 


\section{LISTA DE SÍMBOLOS}

\section{Símbolos do alfabeto latino}

$A_{1}, A_{n+1}$ : amplitudes de vibração nos ciclos 1 e $n+1$, respectivamente

$a_{1}, m_{1}, n_{1}$ : parâmetros de ajuste do modelo de Fredlund e Xing (1994)

$a_{2}, m_{2}, n_{2}$ : parâmetros de ajuste do modelo de van Genuchten (1980)

$A_{\text {máx: }}$ amplitude máxima

$C(\psi)$ : função de correção do modelo de Fredlund e Xing (1994)

$c^{\prime}$ : coesão efetiva

$d$ : coeficiente de amortecimento

$D$ : razão de amortecimento

$d_{c}$ : coeficiente de amortecimento crítico

$D_{c p}$ : diâmetro do corpo de prova

$D_{m i n}$ : razão de amortecimento mínimo

$e$ : índice de vazios

E: módulo longitudinal ou módulo de Young

$e_{i}$ : índice de vazios inicial

$E_{o}, E_{\text {máx: }}$ módulo longitudinal máximo

$E_{\text {sec }}$ : módulo longitudinal secante

$E_{\text {tan }}$ : módulo longitudinal tangente

$f_{1}, f_{2}$ : frequências associadas à meia potência $\left(0,707 A_{\text {máx }}\right)$

$f_{\text {emitida: }}$ frequência da onda emitida

$f_{r}$ : frequência de ressonância (associada a $A_{\text {máx}}$ )

$g$ : aceleração da gravidade

$G$ : módulo transversal ou de cisalhamento

$G_{m a ́ x}, G_{o}$ : módulo de cisalhamento máximo

$G_{s e c}$ : módulo de cisalhamento secante

$h_{c}$ : altura de ascensão capilar

I: momento polar de inércia de massa do corpo de prova

$I_{0}$ : momento polar de inércia de massa do cabeçote e da placa de fixação do sistema oscilador no cabeçote 
$k$ : coeficiente de mola

$L$ : comprimento do corpo de prova

$L_{t t}$ : distância entre as extremidades em balanço dos bender elements

$m$ : massa

$M_{w}$ : massa molecular da água

n: número de ciclos

$p$ : diferencial de pressão na interface líquido-gás

$p_{a}, P_{o}$ : pressão atmosférica

$p_{v} / p_{v s}:$ umidade relativa do ar

$p_{v}$ : pressão parcial de vapor

$p_{v s}$ : pressão de vapor de saturação

$R$ : constante de gases ideais

$r$ : raio do tubo capilar

$r^{2}$ : coeficiente de determinação

$S_{l}$ : área da laçada de histerese

$S_{r}$ : grau de saturação

$S_{r i}$ : grau de saturação inicial

$S_{r r}$ : grau de saturação residual

$S_{r s}$ : grau de saturação máximo

$T$ : temperatura absoluta

$T_{s}$ : tensão superficial na água

$u_{a}$ : pressão no ar

$u_{w}$ : pressão na água ou pressão neutra

$V$ : volume total

$V_{r}$ : velocidade de propagação da onda Rayleigh

$V_{s}$ : velocidade de propagação da onda de cisalhamento

$v_{w}$ : volume específico da água

$w$ : teor de umidade gravimétrico

$w_{\text {médio: }}$ : teor de umidade médio

$w_{o ́ t}$ : teor de umidade ótimo

$w_{\text {papel }}$ : teor de umidade gravimétrico do papel filtro 


\section{Símbolos do alfabeto grego}

$\alpha$ : ângulo de contato entre sólido e líquido

$\beta_{1}, \beta_{2}$ : parâmetros empíricos (Eq. 5.2)

$\gamma$ : deformação cisalhante

$\gamma_{c}$ : deformação cisalhante na laçada de histerese

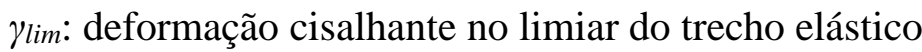

$\delta$ : decremento logarítmico da amplitude de vibração

$\Delta$ : variação

$\varepsilon_{a}$ : deformação axial

$\varepsilon_{o}$ : deformação no limiar do trecho elástico

$\varepsilon_{r}$ : deformação radial

$\varepsilon_{v}$ : deformação volumétrica

$\eta_{1}, \eta_{2}, \eta_{3}:$ parâmetros empíricos (Eq. 5.8)

$\theta$ : teor de umidade volumétrico

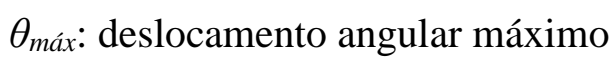

$\theta_{r}$ : teor de umidade volumétrico residual

$\theta_{s}$ : teor de umidade volumétrico de saturação

$\kappa_{1}, \kappa_{2}$ : parâmetros empíricos (Eq. 5.4)

$\lambda$ : comprimento da onda

$\mu_{1}, \mu_{2}, \mu_{3}$ : parâmetros empíricos (Eq. 5.10)

$\rho$ : massa específica do solo

$\rho_{d}$ : massa específica aparente seca

$\rho_{w}$ : massa específica da água

$\sigma$ : tensão normal total

$\sigma$ ': tensão normal efetiva

$\sigma_{1}:$ tensão principal maior

$\sigma_{3}$ : tensão principal menor ou tensão confinante isotrópica

$\sigma_{o}$ : tensão confinante em Takkabutr (2006)

$\left(\sigma-u_{a}\right)$ : tensão normal líquida

$\left(\sigma_{1}-u_{w}\right) /\left(\sigma_{3}-u_{w}\right)$ : relação entre tensões principais líquidas

$\left(\sigma_{1}-\sigma_{3}\right)$ : diferença de tensões principais

$\left(\sigma_{3}-u_{a}\right)$ : tensão confinante líquida para o solo não saturado 
$\left(\sigma_{3}-u_{w}\right)$ : tensão confinante líquida para o solo saturado

$\left(\sigma_{3}-u_{w}\right)_{\mathrm{c}}$ : tensão confinante líquida no adensamento para o solo saturado

$\tau$ : tensão cisalhante ou resistência ao cisalhamento

v: coeficiente de Poisson

$\chi$ : parâmetro relacionado ao grau de saturação do solo (Bishop, 1959)

$\psi,\left(u_{a}-u_{w}\right):$ sucção

$\psi_{r}$ : sucção associada ao teor de umidade residual (Fredlund e Xing, 1994)

$\phi ’$ ângulo de atrito interno efetivo

$\not b$ : ângulo de atrito interno com relação à sucção 


\section{SUMÁRIO}

1. INTRODUÇÃO

2. REVISÃO BIBLIOGRÁFICA..................................................................

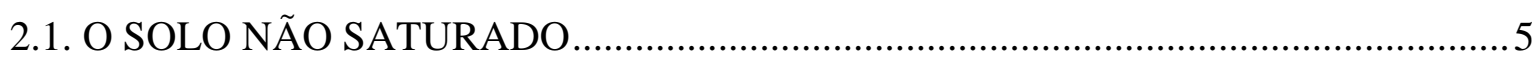

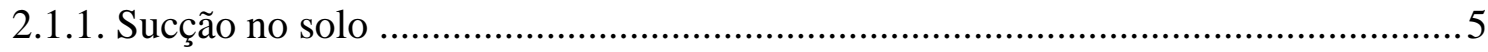

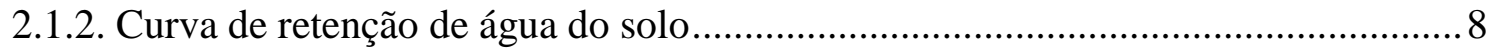

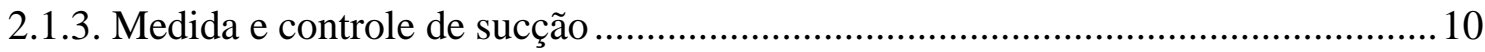

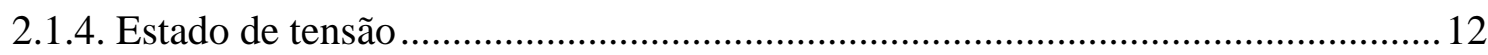

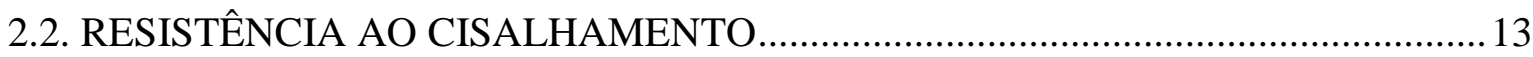

2.2.1. Determinação experimental da resistência....................................................... 16

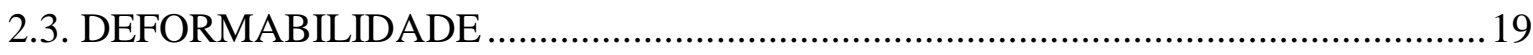

2.3.1. Determinação experimental das propriedades deformacionais ..............................2 24

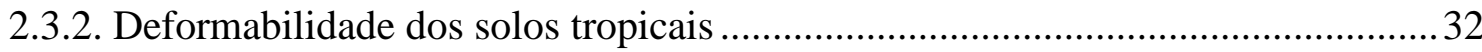

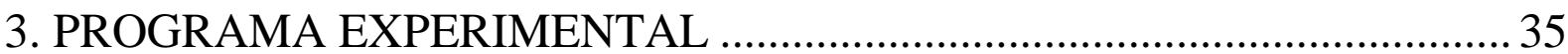

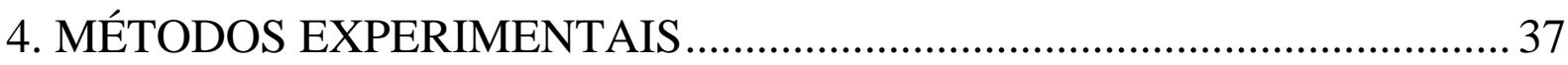

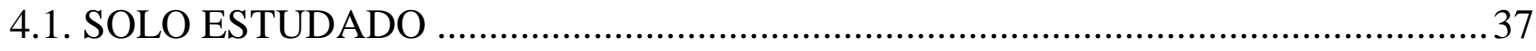

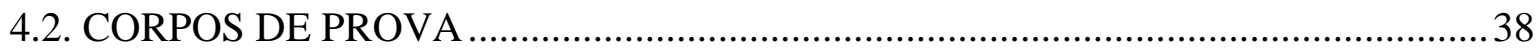

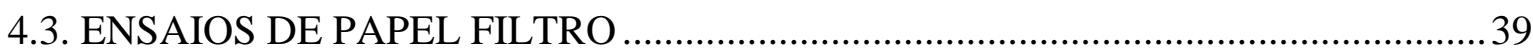

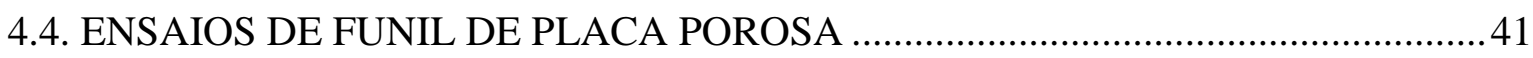

4.5. ENSAIOS DE POROSIMETRIA POR INTRUSÃO DE MERCÚRIO ....................... 42

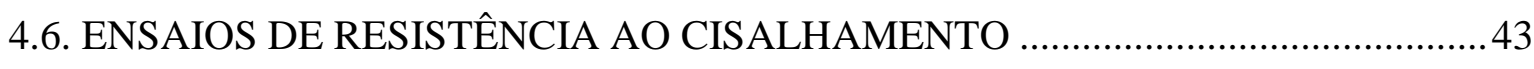

4.6.1. Ensaios adensado-drenado e adensado-não drenado........................................... 45

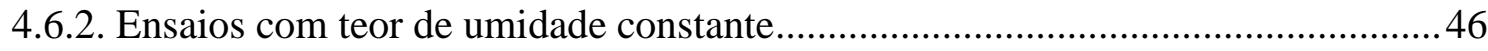

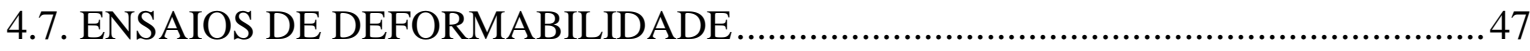

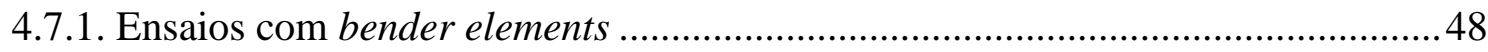

4.7.2. Ensaios de compressão triaxial com instrumentação interna................................52

4.7.3. Ensaios com sucção constante em coluna ressonante .........................................52 


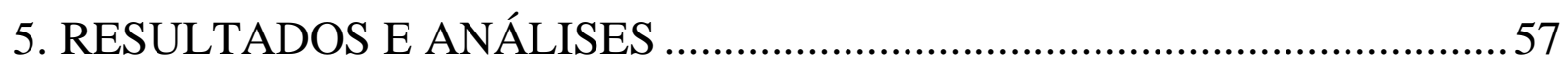

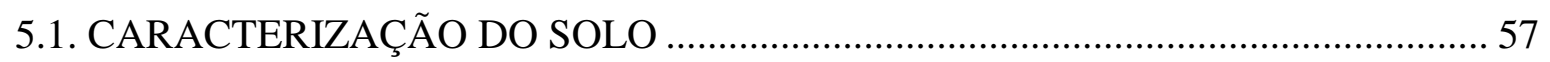

5.2. ENSAIOS DE RESISTÊNCIA AO CISALHAMENTO ............................................. 61

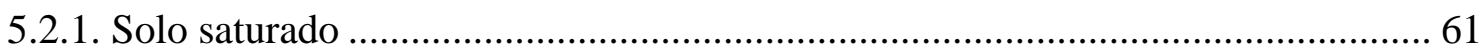

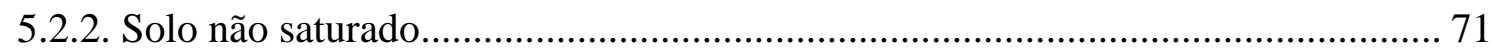

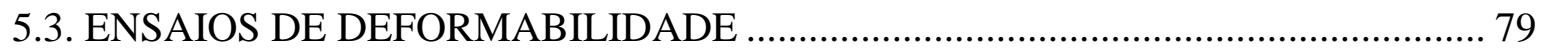

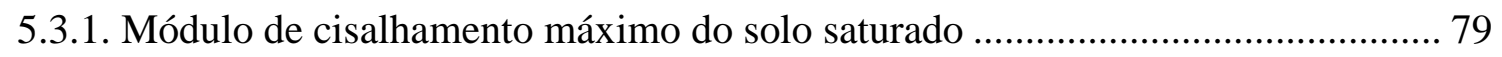

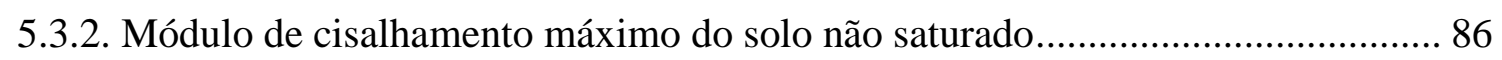

5.3.3. Degradação do módulo de cisalhamento do solo saturado ................................... 95

5.3.4. Degradação do módulo de cisalhamento e amortecimento do solo não saturado 100

5.3.5. Comparação entre técnicas de ensaio

6. CONCLUSÕES E SUGESTÕES PARA INVESTIGAÇÕES FUTURAS.. 115

6.1. CONCLUSÕES 115

6.2. RECOMENDAÇÕES PARA FUTURAS PESQUISAS ........................................... 118

REFERÊNCIAS BIBLIOGRÁFICAS

ANEXO: RESULTADOS DOS ENSAIOS DE COMPRESSÃO TRIAXIAL COM SOLO NÃO SATURADO 127 


\section{INTRODUÇÃO}

As propriedades deformacionais dos solos são reconhecidas como fundamentais no projeto e análise de diversas obras geotécnicas, sejam estas submetidas a carregamentos estáticos ou dinâmicos (Richart et al., 1970; Jardine et al., 1986). A deformabilidade pode ser caracterizada pelo módulo de cisalhamento e pela razão de amortecimento viscoso, que são principalmente afetados pela amplitude de deformações. Dados de ensaios de campo apresentados por Burland (1989) indicaram que as deformações nos maciços de solo abaixo e no entorno das estruturas permanecem, em grande quantidade de situações, menores que $0,1 \%$. Contudo, para a análise e modelação de problemas reais, não é apenas o estado final de deformações que importa, mas também as condições iniciais, pois é destas condições que o maciço de solo começa a ser solicitado. Assim, fazem-se necessárias medidas precisas da deformabilidade dos solos para níveis de deformações pequenas e muito pequenas.

Um elemento-chave para o entendimento da dependência da deformabilidade com relação à deformação é o limiar elástico de deformação no solo, que define o limite superior do intervalo de muito pequenas deformações, onde o solo se comporta praticamente como um material elástico linear. Este limite é geralmente assumido como ocorrendo em torno de 0,001\%, e depois disso, na faixa de pequenas deformações, entre $0,001 \%$ e $1 \%$, a dependência da deformação é mais pronunciada. Neste caso, o aumento das deformações resulta em amolecimento do material, seguindo um comportamento elasto-plástico. Quando o solo alcança grandes deformações, acima de $1 \%$, o módulo de cisalhamento já se encontra tipicamente degradado a cerca de dez por cento do seu valor máximo.

Ensaios de laboratório e de campo são utilizados na medida de propriedades deformacionais do solo. Dentre as técnicas de campo, estão disponíveis os ensaios pressiométricos e geofísicos, por exemplo. Quando se tratam de ensaios de laboratório, as limitações das técnicas convencionais na medida de baixas deformações têm sido superadas pela utilização de métodos alternativos. Na zona de pequenas deformações, o uso de transdutores locais fornece um nível de precisão adequado. Já quando se pretende avaliar o módulo de cisalhamento máximo e a razão de amortecimento mínimo, que ocorrem na faixa de muito pequenas deformações, métodos dinâmicos como o de coluna ressonante ou de bender elements são indicados. 
Considerando a complexidade destas técnicas de laboratório, o emprego de transdutores locais de deslocamento requer maior nível de especialização técnica, o que torna difícil seu uso rotineiro, como salientado por Atkinson (2000). As técnicas dinâmicas mencionadas são de mais simples execução e, os bender elements particularmente têm mostrado bastante versatilidade, sendo inclusive instalados em colunas ressonantes, como reportado por Florez (2010), por exemplo.

Enquanto a utilização da técnica de coluna ressonante já está amplamente disseminada e normatizada (ASTM, 2007), o uso de bender elements tem recebido crescente atenção de pesquisadores nas duas últimas décadas. Contribuições têm sido feitas no sentido de discutir o desempenho e a interpretação dos resultados provenientes destes ensaios e caracterizar diferentes materiais geotécnicos quanto à deformabilidade em muito pequenas deformações, inclusive avaliando efeitos de anisotropia e histórico de tensões (Pennington et al. 2001; Lee e Santamarina, 2005; Valle-Molina e Stokoe, 2012; entre outros). Em solos não saturados, o emprego de bender elements é ainda incipiente, e exemplos podem ser encontrados em Marinho et. al. (1995), Takkabutr (2006), Nyunt et al. (2011) e Ng e Xu (2012).

Os solos não saturados ocorrem naturalmente em vastas áreas em regiões de climas tropical e subtropical, e ainda são frequentemente encontrados em obras geotécnicas como bases de pavimentos e aterros diversos. Estes solos se diferenciam dos solos saturados pela ocorrência de sucção na água em seus poros, que é originada da interação ar-água-partículas sólidas. A sucção influencia o comportamento de solos não saturados aumentando a sua resistência e reduzindo a compressibilidade, dentre outras interferências.

O comportamento geotécnico de solos não saturados, especialmente de solos arenosos, típicos de vastas áreas do Estado de São Paulo, tem sido estudado há algum tempo (Röhm, 1992; Machado, 1998; Calle, 2000). Estes solos servem de fundação para várias obras e são fonte muito utilizada como material de construção para pavimentos, barragens e aterros. Neste sentido, esta pesquisa teve o objetivo de dar continuidade aos trabalhos já realizados na Escola de Engenharia de São Carlos (EESC/USP) na avaliação das características mecânicas e deformacionais deste solo arenoso e laterítico, enfocando a determinação do comportamento deformacional desse solo ao nível das pequenas e muito pequenas deformações. O programa experimental envolveu ensaios com bender elements em amostras indeformadas e compactadas saturadas e não saturadas, coluna ressonante usando amostras compactadas não saturadas, e ensaios triaxiais com transdutores locais em amostras compactadas saturadas. Com isso, foi possível analisar a relação entre a deformabilidade e a sucção e outras variáveis, como o nível de confinamento, além de se poder verificar a diferença de comportamento do solo em suas 
condições naturais, isto é, indeformado, e após compactação. Acessoriamente, o estudo permitiu conhecer a resistência ao cisalhamento, tanto em condição indeformada como compactada, saturada e não saturada, buscando-se uma caracterização mais completa do comportamento mecânico desse solo típico. Como implicação prática, os resultados desta pesquisa podem ser usados como referência na seleção de parâmetros de projeto e na análise de obras geotécnicas que utilizam este solo, ou similares, como material de construção ou fundação. 


\section{REVISÃO BIBLIOGRÁFICA}

\subsection{O SOLO NÃO SATURADO}

Os solos não saturados se diferenciam dos solos saturados basicamente pela ocorrência de uma fase gasosa em seus poros concomitantemente à fase líquida. Enquanto o comportamento dos solos saturados é abordado pela Mecânica dos Solos tradicional, as peculiaridades inerentes à coexistência de duas fases fluidas nos poros do solo tornam o entendimento de seu comportamento mecânico e hidráulico mais complexo. Um conceito essencial para esse entendimento é o da sucção, que representa a avidez que um solo tem por água.

\subsubsection{Sucção no solo}

A interação entre as fases líquida, gasosa e sólida de um solo não saturado, doravante tratadas como água, ar e sólidos, respectivamente, implica uma série de consequências como o surgimento da sucção na água intersticial. Fisicamente, a sucção total no solo é definida como “a pressão manométrica negativa, relativa à pressão externa de gás na água do solo, à qual um reservatório de água pura deve ser submetido para estar em equilíbrio através de uma membrana semipermeável com a água do solo" (Aitchison, 1965). Esta definição pode ser esquematizada como na Figura 2.1, onde o ar se encontra sob uma certa pressão $u_{a}$, e a água pura encontra-se sob uma pressão $u_{w}$. Separando o reservatório de água pura do solo, encontra-se uma membrana semipermeável, isto é, uma membrana que permite o fluxo de água, mas não o de solutos. Para que a água pura livre esteja em equilíbrio com a água intersticial, a pressão $u_{w}$ deve ser tal que $u_{a}-u_{w}$ seja igual à avidez do solo por água, ou seja, à sucção. Quando a pressão atmosférica é tomada como referencial, como geralmente ocorre em situações de campo, a pressão na água do solo assume valores negativos.

Ainda na Figura 2.1, a membrana semipermeável impede a transferência de solutos da água do solo para a água pura, indicando a existência de uma parcela de sucção devida à osmose. De fato, a sucção total no solo é composta pelas parcelas osmótica e matricial. A sucção osmótica tem origem na diferença de concentração de duas soluções, e tem sua importância na análise de problemas de ordem ambiental, como a transmissão de poluentes por exemplo, e em 
solos expansivos. Já a sucção matricial é inerente à matriz do solo, e ocorre em função dos fenômenos de capilaridade e adsorção. De acordo com Fredlund e Rahardjo (1993), dentre as componentes de sucção, a matricial é a mais afetada nos problemas práticos da engenharia geotécnica envolvendo solos não saturados, sendo que variações na sucção osmótica são geralmente menos significativas.

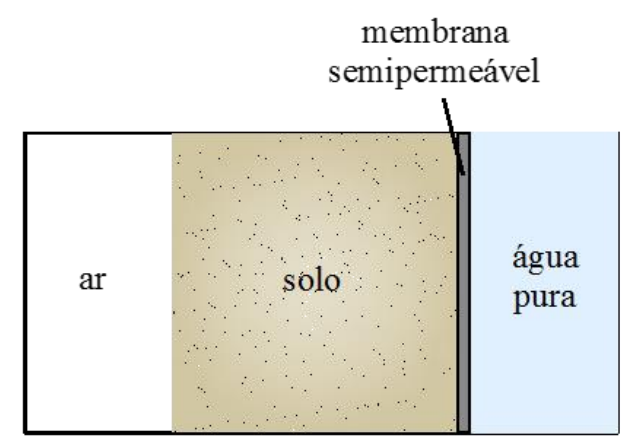

Figura 2.1. Esquema ilustrativo da definição de sucção.

O fenômeno da capilaridade pode ser explicado por uma analogia entre os poros do solo e tubos capilares de pequeno diâmetro, como apresentado por Hillel (1971) por exemplo. Para a representação deste fenômeno, toma-se um tubo capilar mergulhado em água livre como na Figura 2.2 (a).

Neste tubo ocorre a formação de um menisco em decorrência das forças atuantes na superfície da água no contato com o tubo. São elas, forças moleculares de atração coesiva do líquido e atração adesiva entre o sólido e a partícula de água, e a força da gravidade, que tem magnitude desprezível em comparação com as demais. A relação entre estas forças é responsável por uma tensão superficial na água $\left(T_{s}\right)$ e pelo ângulo de contato $(\alpha)$ formado entre a tangente da superfície líquida e a parede do sólido. No caso da Figura 2.2, tem-se atração entre o fluido e o sólido, o que gera um ângulo de contato agudo e a formação de uma superfície côncava. Como descrito por Hillel (1971), no caso de um menisco côncavo para o ar, a pressão do líquido sob o menisco será menor que a pressão atmosférica. A diferença de pressões na água externa ao tubo e sob o menisco $(p)$ faz com que a água no interior do tubo se desloque até o equilíbrio, atingindo uma altura $h_{c}$, como ilustrado na Figura 2.2 (b). A altura de ascensão capilar $h_{c}$ pode ser obtida do equilíbrio de forças verticais atuantes na água interna ao tubo. $\mathrm{O}$ perfil de pressão na água capilar após o equilíbrio é mostrado na Figura 2.2 (c). Assumindo a curvatura do menisco como esférica, tem-se 


$$
h_{c}=\frac{2 T_{s}}{\rho_{w} g r} \cos \alpha
$$

em que $\rho_{w}$ é a massa específica da água, $g$ é a aceleração da gravidade e $r$ é o raio do tubo capilar. Nota-se que a altura de ascensão capilar, e portanto a sucção na água, é inversamente proporcional ao raio do tubo, que nesta analogia representa o poro do solo.

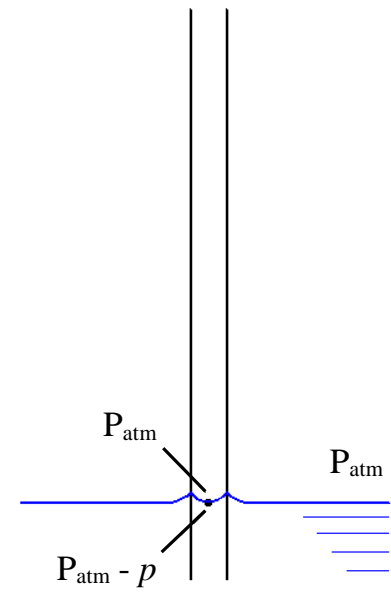

(a)

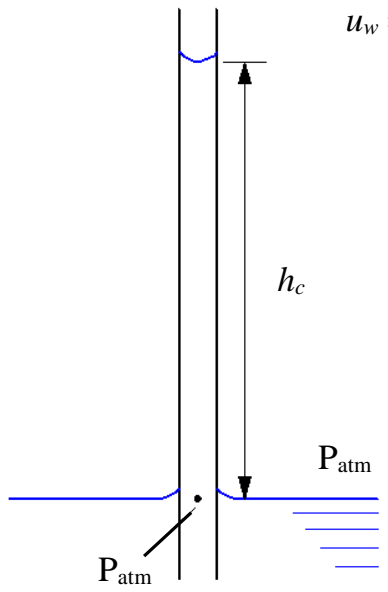

(b)

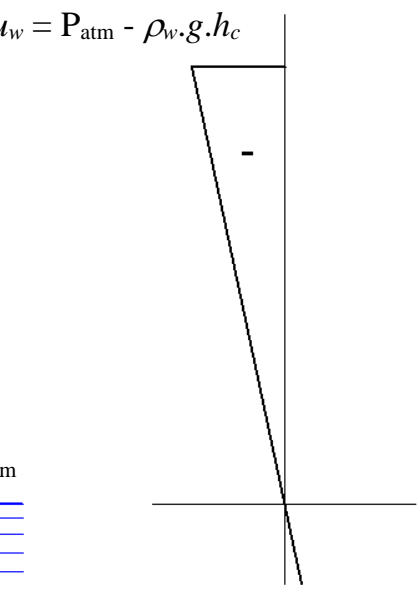

(c)

Figura 2.2. Ascensão da água em tubo capilar: (a) formação do menisco, (b) ascensão até o equilíbrio e (c) pressão na água após o equilíbrio.

No que se refere à adsorção, Hillel (1971) a descreve como um fenômeno de interface resultante da atuação de forças eletrostáticas entre moléculas de diferentes fases nas superfícies de contato. Dentre as causas da adsorção de água pelos sólidos do solo estão a ocorrência de cargas negativas na superfície e a presença de cátions trocáveis nas proximidades dos minerais de argila. A camada de água adsorvida no entorno dos sólidos pode ter propriedades mecânicas de resistência e viscosidade que diferem da água líquida livre à mesma temperatura, e é o mecanismo que causa a forte retenção de água pelos solos argilosos a altas sucções.

$\mathrm{Na}$ natureza, o solo encontra-se em um equilíbrio dinâmico com a atmosfera, e deste modo, a pressão parcial de vapor na água atmosférica $\left(p_{v}\right)$, ou a umidade relativa do $\operatorname{ar}\left(p_{v} / p_{v s}\right)$, se relacionam com a sucção total no solo $(\psi)$ pela equação de Kelvin:

$$
\psi=-\frac{R T}{v_{w} M_{w}} \ln \left(\frac{p_{v}}{p_{v s}}\right)
$$


na qual $R$ é a constante dos gases ideias, $T$ é a temperatura absoluta, $v_{w}$ é o volume específico da água, $M_{w}$ é a massa molecular da água e $p_{v s}$ é a pressão de vapor de saturação.

\subsubsection{Curva de retenção de água do solo}

A sucção do solo está intimamente relacionada com a quantidade de água em seus vazios, e esta relação é representada quantitativamente pela curva de retenção de água do solo.

Exemplos típicos destas curvas estão ilustrados na Figura 2.3. Neste caso, a sucção, que pode ser total ou qualquer uma de suas parcelas, foi plotada em função do teor de umidade volumétrico, que poderia ser também substituído pelo teor de umidade gravimétrico ou grau de saturação. As curvas apresentadas nesta figura refletem as condições de secagem (ou drenagem) do solo saturado e umedecimento do solo seco, que são comumente determinadas em laboratório. As diferenças de teores de umidade observadas para uma mesma sucção se devem a um fenômeno de histerese, causado por fatores como não uniformidade geométrica dos poros, efeito do ângulo de molhamento, aprisionamento de ar nos vazios e alteração da estrutura do solo resultantes de expansão ou contração (Hillel, 1971). Na prática, as variações de teor de umidade e suas correspondentes sucções se situam em trajetórias intermediárias, que acontecem entre os limites definidos por essas curvas.

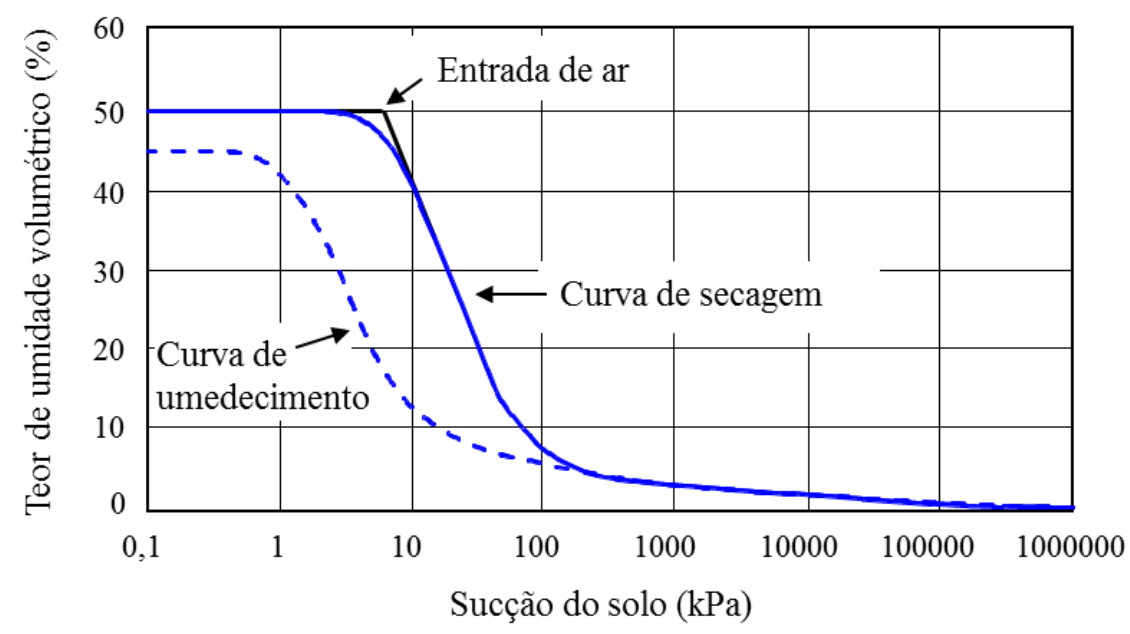

Figura 2.3. Curva de retenção de água (adaptado de Fredlund e Xing, 1994).

Uma característica importante da curva de retenção é a sucção de entrada de ar, que caracteriza a sucção a partir da qual o ar entra nos maiores poros do solo provocando a drenagem de água. Assim, o solo permanece saturado para sucções menores que a entrada de ar e encontra- 
se não saturado para sucções superiores, o que reflete diretamente em suas características hidráulicas e mecânicas. Fredlund et al. (1987), por exemplo, discute a implicação da entrada de ar na resistência ao cisalhamento de solos não saturados, assinalando diferenças de comportamento do solo antes e depois deste valor característico, como se discute mais adiante no item 2.2 .

A Figura 2.4 mostra curvas de retenção de água típicas para diferentes tipos de solo, que exemplifica como a sucção de entrada de ar e o formato das curvas se alteram com o tipo de solo. Outros fatores como histórico de tensões e distribuição do tamanho dos poros também são reconhecidos como responsáveis pela forma destas curvas (Fredlund e Xing, 1994; Hu et al., 2013).

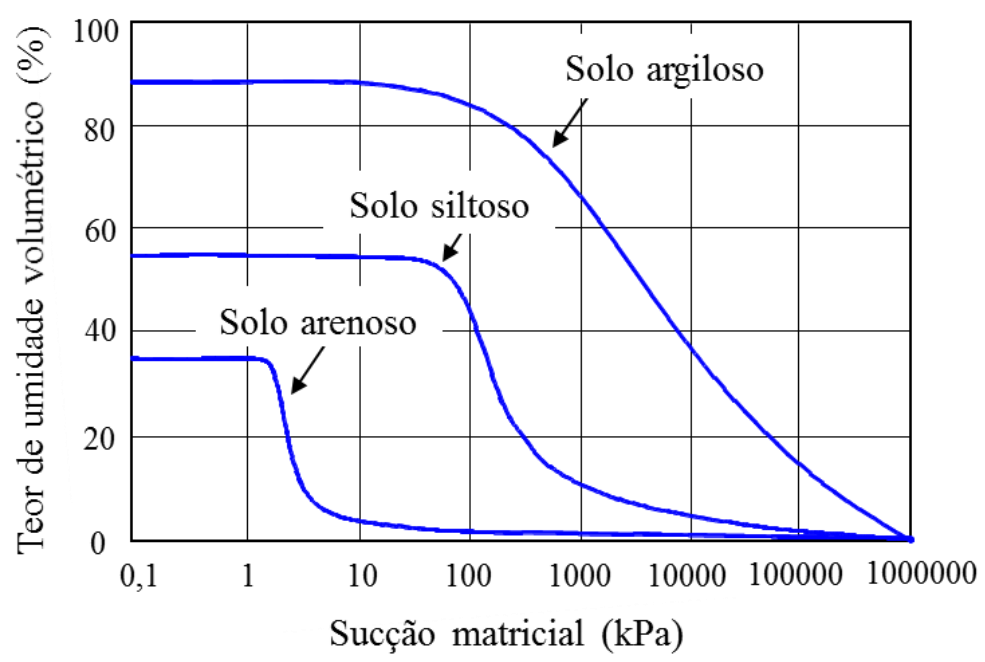

Figura 2.4. Curvas de retenção de água típicas para solos arenosos, siltosos e argilosos (adaptado de Fredlund e Xing, 1994).

Dada a ampla utilização da curva de retenção na caracterização do solo não saturado, e ainda na previsão de condutividade hidráulica e resistência ao cisalhamento do solo (Fredlund et al., 1994; Öberg e Sällfors, 1997; entre outros), modelos matemáticos têm sido propostos para sua representação. Leong e Rahardjo (1997) reúnem alguns destes modelos e sugerem o uso da função proposta por Fredlund e Xing (1994) por apresentar os melhores resultados de ajustes em comparação às demais funções analisadas.

O modelo apresentado por Fredlund e Xing (1994) é

$$
\theta=C(\psi) \frac{\theta_{s}}{\left\{\ln \left[e+\left(\psi / a_{1}\right)^{n_{1}}\right]\right\}^{m_{1}}} \operatorname{com} C(\psi)=\frac{-\ln \left(1+\psi / \psi_{r}\right)}{\ln \left[1+\left(10^{6} / \psi_{r}\right)\right]}+1
$$


no qual $\theta$ é o teor de umidade volumétrico, $\theta_{s}$ é o teor de umidade volumétrico na saturação, $a_{l}$, $n_{l}$ e $m_{l}$ são parâmetros empíricos de ajuste e $\psi_{r}$ é a sucção para o teor de umidade residual. Este modelo assume que a umidade no solo chega a zero quando a sucção atinge $10^{6} \mathrm{kPa}$. No entanto, quando se pretende estimar o teor de umidade residual do solo, $\theta_{r}$, pode-se usar

$$
\theta=\theta_{r}+\frac{\theta_{s}-\theta_{r}}{\left\{\ln \left[e+\left(\psi / a_{1}\right)^{n_{1}}\right]\right\}^{m_{1}}}
$$

Outra função bastante utilizada para representar a retenção de água nos solos é a sugerida por van Genuchten (1980):

$$
\theta=\theta_{r}+\frac{\theta_{s}-\theta_{r}}{\left[1+\left(a_{2} \psi\right)^{n_{2}}\right]^{m_{2}}}
$$

onde $a_{2}, n_{2}$ e $m_{2}$ são parâmetros empíricos de ajuste.

\subsubsection{Medida e controle de sucção}

Dada a importância da sucção no solo não saturado, várias técnicas foram desenvolvidas para sua medida e controle. Estas podem ser classificadas em métodos de campo e laboratório, e diferenciadas quanto à parcela de sucção medida. Dentre os métodos de laboratório, encontram-se o de papel filtro, funil de placa porosa e translação de eixos, que foram utilizados nesta pesquisa e serão brevemente apresentados a seguir. Maiores detalhes destas e outras técnicas de medida e controle da sucção podem ser encontradas em Fredlund e Raharjo (1993), Ridley e Burland (1993), Libardi (1995) e Lu e Likos (2004).

\subsubsection{Técnica de papel filtro}

A técnica de papel filtro é normatizada pela ASTM D5298 (2010a) e tem sido bastante utilizada por ser relativamente simples e de baixo custo. Trata-se de uma técnica indireta de medida da sucção do solo por meio da transferência de umidade entre o solo e o papel filtro calibrado. Dependendo do procedimento de ensaio, podem-se medir a sucção matricial, quando 
o papel filtro entra em contato com o solo, ou a sucção total, quando não ocorre o contato direto e o equilíbrio de sucções entre eles se dá por transferência de vapor.

O papel filtro utilizado é o quantitativo do tipo 2, sendo mais comumente usados o Whatman \#42 ou o Schleicher e Schuell \#589. A calibração do papel filtro deve idealmente ser realizada para o papel e o procedimento de laboratório utilizados, no entanto Marinho (1994) relata que as curvas de calibração existentes podem ser usadas para este fim. Alguns exemplos destas curvas podem ser encontrados em ASTM (2010a) e Chandler et al. (1992).

Cabe ainda ressaltar que, apesar de sua simplicidade, esta técnica exige cuidado durante sua execução. Algumas fontes de erros nos ensaios com papel filtro têm sido atribuídas ao procedimento de calibração e ao mau contato entre o papel e a amostra de solo (Power et al. 2008; Marinho e Gomes, 2012).

\subsubsection{Técnica de funil de placa porosa}

Na técnica de funil de placa porosa aplica-se sucção matricial no solo por meio de uma altura negativa de coluna d'água. Isso se faz pelo ajuste da altura de um reservatório, que fica conectado à base do solo por uma placa porosa de alta pressão de entrada de ar e um tubo flexível, ambos saturados. A placa porosa é responsável pela continuidade da água entre o solo e o equipamento. Sua alta pressão de entrada de ar está associada a poros de tamanho bastante reduzidos, que quando saturados impedem o fluxo de ar.

Dois fatores limitam a sucção máxima que se pode atingir neste equipamento: a cavitação, que provoca a descontinuidade da água, e a altura máxima do equipamento, já que esta determina a altura negativa máxima de coluna d'água. Detalhes do equipamento são apresentados por Libardi (1995).

\subsubsection{Técnica de translação de eixos}

O controle ou medida da sucção no solo em ensaios de laboratório tem sido frequentemente feito por meio da técnica de translação de eixos, que foi introduzida por Hilf (1956). O termo translação de eixos se refere ao aumento da pressão no ar dos poros do solo a fim de, mantendo-se a sucção $\left(u_{a}-u_{w}\right)$ constante, elevar o valor da pressão na água para um nível mensurável com transdutores de pressão convencionais, ou seja, maior do que $-1 \mathrm{~atm}$. 
Para pressões de água inferiores, a cavitação torna a fase água descontínua, afetando a precisão das medidas. O emprego da translação de eixos está associado ao uso de placas porosas de alta pressão de entrada de ar, que estabelecem a continuidade da fase água do solo através do sistema de medida ou controle de $u_{w}$. Esta técnica é recomendada para situações nas quais a fase ar do solo é contínua, pois estudos teóricos realizados por Bocking e Fredlund (1980) mostraram que a ocorrência de bolhas de ar ocluso pode superestimar a sucção matricial do solo.

\subsubsection{Estado de tensão}

A sucção no solo não saturado afeta seu estado de tensão devido à tração na água dos poros do solo que tende a aproximar suas partículas e, portanto aumentar a tensão neste contato. Este efeito microscópico tem consequências macroscópicas no comportamento do solo, como na resistência ao cisalhamento, deformabilidade e variação de volume. Algumas tentativas de retratar o efeito da sucção no estado de tensão do solo foram feitas no sentido de reproduzir o princípio de tensões efetivas de Terzaghi (1936) com adaptações para se considerar a sucção. A proposta de Bishop (1959) tem sido a mais utilizada:

$$
\sigma^{\prime}=\left(\sigma-u_{a}\right)+\chi\left(u_{a}-u_{w}\right)
$$

onde $\sigma$ 'é a tensão normal efetiva, $\sigma$ é a tensão normal total e $\chi$ é um parâmetro que depende do grau de saturação, tipo de solo e de efeitos de histerese decorrentes da secagem ou umedecimento do solo. A influência do grau de saturação sobre $\chi$ pode ser observada na Figura 2.5, que reúne dados experimentais de diferentes solos.

Devido a limitações na utilização do conceito de tensões efetivas, principalmente quando se avaliam variações volumétricas no elemento de solo não saturado, o comportamento destes solos tem sido mais frequentemente representado por variáveis de estado de tensão.

Fredlund e Morgenstern (1977) analisaram o equilíbrio entre partículas do solo, água, ar e interface entre ar e água no elemento de solo não saturado e concluíram que qualquer combinação de duas das três variáveis independentes de estado de tensão $\left(\sigma-u_{w}\right),\left(u_{a}-u_{w}\right)$ e $(\sigma$ - $\left.u_{a}\right)$ podem ser usadas para definir o estado de tensão nestes solos. As varáveis $\left(\sigma-u_{a}\right)$ e $\left(u_{a}\right.$ $u_{w}$ ), mostraram-se mais convenientes na análise do comportamento do solo, pois as duas variáveis tem significado físico, além do fato de que $u_{a}$ equivale à pressão atmosférica na maioria das situações convencionais, o que as simplifica. 


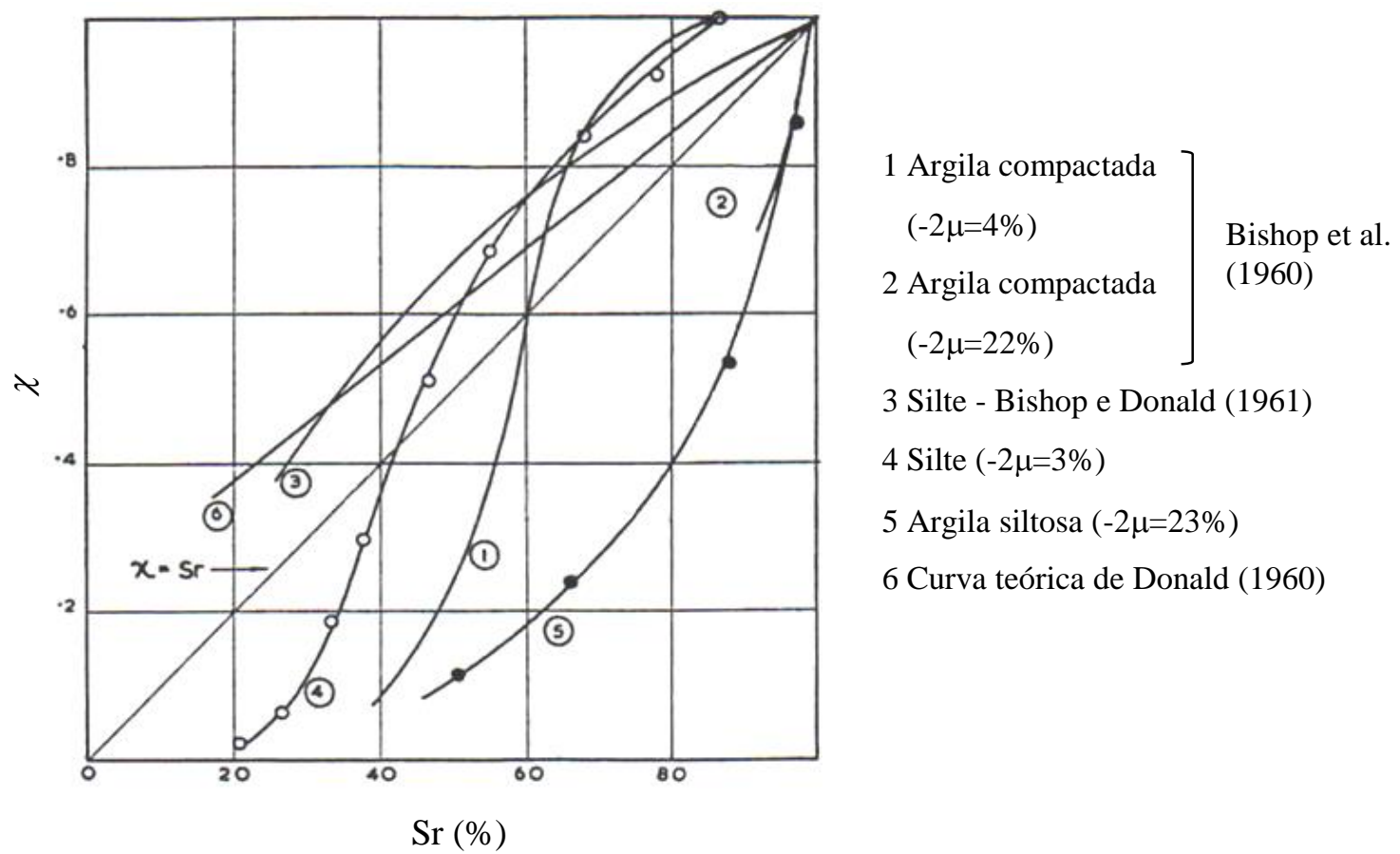

Figura 2.5. Variação do parâmetro $\chi$ com o grau de saturação para vários solos (Jennings e Burland, 1962).

\subsection{RESISTÊNCIA AO CISALHAMENTO}

A resistência ao cisalhamento dos solos é caracterizada pela coesão e o ângulo de atrito entre suas partículas. Quando o solo se encontra em condição saturada, a envoltória de MohrCoulomb é utilizada para o equacionamento da resistência ao cisalhamento

$$
\tau=c^{\prime}+\left(\sigma-u_{w}\right) \operatorname{tg} \phi^{\prime}
$$

sendo $\tau$ a resistência ao cisalhamento, $c^{\prime}$ a coesão efetiva e $\phi^{\prime}$ o ângulo de atrito efetivo. Estando o solo não saturado, a resistência ao cisalhamento conta com um acréscimo devido à sucção do solo. O equacionamento da resistência nestas condições tem sido feito utilizando um conceito de tensões efetivas para solos não saturados, ou com base em variáveis de estado de tensão. No primeiro caso, a expressão de tensão efetiva é utilizada na envoltória de Mohr-Coulomb. Para o uso de variáveis de estado de tensão, Fredlund et al. (1978) sugere uma representação da envoltória de resistência ao cisalhamento na qual cada uma das variáveis contribui independentemente para o acréscimo de resistência: 


$$
\tau=c^{\prime}+\left(\sigma-u_{a}\right) \operatorname{tg} \phi^{\prime}+\left(u_{a}-u_{w}\right) \operatorname{tg} \phi^{b}
$$

onde $\phi^{b}$ é ângulo de atrito interno relativo a sucção.

De acordo com esta proposta, os ângulos $\phi^{b}$ e $\phi$ ' são constantes, resultando em uma envoltória tridimensional planar de resistência, como ilustra a Figura 2.6. Valores experimentais de $\phi^{b}$ para diferentes tipos de solos são apresentados em Fredlund e Rahardjo (1993), enquanto De Campos (1997) reúne dados de solos brasileiros, que são mostrados na Tabela 2.1. Como relatado pelo autor, nela é possível observar a grande faixa de variação do parâmetro $\phi^{b}$, o qual aparentemente independe das características de distribuição granulométrica e de plasticidade dos diferentes solos tropicais considerados.

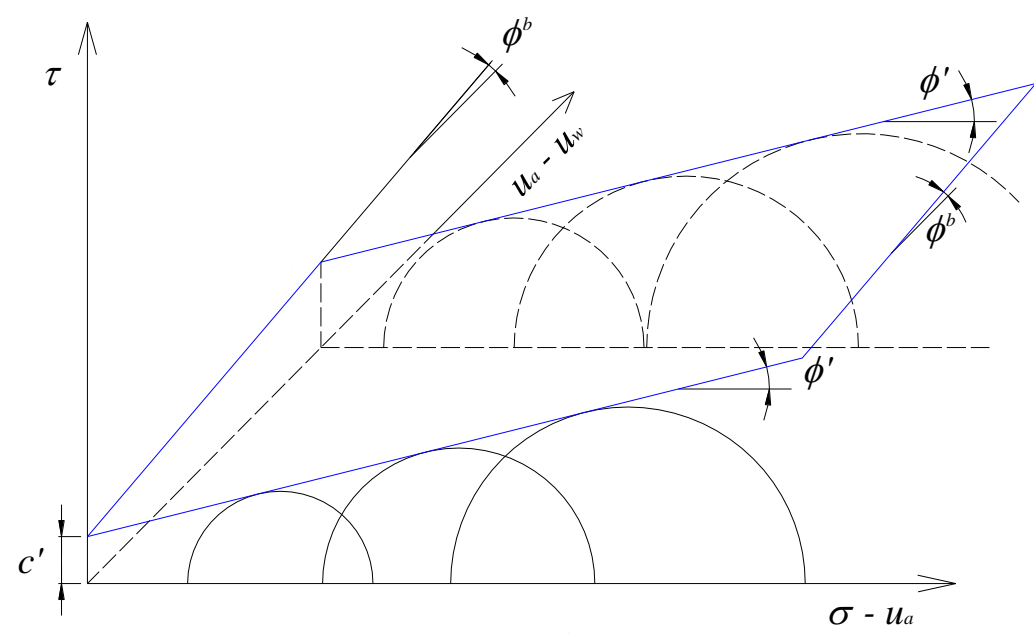

Figura 2.6. Envoltória de ruptura tridimensional para solos não saturados utilizando as variáveis de estado $\left(\sigma-u_{a}\right)$ e $\left(u_{a}-u_{w}\right)$.

Tabela 2.1. Parâmetros de resistência de solos naturais brasileiros não saturados (De Campos, 1997).

\begin{tabular}{|c|c|c|c|c|c|c|c|c|c|}
\hline Material & $e_{i}$ & $\begin{array}{l}S_{r i} \\
(\%)\end{array}$ & $\begin{array}{c}c^{\prime} \\
(\mathrm{kPa})\end{array}$ & $\begin{array}{c}\phi^{\prime} \\
\text { (graus) }\end{array}$ & $\begin{array}{c}\phi^{b} \\
\text { (graus) }\end{array}$ & $\begin{array}{c}\text { Tipo } \\
\text { de } \\
\text { ensaio }\end{array}$ & $\begin{array}{l}\sigma-u_{a} \\
(\mathrm{kPa})\end{array}$ & $\begin{array}{c}u_{a}-u_{w} \\
(\mathrm{kPa})\end{array}$ & Fonte \\
\hline $\begin{array}{c}\text { Residual de } \\
\text { Migmatito } \\
\text { (granítico), } \\
\text { arenoso (IP = } \\
14 \% \text { ) }\end{array}$ & - & - & 0 & 40 & 11,5 & $\begin{array}{c}\text { TCSC- } \\
\text { EM }\end{array}$ & 10 & $\begin{array}{c}10 \mathrm{a} \\
60\end{array}$ & $\begin{array}{c}\text { Abramento } \\
\text { e Carvalho } \\
\text { (1989) }\end{array}$ \\
\hline Colúvio arenoso & - & - & 0 & 38 & 14,4 & & & & \\
\hline $\begin{array}{l}\text { Residual Gnaisse } \\
\text { Kinzigítico - areia } \\
\text { siltosa (NP) }\end{array}$ & 0,91 & 28 & 29,8 & 28,8 & 28,0 & $\begin{array}{c}\text { CDSC- } \\
\text { EM }\end{array}$ & 68 & $\begin{array}{l}50 \mathrm{a} \\
200\end{array}$ & $\begin{array}{c}\text { Fonseca } \\
\text { (1991) }\end{array}$ \\
\hline
\end{tabular}


Tabela 2.1. Parâmetros de resistência de solos naturais brasileiros não saturados (De Campos, 1997). (continuação)

\begin{tabular}{|c|c|c|c|c|c|c|c|c|c|}
\hline $\begin{array}{l}\text { Residual Gnaisse } \\
\text { Kinzigítico - areia } \\
\text { siltosa }(\mathrm{IP}=10 \%)\end{array}$ & 0,76 & 66 & 12,4 & 30,6 & 29,3 & CDSC-EM & 68 & 50 a 200 & $\begin{array}{c}\text { Fonseca } \\
\text { (1991) }\end{array}$ \\
\hline $\begin{array}{l}\text { Colúvio amarelo, } \\
\text { areno-argiloso } \\
(\mathrm{IP}=23 \%)\end{array}$ & 1,18 & 56 & 0 & 26,4 & 6,7 & CDSC-EU & 56 & \multirow{4}{*}{25 a 220} & \multirow{4}{*}{$\begin{array}{c}\text { Carrillo } \\
\text { (1993) }\end{array}$} \\
\hline $\begin{array}{l}\text { Colúvio vermelho, } \\
\text { areno-argiloso } \\
\quad(\mathrm{IP}=17 \%)\end{array}$ & 1,05 & 70 & 11,1 & 26,8 & 5,5 & & 55 & & \\
\hline $\begin{array}{l}\text { Residual de Biotita } \\
\text { Gnaisse, areia } \\
\text { argilo-siltosa } \\
\text { (IP }=18 \%)\end{array}$ & 0,98 & 52 & 8,6 & 30,4 & 6,8 & & 58 & & \\
\hline $\begin{array}{l}\text { Residual de Biotita } \\
\text { Gnaisse, areia } \\
\text { silto-argilosa (NP) }\end{array}$ & 1,13 & 58 & 13,7 & 28,7 & 4,6 & & 53 & & \\
\hline $\begin{array}{l}\text { Residual de } \\
\text { Granulito, argila } \\
\text { silto-arenosa } \\
(\mathrm{IP}=35 \%)\end{array}$ & 1,55 & 56 & 33,3 & 28,4 & 10,3 & \multirow{3}{*}{ CDSC-EM } & \multirow{3}{*}{60} & \multirow{3}{*}{40 a 140} & \multirow{3}{*}{$\begin{array}{l}\text { Fonseca et } \\
\text { al. (1994) }\end{array}$} \\
\hline $\begin{array}{l}\text { Residual de } \\
\text { Granulito, areia } \\
\text { silto-argilosa } \\
(\mathrm{IP}=24 \%)\end{array}$ & 1,88 & 52 & 21,8 & 31,9 & 6,9 & & & & \\
\hline $\begin{array}{l}\text { Residual de } \\
\text { Granulito, areia } \\
\text { argilo-siltosa } \\
(\mathrm{IP}=12 \%)\end{array}$ & 1,16 & 61 & 21,8 & 31,9 & 7,3 & & & & \\
\hline $\begin{array}{l}\text { Solo sedimentar } \\
\text { laterítico, arenoso } \\
\quad(\mathrm{IP}=14 \%)\end{array}$ & 1,0 & 50 & 25,3 & 27,9 & 18,4 & TCSC-EM & 50 & 50 a 250 & $\begin{array}{c}\text { Röhm e } \\
\text { Vilar (1995) }\end{array}$ \\
\hline
\end{tabular}

$e_{i}$ e $S_{r i}$ são respectivamente o índice de vazios e grau de saturação médios dos corpos de prova antes dos ensaios; IP é o índice de plasticidade; CDSC: ensaio de cisalhamento direto com controle de sucção; TCSC: ensaio de compressão triaxial com controle de sucção; EU: estágio único de aplicação de tensão normal ou confinante; EM: estágio múltiplo de aplicação de tensão normal ou confinante.

Embora a envoltória planar seja representativa do comportamento resistente do solo não saturado em determinados intervalos de sucções, o estudo teórico e experimental deste tópico indica que a resistência ao cisalhamento dos solos aumenta de forma não linear com a sucção. 
Do ponto de vista teórico, Fredlund et al. (1987) explicam que para sucções menores do que o valor de entrada de ar, o solo permanece saturado e portanto, os efeitos da pressão na água e da tensão normal na resistência são caracterizados pelo mesmo ângulo de atrito $\phi^{\prime}$. Com o aumento da sucção a partir da entrada de ar, o ar principia a substituir a água nos poros do solo e um aumento adicional na sucção não se mostra tão efetivo no aumento da resistência quanto um aumento na tensão normal líquida, indicando uma redução de $\phi^{b}$ para um valor menor que $\phi^{\prime}$. Experimentalmente, variações de $\phi^{b}$ com o nível de sucção tem sido observadas por vários pesquisadores (Escario e Sáez, 1986; Röhm e Vilar, 1995; Nyunt et al., 2011; entre outros), como exemplifica a Figura 2.7.

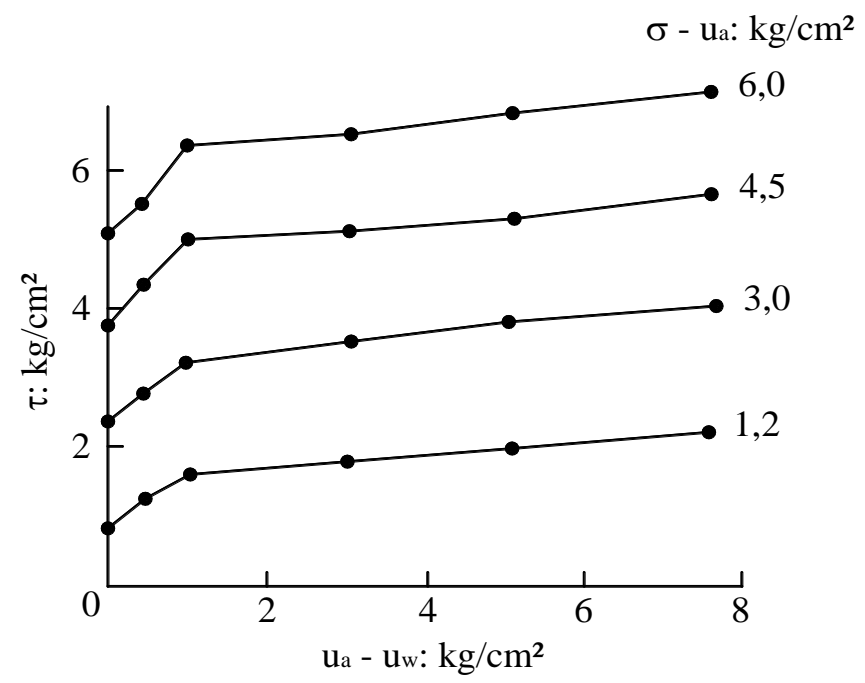

Figura 2.7. Envoltória de resistência não linear em termos de sucção (Escario e Sáez, 1986).

Frente a tais evidências, este comportamento tem sido considerado em diversos modelos de previsão da parcela de resistência do solo devida à sucção, como por exemplo, Vanapalli et al. (1996), Öberg e Sällfors (1997) e Vilar (2007). Estes modelos apoiam-se em dados que são obtidos por meio de práticas rotineiras de laboratório, como os parâmetros efetivos de resistência do solo saturado e a curva de retenção de água, e visam superar dificuldades técnicas e a demanda de tempo requerida em ensaios de resistência com solo não saturados.

\subsubsection{Determinação experimental da resistência}

A determinação experimental da resistência de um solo saturado pode ser feita em laboratório a partir de ensaios convencionais de compressão simples, cisalhamento direto e compressão triaxial. Os mesmos ensaios podem ser utilizados para o solo não saturado, sendo 
que neste caso a sucção é geralmente medida ou controlada. Para isso, é usual o emprego da translação de eixos, cuja utilização implica adaptações nos equipamentos convencionais, sendo necessária a utilização de placas porosa de alta pressão de entrada de ar para impedir o fluxo de ar no sistema de medida de pressões na água. Uma alternativa à translação de eixos é o uso do tensiômetro de alta capacidade, que permite medida direta da pressão na água do solo mesmo para valores inferiores a -1 atm, fazendo uso da elevada resistência à tração da água (Ridley e Burland, 1993).

Especificamente, na execução dos ensaios de compressão triaxial ocorrem as etapas de adensamento, na qual as fases ar e água do solo podem ser drenadas ou não, e de cisalhamento, na qual as pressões de ar e água podem ser medidas ou controladas. A imposição da sucção inicial no solo pode ser feita em etapa prévia ao ensaio ou durante a fase de adensamento. A Tabela 2.2 apresenta um resumo das possíveis configurações de ensaio e as medidas que são realizadas em cada um.

Tabela 2.2. Ensaios de compressão triaxial para solos não saturados (adaptado de Fredlund e Rahardjo, 1993).

\begin{tabular}{|c|c|c|c|c|c|c|}
\hline \multirow{3}{*}{ Métodos de ensaio } & \multirow{3}{*}{$\begin{array}{c}\text { Adensamento } \\
\text { antes da etapa } \\
\text { de cisalhamento }\end{array}$} & \multicolumn{5}{|c|}{ Etapa de cisalhamento } \\
\hline & & \multicolumn{2}{|c|}{ Drenagem } & \multirow{2}{*}{$u_{a}$} & \multirow{2}{*}{$u_{w}$} & \multirow{2}{*}{$\Delta V$} \\
\hline & & $\mathrm{Ar}$ & Água & & & \\
\hline Adensado-drenado (CD) & Sim & $\operatorname{Sim}$ & Sim & $\mathrm{C}$ & $\mathrm{C}$ & M \\
\hline Teor de umidade constante (CW) & Sim & $\operatorname{Sim}$ & Não & $\mathrm{C}$ & $\mathrm{M}$ & M \\
\hline Adensado-não drenado (CU) & Sim & Não & Não & $\mathrm{M}$ & M & --- \\
\hline Não drenado (UU) & Não & Não & Não & --- & --- & --- \\
\hline Compressão simples & Não & Não & Não & --- & --- & --- \\
\hline
\end{tabular}

M: medido, C: controlado.

\subsubsection{Algumas pesquisas recentes sobre resistência ao cisalhamento de solos não saturados por meio de ensaios de compressão triaxial}

A técnica de compressão triaxial tem sido utilizada na avaliação do comportamento tensão $v s$ deformação, variações de volume, e desenvolvimento de sucção no solo durante a ruptura, além da obtenção de envoltórias de resistência ao cisalhamento.

Resultados de ensaios dos tipos CD e CW foram apresentados por Rahardjo et al. (2004), os quais empregaram a técnica de translação de eixos e ensaiaram solo residual compactado 
não saturado. Nas curvas tensão vs deformação observou-se que o aumento da sucção inicial do solo altera gradativamente o formato destas curvas, de modo que quanto maior a sucção, mais distinto foi o pico de resistência. Nos ensaios CW, a sucção ainda apresentou redução com o aumento das deformações axiais, cuja magnitude não esteve relacionada com a sucção inicial dos corpos de prova, segundo os autores. Quanto às deformações volumétricas, notaram-se aumento da tendência à compressão do solo com o aumento da tensão confinante, e nos corpos de prova, dois modos de ruptura foram observados nos ensaios CW: o "embarrigamento" dos corpos de prova com menores sucções e a formação de um plano de ruptura nos demais.

Oliveira (2004) usou um tensiômetro de alta capacidade acoplado ao pedestal de uma câmara triaxial para medida da sucção em ensaios CW e de compressão simples. O autor ensaiou um solo residual de gnaisse compactado e observou menor deformação na ruptura para maiores sucções iniciais de ensaio. No decorrer do cisalhamento, a sucção sofreu redução gradativa com tendência à estabilização após a ruptura. A envoltória de resistência contou com um trecho inicial linear até sucções próximas à entrada de ar, depois disso, funções exponenciais representaram a não linearidade apresentada pelos dados experimentais.

Freitas Neto (2008) realizou ensaios similares em solo laterítico compactado, nos quais observou aumento da resistência e da sucção desenvolvida nos ensaios com o aumento do grau de compactação e a redução do teor de umidade do solo.

Gui e Yu (2008) usaram ensaios CU empregando a técnica de translação de eixos para determinar a resistência de amostras compactadas e indeformadas de um solo laterítico. Os autores obtiveram ângulo de atrito com relação à sucção de $22,7^{\circ}$ e $28,8^{\circ}$ para o solo compactado e indeformado, respectivamente, o que foi associado à destruição da coesão interpartículas no processo de remoldagem.

Nyunt et al. (2011) realizaram ensaios CW em múltiplos estágios em areia e observaram a não linearidade da resistência com relação à sucção. Os autores obtiveram $\phi^{b}$ maior do que $\phi^{\prime}$ para baixas sucções, como reproduzido na Figura 2.8, o que foi atribuído à dilatância do solo.

Patil et al. (2014) ensaiaram uma areia siltosa compactada em ensaios CD. Os autores verificaram a influência da velocidade de deformação durante o cisalhamento e adotaram 0,0086\%/min com base em verificações da diferença de tensões principais e variações de volume. Nestes ensaios foram ainda observadas a tendência a picos de resistência e dilatância dos corpos de prova com o aumento da sucção. 


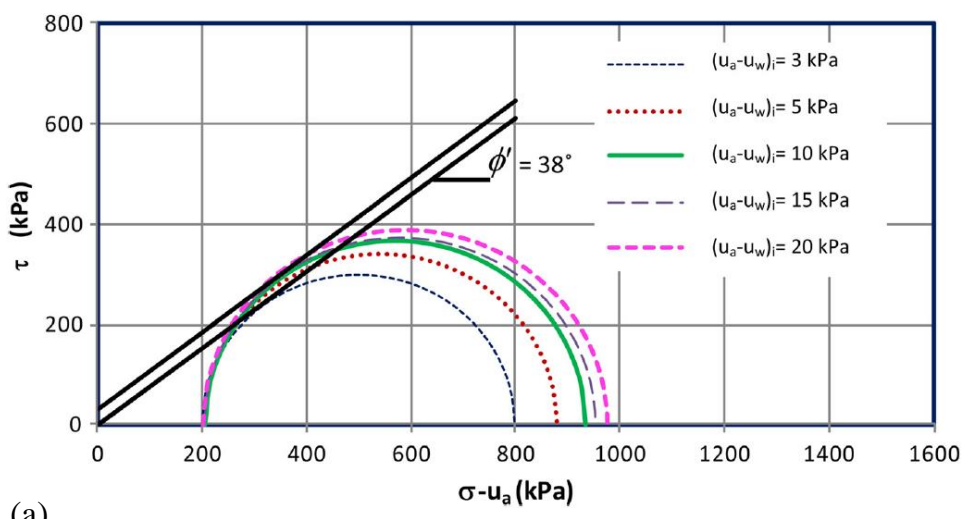

(a)

Figura 2.8.Círculos de Mohr para diferentes sucções e variação do ângulo $\phi^{b}$ com a sucção matricial

(Nyunt et al., 2011).

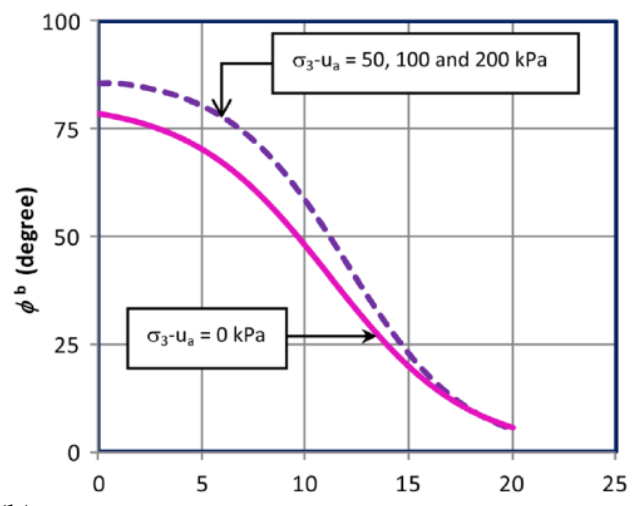

(b)

\subsection{DEFORMABILIDADE}

Em obras geotécnicas é frequente a necessidade de se restringir deformações no maciço de solo para o bom funcionamento de estruturas sobre ele apoiadas. Tais deformações são dependentes do carregamento aplicado ao solo e a relação entre estas grandezas se dá por uma função não linear (Figura 2.9 a).

Tomando a Teoria da Elasticidade, muitas vezes utilizada na simplificação do comportamento de solos, tem-se que o coeficiente angular da curva tensão vs deformação define o módulo de deformabilidade longitudinal ou módulo de Young $(E)$ do material. O módulo é variável com a deformação e pode ser calculado como secante $\left(E_{s e c}\right)$ ou tangente $\left(E_{\text {tan }}\right)$ à curva tensão-deformação. A variação da deformabilidade do solo com o aumento das deformações pode ser observada na Figura 2.9 (b), onde são também representadas faixas de deformações definidas por Atkinson e Sällfors (1991). Nota-se que na região de muito pequenas deformações o módulo de elasticidade é aproximadamente constante, com $E_{t a n}=E_{s e c}$, e corresponde a seu valor máximo ( $E_{o}$ ou $\left.E_{m a ́ x}\right)$. Com isso, tem-se a menor deformabilidade do solo para deformações muito pequenas, que se estendem por um intervalo de deformação nula até um valor $\varepsilon_{o}$, chamado de deformação no limiar do trecho elástico. De $\varepsilon_{o}$ a $1 \%$, na região de pequenas deformações, tem-se o módulo decrescendo rapidamente. Por fim, na região de grandes deformações, a partir de $1 \%$, a deformabilidade do solo torna-se relativamente elevada. No que se refere à deformação $\varepsilon_{o}$, esta aumenta de acordo com a plasticidade dos solos e com o confinamento. Atkinson (2000) apresentou valores típicos de $\varepsilon_{o}$, que compreendem uma faixa de $0,0001 \%$ a $0,01 \%$ para solos não cimentados com plasticidade variando de baixa a alta. 


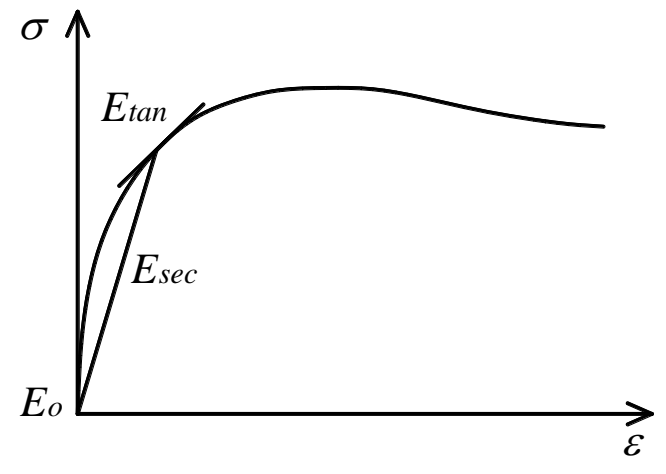

(a)

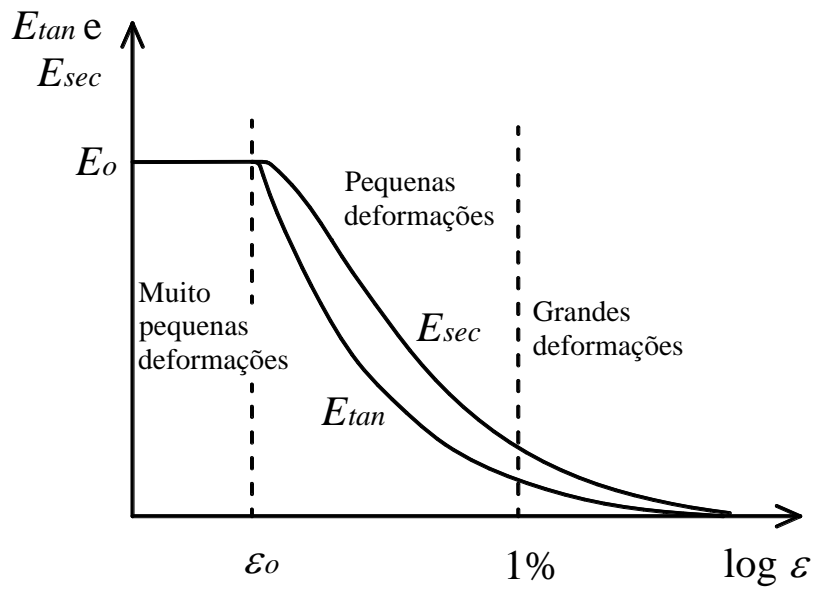

(b)

Figura 2.9. Relação não linear entre (a) tensão e deformação e (b) módulo de deformabilidade e deformação (adaptado de Atkinson, 2000).

Quando a curva tensão-deformação do solo é representada pela tensão cisalhante $(\tau)$ e pela deformação cisalhante $(\gamma)$, o módulo de deformabilidade é representado pelo módulo transversal ou de cisalhamento $(G)$. Este módulo se relaciona diretamente com o módulo de elasticidade longitudinal pela equação:

$$
G=\frac{E}{2 .(1+v)}
$$

onde $G$ é o módulo de deformabilidade de cisalhamento e $v$ é o coeficiente de Poisson.

A relação gráfica entre o módulo e a deformação cisalhante é muitas vezes representada pela relação $G / G_{m a ́ x}$ no eixo das ordenadas, sendo $G_{\text {máx }}$ o módulo de cisalhamento máximo, referente à zona de muito pequenas deformações. A curva resultante desta representação, exemplificada na Figura 2.10, é chamada de curva de degradação do módulo, e sua utilização é conveniente para comparar dados obtidos para diferentes solos e condições.

A determinação da curva de módulo de elasticidade vs deformação é suficiente para a análise da deformabilidade do solo quando os carregamentos são de natureza estática. No entanto, quando as solicitações são de natureza dinâmica, como nos casos de estradas, fundações de máquinas e terremotos, a completa caracterização do comportamento deformacional do solo deve incluir sua característica de amortecimento interno. 


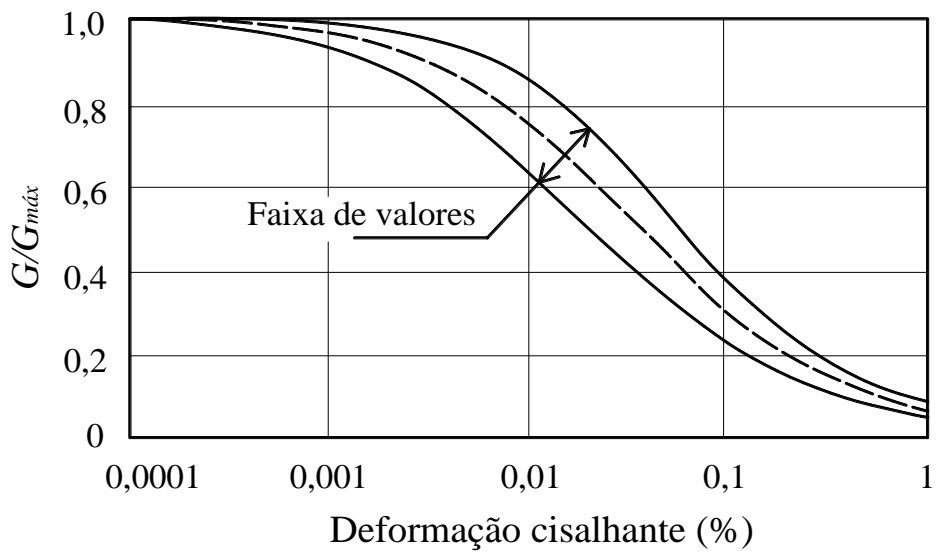

Figura 2.10. Variação de $G / G_{m a ́ x}$ com a deformação cisalhante para areias (Seed e Idriss, 1970).

O amortecimento interno consiste na energia dissipada nos ciclos de carregamento e descarregamento do solo, e é decorrente de seu comportamento visco-elasto-plástico. Tal amortecimento pode ser dividido em duas categorias: amortecimento viscoso e histerético. A primeira é proporcional à velocidade de carregamento, ou frequência de solicitação, e resulta de deformações viscosas. Já a segunda, é função do comportamento tensão-deformação não linear do solo e da amplitude de solicitação, e resulta de deformações plásticas no solo. A caracterização do amortecimento a partir da teoria de oscilação livre com amortecimento pode ser feita pela razão de amortecimento $D$. Este parâmetro representa a relação entre o coeficiente de amortecimento em uma dada condição e o coeficiente de amortecimento crítico:

$$
D=\frac{d}{d_{c}}=\frac{d}{2 \sqrt{k \cdot m}}
$$

onde $D$ é a razão de amortecimento, $d$ é o coeficiente de amortecimento e $d_{c}$ é o coeficiente de amortecimento crítico, $k$ é o coeficiente de mola e $m$ é a massa do sistema submetido à oscilação. A condição de amortecimento crítico, por sua vez, é aquela na qual não ocorrem vibrações, ou seja, quando a massa é retirada do repouso, ela volta à condição de equilíbrio sem oscilações.

A razão de amortecimento do solo, assim como o módulo de elasticidade, varia em função da amplitude de deformações impostas. Na faixa de deformações onde o solo é tomado como elástico, a razão de amortecimento tende a zero e aumenta com o aumento das deformações até um valor máximo.

Quando o carregamento aplicado ao solo é cíclico, a razão de amortecimento é obtida analisando-se as laçadas de histerese que compõem a curva tensão-deformação do solo. $\mathrm{Na}$ Figura 2.11 (a), cada uma das laçadas corresponde a um ciclo de carregamento, sendo que a 
extremidade de cada ciclo corresponde a um ponto da curva básica tensão $v s$ deformação do solo. Para este caso, a razão de amortecimento é definida como a área delimitada pela laçada de histerese normalizada pela energia de deformação elástica:

$$
D=\frac{S_{l}}{2 \pi \cdot G \cdot \gamma_{c}^{2}}
$$

onde $S_{l}$ é a área delimitada pela laçada de histerese e $\gamma_{c}$ é a máxima deformação cisalhante no ciclo. Ainda da laçada de histerese, o módulo de deformabilidade secante pode ser determinado a partir da inclinação da reta que liga as extremidades da laçada (Figura 2.11 b).

(a)

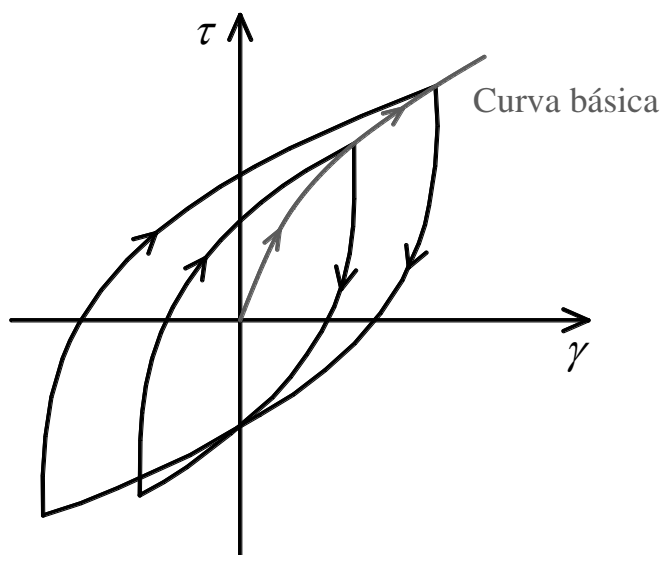

(b)

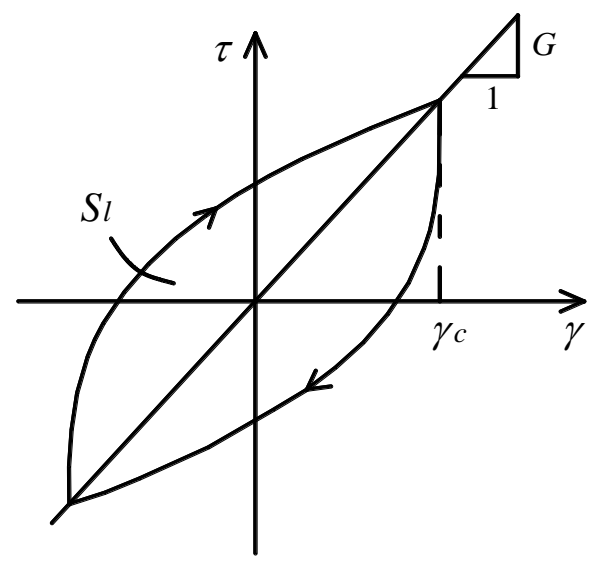

Figura 2.11. Histerese da curva tensão vs deformação devido a solicitações cíclicas no solo.

Outros métodos para determinação da razão de amortecimento se baseiam no decaimento de amplitude em vibrações livres e da resposta de frequência do solo em varreduras de frequências. No caso do decaimento de amplitudes, após provocar uma vibração forçada no solo, permite-se que este vibre livremente até o repouso, como ilustrado na Figura 2.12. O amortecimento é então calculado no domínio do tempo pelo decremento logarítmico do sistema, $\delta$, considerando seu caráter subamortecido:

$$
\begin{gathered}
D=\sqrt{\frac{\delta^{2}}{4 \pi^{2}+\delta^{2}}} \\
\text { onde } \delta=\frac{1}{n} \ln \frac{A_{1}}{A_{n+1}}
\end{gathered}
$$


sendo $n$ o número de ciclos, $A_{l}$ a amplitude de vibração no primeiro ciclo e $A_{n+1}$ a amplitude no ciclo $n+1$.

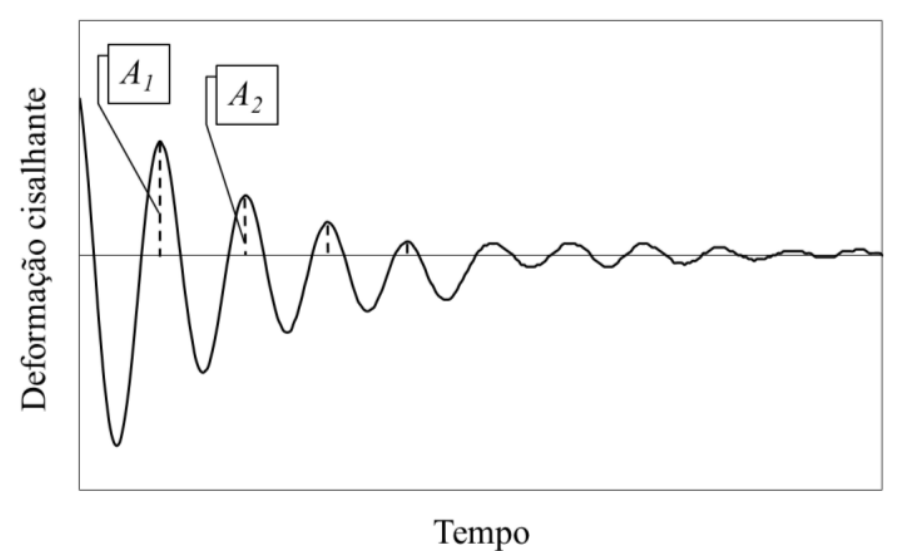

Figura 2.12. Decaimento da amplitude de vibração livre com o tempo.

Já para o cálculo a partir da resposta de frequência, utiliza-se o método da largura de banda (Figura 2.13). O método se baseia na medida da largura da resposta de frequência nas proximidades da ressonância, ou mais especificamente em uma amplitude que é $\sqrt{2}$ vezes a amplitude na ressonância $\left(A_{\text {máx }}\right)$. Esta amplitude é referida como de meia potência e corresponde à uma redução de $3 \mathrm{~dB}$ na amplitude do sinal. A razão de amortecimento é calculada por

$$
D=\frac{1}{2} \frac{f_{2}-f_{1}}{f_{r}}
$$

onde $f_{1}$ e $f_{2}$ são as frequências associadas à $A_{m a ́ x} / \sqrt{2}$, como mostra a Figura 2.13, e $f_{r}$ é a frequência de ressonância (associada à $A_{\text {máx})}$.

Maiores detalhes sobre os métodos de determinação da razão de amortecimento no solo podem ser encontrados em Richart et al. (1970).

A Figura 2.14 mostra faixas de variações da razão de amortecimento com a deformação obtidas por Seed e Idriss (1970) a partir de dados da literatura. Observa-se nesta figura que a razão de amortecimento aumenta substancialmente à medida que a deformação cisalhante cresce a partir de 0,001\%. Razões de amortecimento abaixo dessa deformação são essencialmente constantes e referidas como $D_{\min }$. Pode-se notar também que a razão de amortecimento tende a um valor máximo para deformações muito elevadas.

O módulo de cisalhamento e a razão de amortecimento interno do solo sofrem influência de alguns outros fatores além da já mencionada amplitude de deformação. Entre estes fatores, 
Hardin e Drnevich (1972) relatam como mais significativos para ambos: o estado de tensão, o índice de vazios, o grau de saturação e a razão de sobreadensamento. Especificamente, a razão de amortecimento é ainda influenciada pelo número de ciclos de carregamento.

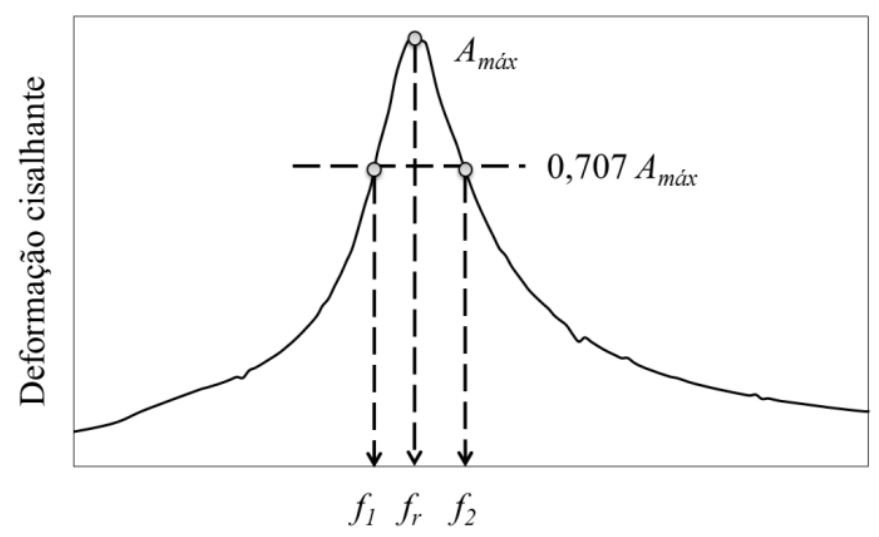

Frequência

Figura 2.13. Cálculo do amortecimento a partir da resposta de frequência.

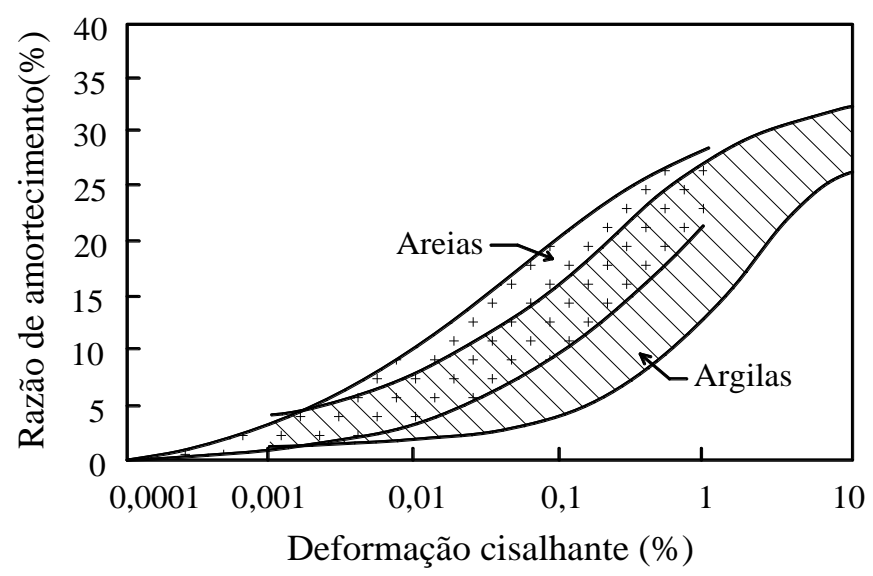

Figura 2.14. Variação da razão de amortecimento com a deformação cisalhante para areias e argilas (Seed e Idriss, 1970)

\subsubsection{Determinação experimental das propriedades deformacionais}

Os métodos disponíveis para determinação das características de deformabilidade dos solos podem ser classificados em ensaios de campo e laboratório. As Tabelas 2.3 e 2.4 apresentam alguns dos diversos tipos de ensaios de campo e laboratório disponíveis e ainda as faixas de deformação empregadas em cada um deles. Estes métodos basicamente utilizam a propagação de ondas de tensão ou deformação no solo para determinação do módulo de 
cisalhamento e da razão de amortecimento interno. Todavia, quando o objetivo do ensaio se restringe à determinação do módulo de elasticidade, é ainda possível a utilização de ensaios de laboratório que fazem uso de solicitações estáticas e definem a curva tensão $v s$ deformação do solo. A partir desta curva, é então obtida a variação do módulo com a evolução das deformações, como foi ilustrado na Figura 2.9. Para que se obtenham dados confiáveis de deformações neste caso, é necessária a utilização de instrumentação adequada, de acordo o nível de deformações impostas ao solo. A Figura 2.15 apresenta graficamente as faixas de deformações que são utilizadas em diferentes técnicas de laboratório, bem como as faixas que rotineiramente ocorrem em estruturas geotécnicas.

Tabela 2.3. Ensaios de campo mais utilizados para determinação do módulo de cisalhamento dos solos (Barros e Hachich, 1998).

\begin{tabular}{lcc}
\hline \hline Ensaios & Princípio da técnica & $\begin{array}{c}\text { Faixa de deformação para a } \\
\text { qual } G \text { pode ser medido (\%) }\end{array}$ \\
\hline $\begin{array}{l}\text { Crosshole } \\
\text { Downhole } \\
\text { Uphole }\end{array}$ & $\begin{array}{c}\text { Determinação da velocidade de } \\
\text { propagação da onda de } \\
\text { cisalhamento } V_{s}\end{array}$ \\
$\begin{array}{l}\text { Piezocone sísmico } \\
\text { Refração sísmica }\end{array}$ & $\sim 10^{-4}$ \\
$\begin{array}{l}\text { Vibração em regime } \\
\text { estacionário }\end{array}$ & $\begin{array}{c}\text { Determinação da velocidade de } \\
\text { propagação da onda Rayleigh } \\
\text { Análise espectral de ondas } \\
\text { superficiais (SASW) }\end{array}$ & $\begin{array}{c}V_{r} \\
\text { Ensaio pressiométrico }\end{array}$ \\
& $\begin{array}{c}\text { Determinação da curva tensão- } \\
\text { deformação (laçadas de } \\
\text { histerese) }\end{array}$ \\
\hline \hline
\end{tabular}

As técnicas de laboratório apresentam algumas vantagens quando comparadas às técnicas de campo. Dentre elas estão a possibilidade de análise da influência de fatores como tensão de confinamento e sucção, o controle das condições de contorno durante os ensaios e o fato de algumas das técnicas serem não destrutivas, de modo que uma mesma amostra possa ser submetida a vários ensaios. Além disso, mesmo para pequenas deformações, se estas forem medidas com alta precisão em amostras representativas submetidas a tensões de confinamento apropriadas, os ensaios de laboratório fornecem medidas consistentes da deformabilidade do solo em campo (Burland, 1989). 
Tabela 2.4. Ensaios de laboratório mais utilizados para determinação do módulo de cisalhamento e da razão de amortecimento dos solos (Barros e Hachich, 1998).

\begin{tabular}{lcc}
\hline \hline Ensaios & Princípio da técnica & $\begin{array}{c}\text { Faixa de deformação para a } \\
\text { qual } G \text { pode ser medido }(\%)\end{array}$ \\
\hline $\begin{array}{l}\text { Coluna ressonante } \\
\text { Bender elements }\end{array}$ & $\begin{array}{c}\text { Determinação da velocidade da } \\
\text { onda de cisalhamento } V_{s}\end{array}$ & $10^{-4}$ a $10^{-2}$ \\
\hline $\begin{array}{l}\text { Cisalhamento simples cíclico } \\
\text { Triaxial cíclico }\end{array}$ & $\begin{array}{c}\text { Determinação da curva tensão- } \\
\text { deformação (laçadas de } \\
\text { histerese) }\end{array}$ & $10^{-4}$ \\
Torcional cíclico & $\begin{array}{c}\text { Determinação de } V_{s} \text { (coluna } \\
\text { ressonante) e laçadas de } \\
\text { histerese (torcional cíclico) }\end{array}$ & $10^{-4}$ a 1 \\
$\begin{array}{l}\text { Coluna ressonante e torcional } \\
\text { cíclico combinados }\end{array}$ & & \\
\hline \hline
\end{tabular}

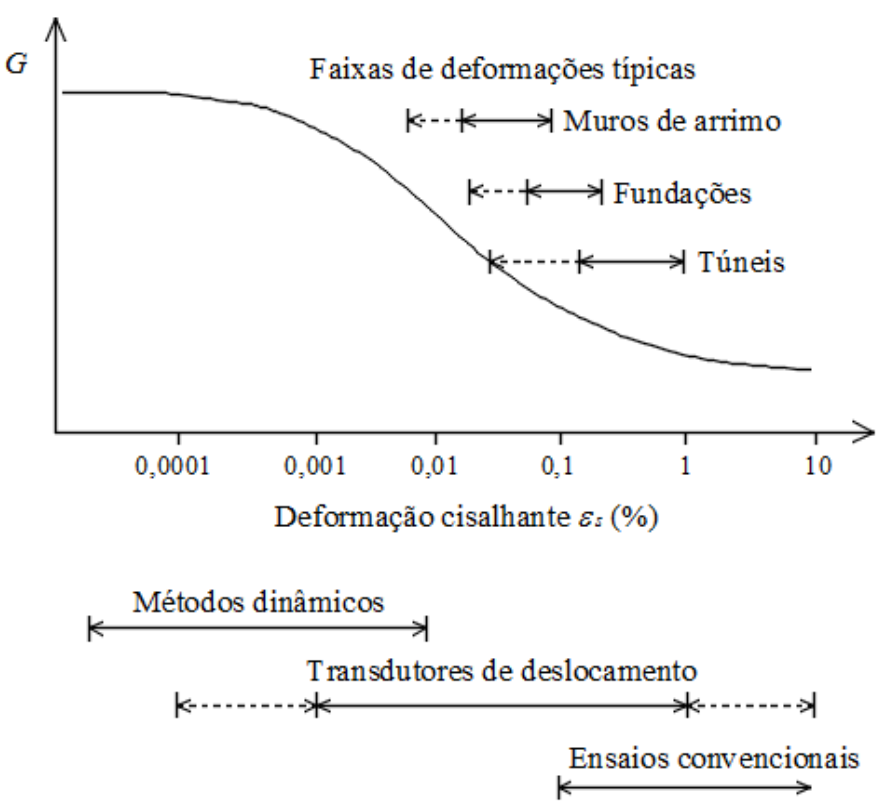

Figura 2.15. Faixas de deformações típicas para ensaios de laboratório e estruturas geotécnicas (adaptado de Atkinson, 2000).

Dentre os ensaios de laboratório, o de coluna ressonante é o que tem sido mais amplamente utilizado na avaliação do módulo de deformabilidade e da razão de amortecimento para baixas e moderadas amplitudes de deformação no solo (Barros e Hachich, 1998). Este método, normatizado pela ASTM D4015 (2007), consiste na aplicação de certa frequência de vibração senoidal ao corpo de prova, sendo que esta vibração pode ser longitudinal ou torcional. No decorrer do ensaio, a frequência de vibração aplicada ao solo é alterada até que se iguale à frequência de ressonância do sistema solo-equipamento. A partir da condição de ressonância são calculados o módulo e a deformação cisalhante do solo. Quando a excitação do sistema é 
interrompida, a razão de amortecimento pode ser determinada pelo decaimento da amplitude de deformações em vibração livre, por exemplo. Aplicando ao corpo de prova diferentes amplitudes de vibração é possível obter as curvas de módulo vs deformação e razão de amortecimento vs deformação do solo. Uma descrição mais detalhada do equipamento de coluna ressonante e de procedimentos gerais de ensaio são encontrados em Barros e Hachich (1998) e ASTM (2007).

Quando a finalidade do ensaio de laboratório é a determinação do módulo de deformabilidade máximo do solo, o uso da técnica de bender elements tem sido crescente (Brocanelli e Rinaldi, 1998). Este método utiliza solicitações dinâmicas para determinar as características dos solos na faixa de muito pequenas deformações. Sua principal vantagem está na simplicidade de execução e interpretação dos resultados. Além disso, os bender elements são versáteis, à medida que podem ser instalados em cabeçotes e pedestais de equipamentos de laboratório como compressão triaxial, cisalhamento direto e adensamento (Figura 2.16).

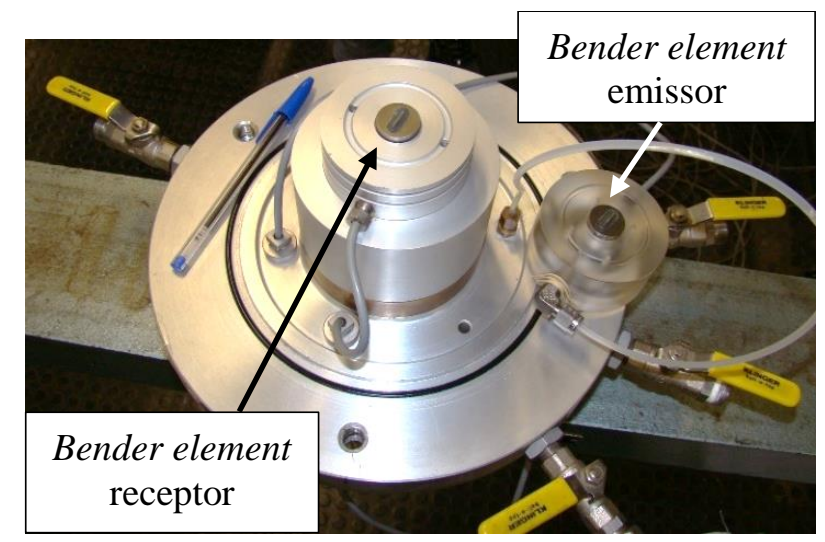

Figura 2.16. Bender elements acoplados a cabeçote e pedestal de câmara triaxial.

Os bender elements são pequenas placas retangulares piezo-cerâmicas que sofrem flexão quando excitadas por pulsos elétricos ou, geram pulsos elétricos quando fletidas. Um comprimento de 3 a $9 \mathrm{~mm}$ desses elementos fica em balanço, para que sejam inseridos no interior do solo durante os ensaios. Os bender elements trabalham em pares, sendo um elemento transmissor de onda e outro receptor, e são posicionados em faces opostas do corpo de prova. Para a execução dos ensaios (Figura 2.17), geradores de pulso e de função alimentam o elemento transmissor com uma voltagem, o que provoca sua flexão e a emissão de uma onda de cisalhamento através do solo. A chegada da onda ao elemento receptor movimenta-o gerando por sua vez uma pequena voltagem. As ondas transmitidas e recebidas são captadas e exibidas 
por um osciloscópio, que é conectado a um computador. O tempo decorrido entre a emissão e recepção do sinal é então utilizado na determinação da velocidade da onda no solo.

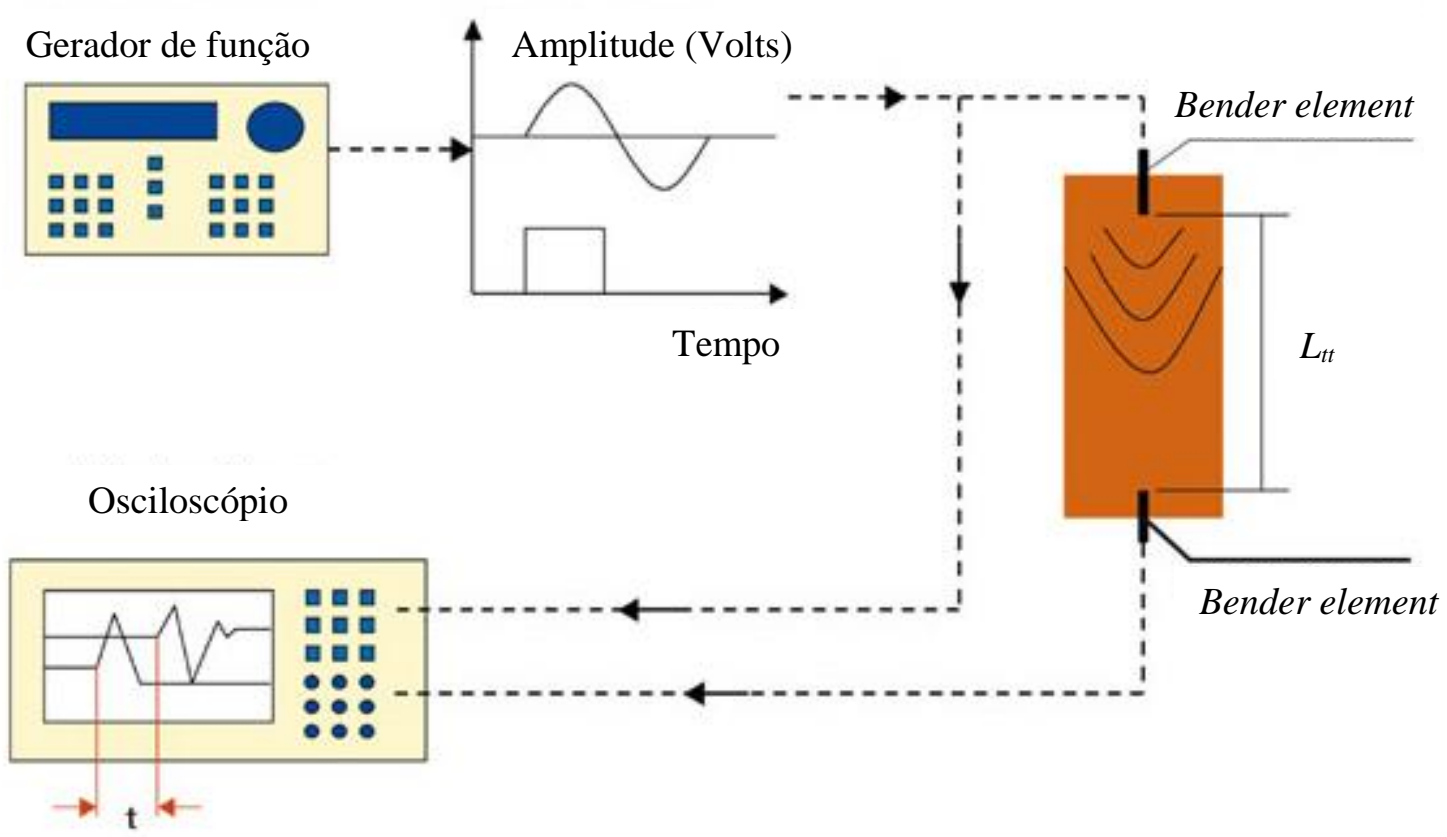

Figura 2.17. Esquema de execução de ensaio com bender elements (Wykeham Farrance/Controls

Group).

O cálculo da velocidade da onda de cisalhamento que atravessa o solo considera que o comprimento percorrido por ela corresponda à distância entre as extremidades do elemento transmissor e receptor (Viggiani e Atkinson, 1995; Dyvik e Madshus, 1985), e ainda que o tempo decorrido neste percurso seja dado pelo intervalo entre a emissão e recepção da onda. Assim, a relação entre estas duas grandezas fornece a velocidade de propagação da onda de cisalhamento no interior do solo. Considerando que o solo se comporte como um material elástico a muito pequenas deformações, o módulo de cisalhamento máximo pode ser calculado por

$$
G_{\text {máx }}=\rho V_{s}^{2}=\rho\left(L_{t t} / t\right)^{2}
$$

onde $\rho$ é a massa específica do solo e $V_{s}$ é a velocidade de propagação da onda de cisalhamento.

Além da determinação do módulo de cisalhamento máximo, recentemente este equipamento tem sido utilizado para medida da razão de amortecimento mínimo do solo, que está associada a muito pequenas deformações (Brocanelli e Rinaldi, 1998; Takkabutr, 2006; Karl, et al., 2008). Neste caso, semelhante ao que ocorre no ensaio de coluna ressonante, busca- 
se a frequência de ressonância do solo. Para isso, propaga-se no solo um sinal com frequência constante de ondas cujas amplitudes são captadas pelo elemento receptor. Este procedimento é repetido até que seja definido o espectro de resposta do solo, isto é, a curva amplitude $v s$ frequência. Deste modo, pode-se calcular a razão de amortecimento mínimo por dois métodos que fazem uso de equacionamento simples, o de largura de banda e ajuste do círculo (Ewins, 1988).

\subsubsection{Interpretação dos ensaios com bender elements}

Apesar da simplicidade de execução e cálculo de ensaios com bender elements, sua interpretação tem sido discutida, principalmente no que se refere à determinação do tempo de percurso da onda no solo. A subjetividade desta interpretação tem sido associada a erros nos valores de $t$ e consequentemente, $G_{m a ́ x}$. Diversos métodos no domínio do tempo e da frequência têm sido usados para inferir o tempo $t$, como o tempo decorrido entre a emissão da onda e a primeira maior deflexão do sinal recebido, o pico do sinal emitido e o primeiro maior pico do sinal recebido, a correlação cruzada destes sinais e o método do espectro de frequência cruzada. Todavia, ainda não há na literatura um consenso dos pesquisadores sobre qual é o método mais confiável (Viggiani e Atkinson, 1995; Leong et al., 2005; Chan, 2010).

Outro aspecto importante sobre a determinação do tempo de percurso da onda é a qualidade dos sinais recebidos. Estes sinais são afetados por interferências (near-field effects), que podem ser minimizadas pela escolha de altas frequências de excitação para os pulsos emitidos. A razão entre distância percorrida pela onda $\left(L_{t t}\right)$ e seu comprimento $(\lambda)$ pode ser usada como guia para a seleção da frequência de emissão do pulso, sendo que o comprimento da onda pode ser estimado da relação entre a sua velocidade e a frequência da onda emitida. Sanchez-Salinero et al. (1986) mostraram numericamente que as interferências são insignificantes quando $L_{t} / \lambda$ é maior que 2. Já em investigações experimentais, Jovičić et al. (1996) confirmaram esta tendência, enquanto Leong et al. (2005) concluíram que $L_{t} / \lambda$ de pelo menos 3,33 é razoável para melhorar a qualidade do sinal recebido. 


\subsubsection{Algumas pesquisas recentes sobre deformabilidade de solos não saturados por meio de ensaios de bender elements, compressão triaxial e coluna ressonante}

Dentre as técnicas de ensaio para determinação das propriedades deformacionais de solos em laboratório, a de bender elements tem ganhado destaque nas pesquisas com solos não saturados por ser relativamente recente e ainda, bastante versátil. É também frequente a comparação de resultados desta com outras técnicas de ensaio, como a de coluna ressonante. Ensaios de coluna ressonante e compressão triaxial com instrumentação interna têm sido utilizadas para se avaliar variações da deformabilidade em uma faixa mais ampla de deformações.

Mancuso et al. (2002) ensaiaram uma areia siltosa compactada em coluna ressonante com controle de sucção. As sucções de ensaio foram induzidas pela compactação e atingiram até $400 \mathrm{kPa}$. Os autores verificaram um formato sigmoide para a relação entre $G_{m a ́ x}$ e a sucção, sendo que as maiores alterações em $G_{m a ́ x}$ foram notadas para sucções até $200 \mathrm{kPa}$, com tendência a um valor limite depois disso, que dependeu da tensão de confinamento.

Leong et al. (2006) examinaram o efeito da sucção matricial e da pressão confinante na relação entre o módulo de cisalhamento e a deformação de um solo residual compactado a partir de ensaios triaxiais não drenados, utilizando bender elements e instrumentação interna de deformações. Os dados experimentais obtidos foram ajustados pela equação de Borden et al. (1996) e analisando os parâmetros de ajuste da equação, os autores concluíram que tanto a sucção quanto o confinamento afetam o valor de $G_{\text {máx }}$ do solo, no entanto, a sucção matricial inicial tem efeito significativo na curva como um todo, enquanto a influência da pressão confinante pode ser representada por alterações em $G_{\text {máx }}$.

Takkabutr (2006) investigou a influência da pressão confinante $\left(\sigma_{0}\right)$ e da sucção induzida por compactação nas propriedades deformacionais do solo a muito pequenas deformações e ainda relacionou o módulo de cisalhamento com estes fatores por equações empíricas. O estudo foi conduzido utilizando as técnicas de bender elements e coluna ressonante. As Figuras 2.18 e 2.19 ilustram os resultados obtidos para uma areia sob confinamento isotrópico, nas quais são mostrados ajustes por correlações propostas pelo autor. Nestas figuras, o módulo de cisalhamento e a razão de amortecimento normalizados correspondem respectivamente a $G_{m a ́ x} / \sigma_{\mathrm{o}}(\mathrm{kPa} / \mathrm{kPa})$ e $D_{m i n} / \sigma_{\mathrm{o}}(\% / \mathrm{kPa})$. Notou-se na Figura 2.18 que o nível de confinamento teve um efeito significativo na deformabilidade deste solo e que a sucção induzida por compactação contribuiu com o aumento de $G_{m a ́ x}$. Do mesmo modo ocorreu um decréscimo contínuo na razão de amortecimento mínimo com o aumento da sucção (Figura 2.19), que foi atribuído ao 
aumento de tensões efetivas devido às pressões negativas na água. Observou-se ainda certa dispersão de resultados quando se compararam os métodos de coluna ressonante e bender elements.

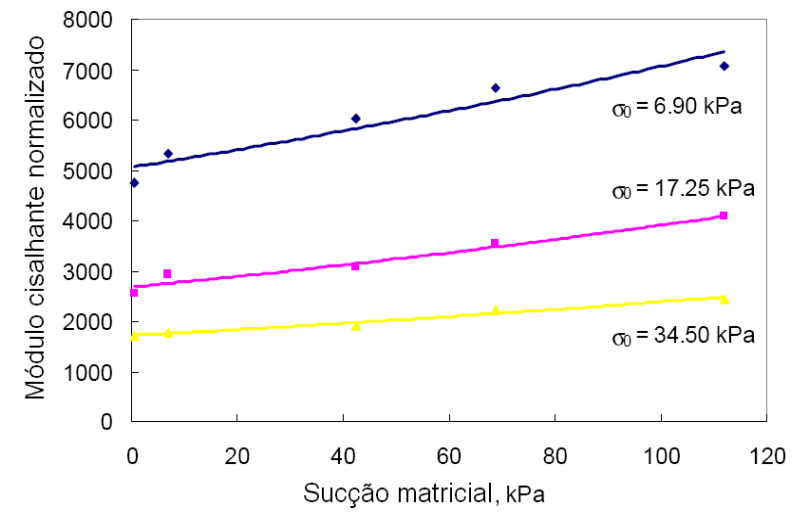

(a)

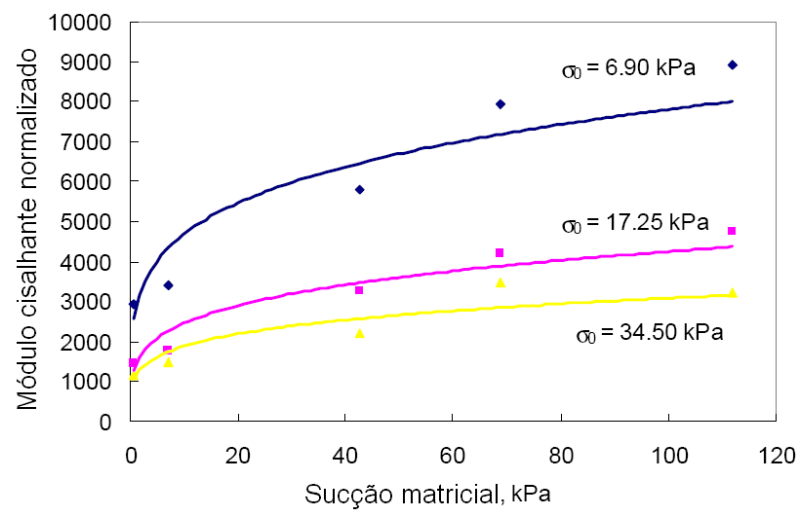

(b)

Figura 2.18. Módulos de cisalhamento normalizados obtidos de (a) ensaios de coluna ressonante e (b) bender elements para uma areia mal graduada (Takkabutr, 2006).

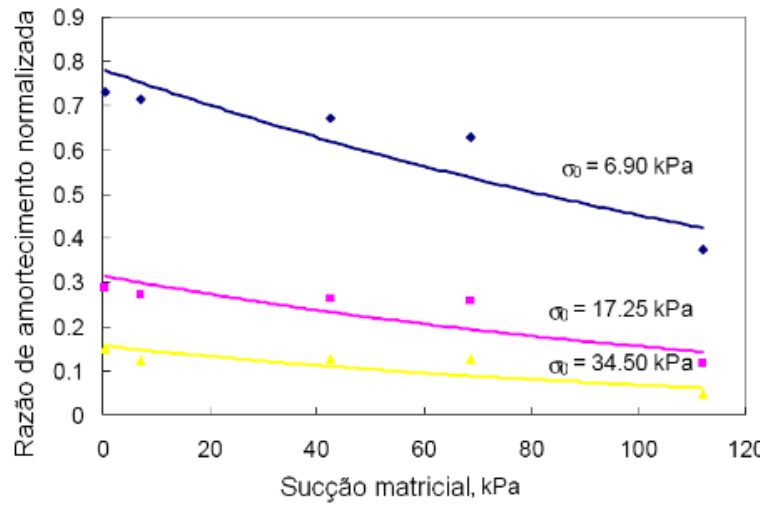

(a)

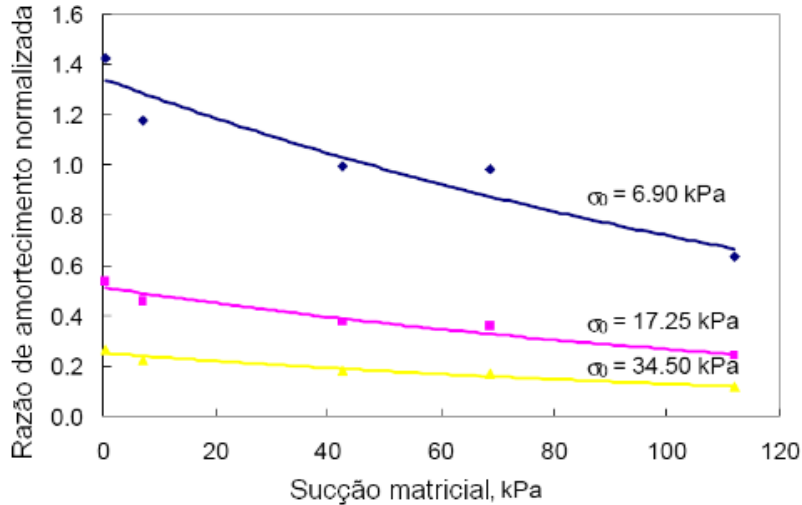

(b)

Figura 2.19. Razões de amortecimento normalizadas obtidas de (a) ensaios de coluna ressonante e (b) bender elements para uma areia mal graduada (Takkabutr, 2006).

Florez (2010) utilizou uma coluna ressonante com controle de sucção e bender elements para ensaiar uma areia siltosa. A comparação dos valores de módulo de cisalhamento máximo obtidos por ambas as técnicas indicou que os resultados de bender elements superestimam ligeiramente os valores de $G_{m a ́ x}$.

Nyunt et al. (2011) utilizaram bender elements em ensaios triaxiais com confinamento isotrópico em areia compactada e verificaram que a relação de $G_{m a ́ x}$ com a tensão confinante tem tendência similar no solo saturado e não saturado. No que se refere à relação de $G_{m a ́ x}$ com 
a sucção, esta foi não linear e o módulo aumentou a uma taxa de cerca de $40 \%$ para sucções abaixo da entrada de ar, e cerca de $15 \%$ para valores acima disso.

Ng e Xu (2012) obtiveram maiores magnitudes de módulo de cisalhamento para maiores sucções nas deformações entre $0,001 \%$ e $1 \%$ em ensaios de compressão triaxial com transdutores locais de deslocamento e bender elements. Entretanto, para a curva $G / G_{m a ́ x}$ a redução do módulo foi desprezível para deformações maiores que $0,02 \%$. A sucção também foi responsável por aumentos de $G_{m a ́ x}$, deformação no limiar do trecho elástico e da taxa de redução do módulo de cisalhamento, o que foi atribuído ao efeito dominante do menisco de água quando o índice de vazios, o grau de saturação e o teor de umidade decrescem.

Madhusudhan e Kumar (2013) realizaram ensaios de coluna ressonante em areias, examinando o efeito do grau de saturação na razão de amortecimento mínimo. Foi observada a diminuição contínua de $D_{\min }$ com o aumento da densidade relativa e do confinamento efetivo. Além disso, esta propriedade atingiu os maiores valores para o solo saturado, independentemente do tamanho dos grãos do solo. O efeito da saturação gradual do solo, a partir de condições iniciais em que ele se encontrava praticamente seco, foi provocar variações do amortecimento entre 0,5 e $1 \%$.

Esta síntese dos trabalhos que estão associados diretamente ao tema desta pesquisa sobre a medida de deformabilidade em solos não saturados, e, mais especificamente, sua medida em uma faixa de muito pequenas deformações, é um tema bastante atual e que demanda aprofundamento, especialmente para solos com características peculiares, como os tropicais.

\subsubsection{Deformabilidade dos solos tropicais}

As propriedades dinâmicas de solos tropicais têm sido estudadas em Geotecnia através de ensaios de campo e laboratório. Técnicas de campo têm sido mais exploradas à medida que avançam na obtenção de dados de resistência e deformabilidade em um único ensaio, como em Rocha (2013), por exemplo. Já em laboratório, avanços foram feitos na década de 1990 com o uso de coluna ressonante (Giacheti, 1991; Barros, 1997). Tais estudos mostraram o comportamento diferenciado dos solos tropicais em relação aos solos de clima temperado, cuja disponibilidade de dados é mais abundante na literatura (Seed e Idriss, 1970; Borden et al.,1996; Mancuso et al., 2002; Leong et al., 2006; entre outros).

Tratando particularmente dos solos tropicais sujeitos à laterização, Barros et al. (1991) apresentam resultados de ensaios em coluna ressonante que indicam que estes solos apresentam 
valores de módulo de cisalhamento e razão de amortecimento que são até $230 \%$ superiores aos estimados por expressões empíricas propostas com base no comportamento de solos de clima temperado, como ilustrado na Figura 2.20. Ainda, Barros (1997) verificou que a degradação do módulo nos solos lateríticos é mais acentuada em comparação aos solos de clima temperado. Tais diferenças foram em parte atribuídas às características genéticas dos solos lateríticos. Um outro fator que diferencia os solos tropicais dos de clima temperados é a frequente ocorrência da condição não saturada, cuja influência não foi diretamente pesquisada pelos referidos autores mas que é alvo de investigação nesta tese.

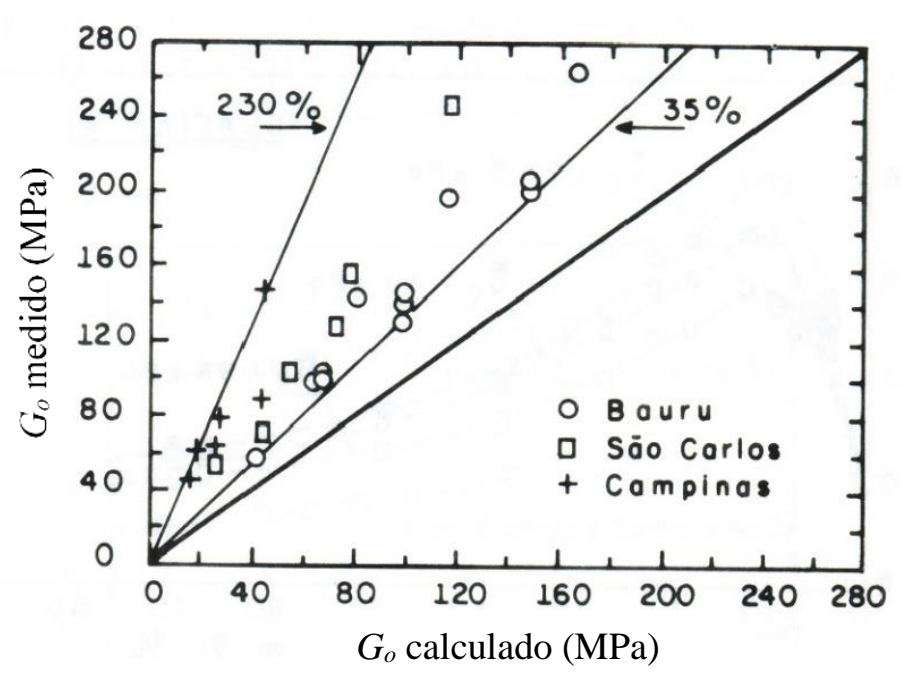

Figura 2.20. Comparação dos valores de módulo de cisalhamento máximo $\left(G_{o}\right)$ medidos em coluna ressonante e calculados por correlações empíricas (Barros et al., 1991). 


\section{PROGRAMA EXPERIMENTAL}

O programa experimental desta pesquisa envolveu séries de ensaios de deformabilidade e resistência ao cisalhamento, que foram realizados com solo compactado e indeformado, saturado e não saturado. Os fluxogramas na Figura 3.1 apresentam a relação dos ensaios realizados para cada condição da amostra, juntamente com os dados obtidos em cada um deles.

Os ensaios com solo compactado foram principalmente realizados com corpos de prova preparados no teor de umidade ótimo. Adicionalmente, utilizaram-se teores de umidade nos ramos seco e úmido da curva de compactação Proctor normal para análises complementares, considerando o teor de umidade de compactação como variável. 

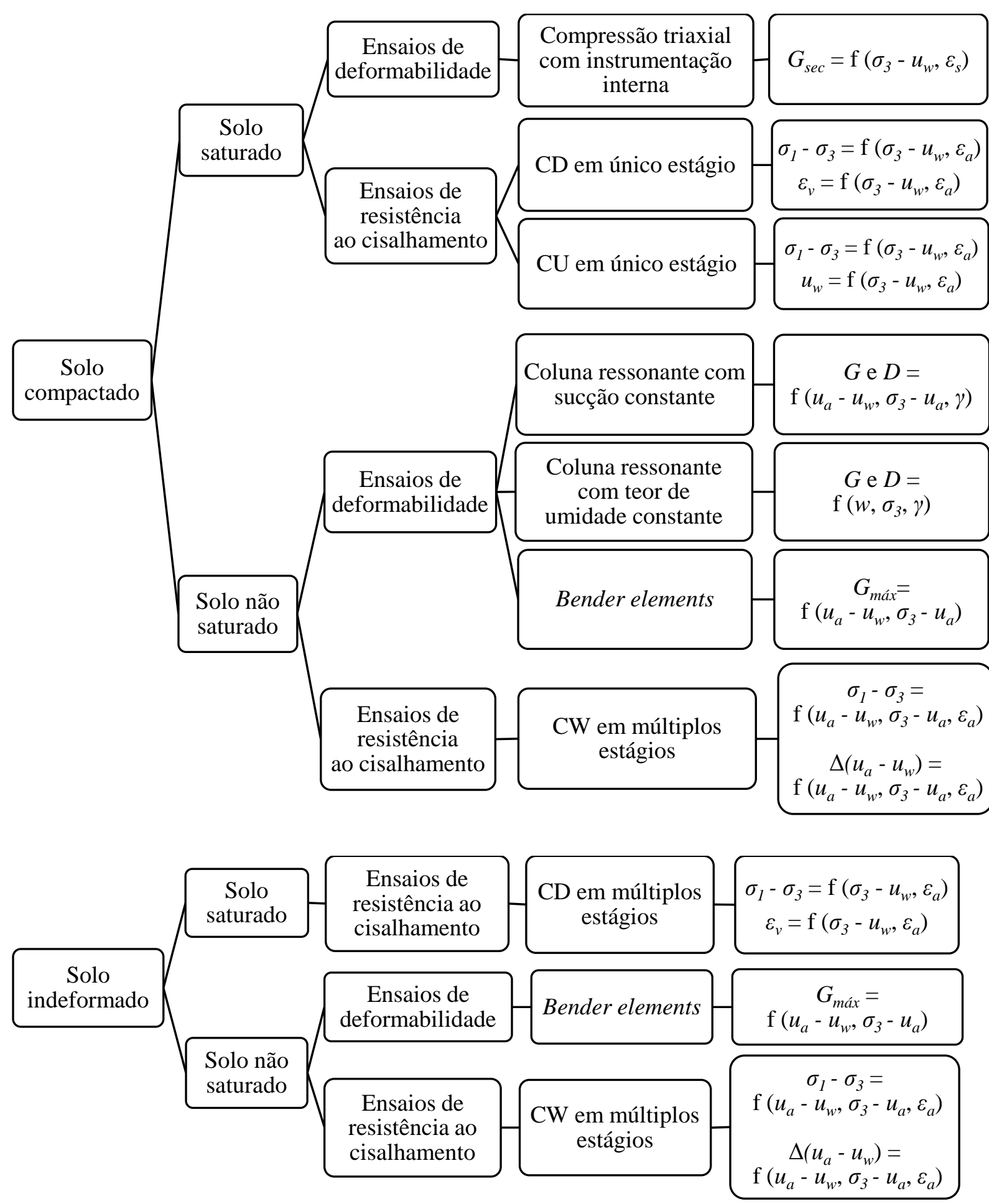

CD, CU e CW significam respectivamente adensado-drenado, adensado-não drenado e com teor de umidade constante, $D$ é a razão de amortecimento, $G$ é módulo de cisalhamento, $G_{m a ́ x}$ é o módulo de cisalhamento máximo, $G_{s e c}$ é o módulo de cisalhamento secante, $w$ é o teor de umidade, $\gamma$ é a deformação cisalhante, $u_{w}$ é a pressão neutra, $\left(u_{a}-u_{w}\right)$ é a sucção, $\Delta\left(u_{a}-u_{w}\right)$ é a variação de sucção, $\varepsilon_{a}$ é a deformação axial, $\varepsilon_{s}$ é a deformação cisalhante da compressão triaxial, $\varepsilon_{v}$ é a deformação volumétrica, $\sigma_{3}$ é a tensão confinante, $\left(\sigma_{1}-\sigma_{3}\right)$ é a diferença de tensões principais, $\left(\sigma_{3}-u_{w}\right)$ e $\left(\sigma_{3}-u_{a}\right)$ são respectivamente as tensões confinantes líquidas para o solo saturado e não saturado.

Figura 3.1. Fluxograma do programa experimental. 


\section{MÉTODOS EXPERIMENTAIS}

\subsection{SOLO ESTUDADO}

O programa experimental utilizou solo de origem sedimentar cenozóica, formado pelo retrabalhamento dos materiais do Grupo Bauru e das Formações Serra Geral e Botucatu. Na região, estes sedimentos encontram-se sobre arenitos da Formação Itaqueri, Grupo Bauru. Amostras deformadas e indeformadas deste solo foram coletadas no Campus 2 da Universidade de São Paulo em São Carlos entre as profundidades de 0,7 e 1,0 m, e com teor de umidade de aproximadamente $16 \%$.

Trata-se de um solo arenoso coluvionar submetido ao processo de laterização, que é típico de regiões de clima tropical. Nogami e Villibor (1995) relatam que os solos superficiais de comportamento geotécnico laterítico são constituídos predominantemente de minerais resistentes ao intemperismo, como quartzo, caolinita, óxidos e hidróxidos de ferro e alumínio. Quanto à estrutura, é comum a ocorrência de macrofábrica homogênea e elevada porosidade aparente.

Dando início ao programa experimental, os ensaios de caracterização do solo compreenderam análise granulométrica conjunta, massa específica dos sólidos e limites de liquidez e plasticidade. Tanto os ensaios de caracterização como o ensaio de compactação seguiram as normas da Associação Brasileira de Normas Técnicas (ABNT). Para identificar o comportamento laterítico do solo, a amostra foi submetida ainda aos ensaios de compactação mini-MCV (Moisture Condition Value) e perda de massa por imersão, para posterior classificação pela MCT (Miniatura, Compactado, Tropical) (Nogami e Villibor, 1979).

$\mathrm{O}$ solo foi caracterizado quanto à retenção de água em trajetória de drenagem por meio de ensaios de funil de placa porosa e papel filtro.

Para um entendimento mais completo do comportamento deste solo, principalmente no que se refere às características de retenção de água, ensaios de porosimetria por intrusão de mercúrio foram realizados em amostras compactadas. Para a porosimetria da amostra indeformada, utilizaram-se resultados de Fernandes (2011). 


\subsection{CORPOS DE PROVA}

Amostras deformadas foram secas e quarteadas em laboratório, e após ajuste de umidade os corpos de prova foram compactados em camadas de $2 \mathrm{~cm}$ de espessura, utilizando-se um molde cilíndrico bipartido. A compactação foi do tipo dinâmica, aplicando-se a quantidade de golpes necessária para atingir a densidade desejada. A Figura 4.1(a) ilustra o equipamento utilizado. Buscou-se atingir grau de compactação de 95\% na energia Proctor normal e teores de umidade que variaram entre 11,2 e 18,9\%. O teor de umidade de compactação foi ajustado em média com dois dias de antecedência para permitir uma boa homogeneização da amostra. Estes teores de umidade foram sempre checados com um dia de antecedência da compactação. $\mathrm{O}$ controle do grau de compactação durante a preparação dos corpos de prova foi feito pela checagem de massas e alturas, tanto de camadas independentes como do corpo de prova como um todo.

Os corpos de prova indeformados foram talhados a partir de blocos de amostra indeformada que foram cuidadosamente coletados, transportados e armazenados. A Figura 4.1(b) ilustra o processo de talhagem, ao final da qual, massas, dimensões e teores de umidade foram checados.

Nos ensaios de deformabilidade e resistência ao cisalhamento, os corpos de prova tiveram relação altura/diâmetro igual a 2. Especificamente para os ensaios com bender elements em condição saturada e em coluna ressonante, os corpos de prova tiveram diâmetro de $7,1 \mathrm{~cm}$ por imposição das dimensões dos equipamentos utilizados. Nos demais ensaios de deformabilidade e resistência, o diâmetro foi de $5,1 \mathrm{~cm}$.

Para as curvas de retenção, os corpos de prova compactados foram preparados seguindose os procedimentos de compactação dinâmica mencionados. Em seguida, foram talhados em anéis de PVC com dimensões internas médias de 1,2 cm de altura e 4,4 cm de diâmetro (Figura $4.1 \mathrm{c})$. Os corpos de prova indeformados foram talhados diretamente da amostra em bloco, em anéis nessas mesmas dimensões.

Para os ensaios de porosimetria, corpos de prova foram compactados do mesmo modo e talhados em dimensões médias de 2,0 cm de altura e 1,5 cm de diâmetro. A Figura 4.1(d) mostra a armazenagem dos corpos de prova após talhagem e secagem ao ar. 

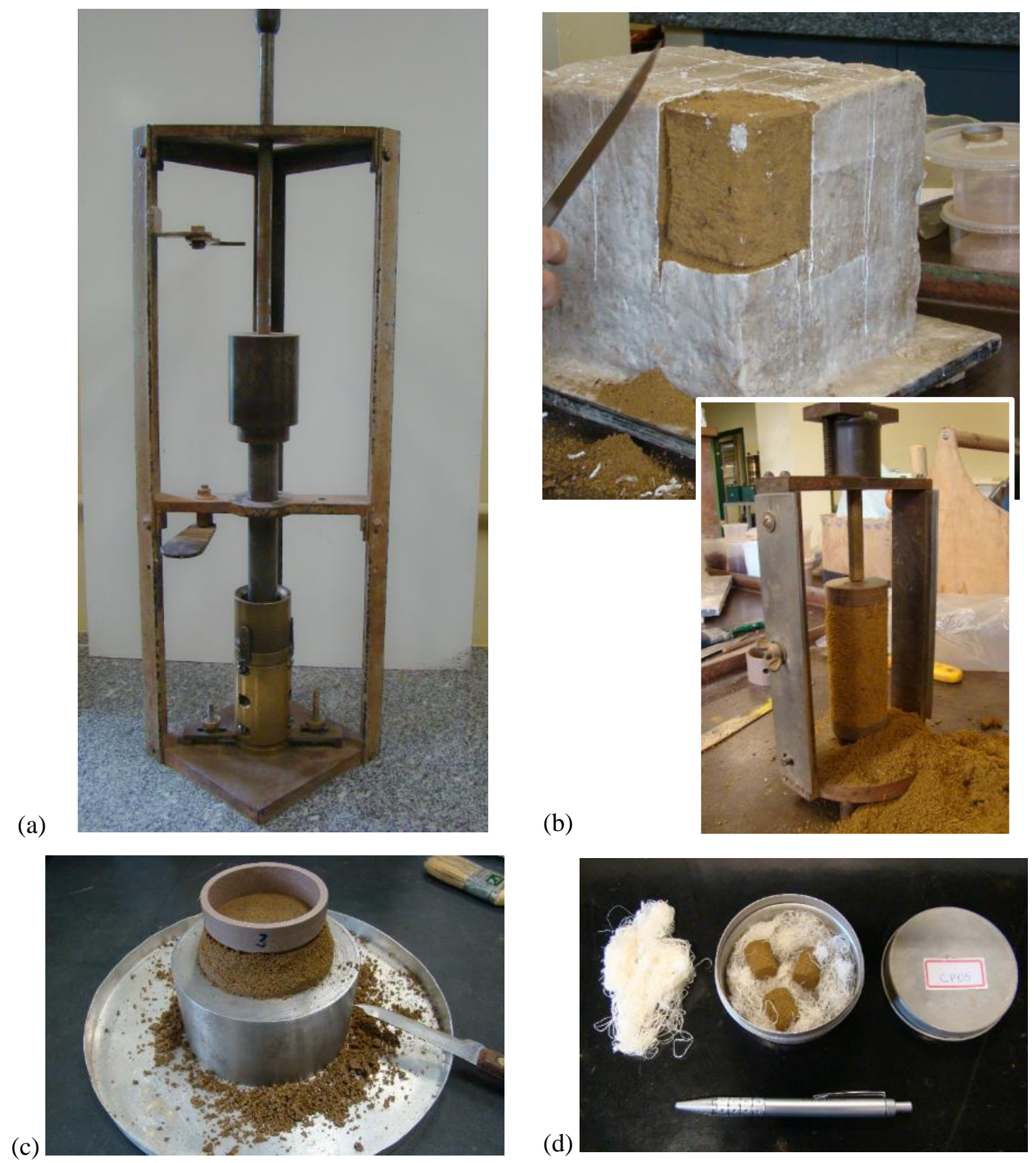

Figura 4.1. Preparação dos corpos de prova (a) compactados, (b) indeformados, (c) para curvas de retenção e (d) porosimetria.

\subsection{ENSAIOS DE PAPEL FILTRO}

O ensaio de papel filtro baseia-se no equilíbrio de potenciais da água no solo e no papel filtro calibrado, como descrito em 2.1.3.1. Nesta pesquisa, a fim de reproduzir as condições dos ensaios de deformabilidade e resistência ao cisalhamento, optou-se por medir a sucção matricial do solo em trajetória de drenagem. O solo foi ensaiado em condição indeformada e compactada 
em dois teores de umidade, a saber teor de umidade ótimo $\left(w_{o t} t\right)$ e $w_{o t}-1 \%$. O procedimento de ensaio seguiu as recomendações de Marinho (1994).

Como preparação para o ensaio, depois de moldados, os corpos de prova foram saturados. A saturação se deu com os corpos de prova sobre pedras porosas grossas revestidas com papel filtro comum e posicionadas em uma bandeja com lâmina de água destilada, como mostra a Figura 4.2 (a). Após um período superior a 24 horas, os corpos de prova foram deixados secar ao ar (Figura 4.2 b) enquanto monitoravam-se suas massas periodicamente. Durante a secagem, buscou-se atingir teores de umidade alvo, que foram definidos a fim de se distribuir os pontos experimentais da curva de retenção de uma maneira razoavelmente uniforme entre teores de umidade correspondentes à saturação e até próximo de zero. Quando o solo apresentou teor de umidade próximo ao valor alvo, ambas as faces do corpo de prova foram postas em contato com papel filtro tipo 2 Whatman \#42 (Figura 4.2 c). Tal contato entre o papel filtro e o solo permitiu à água e aos solutos fluir entre os dois meios, e assim, equilibrar-se sob a sucção matricial do conjunto. Este contato foi facilitado colocando-se discos de PVC sobre os papéis filtro, de acordo com a Figura 4.2 (d). Os corpos de prova foram em seguida embalados e armazenados em recipiente hermético por períodos de oito a quinze dias, a depender da umidade do solo. Passado o tempo de equilíbrio, os papéis filtro foram retirados do contato com o solo e os teores de umidade de ambos o solo e os papéis filtro foram determinados em estufa. Com a média das umidades dos papéis filtro de topo e base, determinou-se a sucção de cada ponto da curva de retenção por meio das correlações de Chandler et al. (1992):

$$
\psi=10^{4,84-0,0622 w_{\text {papel }}}
$$

para $w_{\text {papel }}<47 \%$, e

$$
\psi=10^{6,05-2,48 \log w_{\text {papel }}}
$$

para $w_{\text {papel }} \geq 47 \%$. Nas quais $\psi$ é a sucção do papel filtro em $\mathrm{kPa}$ e $w_{\text {papel }}$ é a umidade gravimétrica do papel filtro em porcentagem. Associando as sucções com os respectivos teores de umidade do solo, construíram-se as curvas de retenção. 
(a)

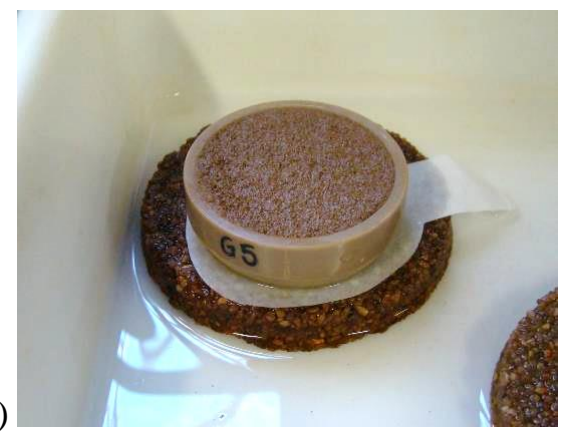

(c)

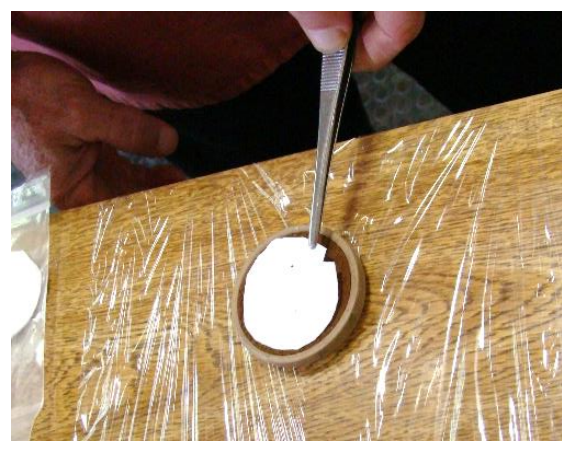

(b)

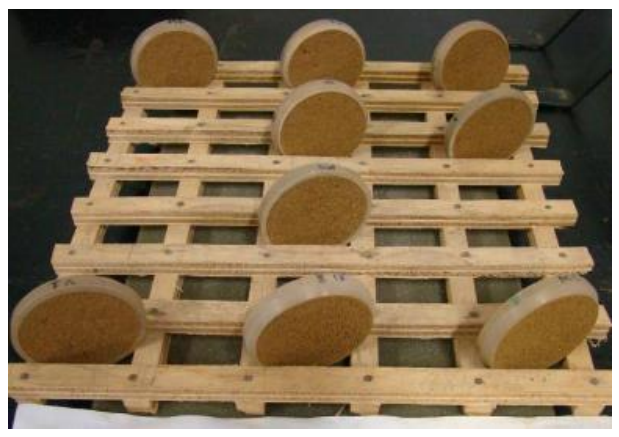

(d)

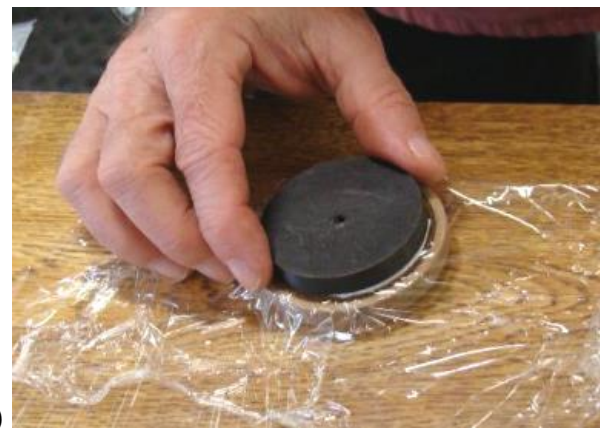

Figura 4.2. (a) Saturação e (b) secagem ao ar dos corpos de prova. (c) Contato com o papel filtro e (d) embalagem dos corpos de prova no ensaio de papel filtro.

\subsection{ENSAIOS DE FUNIL DE PLACA POROSA}

A técnica de funil de placa porosa impõe sucção por meio de uma diferença de cota entre o solo (apoiado sobre uma placa porosa) e um reservatório de água, nos quais atua pressão atmosférica $\left(P_{o}\right)$, como esquematizado na Figura 4.3. O equipamento usado permite aplicação de sucções matriciais entre 1 e $13 \mathrm{kPa}$, e é ilustrado na Figura 4.4. Esta técnica foi utilizada apenas na obtenção de dados experimentais da curva de retenção de água do solo compactado com teor de umidade ótimo.

Em cada ensaio, o corpo de prova saturado como se ilustra na Figura 4.2 (a) foi colocado no interior de uma câmara sobre placa porosa de $100 \mathrm{kPa}$ de entrada de ar, também saturada. $\mathrm{O}$ reservatório de água foi então posicionado na altura que fornece a sucção desejada e permitiuse drenar a água do solo sob tal sucção. Admitiu-se o equilíbrio de potenciais quando se observou cessado o fluxo de água, o que ocorreu no período máximo de 48 horas. Ao final do ensaio foi determinada a umidade do solo correspondente à sucção imposta. 

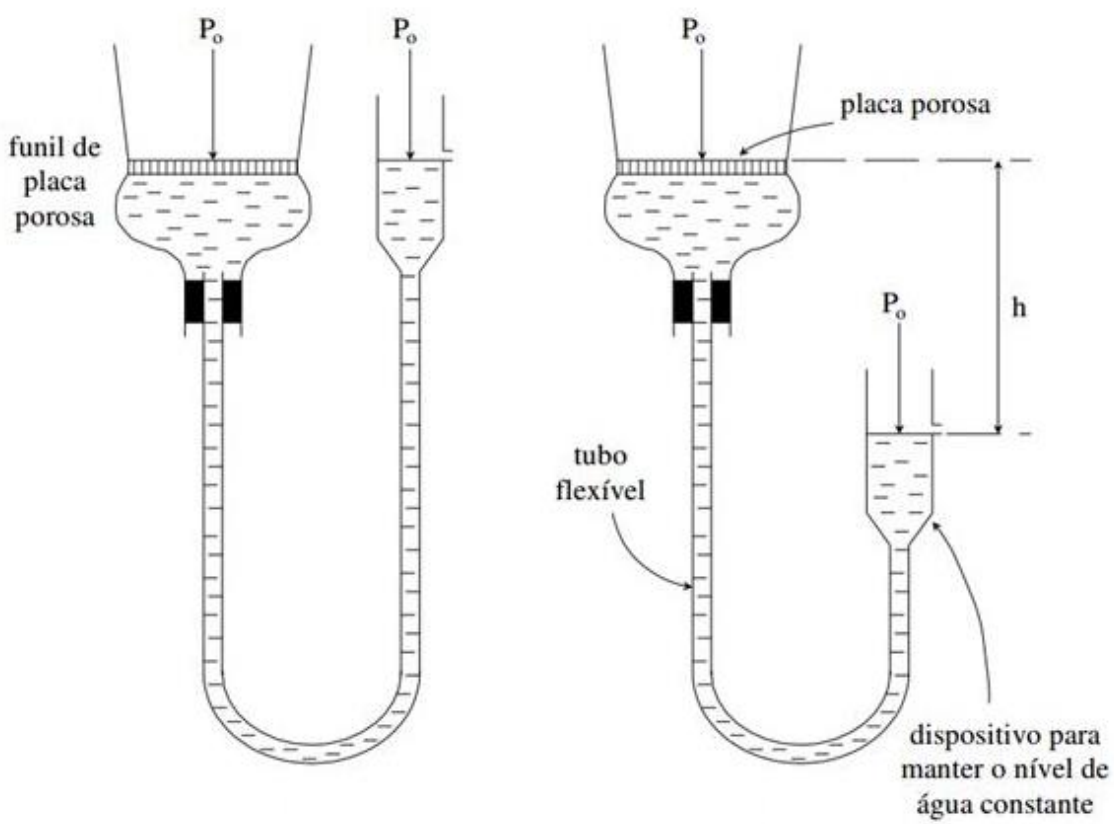

Figura 4.3. Equipamento de funil de placa porosa (Libardi, 1995).

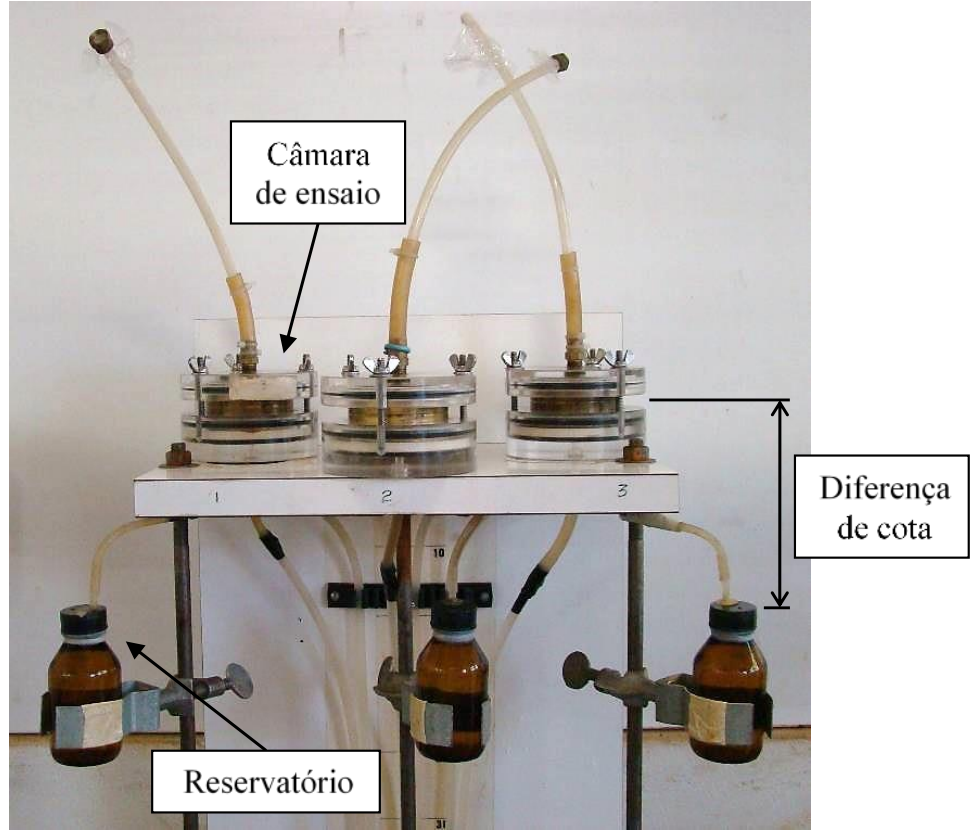

Figura 4.4. Ensaio de funil de placa porosa.

\subsection{ENSAIOS DE POROSIMETRIA POR INTRUSÃO DE MERCÚRIO}

Ensaios de porosimetria por intrusão de mercúrio foram realizados em amostras compactadas nos teores de umidade $w_{o ́ t}$ e $w_{o ́ t}-1 \%$, com a finalidade de determinar o volume e a distribuição volumétrica de poros no solo. Os ensaios foram realizados no Instituto de Física 
de São Carlos da Universidade de São Paulo, segundo a norma ASTM D4404 (2010b). A técnica baseia-se na aplicação de uma pressão externa a um líquido que não molha o solo (mercúrio), forçando o líquido a penetrar em seus poros.

Os corpos de prova foram secos ao ar após a compactação e levados ao penetrômetro do porosímetro, onde o solo entra em contato com o mercúrio, como mostra a Figura 4.5. Em seguida, valores crescentes de pressão são aplicados ao mercúrio, que penetra progressivamente menores poros do solo. Para cada valor de pressão é medido o volume de mercúrio penetrado. Conhecendo-se a tensão superficial do mercúrio e o ângulo de contato entre os materiais, os valores de pressão são convertidos em diâmetro do poro penetrado. Assim, dados de volume dos poros são associados aos respectivos diâmetros.

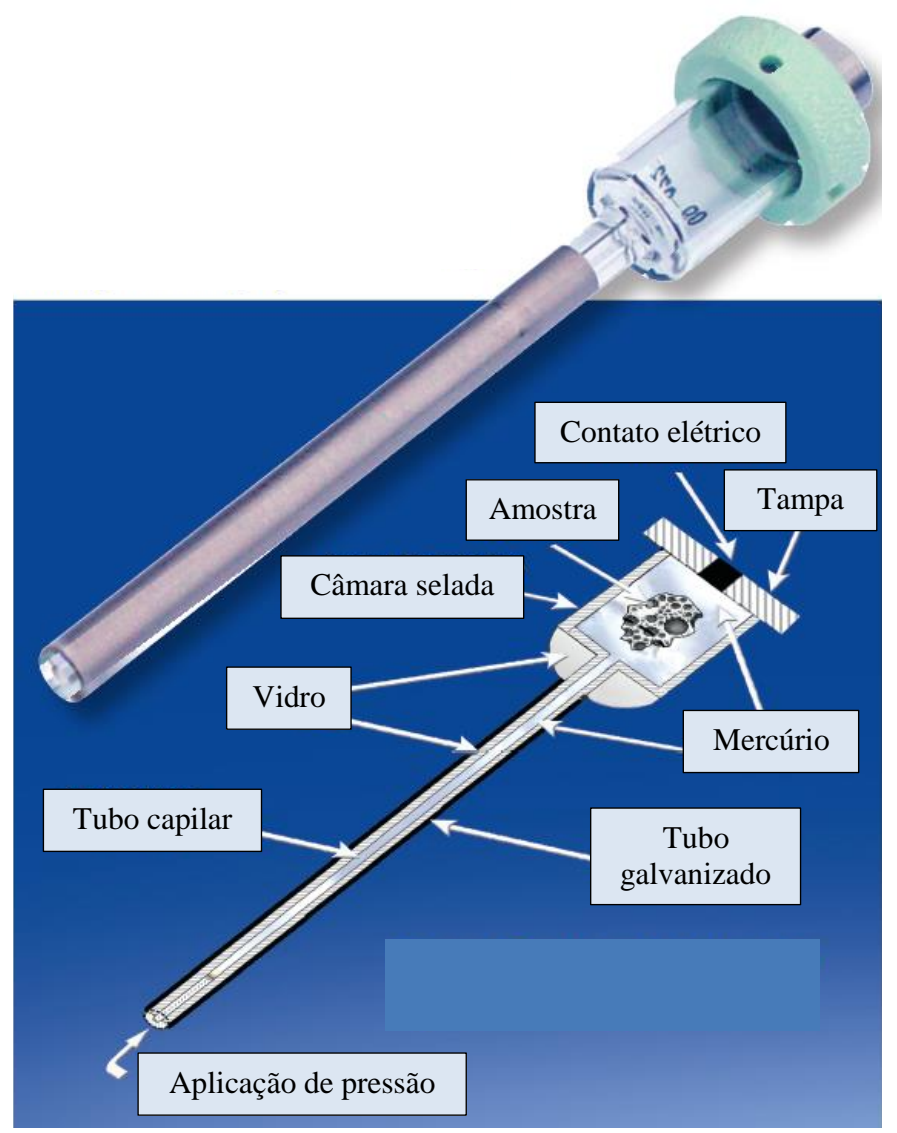

Figura 4.5. Penetrômetro de mercúrio (adaptado de www.micromeritics.com).

\subsection{ENSAIOS DE RESISTÊNCIA AO CISALHAMENTO}

Os ensaios de resistência ao cisalhamento são do tipo compressão triaxial e tiveram início com a montagem e calibração do equipamento esquematizado na Figura 4.6. 


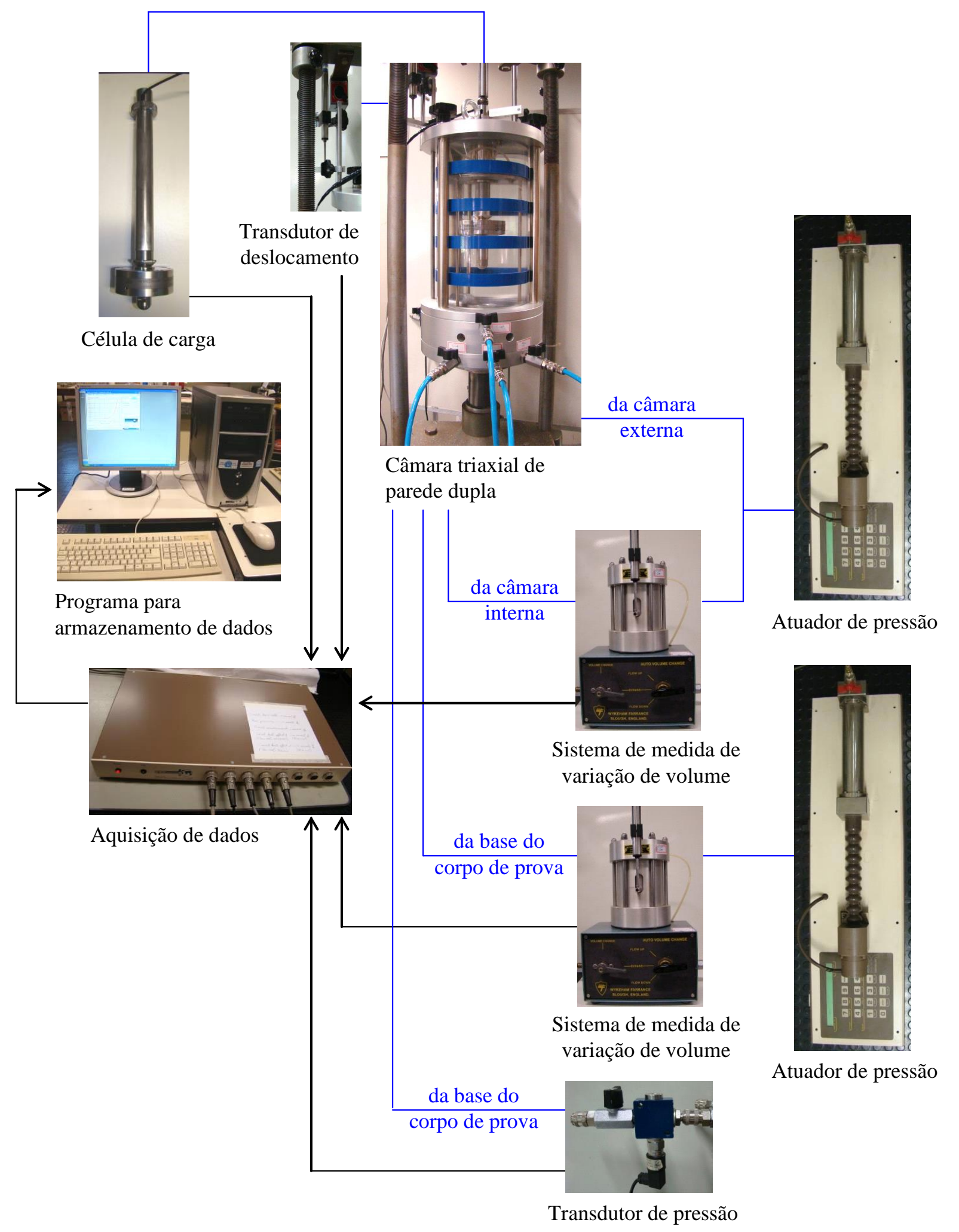

Figura 4.6. Representação esquemática do conjunto de equipamentos para ensaio de compressão triaxial em solo saturado.

Este equipamento conta com uma câmara triaxial de parede dupla, que tem por finalidade tornar mais precisas as medidas de variação de volume total do solo, que rotineiramente são 
tomadas como igual ao volume de água que flui da ou para a câmara de ensaio. Este tipo de medida é afetado tanto por dilatação da câmara de ensaio como por acomodações de outros componentes do equipamento que são pressurizados durante o ensaio. Assume-se que utilizando uma câmara interna dentro de uma câmara externa, ambas submetidas às mesmas pressões, não ocorra variação de volume da câmara interna devido a tais pressões. No equipamento utilizado, a igualdade de pressões nas câmaras interna e externa é garantida pelo uso de uma mesma fonte de pressão para ambas.

O equipamento para compressão triaxial contou ainda com uma prensa de capacidade de 5 toneladas; duas fontes de pressão de água, uma para as câmaras e outra para a contrapressão, cada uma conectada em série a um sistema de medida de variação de volume; um transdutor de pressão que se comunica com a base do corpo de prova; uma célula de carga submersível com capacidade de medida de $5 \mathrm{kN}$; um transdutor de deslocamento externo à câmara de ensaio; interface e software para aquisição e armazenamento de dados dos ensaios. No caso específico dos ensaios com solo não saturado, uma fonte de pressão de ar e um pedestal com pedra porosa de 100 ou $300 \mathrm{kPa}$ de entrada de ar foram adicionados ao conjunto.

Após a calibração deste equipamento, foram iniciados os ensaios de compressão triaxial em solo compactado no teor de umidade ótimo e indeformado. Os ensaios com solo saturado foram do tipo adensado-drenado (CD) e adensado-não drenado (CU) e com solo não saturado foram do tipo com teor de umidade constante $(\mathrm{CW})$.

\subsubsection{Ensaios adensado-drenado e adensado-não drenado}

O procedimento adotado para os ensaios CD e CU foi de saturação dos corpos de prova utilizando contrapressão, sendo que valores do parâmetro $B$ superiores a 0,95 foram considerados suficientes. Em seguida o solo foi adensado isotropicamente, sendo que as variações volumétricas dos corpos de prova foram medidas tanto na drenagem de água da base do corpo de prova quanto na drenagem da câmara interna. Depois de adensados, os corpos de prova foram levados à ruptura com velocidade constante de deslocamento de $0,060 \mathrm{~mm} / \mathrm{min}$ para os ensaios CD e 0,076 mm/min para os ensaios $\mathrm{CU}$, que correspondem a taxas de deformações de $0,060 \% / \mathrm{min}$ e $0,076 \% / \mathrm{min}$, respectivamente, e são inferiores aos valores calculados a partir das recomendações de Head (1986).

Em dois ensaios do tipo CD utilizou-se a técnica de múltiplos estágios, visando melhor aproveitamento dos corpos de prova talhados de amostra indeformada. Nestes casos, após a 
definição da curva tensão $v s$ deformação do primeiro cisalhamento, os corpos de prova foram descarregados mantendo-se a mesma velocidade de deslocamento. Nos estágios seguintes o solo foi adensado sob maior tensão confinante líquida $\left(\sigma_{3}-u_{w}\right)$ e novamente cisalhado.

\subsubsection{Ensaios com teor de umidade constante}

Nos ensaios com teor de umidade constante, os corpos de prova foram submetidos a uma etapa de pré-condicionamento com imposição de sucção, que teve a finalidade de reduzir o tempo de permanência de cada corpo de prova na câmara de ensaio. Esta etapa iniciou-se com o umedecimento dos corpos de prova por ascensão capilar e gotejamento de água no topo, como se vê na Figura 4.7 (a), para que todos os corpos de prova seguissem trajetória de drenagem. Em seguida, estes foram levados a câmaras auxiliares com pedras porosas de alta pressão de entrada de ar em suas bases (Figura 4.7 b), onde a sucção de ensaio foi imposta usando a técnica de translação de eixos. Em todos os ensaios em que foram utilizadas pedras porosas de alta pressão de entrada de ar, as mesmas foram limpas e saturadas antes de cada ensaio. Para a imposição da sucção nos corpos de prova, adotou-se uma mesma pressão na água intersticial de $50 \mathrm{kPa}$ e a pressão no ar variou de acordo com a sucção alvo. A permanência dos corpos de prova nestas câmaras variou de acordo com a sucção imposta e a pressão de entrada de ar das pedras porosas, que comandam a condutividade hidráulica do sistema pedra porosa-solo.

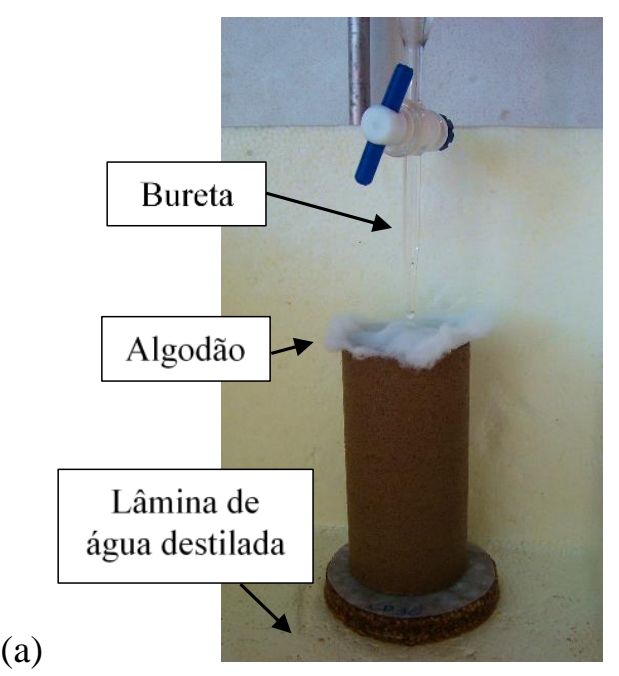

(b)

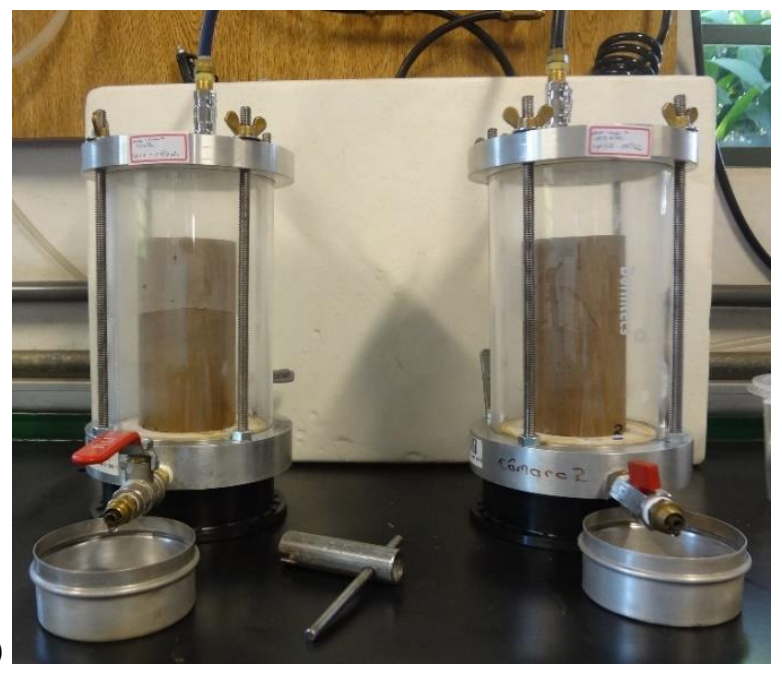

Figura 4.7. Pré-condicionamento dos corpos de prova para ensaios não saturados.

Já na câmara de compressão triaxial, as etapas de ensaio foram de equilíbrio da sucção após a montagem do ensaio, adensamento, estabilização da sucção após adensamento e 
cisalhamento. Na etapa de equilíbrio da sucção, buscou-se restabelecer as pressões no solo que haviam sido perturbadas durante a montagem. Para isso reaplicaram-se as mesmas pressões aos fluidos intersticiais e adicionalmente, uma tensão de confinamento, de modo que a tensão confinante líquida $\left(\sigma_{3}-u_{a}\right)$ fosse de $10 \mathrm{kPa}$. No adensamento a tensão confinante líquida foi elevada e as fases ar e água do solo permaneceram drenadas com pressões mantidas constantes. O volume de água drenado do corpo de prova foi medido e sua estabilização foi tomada como critério de encerramento desta fase. Findo o adensamento, a drenagem de água da base do corpo de prova foi fechada e permitiu-se que a pressão da água intersticial variasse até o equilíbrio, na fase denominada estabilização da sucção após o adensamento. Nesta condição iniciou-se o cisalhamento do corpo de prova mantendo ainda impedido o fluxo da água intersticial. $\mathrm{O}$ cisalhamento se deu à velocidade constante de deslocamento de $0,004 \mathrm{~mm} / \mathrm{min}$, correspondendo a uma taxa de deformação inicial de $0,004 \% / \mathrm{min}$, que é inferior às utilizadas em Röhm (1992) e Georgetti (2010) para o mesmo solo. Esta taxa de deformação também é menor do que a utilizada por Patil et al. (2014) em uma areia siltosa compactada.

Com a finalidade de reduzir o tempo de obtenção dos resultados e também a variabilidade inerente à preparação de corpos de prova, optou-se pela execução de múltiplos estágios de adensamento e ruptura nos ensaios $\mathrm{CW}$. Em cada estágio, a tensão confinante líquida foi elevada e a sucção na fase de adensamento foi mantida. A fase de cisalhamento foi levada até deformações axiais próximas a 5\% para os primeiros estágios, que corresponde à deformação axial na qual a tensão resistida, a sucção e a deformação volumétrica do solo mostraram tendência de estabilização em ensaios preliminares com solo compactado. No último estágio de cada ensaio, deformações axiais maiores foram permitidas.

\subsection{ENSAIOS DE DEFORMABILIDADE}

Os ensaios para medida da deformabilidade do solo compreenderam ensaios com bender elements, de compressão triaxial com instrumentação interna e em coluna ressonante com sucção ou teor de umidade constantes, como mostrado na Figura 3.1. Especificamente, os ensaios de coluna ressonante foram realizados no Laboratório de Engenharia Civil da Universidade do Texas em Arlington, sob a supervisão do Professor Dr. Laureano Hoyos. A seguir, faz-se uma descrição de cada uma destas técnicas empregadas para se avaliar a deformabilidade do solo em estudo. 


\subsubsection{Ensaios com bender elements}

Os ensaios com bender elements tiveram como finalidade a determinação do módulo de cisalhamento máximo do solo saturado e não saturado.

\subsubsection{Solo saturado}

Os ensaios com solo saturado utilizaram um par de bender elements inseridos em pedestal e cabeçote de uma câmara triaxial, juntamente com um sistema de aquisição de dados e um software com osciloscópio, responsável pela geração de sinais e armazenamento de dados. O equipamento é esquematizado na Figura 4.8 (a). Este equipamento, cedido pelo Prof. Dr. Heraldo Giacheti da Universidade Paulista Júlio de Mesquita Filho (UNESP/Campus Bauru), foi instalado em uma câmara triaxial convencional adaptada para este uso (Figuras 4.8 b e c). A câmara triaxial foi alimentada por duas fontes de pressão de água (uma para confinamento e outra para contrapressão) e instrumentada com transdutor de pressão e sistema de medida de variação de volume, todos previamente calibrados.

Corpos de prova compactados com diferentes teores de umidade tiveram ranhuras cuidadosamente feitas em posições simétricas no topo e na base, por moldes cujas dimensões são próximas às dos bender elements. Após a execução das ranhuras, estas foram preenchidas com graxa de silicone a fim de se garantir o contato entre o solo e os bender elements na execução dos ensaios. Os acessórios utilizados são mostrados na Figura 4.9. Depois disso, os corpos de prova foram levados à câmara de ensaio e saturados por contrapressão mantendo-se uma tensão confinante líquida de $10 \mathrm{kPa}$. $\mathrm{O}$ parâmetro $B$ foi tomado como indicativo de saturação para valores iguais ou maiores que 0,95 . Em seguida realizaram-se etapas sucessivas de adensamento isotrópico. A trajetória de tensão escolhida foi de confinamento em etapas até $500 \mathrm{kPa}$, seguido de desconfinamento até $25 \mathrm{kPa}$ e reconfinamento até $250 \mathrm{kPa}$. As etapas de adensamento foram consideradas completas quando notaram-se estabilizadas as medidas de variação de volume pelo fluxo de água da câmara triaxial. Ao final de cada uma destas etapas, pulsos de cisalhamento senoidais foram transmitidos ao solo, com amplitude de 14 volts e frequências que variaram de $1 \mathrm{a} 16,7 \mathrm{kHz}$. 

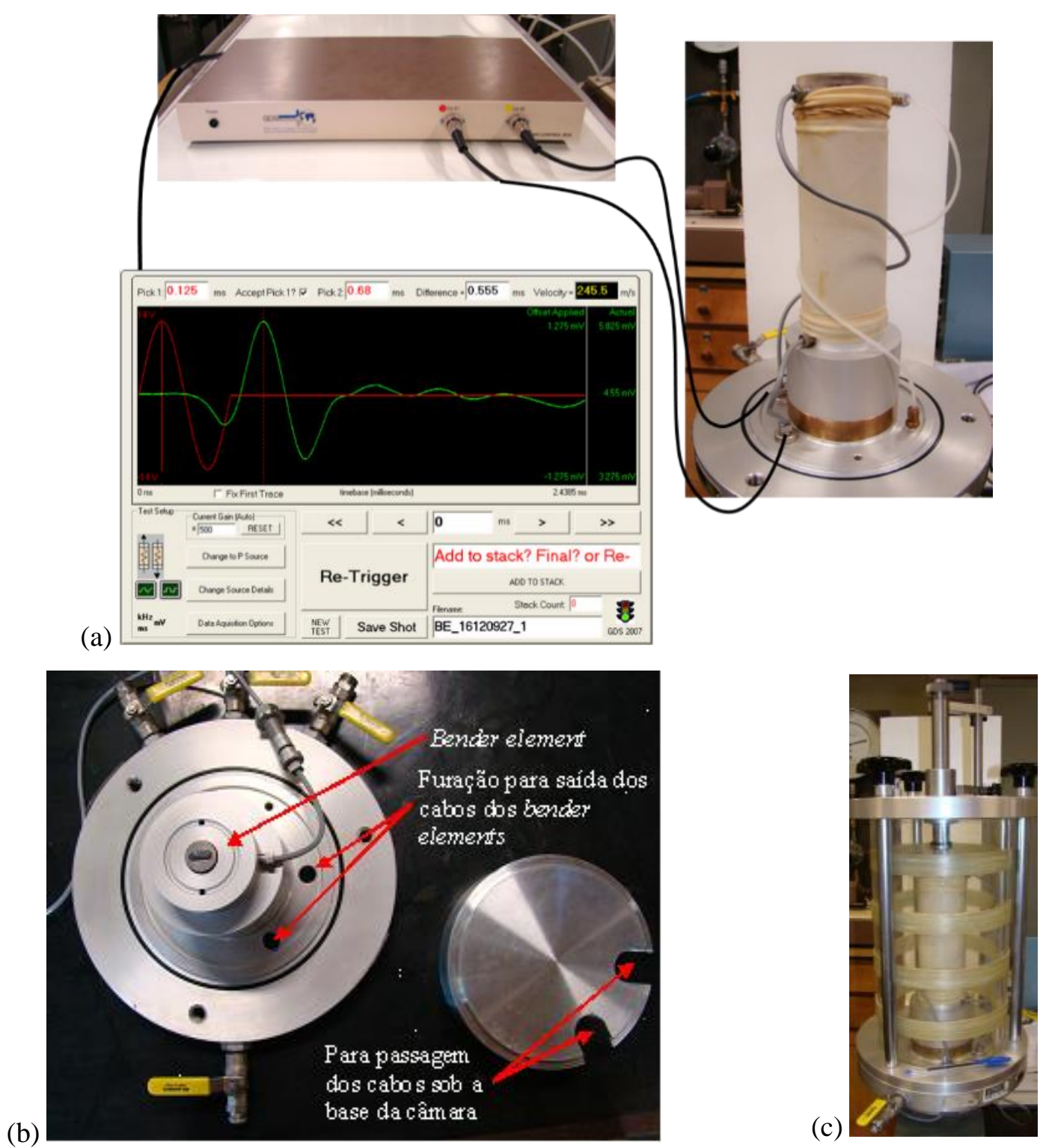

Figura 4.8. (a) Representação esquemática dos equipamentos para ensaio com bender elements, e (b) e (c) adaptação de câmara triaxial e pedestal com bender element.

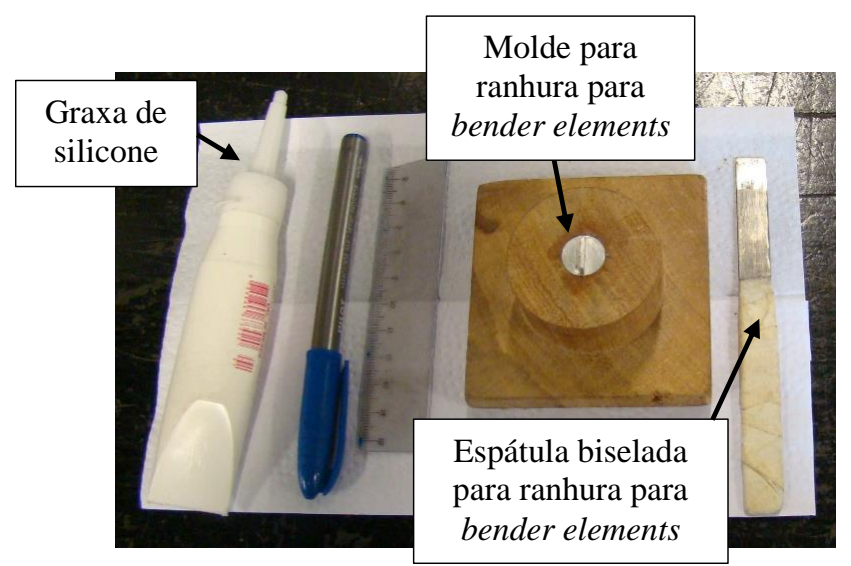

Figura 4.9. Acessórios para a execução de ranhura para alocação de bender elements no solo. 
Para análise de resultados destes ensaios, são dados fundamentais a massa específica do solo, a distância percorrida pelo pulso de cisalhamento e o tempo deste percurso. A massa específica do solo foi calculada a partir dos dados de moldagem e variações de volume do corpo de prova registradas ao longo do ensaio, e considerando grau de saturação 100\%. A distância percorrida pelo pulso de cisalhamento $\left(L_{t t}\right)$ foi tomada como a distância entre as extremidades dos bender elements, seguindo sugestões de Viggiani e Atkinson (1995) e Dyvik e Madshus (1985), entre outros. Para isso, o comprimento saliente dos elementos, que penetra no solo, foi descontado da altura do corpo de prova. Esta altura, por sua vez, foi corrigida ao final de cada etapa de confinamento a partir da variação de volume do solo. Quanto ao tempo de percurso $(t)$, este foi tomado como a primeira maior deflexão do sinal recebido, como ilustra a Figura 4.10. Trata-se este de um método direto, bastante utilizado (Fioravante e Capoferri, 2001; Lee e Santamarina, 2005; Takkabutr, 2006; Chan, 2010) e que contribui para a simplicidade da interpretação dos ensaios com bender elements.

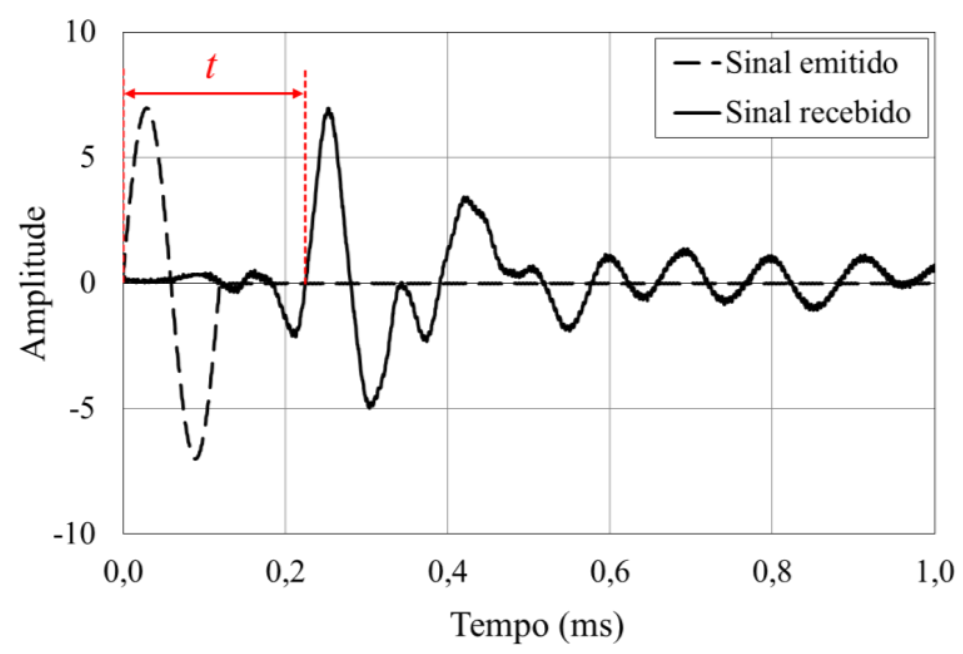

Figura 4.10. Determinação do tempo de percurso da onda.

\subsubsection{Solo não saturado}

Os ensaios com bender elements em solo não saturado contaram com um pedestal com pedra porosa de $500 \mathrm{kPa}$ de entrada de ar incrustada (Figura 4.11 a). Neste caso o conjunto de pedestal e cabeçote foi introduzido em uma câmara triaxial Bishop-Wesley. Esta câmara permite a utilização de instrumentação interna para medida das variações de volume diretamente no corpo de prova, para as quais se utilizaram transdutores de efeito Hall (Figura 
4.11 b). Anteriormente aos ensaios, os transdutores foram calibrados, e também checados novamente ao final de cada um deles. Com relação ao equipamento usado para ensaios com solo saturado, este equipamento contou ainda com uma fonte de pressão de ar, necessária para controle da sucção do solo durante o ensaio.

(a)

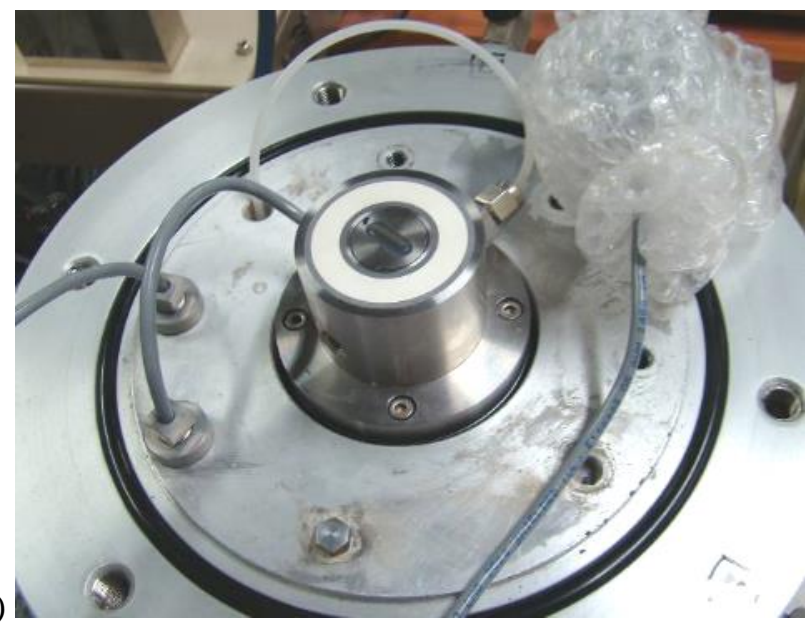

(b)

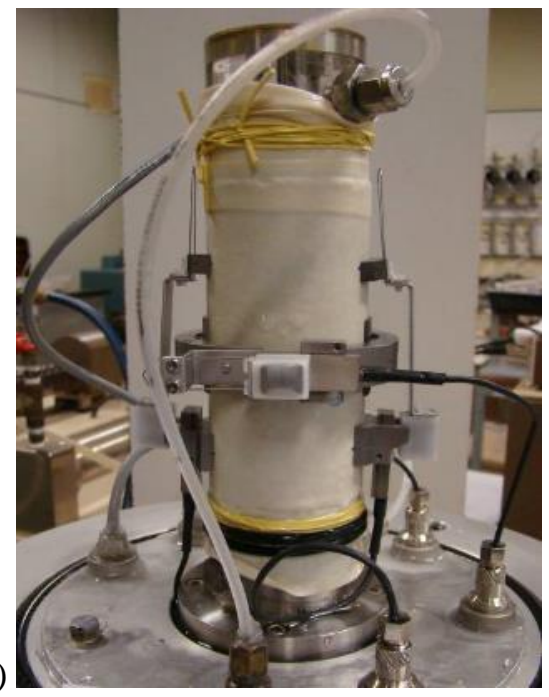

Figura 4.11. (a) Pedestal com pedra porosa de alta pressão de entrada de ar e bender element e (b) corpo de prova instrumentado para ensaio com bender elements em condição não saturada.

Para os ensaios com solo não saturado, ranhuras para acomodação dos bender elements foram feitas nos corpos de prova após moldagem e em seguida, estes foram pré-condicionados como descrito no item 4.6.2 e ilustrado na Figura 4.7. Depois de instalada a sucção, procedeuse a montagem do ensaio e uma etapa de equilíbrio da sucção, que ocorreu com descrito em 4.6.2. Após isso, sucessivas etapas de confinamento isotrópico e transmissão de pulsos de cisalhamento foram realizadas. Cada etapa de confinamento foi encerrada quando se notou tendência de equilíbrio nas variações de volume de água do solo e das dimensões medidas pelos transdutores locais de deslocamento. Para a etapa seguinte, a tensão confinante foi alterada enquanto as pressões no ar e na água do solo foram mantidas constantes, ou seja, em condição drenada. Nas emissões de ondas de cisalhamento, estes ensaios utilizaram a mesma amplitude e um intervalo maior de frequências em relação aos ensaios com solo saturado, que foi de 1 a $50 \mathrm{kHz}$. Para determinação de massa específica do solo, distância percorrida pelo pulso de cisalhamento e o tempo de percurso, utilizou-se a mesma metodologia descrita para o solo saturado, sendo que no caso do solo não saturado, as medidas de variações de volume total do solo foram fornecidas pelos transdutores de efeito Hall e as medidas de variações de volume de água foram fornecidas por um atuador de pressão responsável pela pressão na água intersticial. 


\subsubsection{Ensaios de compressão triaxial com instrumentação interna}

Ensaios de compressão triaxial com instrumentação interna foram realizados em solo compactado no teor de umidade ótimo e saturado. Estes ensaios tiveram o objetivo de avaliar a degradação do módulo de cisalhamento em deformações de até 1\%. A instrumentação contou com transdutores de efeito Hall medindo deslocamentos diretamente nos corpos de prova, como mostrado na Figura 4.11 (b). O propósito da utilização destes transdutores é de obter medidas mais precisas de deformações em uma faixa onde medidas convencionais de deslocamento externas à câmara de ensaio não apresentam precisão, como relatado por Jardine et al. (1984).

Os ensaios de compressão triaxial para determinar a degradação do módulo de cisalhamento foram do tipo adensado e drenado com controle de deformações. A saturação dos corpos de prova se deu por contrapressão até se obter $B$ maior ou igual a 0,95 . A seguir, na fase de adensamento isotrópico, tensões confinantes líquidas de 50, 100 e $300 \mathrm{kPa}$ foram utilizadas. Quando as medidas de variação volumétrica se estabilizaram, o solo foi levado à ruptura em compressão axial em condição drenada com taxa de deformação de 0,060\%/min. Módulos e deformações cisalhantes foram calculados a partir das curvas tensão vs deformação e deformações volumétricas.

\subsubsection{Ensaios com sucção constante em coluna ressonante}

Corpos de prova não saturados foram ensaiados em um equipamento de coluna ressonante com extremidades fixa e livre (Figura 4.12). Estes ensaios tiveram a finalidade de avaliar a evolução da deformabilidade do solo compactado não saturado em condição drenada.

Antes dos ensaios, os corpos de prova tiveram a sucção proveniente da compactação reduzida por ascensão capilar, em um procedimento semelhante ao mostrado na Figura 4.7 (a). Em seguida os corpos de prova foram transportados para uma balança onde se permitiu a secagem ao ar até teores de umidade pré-definidos. Estes teores de umidade foram definidos com base na curva de retenção de água do solo para que ao final desta etapa o corpo de prova estivesse em torno de $0,5 \%$ mais úmido do que os teores de umidade correspondentes às sucções de 15, 40 e $100 \mathrm{kPa}$. Então, os corpos de prova foram embalados em filme PVC e saco plástico e mantidos em uma câmara com temperatura controlada por um período de 7 dias, para homogeneização interna da umidade. 


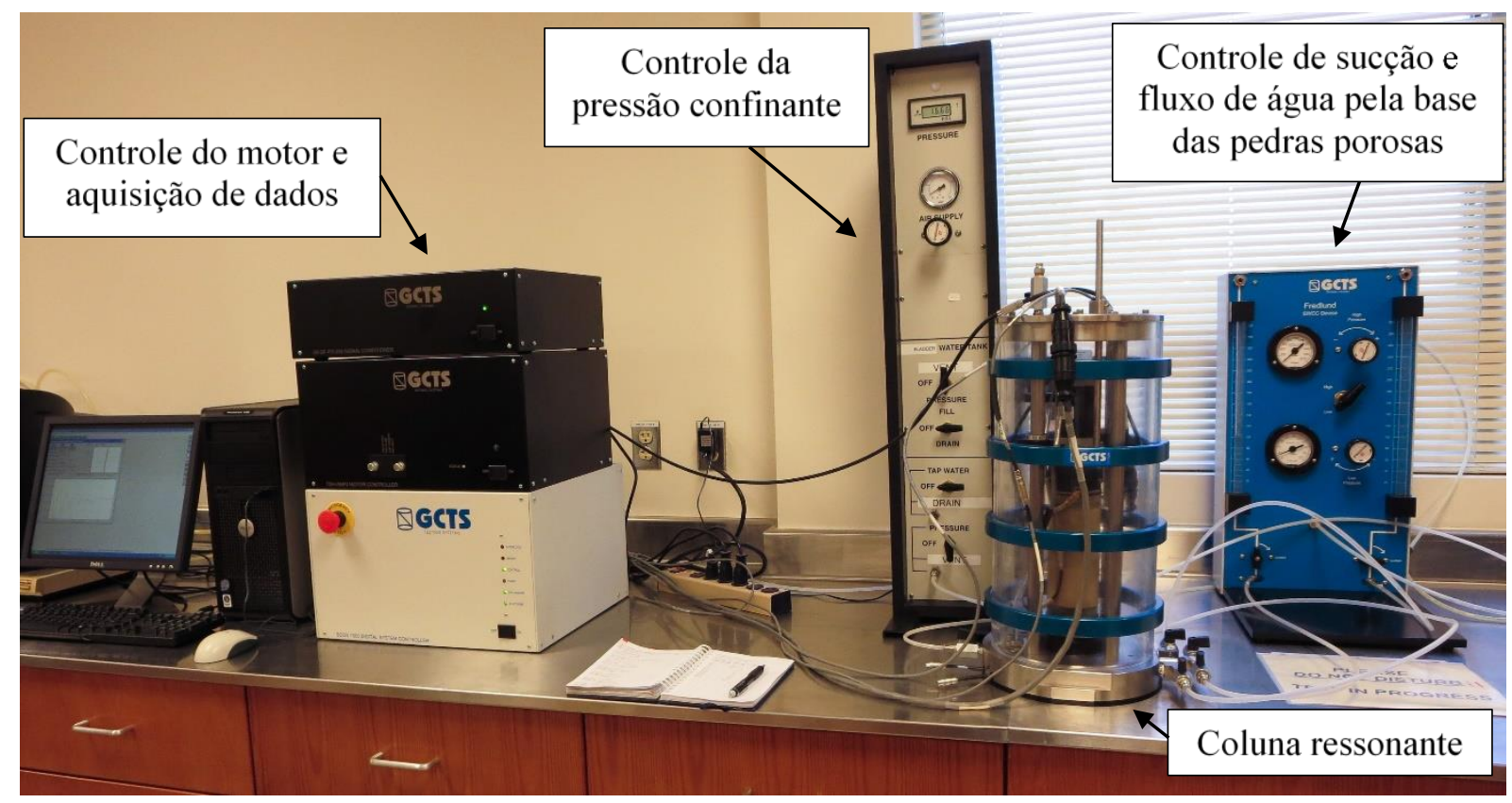

Figura 4.12. Equipamento para ensaio em coluna ressonante com controle de sucção.

Após este período, deu-se a montagem do ensaio (Figura 4.13 a) e o confinamento isotrópico do solo sob uma tensão confinante líquida de $50 \mathrm{kPa}$ e a sucção pré-condicionada. A tensão de confinamento foi aplicada usando pressão de ar, diferentemente de todos os demais ensaios. Isso porque o motor de aplicação de torque e outros sensores e cabos encontram-se dentro da câmara de ensaio, e estes equipamentos são danificados na presença de água. A técnica de translação de eixos foi usada para controlar a sucção no solo, sendo a pressão na água intersticial igual a zero. Sob este novo estado de tensão, permitiu-se a consolidação do solo enquanto monitoravam-se o deslocamento vertical e o volume de água drenado do corpo de prova. Durante este período, fluxos de água destilada e deaerada removeram eventuais bolhas de ar acumuladas na base das pedras porosas de alta pressão de entrada de ar presentes na câmara. Este processo foi repetido a cada 2 dias. Ao se observar equilíbrio em ambos o deslocamento vertical e a água drenada do solo, iniciou-se o ensaio.

O ensaio de coluna ressonante consistiu basicamente em aplicações de torque no topo do corpo de prova por meio de oscilações harmônicas, enquanto se realizava uma varredura de frequências. O equipamento tem capacidade de aplicar torques até $1000 \mathrm{Nm}$ e frequências até $300 \mathrm{~Hz}$. Os deslocamentos angulares no topo do corpo de prova, causados por tais solicitações torcionais, foram registrados por um transdutor de proximidade, ilustrado na Figura 4.13 (b). As solicitações foram realizadas em estágios, com torques variando de 50 a $1000 \mathrm{Nm}$, dos quais se obtiveram respostas de frequência do corpo de prova. Estes dados foram posteriormente analisados para cálculo do módulo de cisalhamento e da razão de amortecimento do solo. Ao 
final de cada estágio, quando a oscilação torcional forçada foi interrompida, permitiu-se ao corpo de prova vibrar livremente até o repouso. Estes dados de vibração livre também foram registrados para análise das características de amortecimento do solo.

(a)

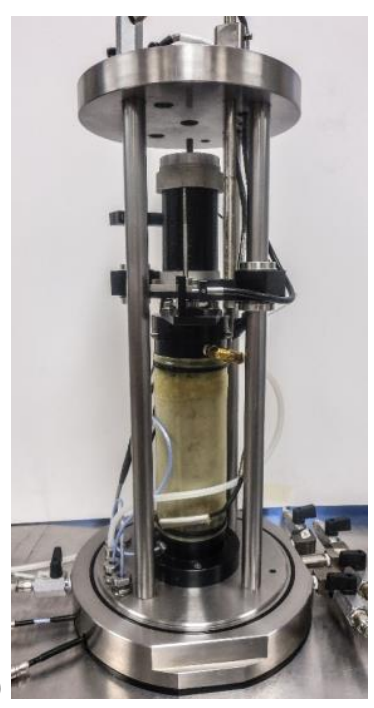

(b)
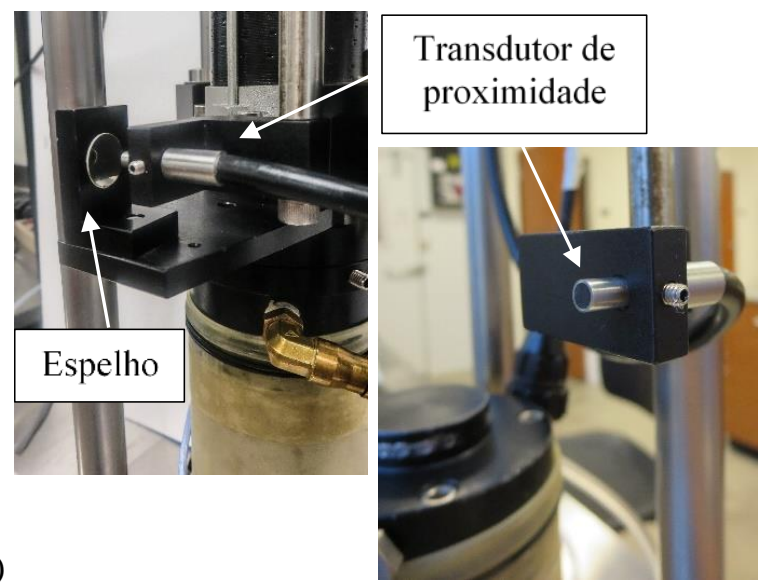

Figura 4.13. (a) Montagem do ensaio de coluna ressonante com sucção constante e (b) transdutor de proximidade.

\subsubsection{Ensaios com teor de umidade constante em coluna ressonante}

Corpos de prova de solo não saturado foram ensaiados a teor de umidade constante em um segundo equipamento de coluna ressonante com extremidades fixa e livre, mostrado na Figura 4.14. Estes ensaios permitiram uma análise da evolução da deformabilidade do solo compactado não saturado em condição não drenada.

Neste equipamento, o sistema oscilador utiliza eletroímãs e bobinas, indicados na Figura 4.15, que são excitados por correntes elétricas senoidais de amplitudes de até $5 \mathrm{~V}$. Com isso, cria-se um campo magnético que provoca solicitações torcionais no corpo de prova. As ondas elétricas são emitidas com frequências crescentes, promovendo uma varredura de frequências. As amplitudes de onda, por sua vez, são responsáveis por diferentes intensidades de torques. A resposta do solo às vibrações torcionais são captadas por um acelerômetro conectado a um amplificador de sinal. Do amplificador, os sinais vindos do acelerômetro são transmitidos a um analisador de sinal digital com osciloscópio, que permite sua gravação.

Para os ensaios, corpos de prova foram compactados em distintos teores de umidade e suas correspondentes sucções foram inferidas a partir da curva de retenção de água. Estes valores de sucção são referidos como sucção inicial do solo. 


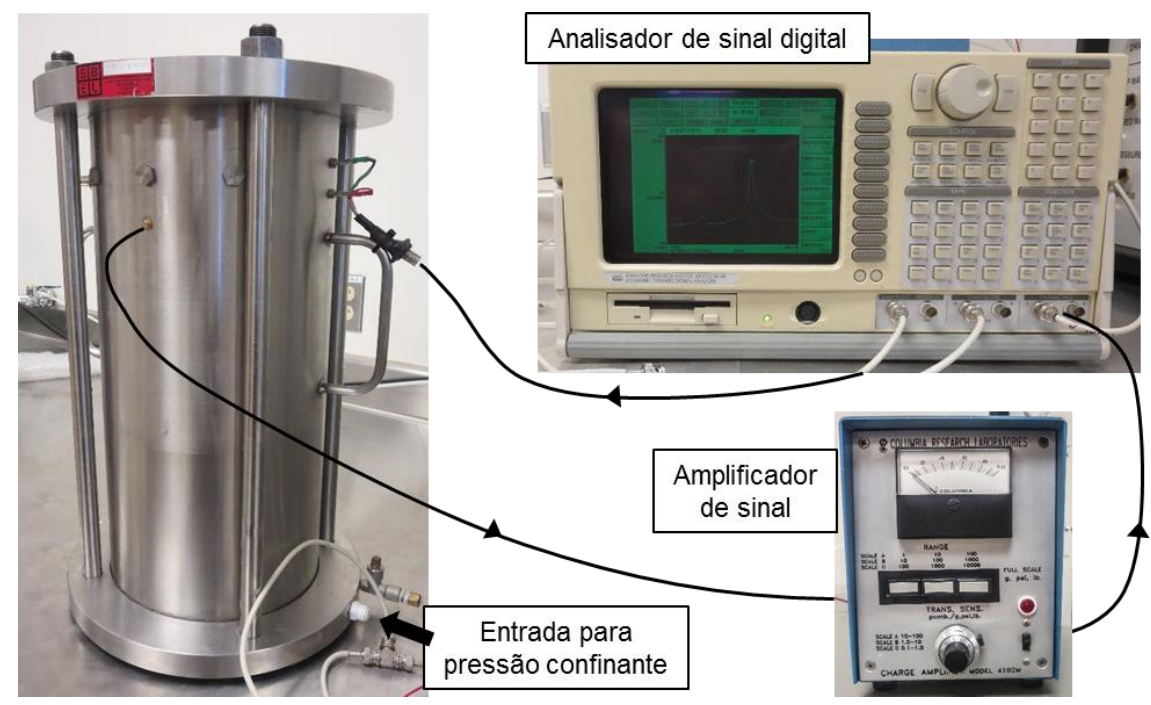

Figura 4.14. Equipamento para ensaio em coluna ressonante com teor de umidade constante.

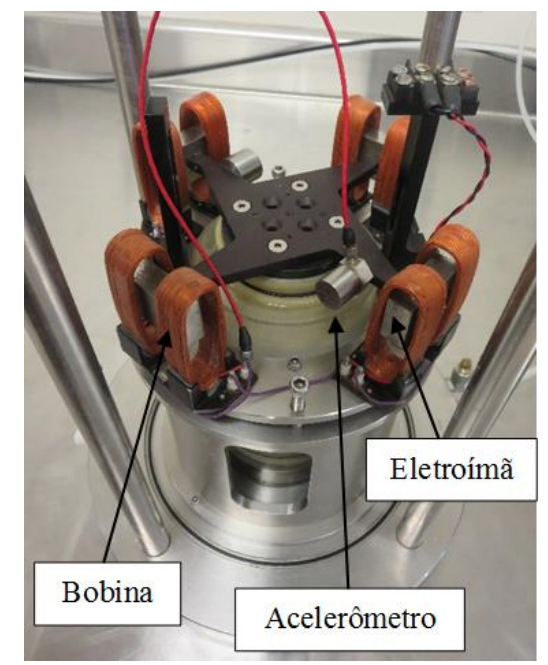

Figura 4.15. Sistema oscilador na coluna ressonante para ensaios com teor de umidade constante.

Dois conjuntos de ensaios foram realizados usando este equipamento. Um primeiro focando na obtenção de características de deformabilidade a muito pequenas deformações, isto é, módulos de cisalhamento máximos e razões de amortecimento mínimos, para diferentes teores de umidade em diferentes níveis de confinamento. Neste conjunto, tensões confinantes entre 10 e $500 \mathrm{kPa}$ foram aplicadas ao solo em estágios. Os fluidos intersticiais foram mantidos não drenados e seus valores não foram medidos. Variações de volume também não foram monitoradas. Em cada estágio de confinamento, a resposta do solo às solicitações no nível de pequenas deformações foi checada por uma varredura de frequências enquanto se supria o sistema oscilador com uma corrente de $0,25 \mathrm{~V}$. Cada estágio de confinamento durou 24 horas, quando não mais se notaram alterações na frequência de ressonância. A tensão confinante foi então aumentada para o próximo estágio. Ao se atingir $500 \mathrm{kPa}$, a voltagem de entrada foi 
aumentada em estágios até $5 \mathrm{~V}$ a fim de captar a degradação da frequência de ressonância com o aumento das deformações. Já no segundo conjunto, foram obtidas as variações na deformabilidade do solo compactado no teor de umidade ótimo para diferentes níveis de confinamento. Cada corpo de prova foi submetido a uma única tensão confinante e ensaiado com voltagens variando entre 0,25 e $5 \mathrm{~V}$. 


\section{RESULTADOS E ANÁLISES}

\subsection{CARACTERIZAÇÃO DO SOLO}

A Figura 5.1 (a) mostra a curva granulométrica do solo em estudo, que foi classificado como uma areia média a fina argilosa marrom. O Sistema Unificado de Classificação dos Solos categoriza este solo como SC. Outras características determinadas são massa específica dos sólidos de 2,65 g/ $\mathrm{cm}^{3}$, limite de liquidez de 32\%, limite de plasticidade de 16\%. Do ensaio de compactação na energia Proctor Normal, a curva de compactação obtida é apresentada na Figura 5.1 (b), sendo a massa específica seca máxima e teor de umidade ótimo iguais a 1,80 $\mathrm{g} / \mathrm{cm}^{3}$ e $13,8 \%$, respectivamente. As curvas correspondentes aos graus de saturação $\left(S_{r}\right)$ de 80 , 90 e 100\% também são mostradas nessa figura. Pela classificação MCT (Miniatura Compactado Tropical), o solo foi designado como laterítico arenoso (LA').

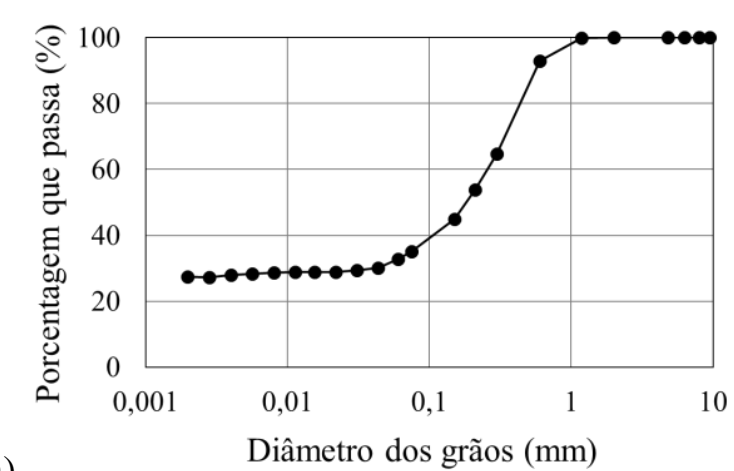

(a)

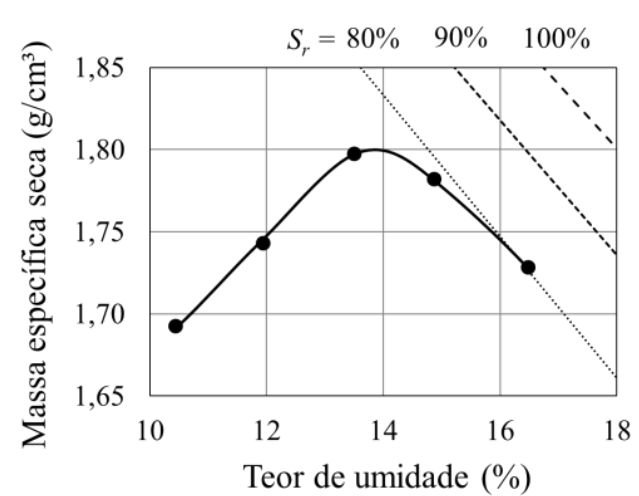

(b)

Figura 5.1. (a) Curva granulométrica e (b) de compactação do solo.

As curvas de retenção de água do solo foram determinadas em trajetória de drenagem tanto para o solo compactado quanto indeformado. Os índices físicos médios de moldagem dos corpos de prova para cada tipo de amostra encontram-se na Tabela 5.1. As curvas de retenção são apresentadas na Figura 5.2, onde se observa em (a) os dados experimentais de teores de umidade gravimétricos $v s$ sucções matriciais para o solo compactado com grau de compactação de $95 \%$ nos teores de umidade ótimo $\left(w_{o ́ t}=13,8 \%\right)$ e $w_{o t}-1 \%$. Estes ensaios tiveram a finalidade de comparar o comportamento das curvas de retenção de diferentes condições de compactação utilizadas nesta pesquisa. Nota-se nessa figura que os pontos experimentais encontram-se praticamente sobrepostos em toda a faixa de sucções analisadas, refletindo a influência do 
índice de vazios na retenção de água, uma vez que buscou-se atingir a mesma massa específica seca durante a preparação de todos os corpos de prova. Com isso, pode-se afirmar que a curva de retenção do solo compactado no teor de umidade ótimo é representativa também para o solo compactado com 12,8\% de umidade. Na Figura 5.2 (b), estes dados são apresentados como uma curva de grau de saturação $v s$ sucção matricial, juntamente com os dados de retenção obtidos para o solo indeformado. A estes dados foi ajustado o modelo de Fredlund e Xing (1994) mostrado na Eq. 2.4. Os parâmetros dos ajustes são mostrados na Tabela 5.2, juntamente com os coeficientes de determinação $\left(r^{2}\right)$. Observa-se nesta tabela que os ajustes foram realizados em dois trechos para cada curva de retenção, com a finalidade melhor representar a distribuição multimodal dos poros deste solo.

Tabela 5.1. Índices físicos médios de moldagem dos corpos de prova para curvas de retenção de água.

\begin{tabular}{ccccc}
\hline \hline Amostra & $w(\%)$ & $\rho_{d}\left(\mathrm{~g} / \mathrm{cm}^{3}\right)$ & $S_{r}(\%)$ & $e$ \\
\hline Compactada & 12,8 & 1,710 & 62,0 & 0,549 \\
Compactada & 13,8 & 1,715 & 66,8 & 0,545 \\
Indeformada & 15,6 & 1,310 & 40,6 & 1,026 \\
\hline \hline
\end{tabular}

$\rho_{d}$ é a massa específica seca e $e$ é o índice de vazios.

Tal distribuição foi confirmada em ensaios de porosimetria por intrusão de mercúrio executados em amostras compactadas e indeformadas, como mostram as Figuras 5.3 e 5.4. Os resultados para o solo indeformado foram reproduzidos de Fernandes (2011). A porosimetria mostra elevados volumes acumulados de poros em torno de 0,015 e $50 \mu \mathrm{m}$ de diâmetro e relativamente baixos volumes quando os dados se afastam destes valores. Esta configuração de poros indica a existência de macro e microporos predominantes no solo, sendo estes associados a diâmetros médios de 50 e $0,015 \mu \mathrm{m}$, respectivamente. Os primeiros correspondem aos vazios formados por uma estrutura granular onde a fração fina do solo se agrega às partículas de areia. Já os últimos correspondem aos vazios no interior destas estruturas granulares. A Figura 5.4 sugere ainda que a desagregação do solo indeformado e posterior compactação pouco afetam os microporos do solo, sendo seu efeito predominante na formação dos macroporos. 


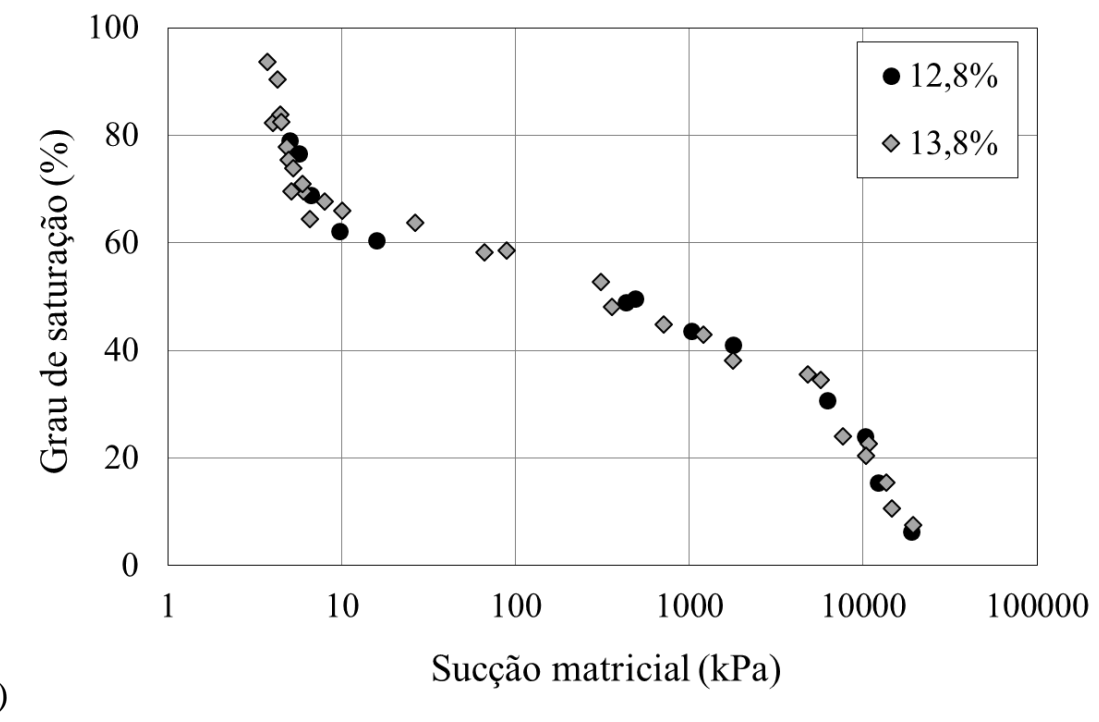

(a)

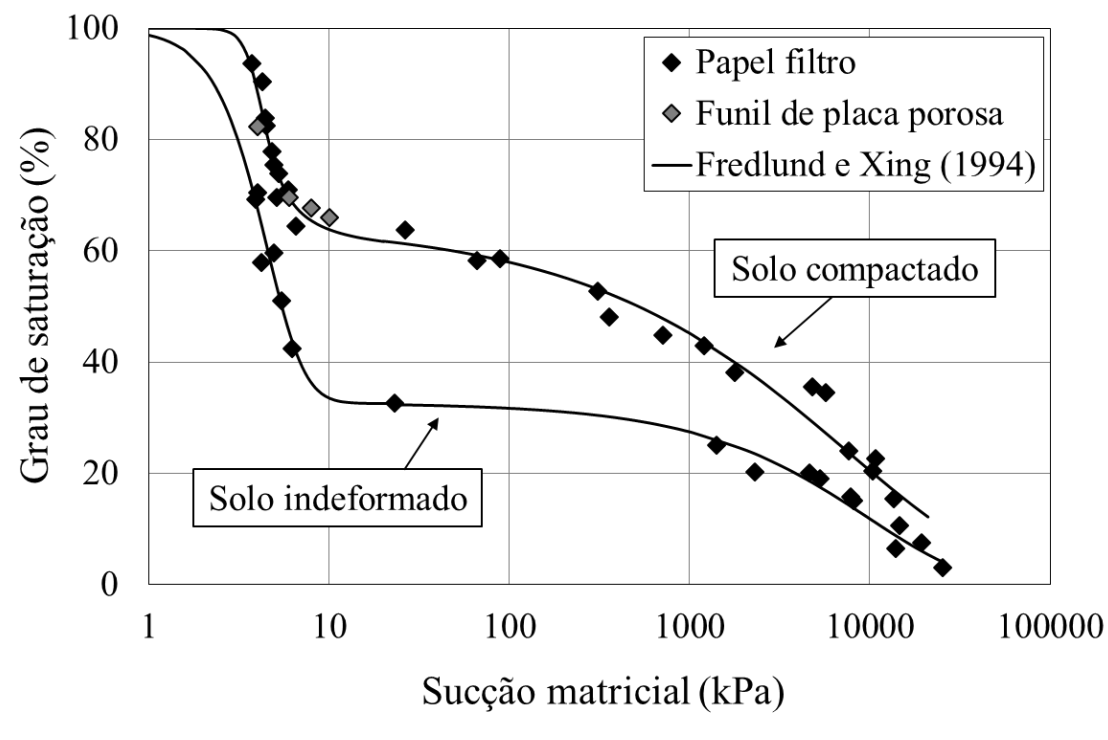

Figura 5.2. Curvas de retenção de água para (a) solo compactado em diferentes teores de umidade, e (b) solo compactado e indeformado.

Tabela 5.2. Parâmetros de ajuste das curvas de retenção ao modelo de Fredlund e Xing (1994).

\begin{tabular}{ccccccc}
\hline \hline Amostra & $a_{1}(\mathrm{kPa})$ & $n_{1}$ & $m_{1}$ & $S_{r s}$ & $S_{r r}$ & $r^{2}$ \\
\hline Compactada & 3,88 & 9,10 & 0,95 & 100,0 & 58,6 & 0,91 \\
$\left(w_{\text {ot }}=13,8 \%\right)$ & $7,82.10^{11}$ & 0,50 & $2,83.10^{4}$ & 65,0 & 0,0 & 0,96 \\
& 6,92 & 2,63 & 8,14 & 100,0 & 32,6 & 0,98 \\
Indeformada & $1,96.10^{9}$ & 0,77 & $3,16.10^{4}$ & 32,7 & 0,0 & 0,96 \\
\hline \hline
\end{tabular}

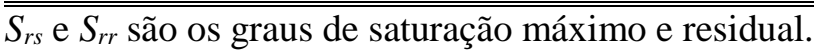


Sobre os efeitos da distribuição dos poros na curva de retenção de água, mais rápida drenagem é observada quando um grande volume de poros possui diâmetro similar e vice-versa. É possível notar ainda a ocorrência de dois valores distintos de entrada de ar em cada curva de retenção, sendo a entrada de ar dos macroporos mais pronunciada. Os modelos ajustados indicam esta primeira entrada de ar para pressões em torno de $3 \mathrm{kPa}$ para o solo compactado e $2 \mathrm{kPa}$ para o solo indeformado. Valores de mesma ordem de grandeza também foram obtidos por Feuerharmel (2003), Fernandes (2011) e Vilar e Rodrigues (2011) em solo indeformado e por Freitas Neto (2008) em solo compactado. A rápida drenagem de água após a entrada de ar é típica de solos arenosos, já que estes possuem relativamente grandes poros.

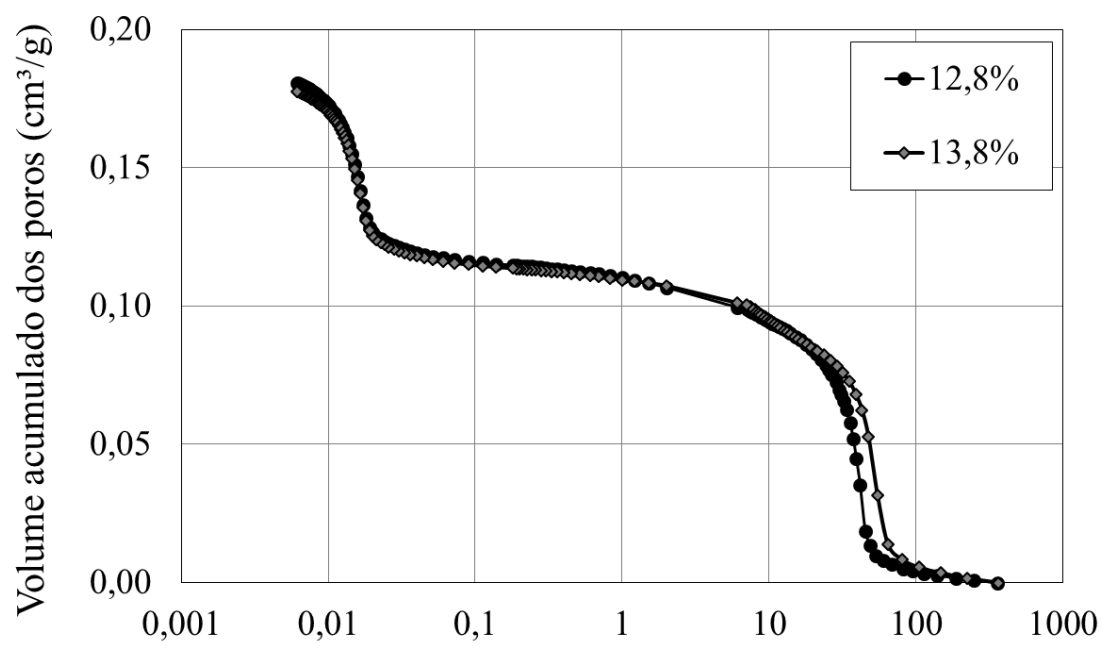

(a)

Diâmetro dos poros $(\mu \mathrm{m})$

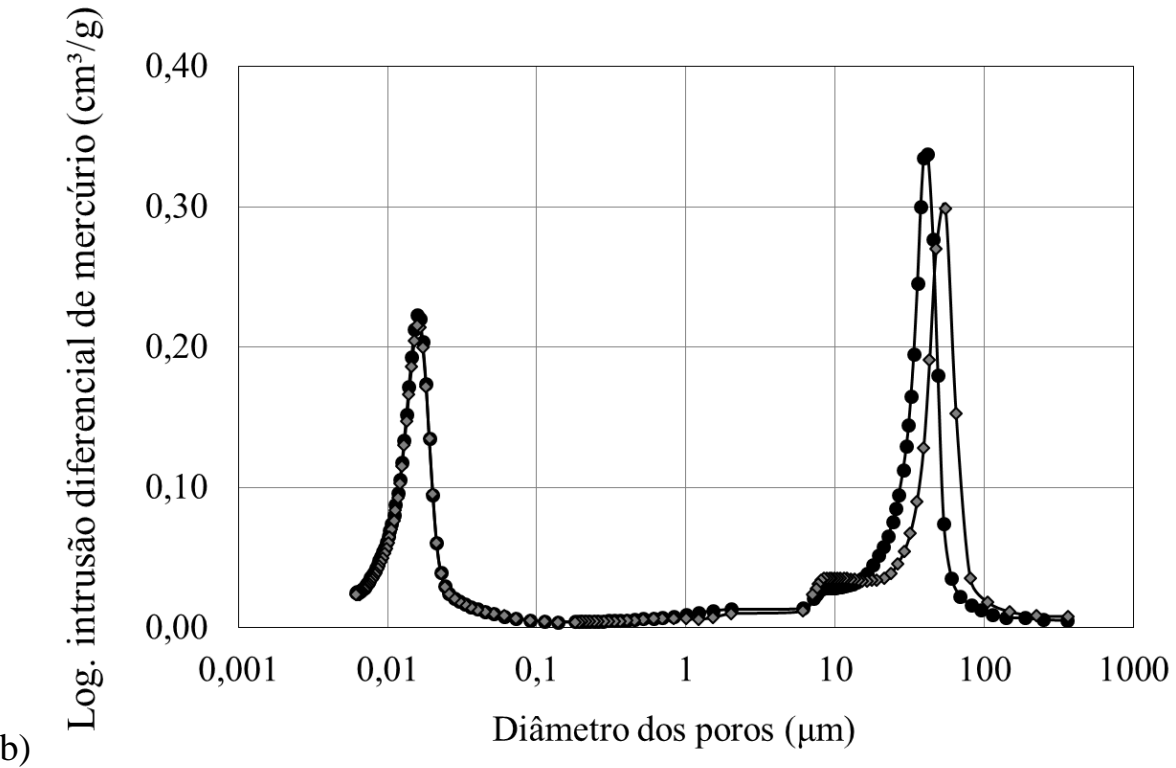

Figura 5.3. Porosimetria do solo compactado em diferentes teores de umidade. 


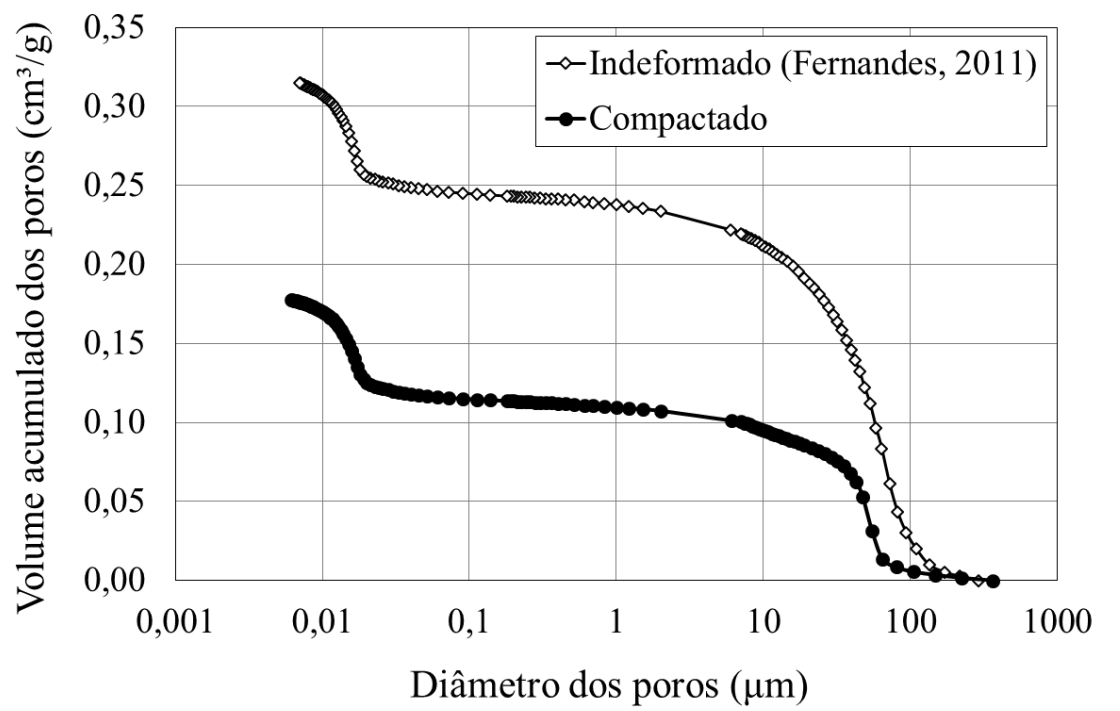

(a)

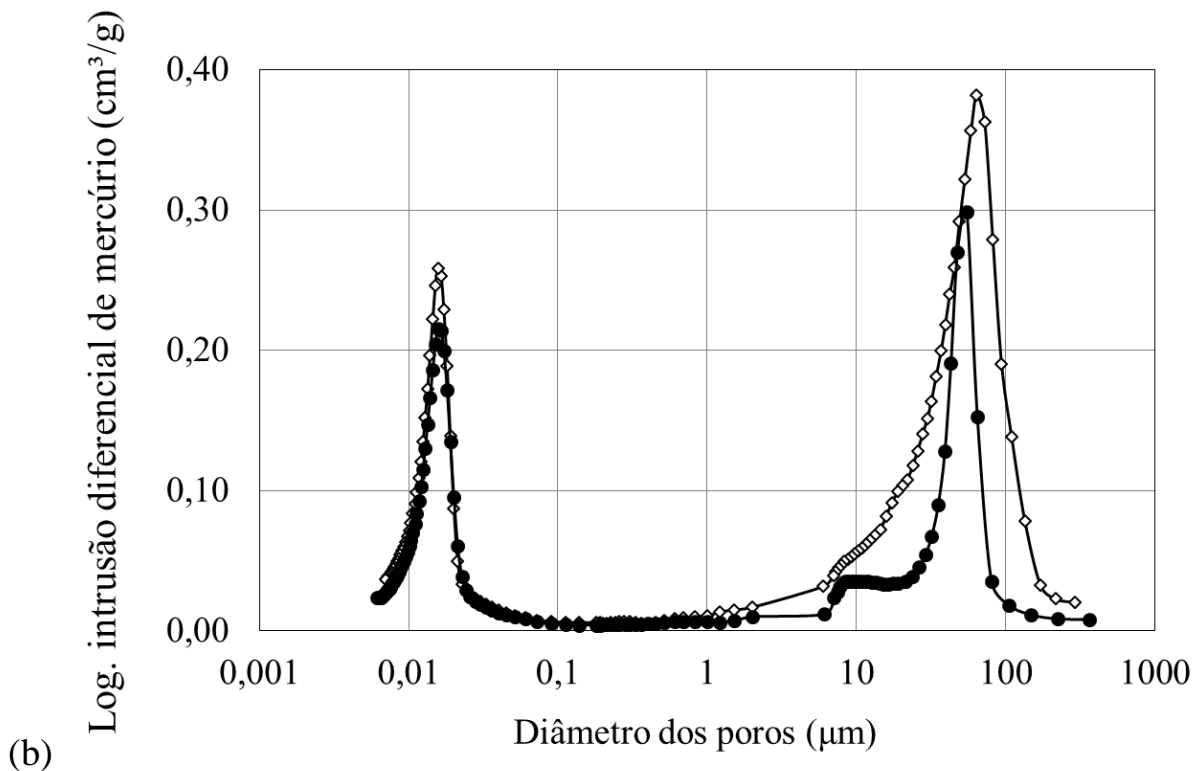

Figura 5.4. Porosimetria do solo compactado e indeformado.

\subsection{ENSAIOS DE RESISTÊNCIA AO CISALHAMENTO}

\subsubsection{Solo saturado}

Para os ensaios de resistência ao cisalhamento com solo saturado foram usados corpos de prova compactados com teor de umidade médio ( $w_{\text {médio }}$ ) de $13,8 \%$ e talhados a partir de bloco indeformado. Os índices físicos dos corpos de prova são mostrados na Tabela 5.3, assim como o tipo de amostra e condição de ensaio. 
Tabela 5.3. Índices físicos de moldagem dos corpos de prova para ensaio de resistência ao cisalhamento em condição saturada.

\begin{tabular}{|c|c|c|c|c|c|c|}
\hline Amostra & Ensaio & $\left(\sigma_{3}-u_{w}\right)_{\mathrm{c}}(\mathrm{kPa})$ & $w(\%)$ & $\rho_{d}\left(\mathrm{~g} / \mathrm{cm}^{3}\right)$ & $S_{r}(\%)$ & $e$ \\
\hline \multirow{4}{*}{$\begin{array}{c}\text { Compactada } \\
w_{\text {médio }}=13,8 \%\end{array}$} & \multirow{4}{*}{$\mathrm{CU}$} & 50 & 14,0 & 1,705 & 67,2 & 0,549 \\
\hline & & 150 & 13,9 & 1,706 & 67,1 & 0,548 \\
\hline & & 300 & 13,6 & 1,711 & 66,4 & 0,543 \\
\hline & & 500 & 13,6 & 1,706 & 65,7 & 0,548 \\
\hline \multirow{5}{*}{$\begin{array}{c}\text { Compactada } \\
w_{\text {médio }}=13,8 \%\end{array}$} & \multirow{5}{*}{$\mathrm{CD}$} & 50 & 13,9 & 1,716 & 67,9 & 0,538 \\
\hline & & 100 & 13,8 & 1,723 & 64,8 & 0,532 \\
\hline & & 150 & 13,8 & 1,718 & 67,7 & 0,537 \\
\hline & & 300 & 13,7 & 1,704 & 65,8 & 0,550 \\
\hline & & 500 & 13,6 & 1,709 & 66,1 & 0,545 \\
\hline \multirow{2}{*}{ Indeformada } & \multirow{2}{*}{$\mathrm{CD}$} & $20 / 100 / 400$ & 12,2 & 1,339 & 33,2 & 0,972 \\
\hline & & $50 / 200$ & 12,1 & 1,303 & 31,1 & 1,027 \\
\hline
\end{tabular}

$\left(\sigma_{3}-u_{w}\right)_{\mathrm{c}}$ é a tensão confinante líquida na fase de adensamento.

As Figuras 5.5 a 5.7 mostram as medidas realizadas durante o adensamento, com exceção dos dados do ensaio CU com tensão confinante líquida de $50 \mathrm{kPa}$ e CD com confinante de 100 $\mathrm{kPa}$, nos quais ocorreram problemas durante a aquisição de dados. As curvas apresentadas encontram-se referenciadas à tensão confinante líquida da fase de adensamento. Neste trabalho, as variações volumétricas $(\Delta V)$ e as deformações volumétricas $\left(\varepsilon_{v}\right)$ são positivas no sentido de redução do volume do corpo de prova.

A Figura 5.5 apresenta medidas de variação de volume feitas tanto na drenagem de água intersticial localizada na base do corpo de prova, quanto medidas feitas pelo fluxo de água na drenagem da câmara interna da câmara triaxial de parede dupla. Considerando que o solo possui grau de saturação de $100 \%$ na fase de adensamento, espera-se que as medidas apresentadas na Figura 5.5 sejam da mesma ordem de grandeza, já que ambas são tomadas como medidas da variação de volume total dos corpos de prova. No entanto, observa-se que para raiz quadrada do tempo superior a 2 , as variações de volume para um mesmo ensaio divergem entre si, o que é atribuído a variações de temperatura no ambiente de ensaio, como se elucida no item 5.2.2. Com isso, as medidas realizadas na drenagem da câmara interna, que são afetadas por tais oscilações de temperatura, são consideradas menos confiáveis e somente as medidas na drenagem dos corpos de prova são mostradas nas Figuras 5.6 e 5.7. 

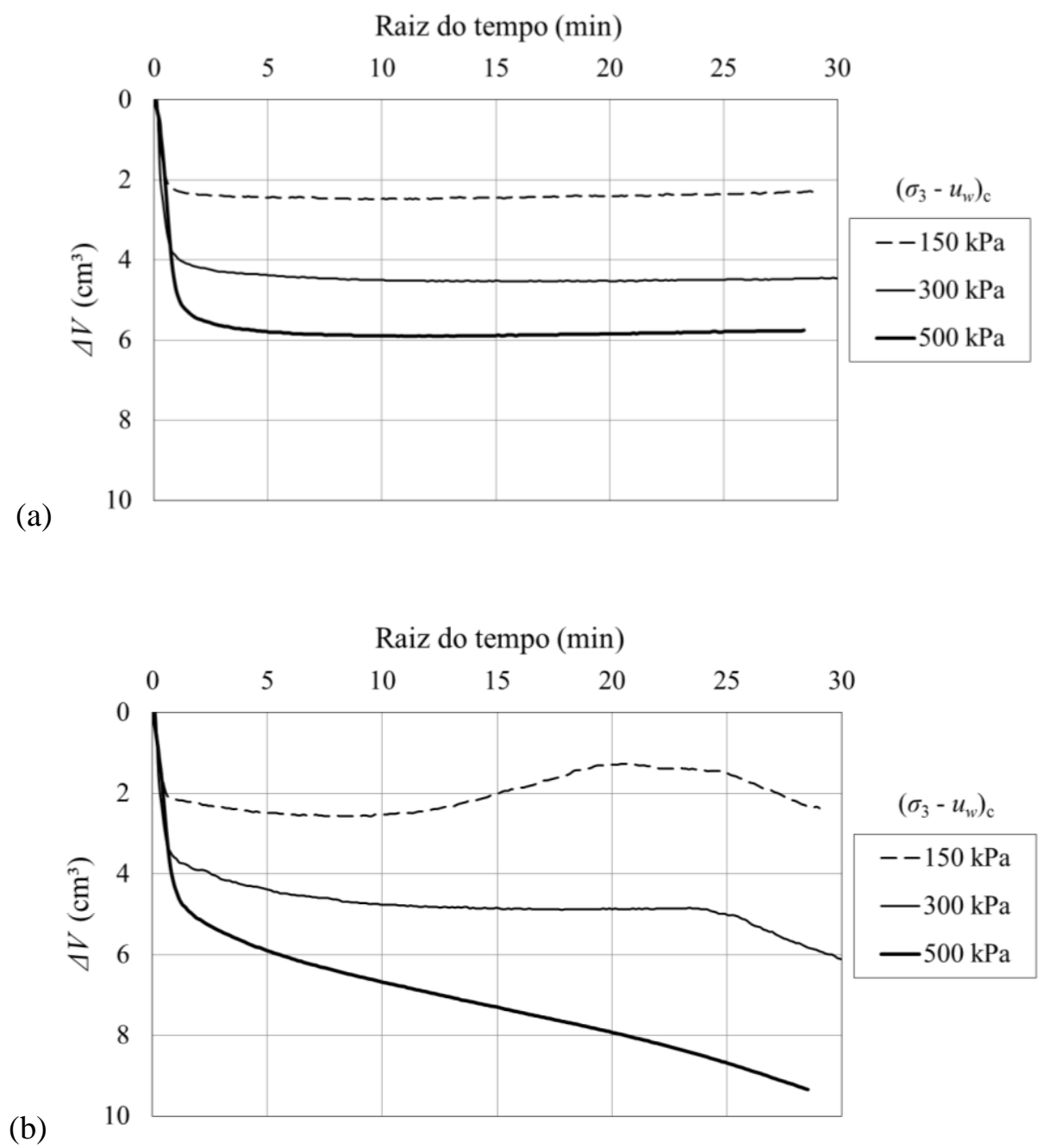

Figura 5.5. Curvas de adensamento dos ensaios CU com solo compactado: (a) medidas na drenagem do corpo de prova e (b) da câmara interna.

As curvas de adensamento isotrópico dos ensaios com solo saturado mostram-se razoavelmente coerentes, pois as Figuras 5.5 (a) e 5.6 apresentam no geral variações de volume de mesma magnitude e crescentes com a tensão confinante líquida. Já as variações de volume dos ensaios com amostra indeformada e $\left(\sigma_{3}-u_{w}\right)_{c}$ de 20 e $50 \mathrm{kPa}$, que são os primeiros estágios de cada ensaio, são maiores do que as variações registradas para o ensaio com $\left(\sigma_{3}-u_{w}\right)_{c}$ de 50 kPa em solo compactado. Este comportamento é coerente com a diferença de índice de vazios inicial dos corpos de prova compactado e indeformados. Para os estágios subsequentes dos ensaios com amostra indeformada, as variações de volume são função da tensão confinante aplicada em estágio anterior e também das deformações provenientes da etapa de cisalhamento anterior. Quanto ao tempo necessário para completar o adensamento dos corpos de prova, notase que para raiz do tempo igual a 5, a variação de volume do solo já está praticamente estabilizada, o que decorre da granulometria arenosa do solo em estudo. 


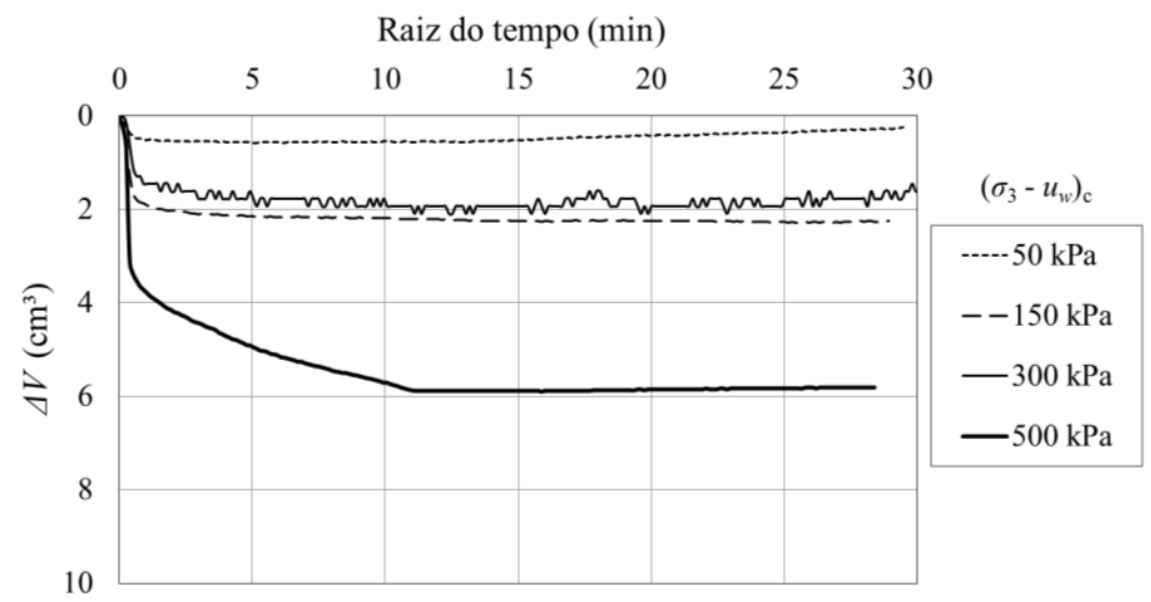

Figura 5.6. Curvas de adensamento dos ensaios CD com solo compactado: medidas na drenagem do corpo de prova.

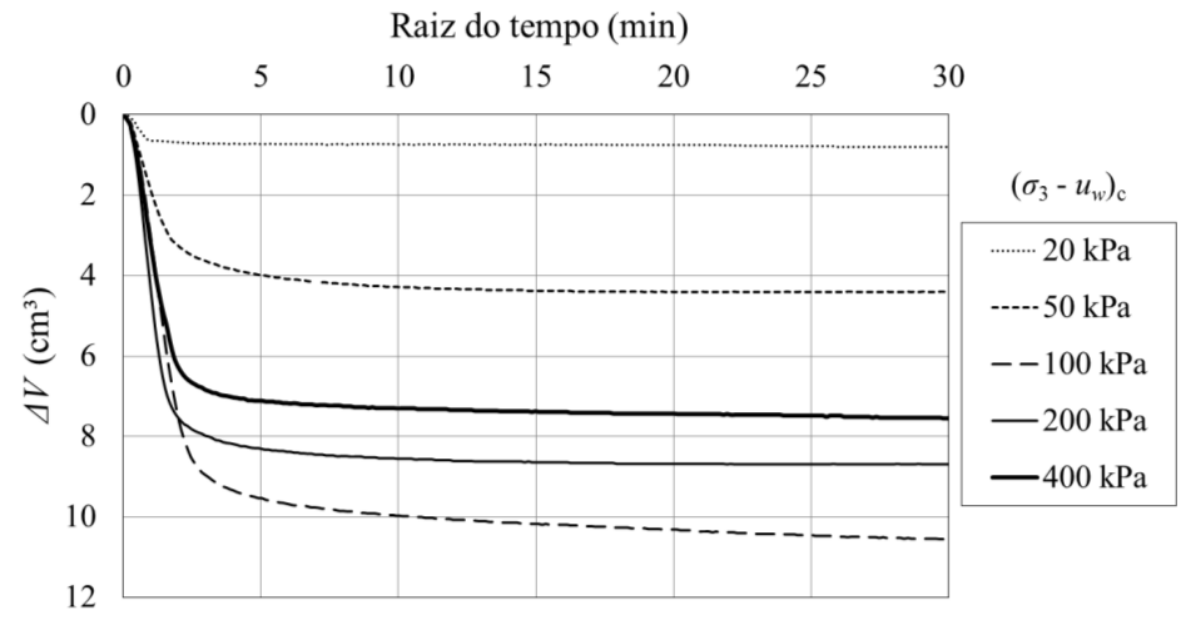

Figura 5.7. Curvas de adensamento dos ensaios $\mathrm{CD}$ com solo indeformado: medidas na drenagem do corpo de prova.

Da fase de ruptura dos ensaios de compressão triaxial, as curvas tensão $v s$ deformação axial $\left(\varepsilon_{a}\right)$, desenvolvimento de pressão neutra $\left(u_{w}\right)$ e deformações volumétricas, bem como as envoltórias de resistência ao cisalhamento são mostradas nas Figuras 5.8 a 5.18.

$\mathrm{Na}$ Figura 5.8, onde a tensão é representada por $\sigma_{1}-\sigma_{3}$, as curvas tensão e pressão neutra vs deformação axial dos ensaios CU estão de acordo com a teoria de Mecânica dos Solos, pois tanto a resistência quanto a pressão neutra aumentam no solo com a tensão confinante líquida de adensamento. Quando se comparam as Figuras 5.8 e 5.9, nota-se que na representação por $\sigma_{1}-\sigma_{3}$ a curva de tensão confinante líquida de $500 \mathrm{kPa}$ apresenta um pico de resistência, que diminui gradativamente para as menores confinantes líquidas. Já na representação por $\left(\sigma_{l}-u_{w}\right)$ 
$/\left(\sigma_{3}-u_{w}\right)$ somente para a tensão confinante líquida de $50 \mathrm{kPa}$ é que o pico de resistência acontece, o que provavelmente se justifica pelo formato da curva de pressão neutra (Figura 5.10), que influencia na relação $\left(\sigma_{1}-u_{w}\right) /\left(\sigma_{3}-u_{w}\right)$. Os gráficos de pressão neutra justificam ainda o posicionamento relativo das curvas $\left(\sigma_{1}-u_{w}\right) /\left(\sigma_{3}-u_{w}\right) v s$ deformação axial. Na Figura 5.10, o ensaio com $300 \mathrm{kPa}$ de confinante, por exemplo, tem sua pressão neutra equilibrada em aproximadamente $250 \mathrm{kPa}$, que é mais que o dobro da pressão neutra de equilíbrio no ensaio de tensão confinante de $150 \mathrm{kPa}$. Este comportamento reflete no aumento da relação $\left(\sigma_{l}-u_{w}\right)$ $/\left(\sigma_{3}-u_{w}\right)$ para a confinante de $300 \mathrm{kPa}$ em comparação com a confinante de $150 \mathrm{kPa}$.

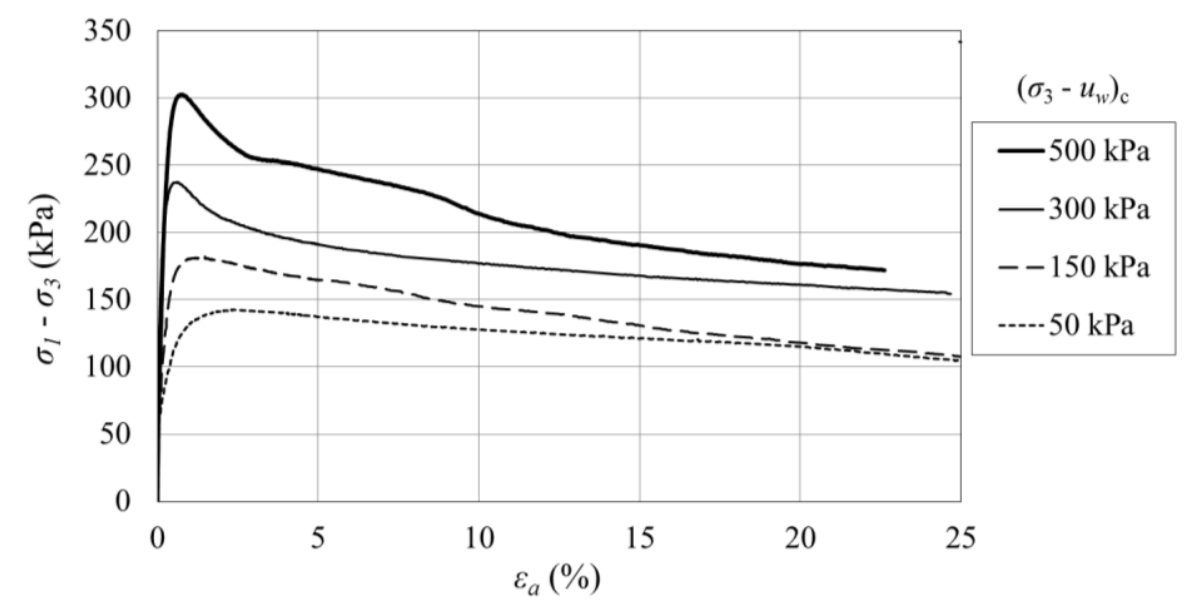

Figura 5.8. Curvas $\left(\sigma_{l}-\sigma_{3}\right)$ vs deformação axial dos ensaios CU com solo saturado compactado.

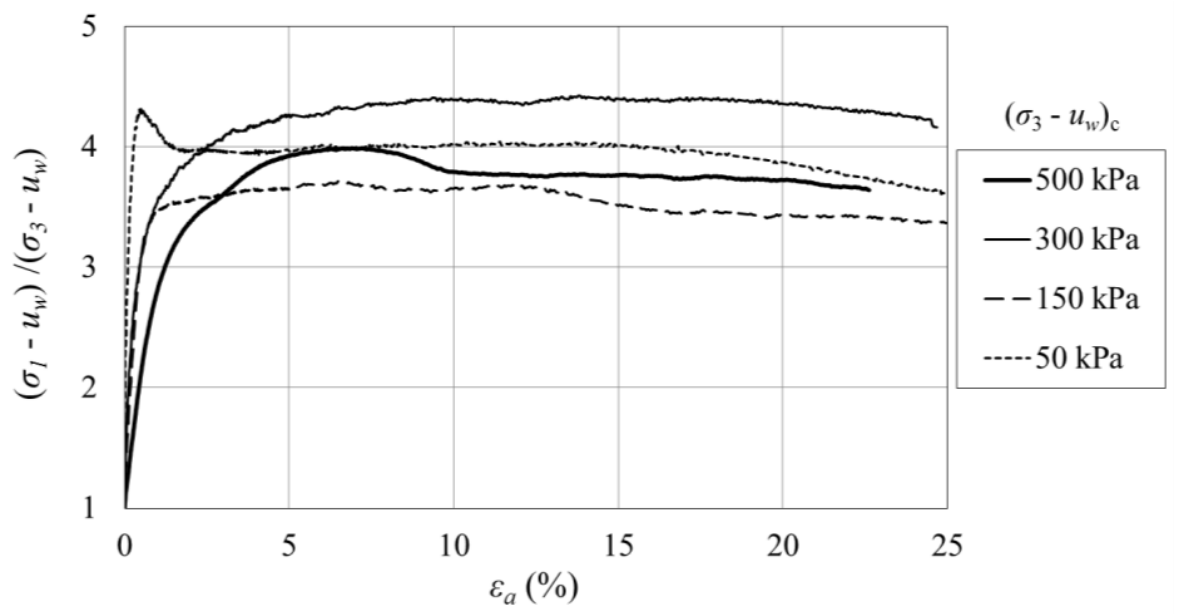

Figura 5.9. Curvas $\left(\sigma_{1}-u_{w}\right) /\left(\sigma_{3}-u_{w}\right) v s$ deformação axial dos ensaios CU com solo saturado compactado. 


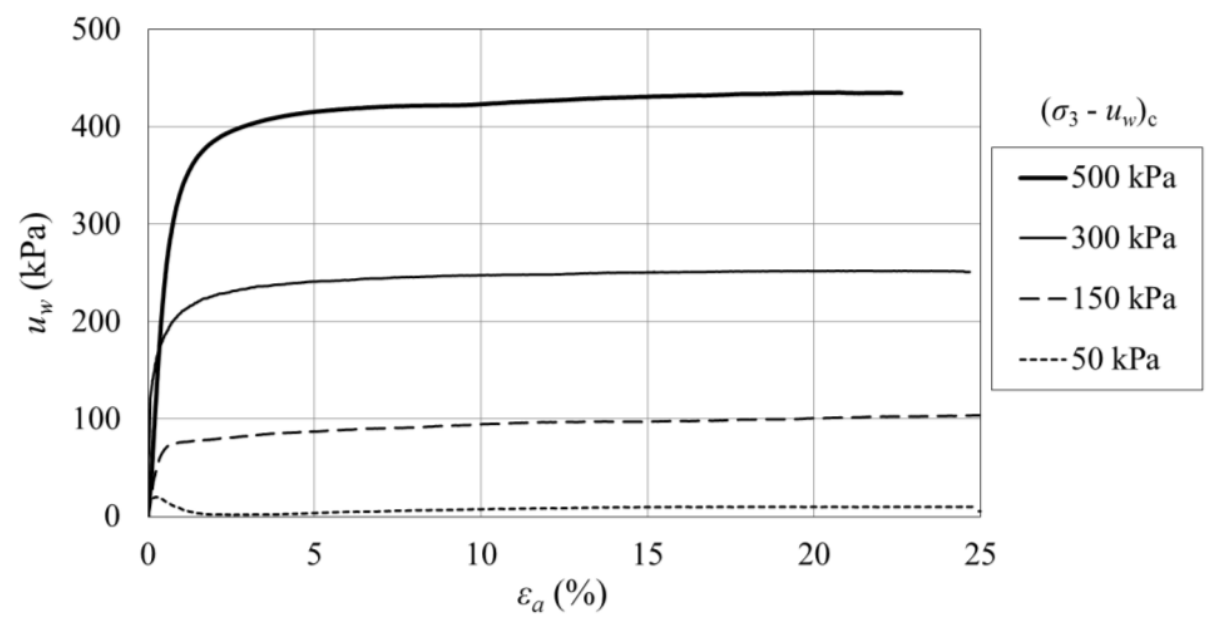

Figura 5.10. Pressões neutras nos ensaios CU com solo saturado compactado.

Ao final dos ensaios, todos os corpos de prova compactados submetidos a ensaios não drenados mostraram a formação de plano de ruptura com inclinação média de $60^{\circ}$. Esta inclinação indica um ângulo de atrito efetivo $(\phi ’)$ em torno de $30^{\circ}$. Já das envoltórias de resistência ao cisalhamento dos ensaios não drenados para as curvas $\sigma_{1}-\sigma_{3} \mathrm{e}\left(\sigma_{1}-u_{w}\right) /\left(\sigma_{3}-u_{w}\right)$, obtiveram-se $\phi{ }^{\prime}$ de $20^{\circ}$ e $35^{\circ}$ e coesão efetiva ( $\left.c^{\prime}\right)$ de 38 e $5 \mathrm{kPa}$, respectivamente, ambas com coeficiente de determinação superior a 0,97. Assim, para os ensaios CU realizados nesta pesquisa, a envoltória linear de resistência efetiva ajustada aos máximos de $\left(\sigma_{1}-u_{w}\right) /\left(\sigma_{3}-u_{w}\right)$ apresentou parâmetros de resistência mais coerentes com os planos de ruptura observados nos corpos de prova e com a envoltória determinada a partir dos ensaios CD com solo compactado saturado, que será mostrada mais adiante. A envoltória para as curvas $\left(\sigma_{1}-u_{w}\right) /\left(\sigma_{3}-u_{w}\right)$ é mostrada na Figura 5.11.

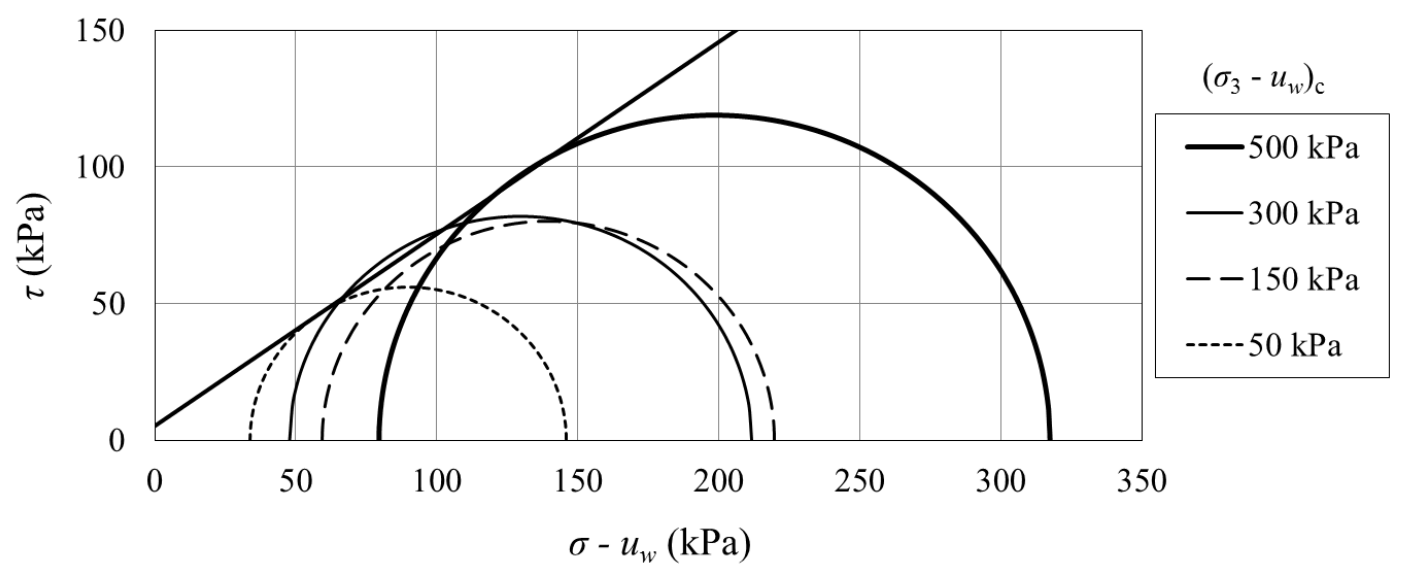

Figura 5.11. Envoltória de resistência ao cisalhamento em termos de tensões efetivas para a representação por $\left(\sigma_{l}-u_{w}\right) /\left(\sigma_{3}-u_{w}\right)$ dos ensaios CU com solo compactado saturado. 
Dos resultados dos ensaios CD, as Figuras 5.12 e 5.13 mostram-se coerentes à medida que a resistência ao cisalhamento e a deformação volumétrica dos corpos de prova na ruptura aumentam com a tensão confinante líquida de adensamento. Observa-se também que a deformação axial correspondente à resistência máxima aumentou com o aumento da tensão confinante. Em todos os casos a deformação volumétrica ocorreu no sentido de compressão do solo, não havendo registro de dilatância nem para a menor tensão confinante. A envoltória de resistência ao cisalhamento para os ensaios $\mathrm{CD}$ fornece ângulo de atrito efetivo de $33^{\circ}$ e coesão nula com coeficiente de determinação de 0,99 . A representação gráfica desta envoltória é apresentada na Figura 5.14.

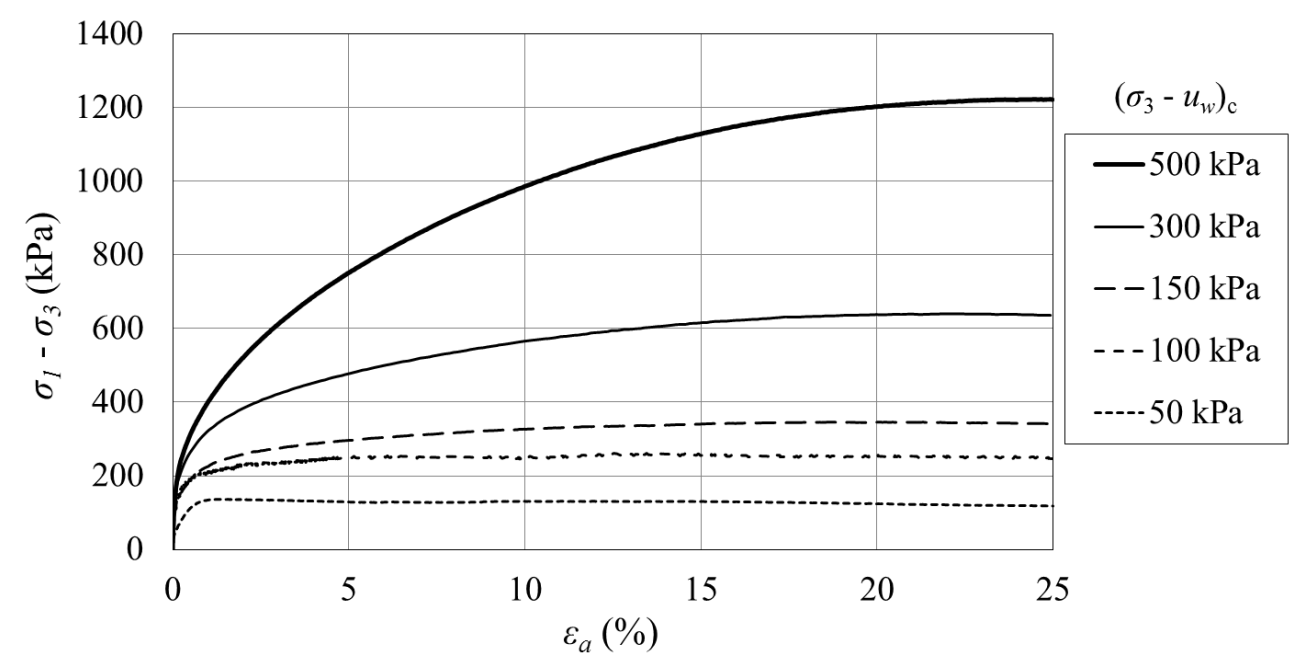

Figura 5.12. Curvas tensão vs deformação axial dos ensaios CD com solo saturado compactado.

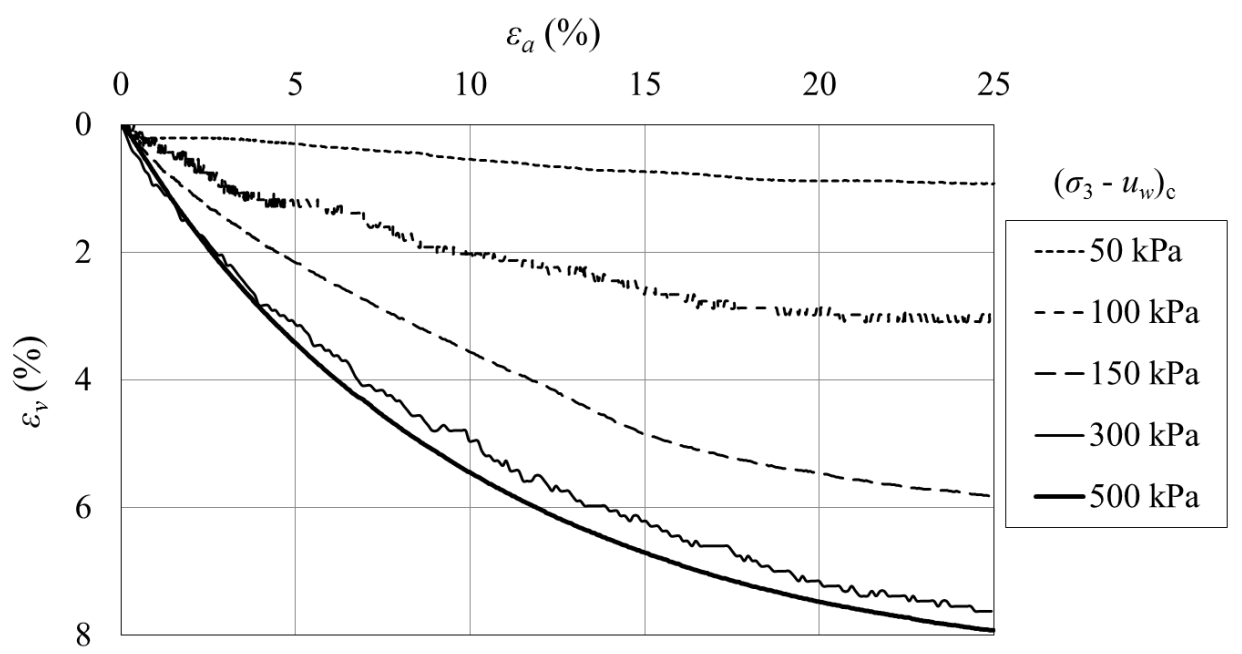

Figura 5.13. Deformações volumétricas nos ensaios CD com solo saturado compactado. 


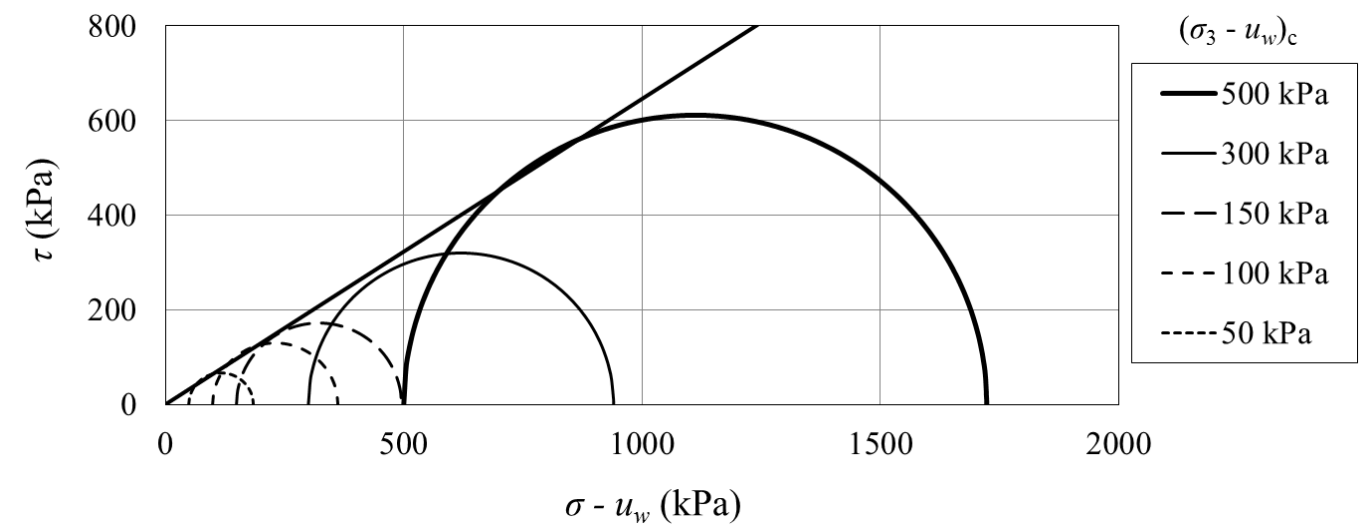

Figura 5.14. Envoltória de resistência ao cisalhamento dos ensaios CD com o solo compactado saturado.

Uma envoltória de resistência única, em termos de tensões efetivas, foi determinada para os ensaios CD e CU, e é mostrada na Figura 5.15. Os ensaios CU são representados pelos círculos de Mohr da Figura 5.11. Também na envoltória conjunta o coeficiente de determinação foi elevado $(0,99)$, mostrando coerência entre os ensaios realizados com solo compactado. Neste caso, o ângulo de atrito efetivo foi de $32^{\circ}$ e a coesão efetiva foi de $7 \mathrm{kPa}$.

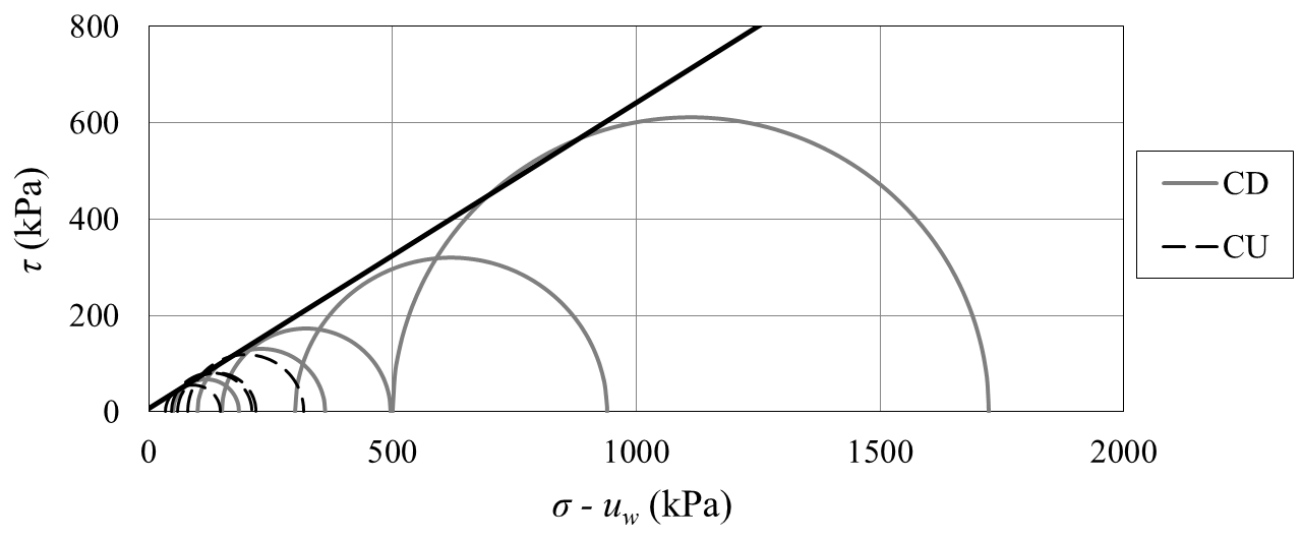

Figura 5.15. Envoltória de resistência ao cisalhamento para o solo compactado saturado considerando os ensaios $\mathrm{CD}$ e $\mathrm{CU}$ em conjunto.

Para o solo indeformado, as curvas tensão e deformação volumétrica vs deformação axial são mostradas nas Figuras 5.16 e 5.17. Os estágios com tensão confinante 50 e 100 kPa, por se tratarem de estágios intermediários, foram encerrados quando a deformação axial atingiu 10\%. Para este nível de deformação, a tensão tendia à estabilização, embora não se observasse constância ou decréscimo em seu valor. Nos demais estágios permitiram-se deformações até que a tensão se estabilizasse. Tanto as deformações axiais quanto as volumétricas foram calculadas com base nas dimensões dos corpos de prova no início de cada estágio. No que se 
refere às deformações volumétricas, todos os estágios mostraram redução de volume durante a ruptura, o que está de acordo com a elevada porosidade da amostra indeformada.

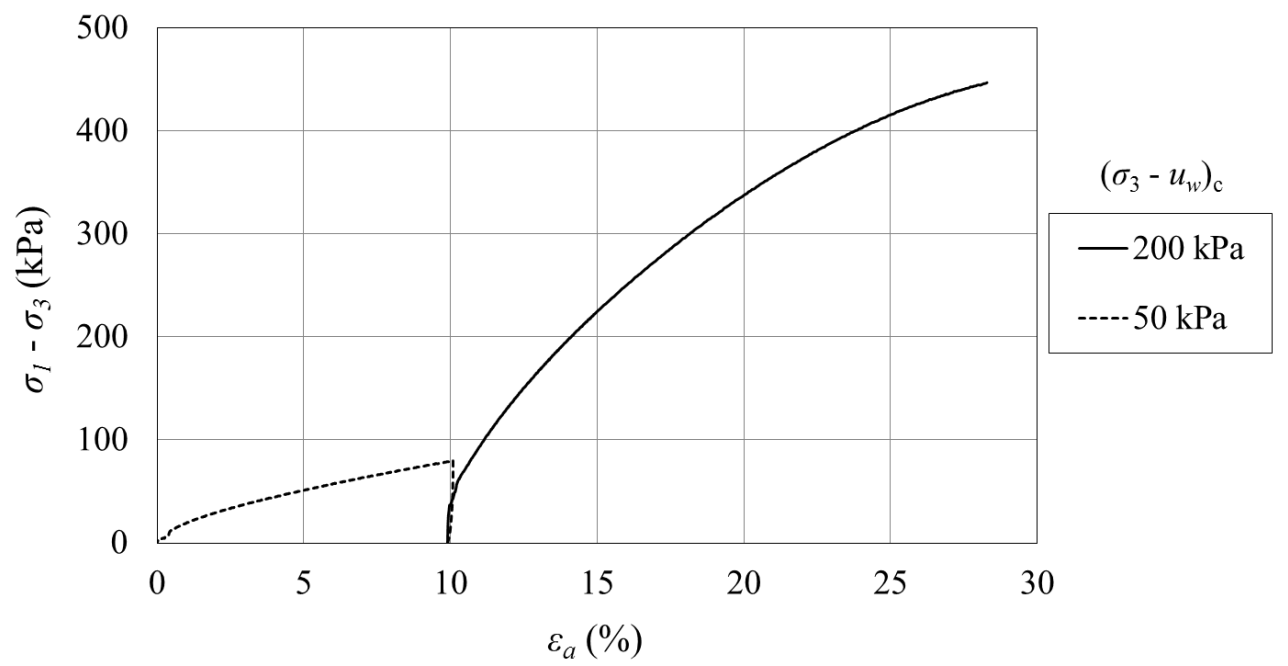

(a)

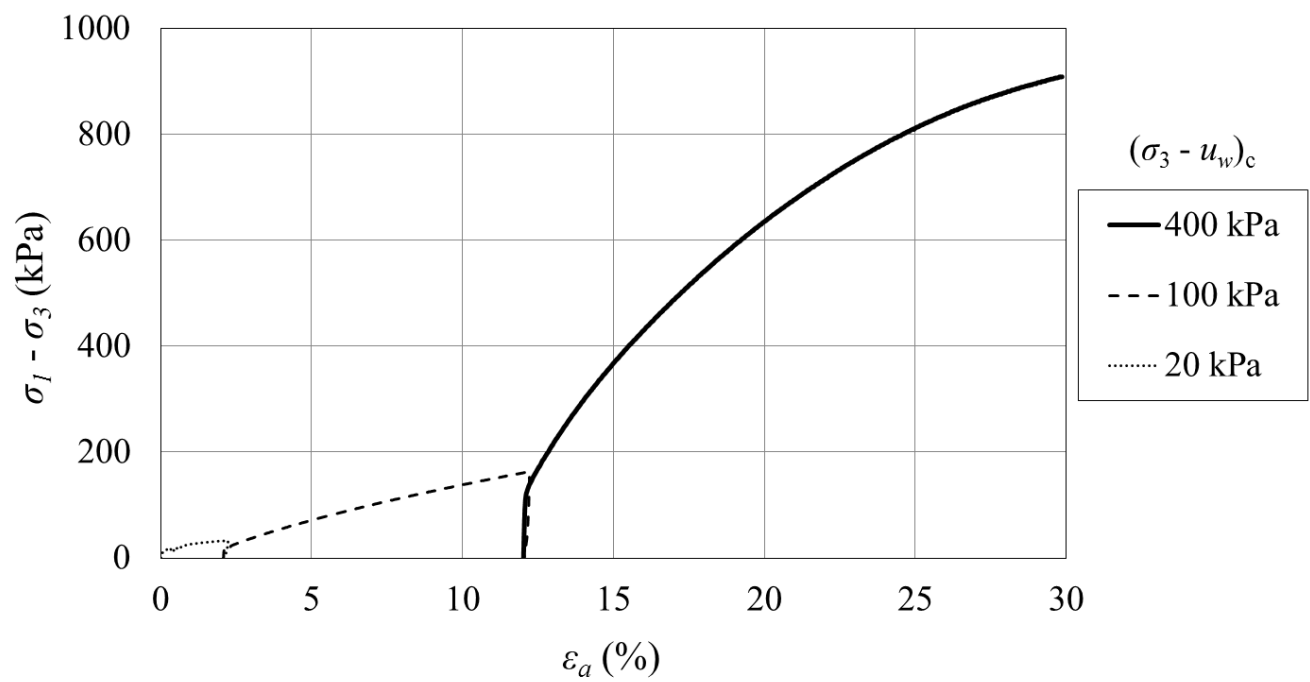

Figura 5.16. Curvas tensão vs deformação axial dos ensaios CD com solo saturado indeformado para tensões confinantes líquidas de (a) 50 e $200 \mathrm{kPa}$, e (b) 20, 100 e $400 \mathrm{kPa}$.

O ajuste de uma única envoltória aos dados experimentais forneceu coesão nula e ângulo de atrito efetivo de $32^{\circ}$ com coeficiente de determinação de 0,99 (Figura 5.18). Estes parâmetros de resistência são próximos aos encontrados para o solo compactado com grau de compactação de $95 \%$ e teor de umidade ótimo. 
(a)
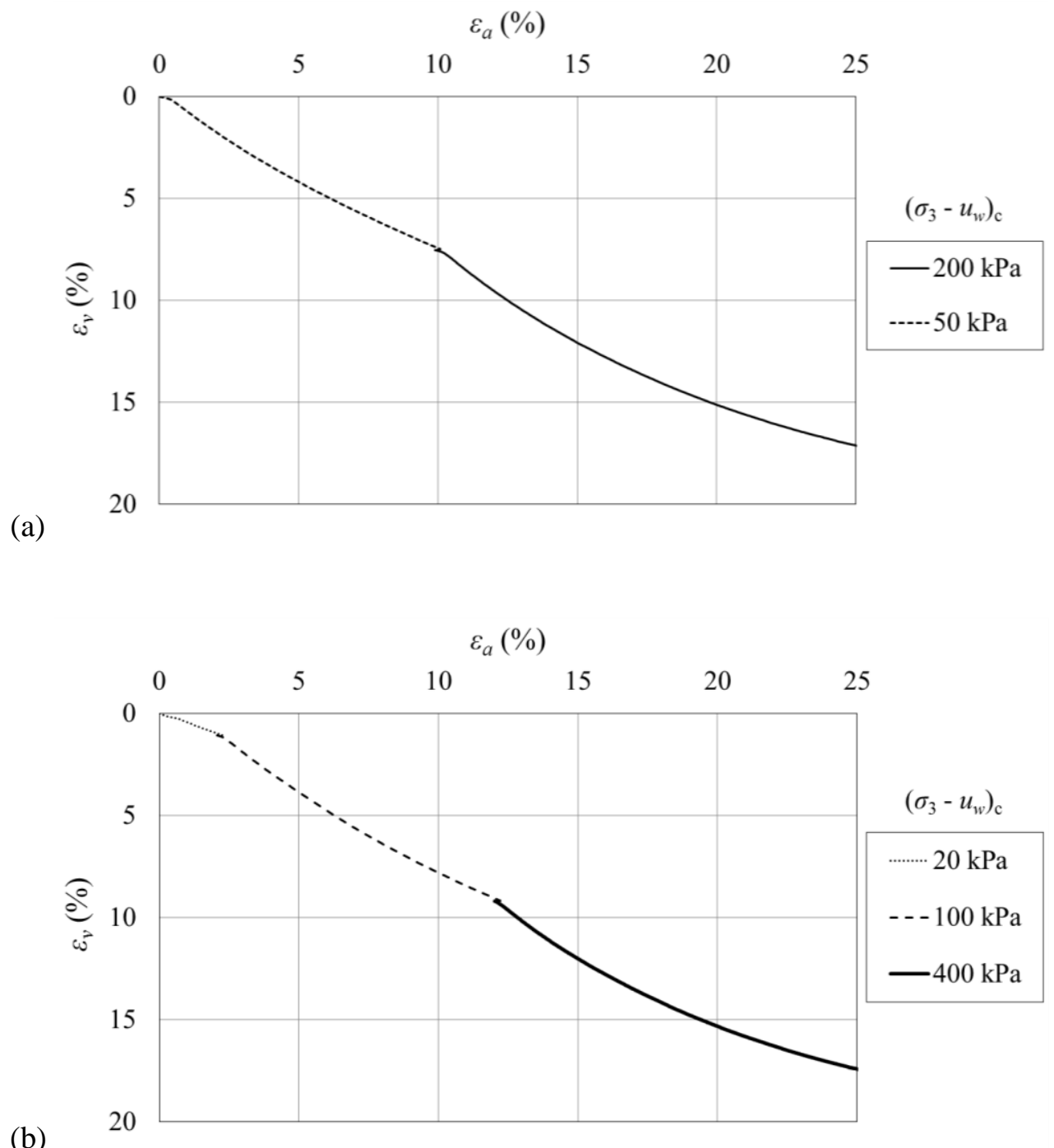

Figura 5.17. Deformações volumétricas nos ensaios CD com solo saturado indeformado para tensões confinantes líquidas de (a) 50 e $200 \mathrm{kPa}$, e (b) 20, 100 e $400 \mathrm{kPa}$.

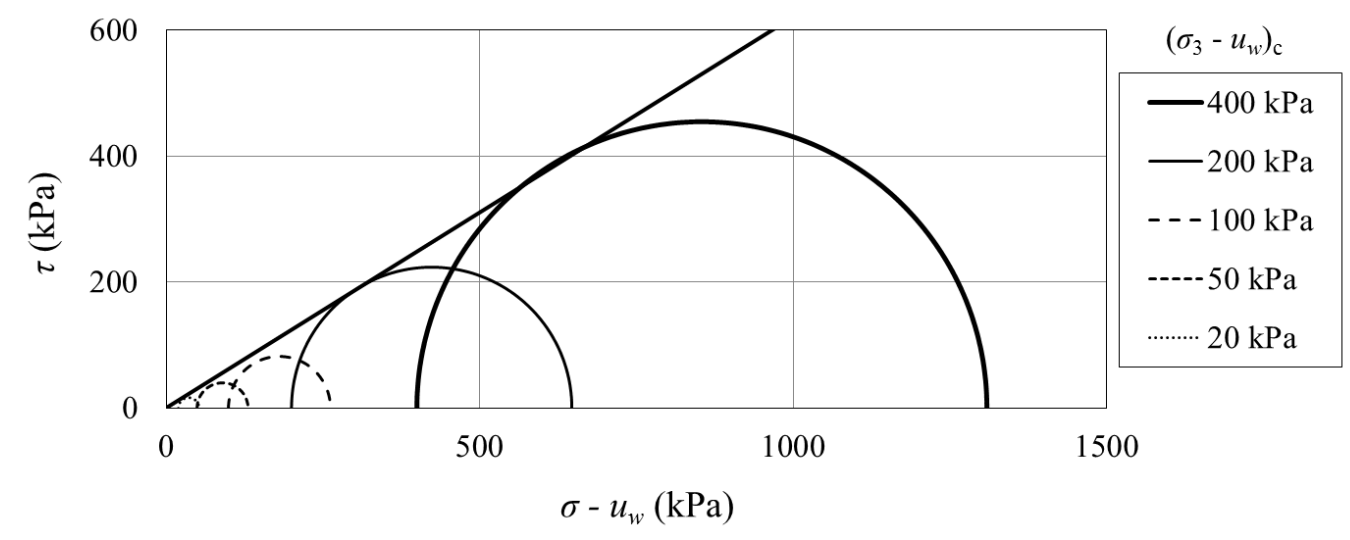

Figura 5.18. Envoltória de resistência ao cisalhamento para o solo indeformado saturado a partir de ensaios $\mathrm{CD}$. 


\subsubsection{Solo não saturado}

Os ensaios com solo não saturado foram realizados com corpos de prova compactados e indeformados, que tiveram sucção previamente imposta e foram ensaiados em múltiplos estágios com tensões confinantes líquidas de 50, 150, 300 e $500 \mathrm{kPa}$. Os corpos de prova foram levados à ruptura com teor de umidade constante. As características de moldagem e de ensaio destes corpos de prova são indicadas na Tabela 5.4.

Tabela 5.4. Índices físicos de moldagem dos corpos de prova para ensaio de resistência ao cisalhamento em condição não saturada.

\begin{tabular}{cccccc}
\hline \hline Amostra & $u_{a}-u_{w}$ imposta $(\mathrm{kPa})$ & $w(\%)$ & $\rho_{d}\left(\mathrm{~g} / \mathrm{cm}^{3}\right)$ & $S_{r}(\%)$ & $e$ \\
\hline \multirow{2}{*}{ Compactada } & 15 & 14,0 & 1,713 & 67,8 & 0,547 \\
$w_{\text {médio }}=13,9 \%$ & 40 & 13,8 & 1,712 & 66,6 & 0,548 \\
& 100 & 13,8 & 1,713 & 67,11 & 0,547 \\
\hline \multirow{3}{*}{ Indeformada } & 15 & 11,6 & 1,278 & 28,6 & 1,073 \\
& 40 & 12,2 & 1,283 & 30,2 & 1,065 \\
& 80 & 11,4 & 1,286 & 28,5 & 1,060 \\
\hline \hline
\end{tabular}

Durante as fases de adensamento isotrópico, medidas de variação de volume da água intersticial e de volume total do solo foram tomadas respectivamente na drenagem da base do corpo de prova e na drenagem da câmara interna. A Figura 5.19 mostra o comportamento das variações volumétricas para o solo compactado com sucção imposta de $15 \mathrm{kPa}$, de onde se avalia que as variações de volume de água e total do solo são respectivamente inferiores a $1 \%$ e $4 \%$ do volume inicial do corpo de prova. Notam-se, na Figura 5.19 (b), oscilações nas medidas de volume que são mais evidentes do que as mostradas na Figura 5.5 (b), o que acontece devido ao aumento do tempo de adensamento do corpo de prova com sucção para até 4 dias. Como critério de finalização do adensamento, foi observada a estabilização das leituras de variação de volume de água intersticial dos corpos de prova, tendo em vista que esta medida é menos influenciada pelas oscilações de temperatura no decorrer do ensaio.

A Figura 5.20 exemplifica a associação das oscilações de medidas de variação de volume na câmara interna com a temperatura do ambiente. As medidas de temperatura foram feitas em um reservatório de água posicionado ao lado da câmara de ensaio. A variação positiva de volume observada nesta figura está relacionada à saída de água do interior da câmara, o que pode refletir tanto a redução de volume total do corpo de prova quanto a contração da água devido a uma redução de temperatura. Por outro lado, uma variação negativa na medida de 
volume reflete a dilatação da água devido a um aumento na temperatura ambiente. Estes efeitos encontram-se defasados no tempo e setas foram utilizadas para indicar esta associação. $\mathrm{O}$ resultado da dilatação ou contração da água devido à temperatura é mais evidente nas medidas tomadas na drenagem da câmara interna (Figuras 5.19b e 5.20) devido ao elevado volume da câmara quando comparado ao sistema de drenagem pela base do corpo de prova (Figura 5.19a) e ao volume do próprio corpo de prova.

(a)

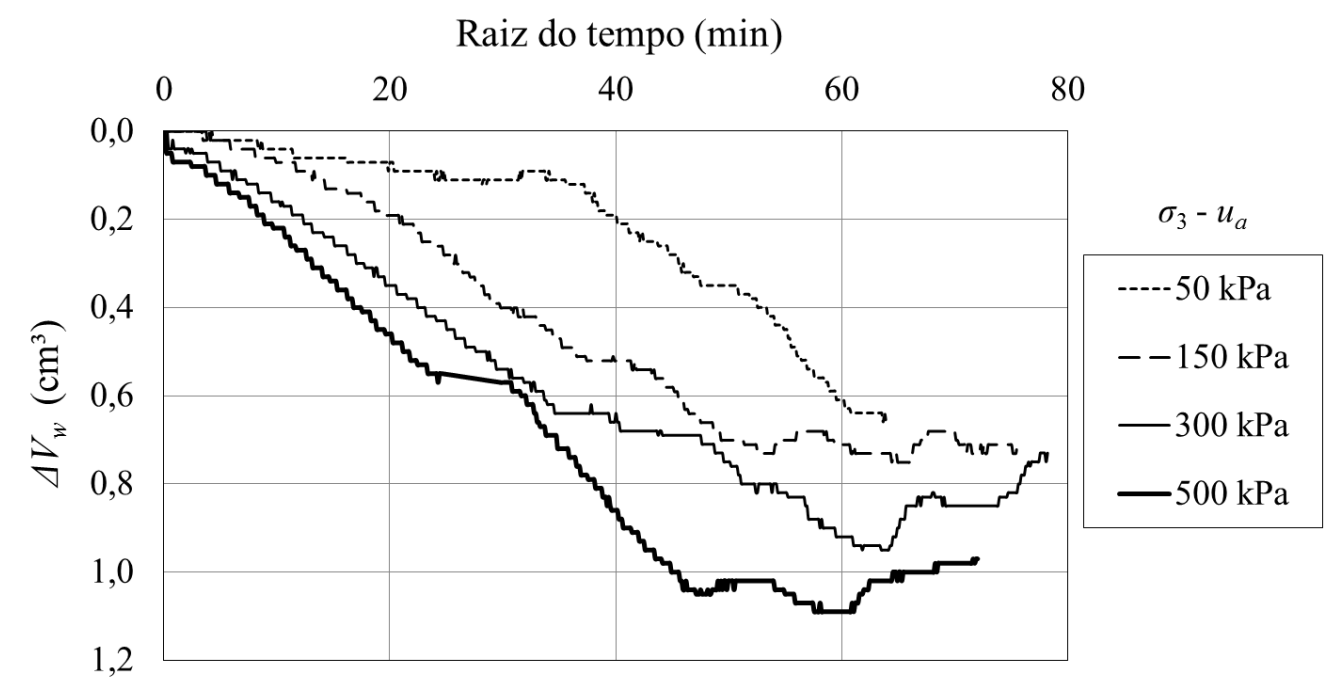

(b)

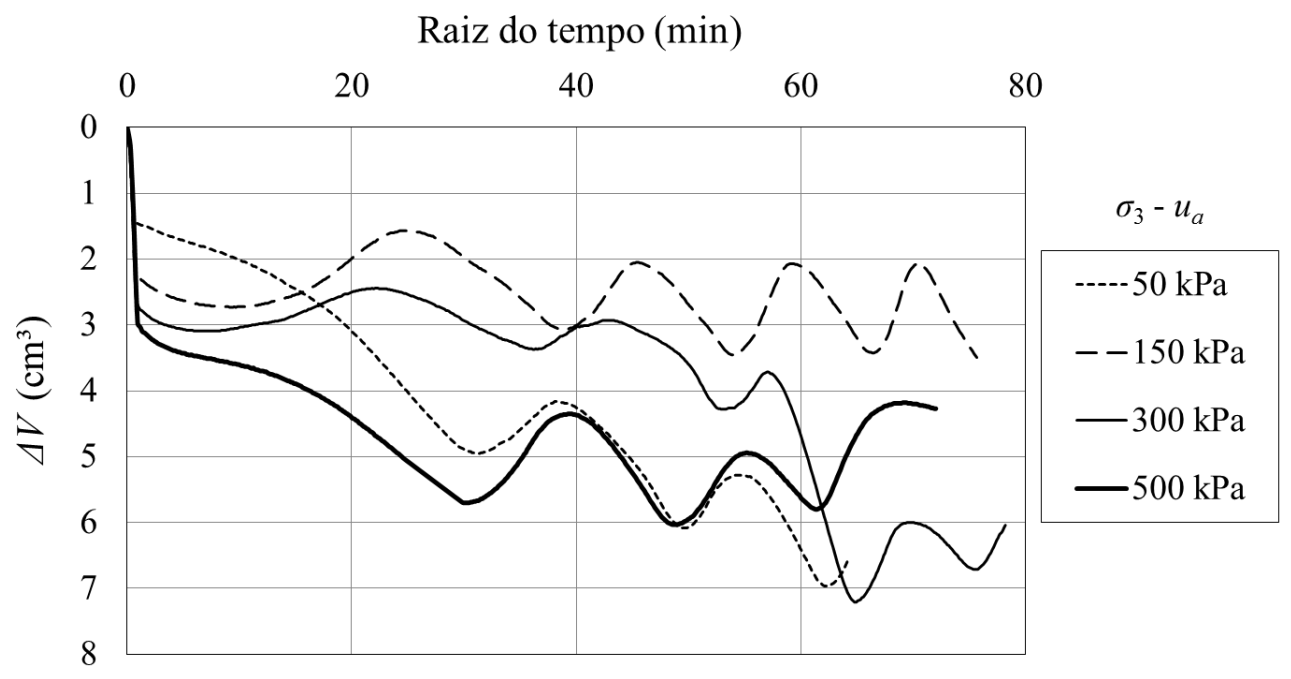

Figura 5.19. Curvas de adensamento do ensaio CW com solo compactado e sucção imposta de $15 \mathrm{kPa}$ :

(a) medidas na drenagem do corpo de prova e (b) da câmara interna.

Após cada etapa de adensamento, seguiu a etapa de estabilização da sucção do solo para início do cisalhamento, que consistiu no monitoramento da sucção até que se atingisse um equilíbrio, como exemplificado na Figura 5.21. Assumiu-se a etapa de estabilização da sucção 
finalizada quando a variação da sucção foi inferior a $5 \mathrm{kPa}$ em 24 horas, a sucção tendeu a um valor assintótico ou ainda quando a etapa de estabilização atingiu 5 dias de duração. Na Figura 5.21 são mostrados os dados dos corpos de prova compactado e indeformado submetidos à sucção de $40 \mathrm{kPa}$ e diferentes tensões confinantes líquidas. Observa-se em (a) que as menores tensões confinantes líquidas tendem a exibir menor variação da sucção neste estágio. Quando se comparam dados do solo compactado e indeformado (Figuras 5.21 a e b), é possível notar que menores variações em $u_{a}-u_{w}$ foram registradas quando o solo foi ensaiado em condição indeformada. As magnitudes de variação da sucção observadas estão possivelmente associadas com a porcentagem de adensamento que os corpos de prova atingiram durante a etapa de adensamento imediatamente anterior.

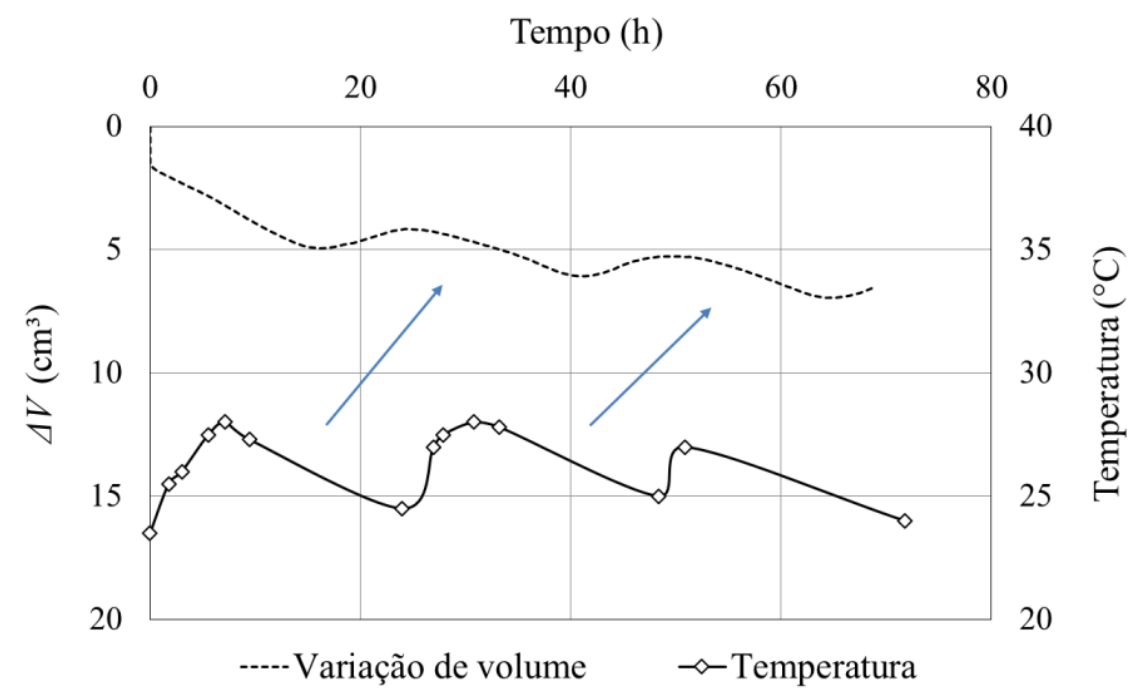

Figura 5.20. Curva de adensamento do ensaio CW com solo compactado, sucção imposta de $15 \mathrm{kPa}$ e confinamento líquido de $50 \mathrm{kPa}$ : efeito da variação de temperatura.

O comportamento deste solo durante o cisalhamento é exemplificado pelas Figuras 5.22 e 5.23 para amostras compactada e indeformada, respectivamente. Os estágios de cisalhamento duraram em torno de 20 horas cada e seus resultados são apresentados de maneira contínua, na sequência em que aconteceram nos ensaios. Nas Figuras 5.22 e 5.23, cada estágio de ruptura está referenciando à respectiva tensão confinante líquida $\left(\sigma_{3}-u_{a}\right)$.

As curvas tensão vs deformação mostram o solo se comportando à semelhança de um material plástico, com maior resistência à medida que aumenta a tensão confinante líquida e a sucção na ruptura. Especificamente, na Figura 5.23 (a) observa-se que o solo indeformado apresenta resistência continuamente crescente à medida que aumentam as deformações axiais, como em um tipo de encruamento. 


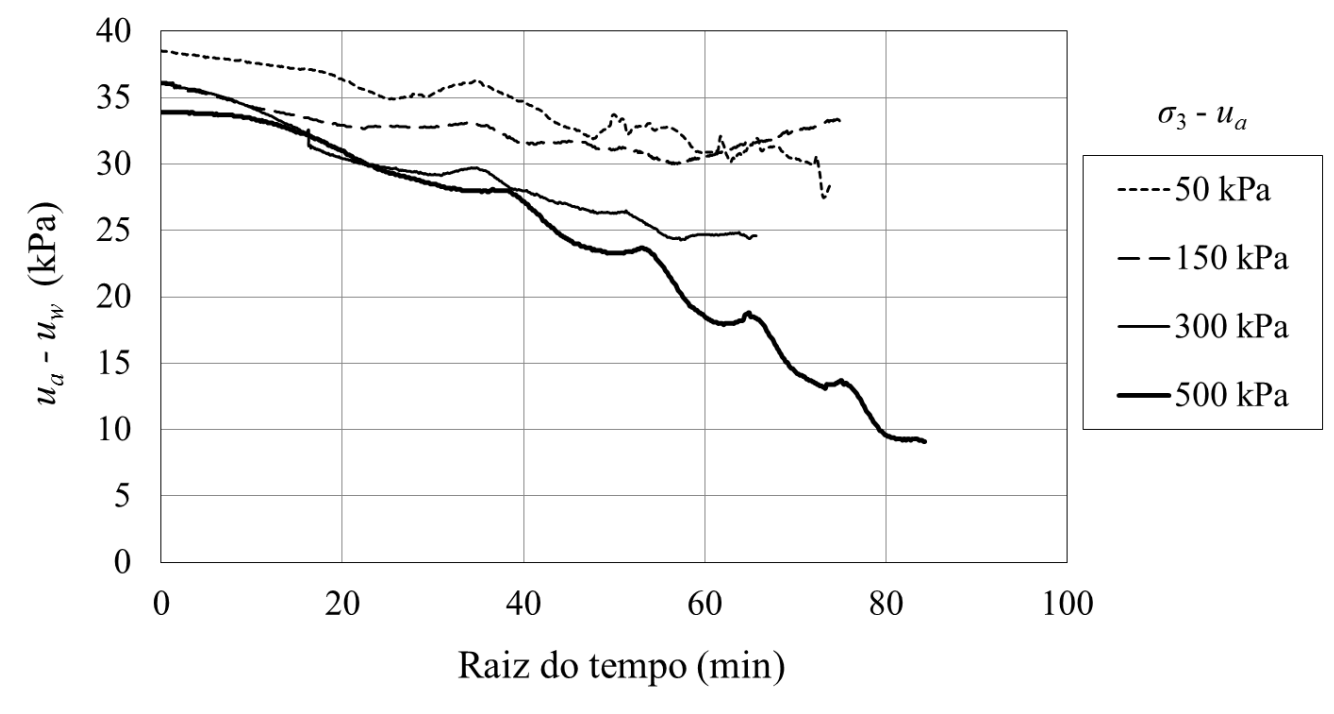

(a)

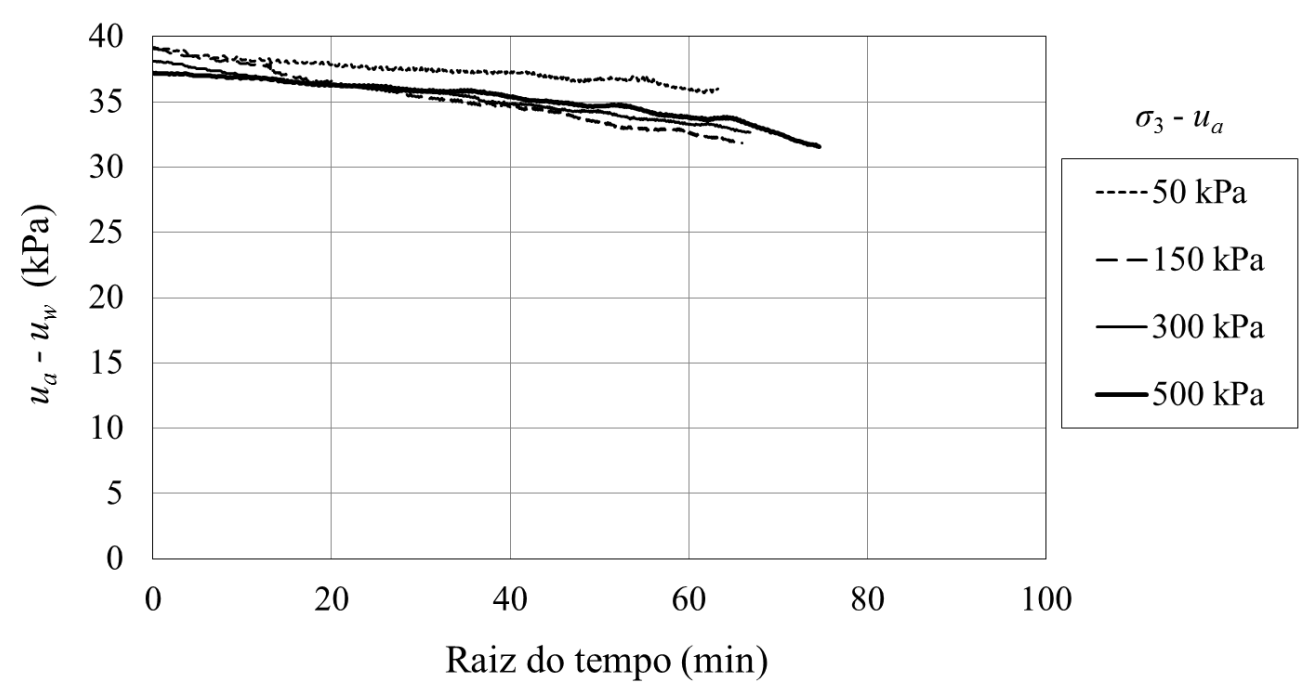

(b)

Figura 5.21. Estabilização da sucção no solo após adensamento do ensaio CW (a) com solo compactado e (b) indeformado com sucção imposta de $40 \mathrm{kPa}$.

O encruamento consiste no endurecimento do material, no caso o solo, pelo acréscimo de deformação plástica e introduz dificuldades na interpretação da resistência do solo porque, de modo simplificado, em cada tensão confinante tem-se um solo com características diferentes das do estágio anterior. Para ilustrar este fato, comparam-se os índices de vazios inicial e final do solo (após desmontagem do ensaio), que foram de 1,07 e 0,50, respectivamente, e apresentase a Figura 5.24, que mostra este corpo de prova depois do ensaio. Da figura, é possível notar que mesmo após $80 \%$ de redução de seu índice de vazios o corpo de prova não apresentou “embarrigamento", o que sugere que houve uma reorganização interna das partículas do solo com preenchimento dos macroporos do solo por partículas sólidas tornando-o mais denso e mais resistente em cada estágio. 

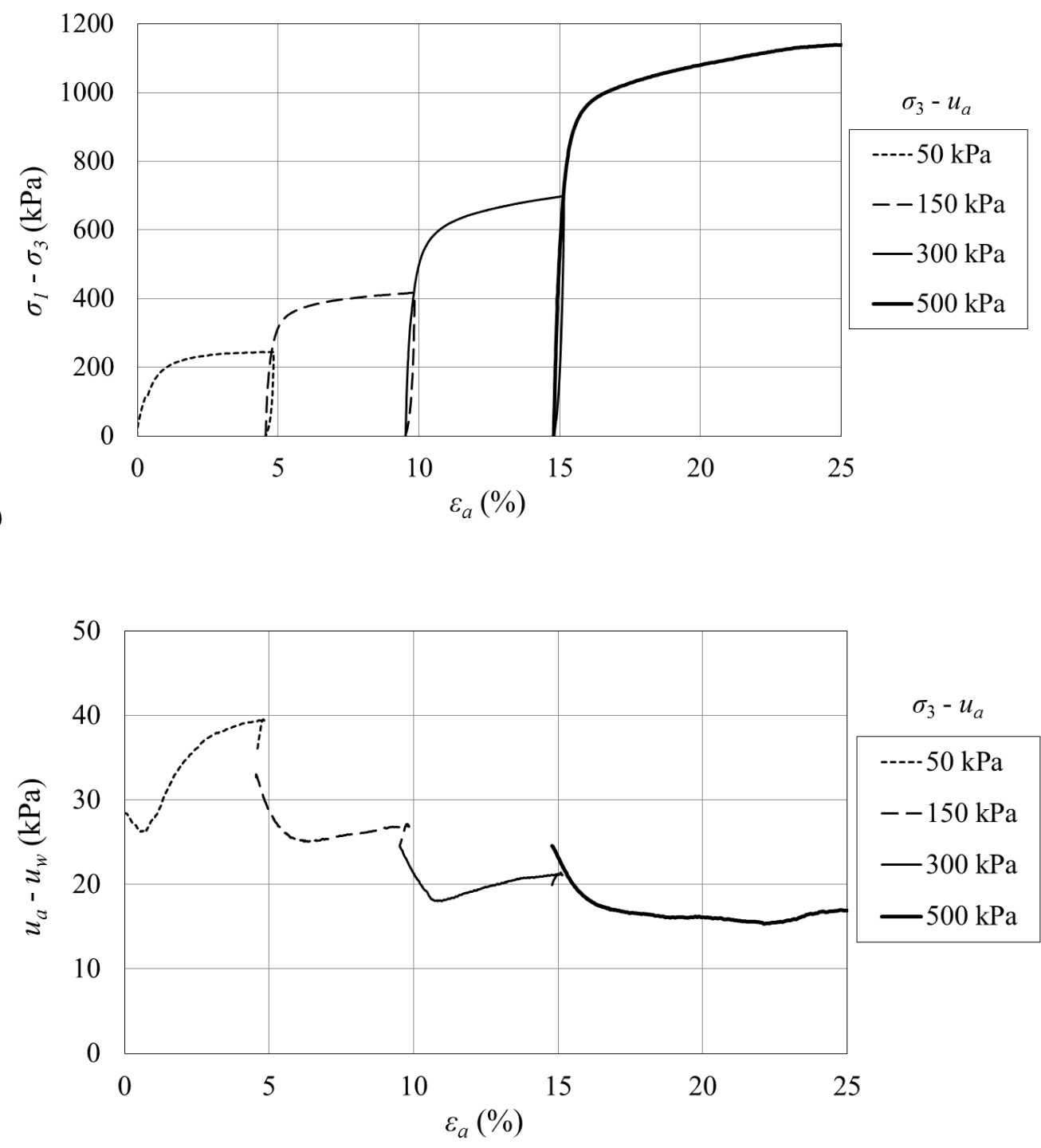

(b)

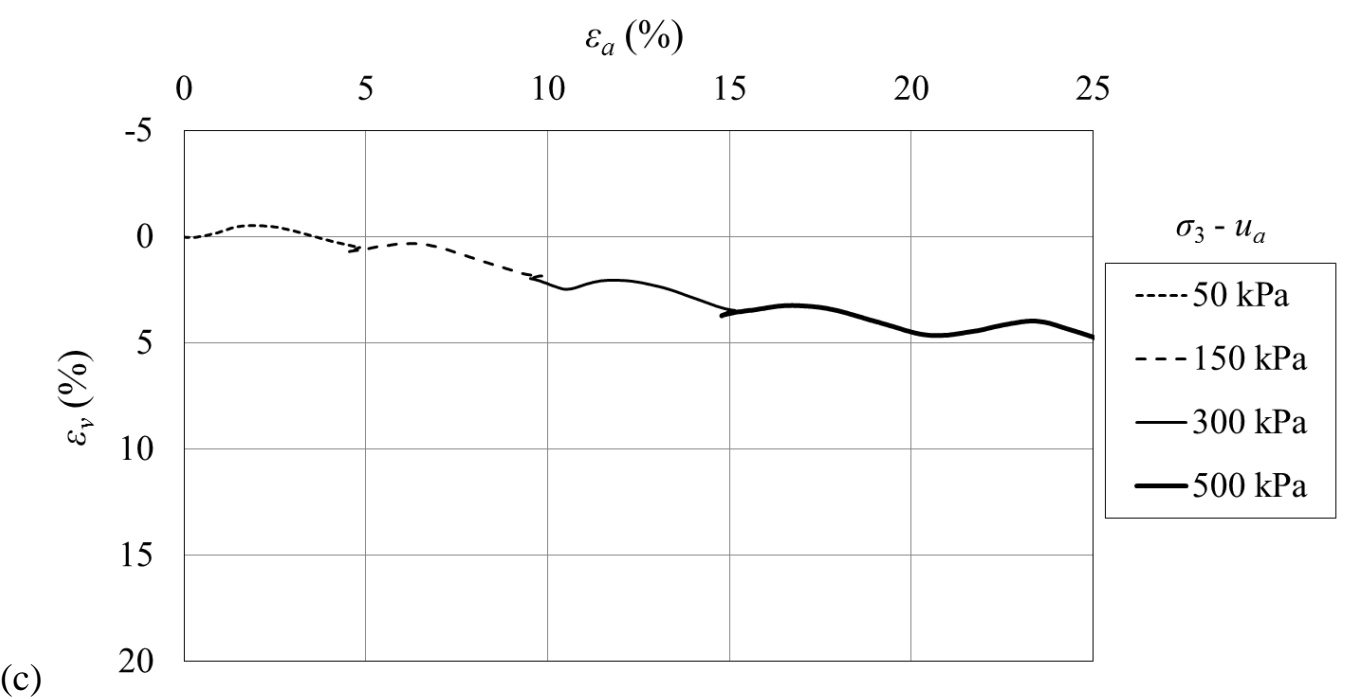

Figura 5.22. Curvas (a) tensão-deformação, (b) variação da sucção e (c) deformação volumétrica do ensaio CW com solo compactado e ensaiado com sucção inicial de $40 \mathrm{kPa}$. 


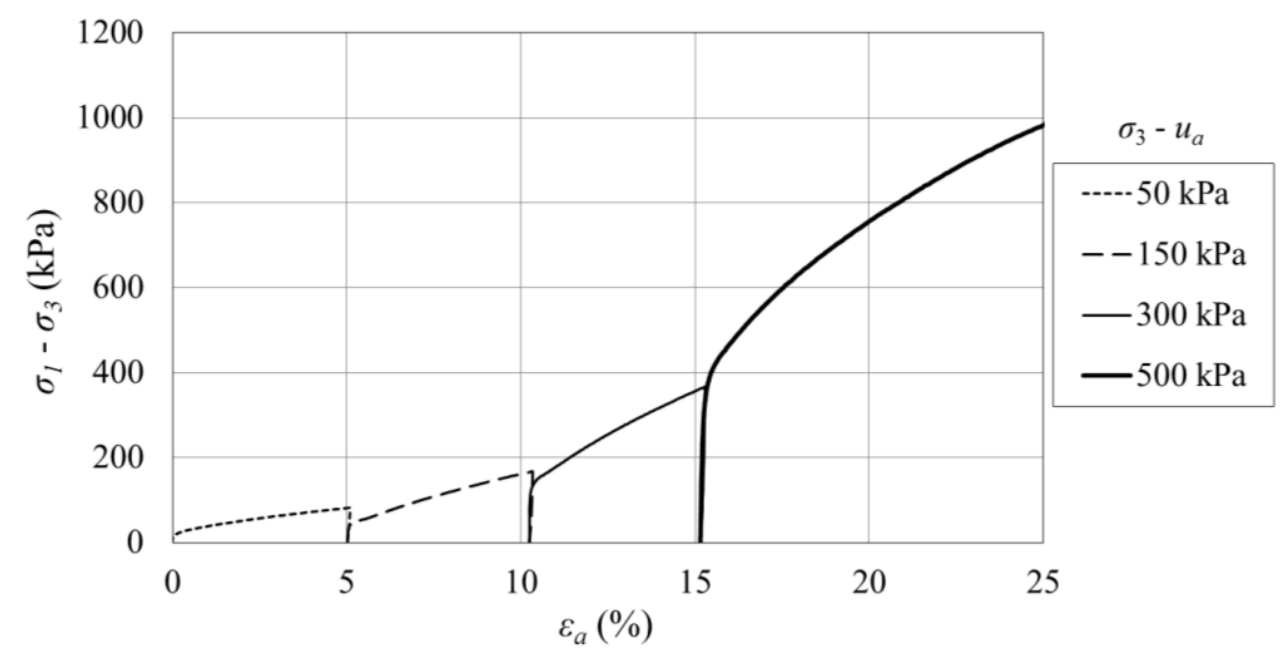

(a)

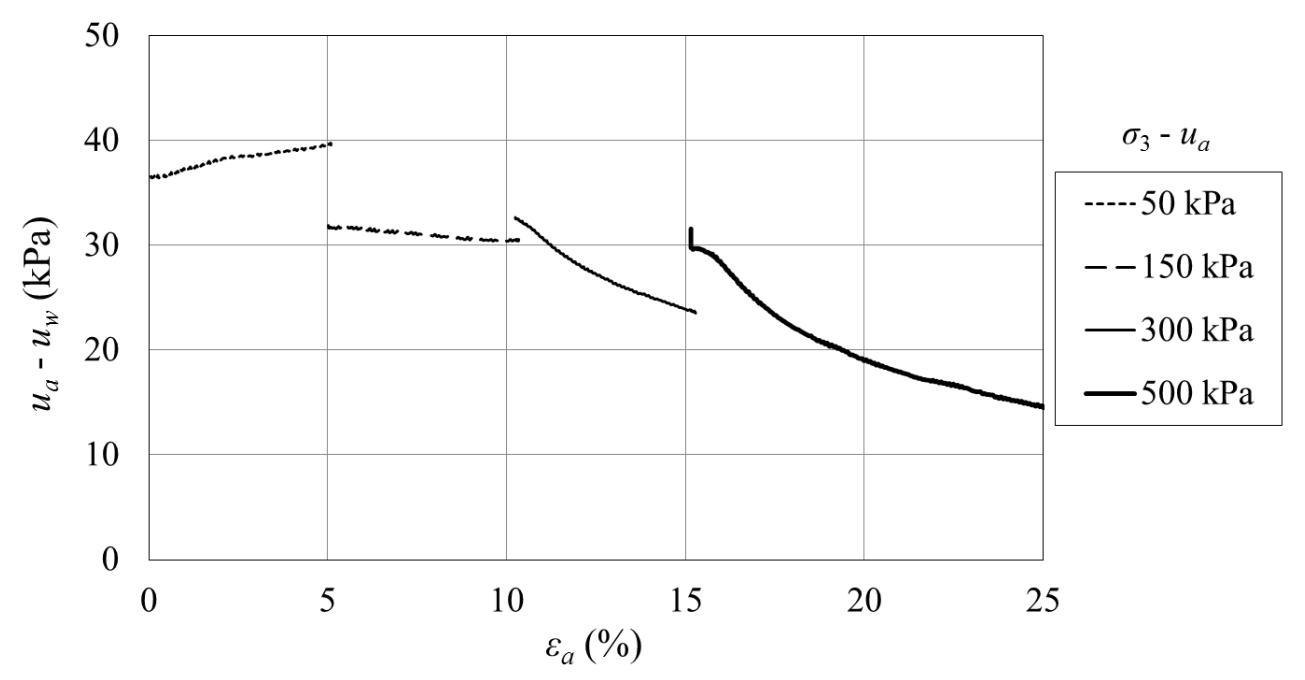

(b)

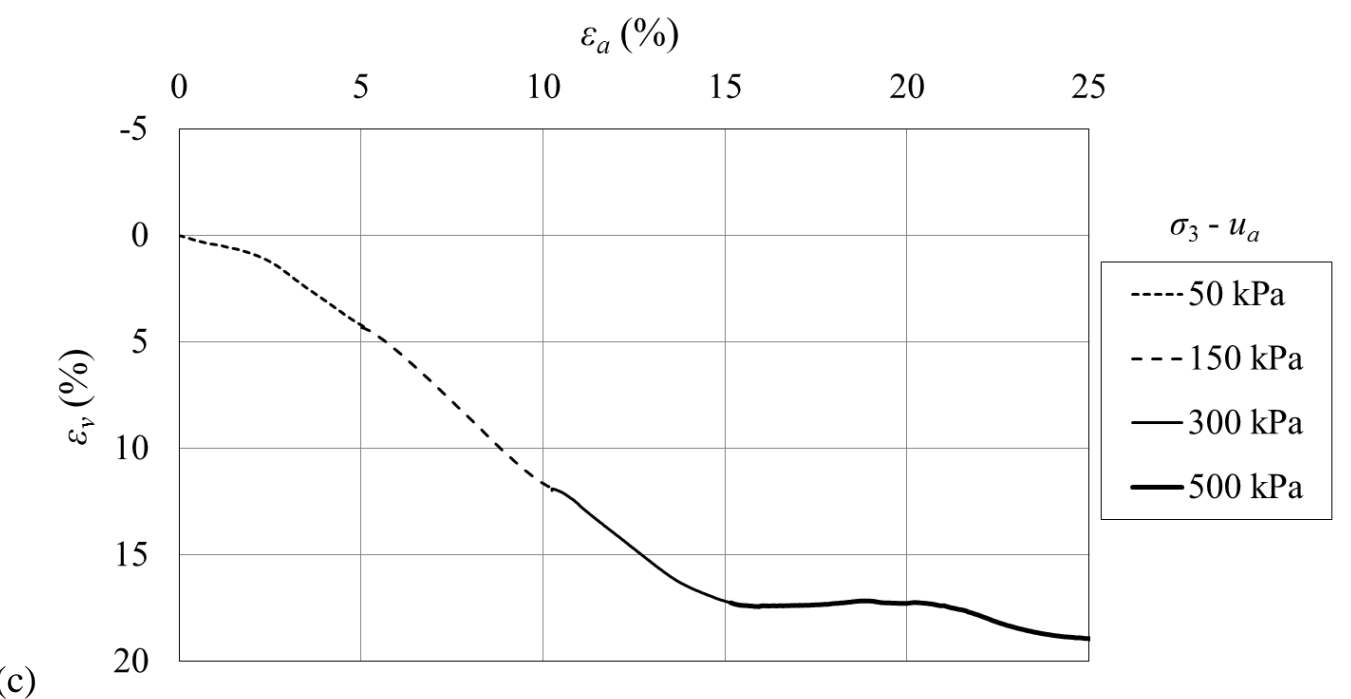

Figura 5.23. Curvas (a) tensão-deformação, (b) variação da sucção e (c) deformação volumétrica do ensaio CW com solo indeformado e ensaiado com sucção inicial de $40 \mathrm{kPa}$. 


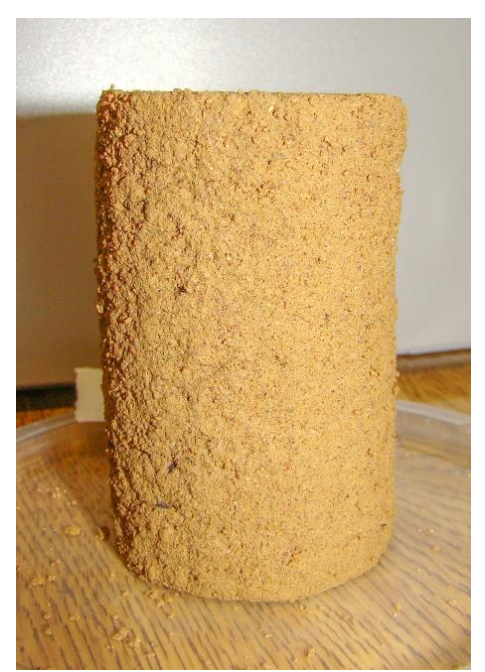

Figura 5.24. Corpo de prova de amostra indeformada após o ensaio CW com sucção inicial de $40 \mathrm{kPa}$.

Analisando a evolução da sucção com a deformação axial na Figura 5.22 (b), para as menores tensões confinantes a sucção aumentou durante a ruptura depois de um decréscimo inicial. Para as maiores tensões confinantes ocorreu redução da sucção com aumento das deformações. Este comportamento foi relatado também por Rahardjo et al. (2004), Oliveira (2004) e Georgetti (2010) para solos compactados, sendo que os primeiros ensaiaram solos de origem residual. A Figura 5.23 (b) mostra que o efeito da tensão confinante sobre a sucção do solo indeformado é semelhante ao relatado para o solo compactado, embora a variação da sucção tenda a ocorrer de maneira mais uniformes neste caso.

Já no que se refere à deformação volumétrica, a tendência geral que se observa nas Figuras 5.22 (c) e 5.23 (c) é de redução de volume do solo. Essa redução de volume total reflete a redução de volume de ar dos poros do solo, já que a quantidade de água permanece constante na fase de ruptura. Alguma dilatância pode ter ocorrido nos estágios de menor confinamento para o solo compactado, no entanto variações de temperatura no ambiente de ensaio podem ter afetado a precisão destas leituras, dificultando portanto uma avaliação mais precisa. Comparando o solo compactado e o indeformado, nota-se que o solo indeformado, com maior índice de vazios inicial, sofreu deformações volumétricas que foram cerca de quatro vezes os valores registrados para o solo compactado, o que corrobora a constatação de encruamento atrás referida. Pode-se ainda associar as curvas de deformações volumétricas às curvas desenvolvimento de sucção. À medida que o solo comprime $\left(\varepsilon_{v}>0\right)$, seu grau de saturação aumenta e portanto, a sucção diminui. Deste modo, nota-se boa concordância entre os gráficos (b) e (c) das Figuras 5.22 e 5.23.

Aos dados experimentais dos ensaios em solo saturado e não saturado foram ajustadas envoltórias planares de resistência ao cisalhamento para o solo compactado e indeformado. 
Estas envoltórias foram calculadas para a resistência máxima e seguem a proposta de Fredlund et al. (1978) apresentada na Eq. 2.8.

Para o solo compactado, mantendo-se a coesão e o ângulo de atrito efetivos obtidos pela envoltória saturada dos ensaios CD e CU (Figura 5.15), obteve-se ângulo $\phi^{b}$ de $27^{\circ}$ para a envoltória planar, com coeficiente de determinação de 0,99. A Figura 5.25 mostra esta envoltória no espaço $\left[\left(\sigma_{1}-\sigma_{3}\right) / 2\right],\left[\left(\sigma_{1}+\sigma_{3}\right) / 2-u_{a}\right]$ e $\left(u_{a}-u_{w}\right)$. Os parâmetros de resistência obtidos para o solo compactado mostram-se coerentes com os valores apresentados em Georgetti (2010), e ainda, $\phi^{b}$ está de acordo com os valores de referência apresentados por Fredlund e Rahardjo (1993).

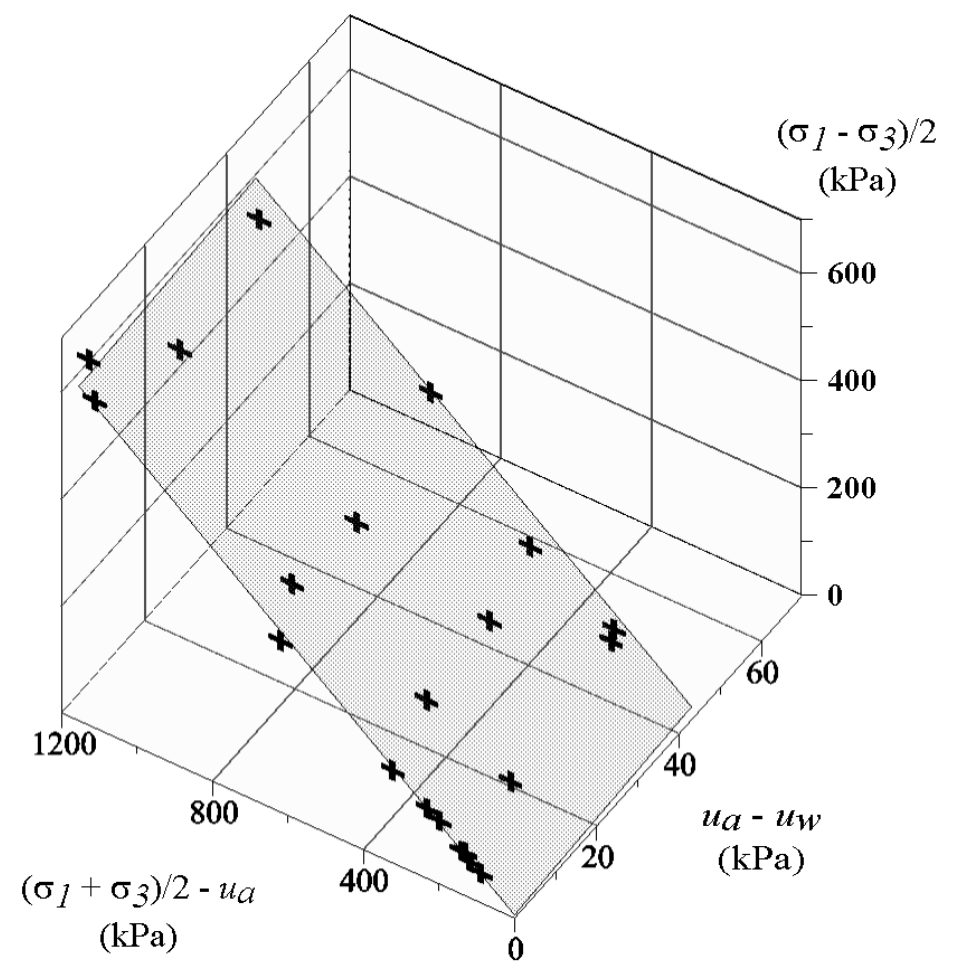

Figura 5.25. Envoltória planar de resistência ao cisalhamento para o solo compactado.

Para os resultados referentes ao solo indeformado, o ajuste de uma superfície planar aos dados de resistência máxima não se mostrou adequado. Com a realização de ensaios de múltiplos estágios e a ocorrência de encruamento do solo, não foi possível atingir sua resistência máxima em todos os estágios de cisalhamento, o que prejudicou a análise da envoltória de resistência. A Figura 5.26 exemplifica o posicionamento dos círculos de Mohr dos corpos de prova indeformados para a resistência máxima obtida em cada estágio com relação à envoltória de resistência do solo saturado. Esta figura apresenta os resultados para a tensão confinante líquida de $50 \mathrm{kPa}$ e sucções iniciais de 15, 40 e $80 \mathrm{kPa}$. As sucções referidas na figura são as 
correspondentes aos pontos de resistência máxima, ou seja, a sucção na ruptura. Nota-se que estes círculos estão abaixo da envoltória, enquanto espera-se que o solo com sucção adquira maior resistência e, na situação de ruptura, ultrapasse a envoltória de resistência do solo saturado. Isto confirma que ao final dos estágios de cisalhamento os corpos de prova não haviam alcançado a ruptura, justificando a inadequação de uma envoltória que compreenda os ensaios $\mathrm{CD}$ e $\mathrm{CW}$ com a amostra indeformada de solo.

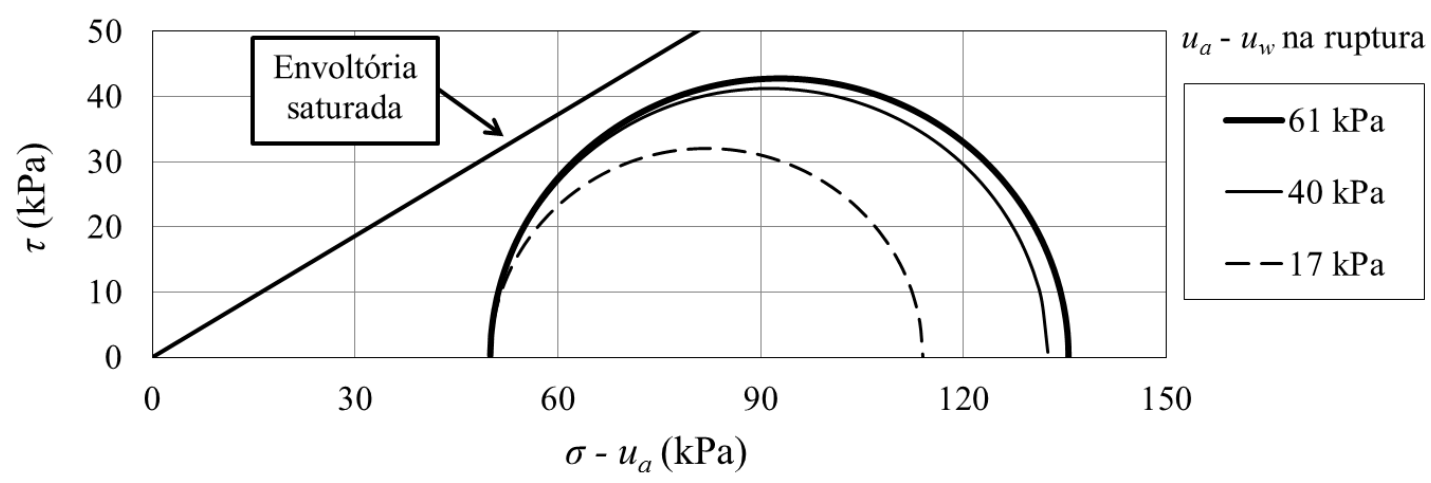

Figura 5.26. Círculos de Mohr dos corpos de prova indeformados em ensaios CW com tensão confinante líquida de $50 \mathrm{kPa}$.

No entanto, considerando-se os limites de aproximadamente $5 \%$ de deformação nos estágios intermediários dos ensaios $\mathrm{CW}$, uma envoltória planar de resistência tomando $5 \%$ de deformação axial como critério de ruptura para ensaios CD e CW fornece c' nulo, $\phi^{\prime}$ de $22^{\circ}$ e $\phi^{b}$ de $14^{\circ}$, com $r^{2}$ de 0,99. A Figura 5.27 ilustra esta envoltória. Embora este ângulo de atrito efetivo mostre-se menor do que o obtido para a resistência máxima do solo indeformado saturado, que foi de $32^{\circ}$, a envoltória para deformação de $5 \%$ indica coerência entre os resultados dos ensaios de resistência ao cisalhamento do solo indeformado.

\subsection{ENSAIOS DE DEFORMABILIDADE}

\subsubsection{Módulo de cisalhamento máximo do solo saturado}

A determinação do módulo de cisalhamento máximo $\left(G_{m a ́ x}\right)$ do solo saturado foi feita exclusivamente por meio de ensaios com bender elements. Esta série de ensaios utilizou corpos de prova compactados com massa específica seca média de $1,70 \mathrm{~g} / \mathrm{cm}^{3}$ e teores de umidade variando entre 11,2 e $17,1 \%$. Os índices físicos destes corpos de prova são apresentados na Tabela 5.5. 


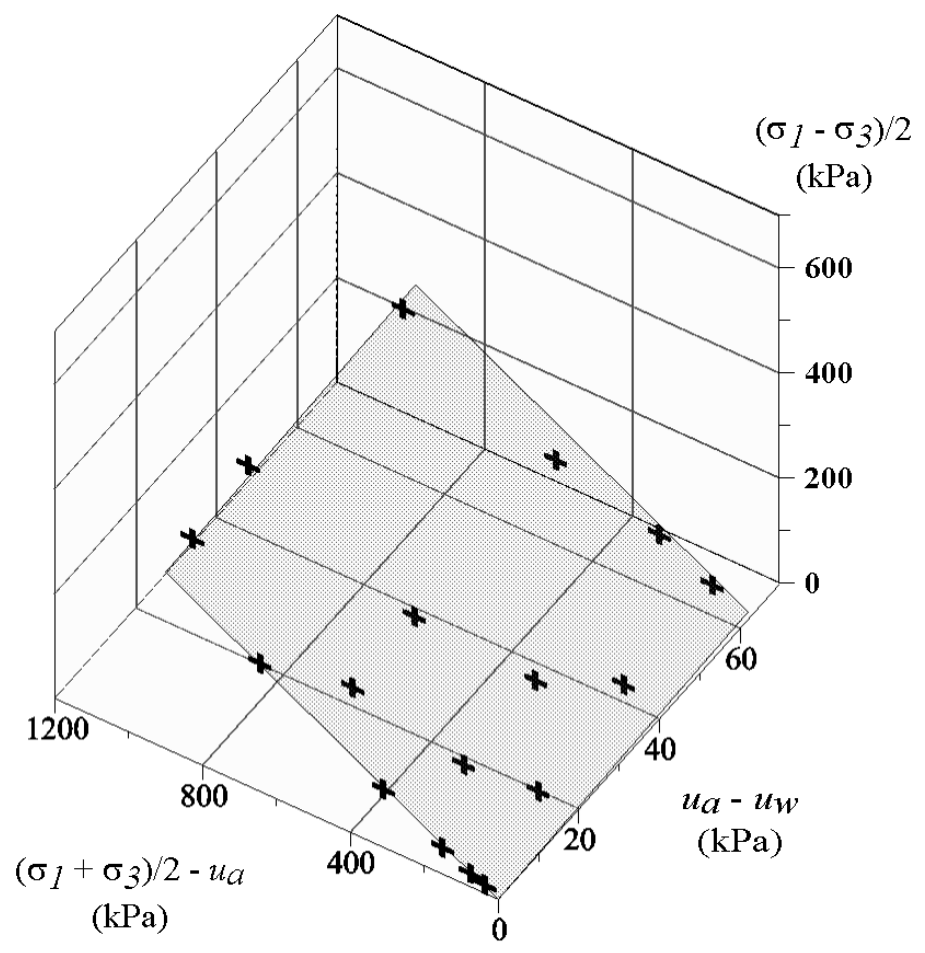

Figura 5.27. Envoltória planar de resistência ao cisalhamento para o solo indeformado.

Tabela 5.5. Índices físicos de moldagem dos corpos de prova compactados para ensaio com bender elements em condição saturada.

\begin{tabular}{cccc}
\hline \hline$w(\%)$ & $\rho_{d}\left(\mathrm{~g} / \mathrm{cm}^{3}\right)$ & $S_{r}(\%)$ & $e$ \\
\hline 11,2 & 1,698 & 53,6 & 0,554 \\
12,7 & 1,706 & 61,4 & 0,548 \\
13,9 & 1,700 & 66,3 & 0,553 \\
14,4 & 1,707 & 69,6 & 0,546 \\
17,1 & 1,709 & 82,7 & 0,545 \\
\hline \hline
\end{tabular}

Algumas respostas típicas dos sinais senoidais emitidos pelos bender elements são apresentados na Figura 5.28. Nesta figura mostram-se os sinais emitidos com frequência de 10 $\mathrm{kHz}$ e os respectivos sinais recebidos, que foram sempre empilhados 5 vezes. O empilhamento dos sinais de onda é prática corriqueira nos ensaios geofísicos e visa diminuir o efeito de ruídos aleatórios. Testes preliminares com bender elements indicaram que não ocorre melhora significativa nos sinais recebidos para empilhamento maior do que 5 vezes.

Os dados apresentados na Figura 5.28 correspondem aos corpos de prova compactados com teores de umidade de $11,2 \%$ e $17,1 \%$, ensaiados em condição saturada e submetidos a diferentes tensões confinantes líquidas $\left(\sigma_{3}-u_{w}\right)$ na primeira trajetória de confinamento. Considerando o método de determinação do tempo de percurso da onda mostrado na Figura 
4.10 e analisando a Figura 5.28, nota-se que para uma mesma tensão de confinamento, o corpo de prova compactado com $w=11,2 \%$ sempre apresenta menor tempo de percurso $(t)$ da onda em relação ao corpo de prova compactado com $w=17,1 \%$. Isso indica sua menor deformabilidade, já que $G_{m a ́ x}$ é inversamente proporcional ao quadrado de $t$ (Eq. 2.5). Além disso, é possível notar nesta figura a maior influência de $\sigma_{3}-u_{w}$ sobre o tempo de percurso do corpo de prova mais deformável $(w=17,1 \%)$.

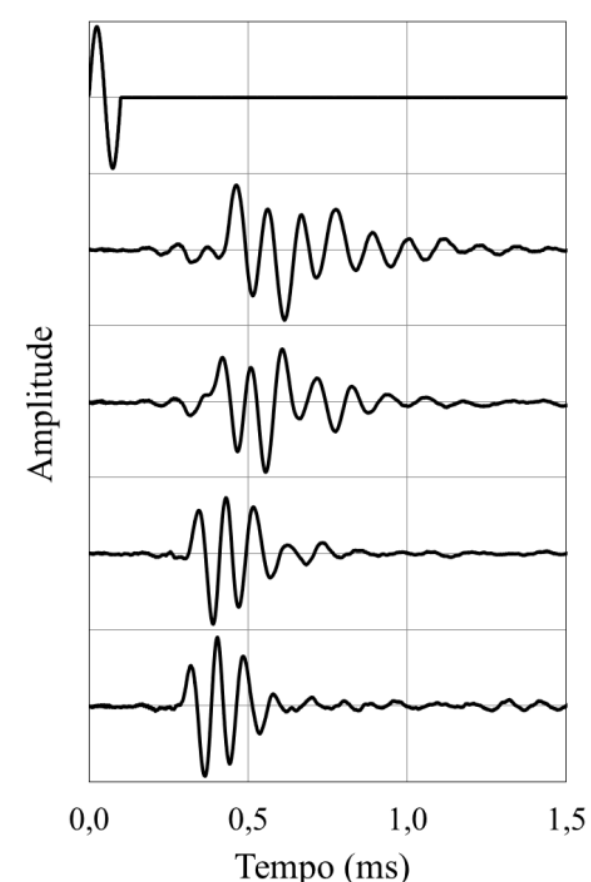

(a)

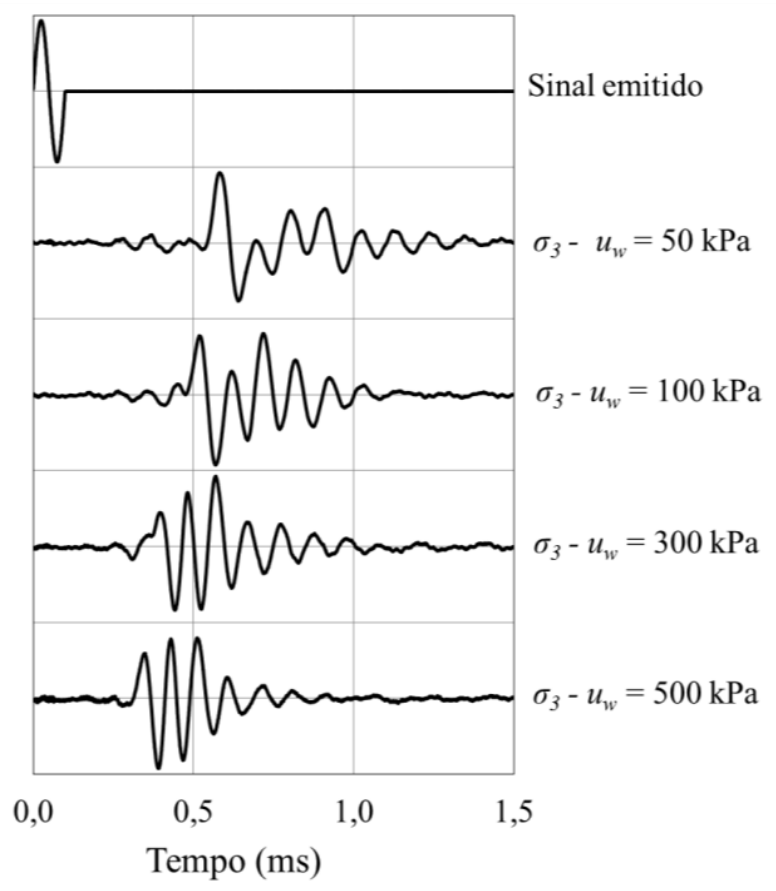

Figura 5.28. Respostas típicas dos ensaios com bender elements em solo compactado saturado para os teores de umidade de compactação de (a) 11,2\% e (b) 17,1\%.

A relação entre a distância percorrida pela onda de cisalhamento e o comprimento da onda $\left(L_{t} / \lambda\right)$ foi utilizada na avaliação da influência de interferências nos sinais recebidos, de acordo com sugestões de Sanchez-Salinero et al. (1986), Jovičić et al. (1996) e Leong et al. (2005). A distância percorrida foi tomada como a distância entre extremidades dos bender elements, enquanto o comprimento da onda recebida foi estimado a partir da frequência da onda emitida $\left(f_{\text {emitida }}\right)$ e da velocidade da onda de cisalhamento $\left(V_{s}\right)$

$$
\lambda=V_{s} / f_{\text {emitida }}
$$

A Figura 5.29 apresenta velocidades de ondas de cisalhamento para corpos de prova compactados com teores de umidade de $11,2 \%$ e $17,1 \%$ ensaiados em condição saturada. 
Somente dados da primeira trajetória de confinamento são mostradas nestes gráficos. Verificase prontamente nesta figura o efeito de $\sigma_{3}-u_{w}$ em aumentar a velocidade da onda de cisalhamento no solo. As magnitudes de velocidades obtidas nessa pesquisa para o solo compactado saturado são comparáveis aos resultados experimentais de ensaios com bender elements apresentados por Youn et al. (2008) e um pouco superiores aos obtidos por Brignoli et al. (1996) para areias saturadas.

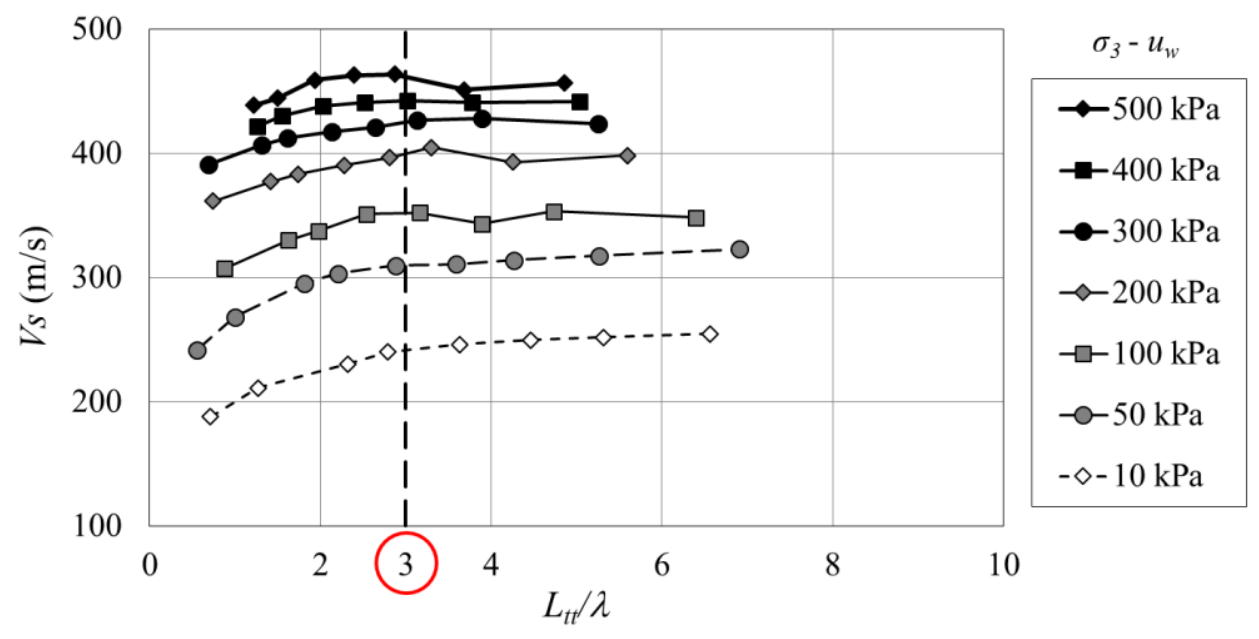

(a)

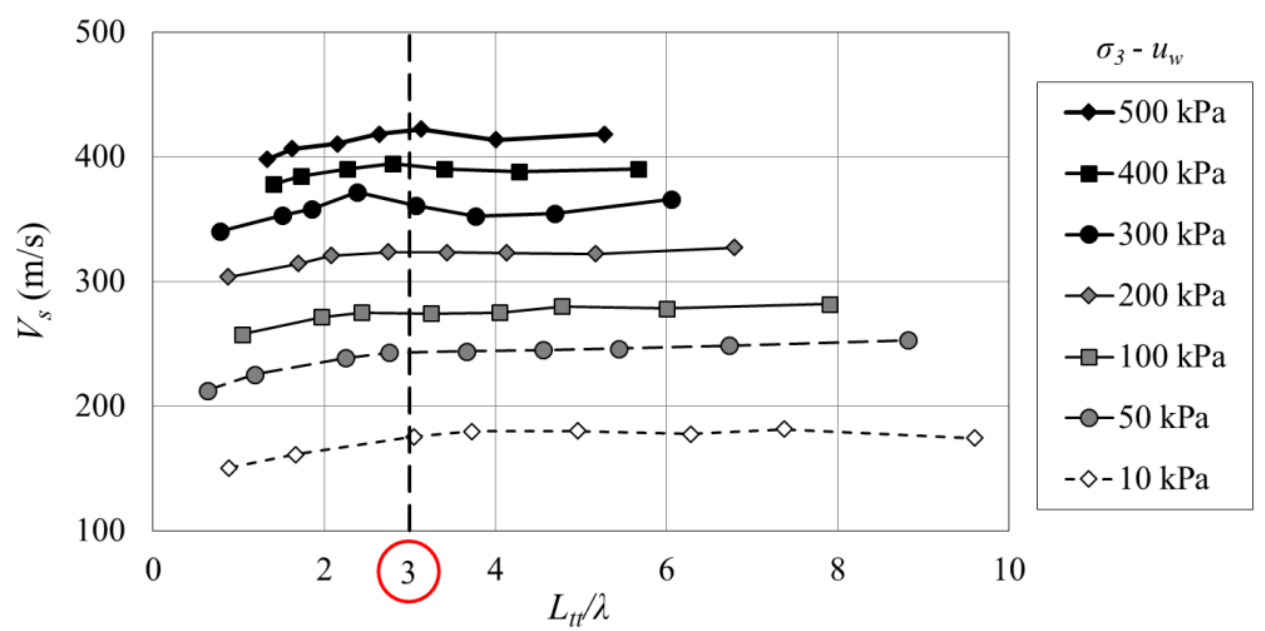

Figura 5.29. Velocidade da onda de cisalhamento dos ensaios com bender elements para solo compactado com teores de umidade de (a) 11,2\% e (b) 17,1\% e ensaiados em condição saturada.

Embora não se observe na Figura 5.29 uma mudança marcante de comportamento das curvas com o aumento de $L_{t} / \lambda$, a análise geral de todos os ensaios com bender elements realizados nesta pesquisa indicou que, quando seu valor é inferior a 3,0 as curvas apontam para aumento da velocidade da onda, e depois disso, os valores de $V_{s}$ tendem a se estabilizar. Tal comportamento se mostra mais pronunciado quanto menor é a tensão de confinamento. Esta 
análise sugere que o efeito de interferências nos sinais é reduzido para $L_{t t} / \lambda$ maiores que 3,0. Com base nestas evidências e em recomendações da literatura (Leong et al., 2005 por exemplo), para uma dada tensão confinante em um determinado corpo de prova, $V_{s}$ foi tomado como a média dos valores para $L_{t t} / \lambda$ igual ou maior a 3,0. Este critério se estendeu aos demais ensaios com bender elements.

Dos resultados dos ensaios com solo saturado podem ser obtidas curvas que mostram a variação de $G_{m a ́ x}$ com a tensão de confinamento e o índice de vazios do solo (Figuras 5.30 e 5.31). Na Figura 5.30 observa-se o aumento de $G_{m a ́ x}$ com o aumento de $\sigma_{3}-u_{w}$ de 10 para até $500 \mathrm{kPa}$, que foi expresso por meio de funções potenciais

$$
G_{\text {máx }}=\beta_{1}\left(\sigma_{3}-u_{w}\right)^{\beta_{2}}
$$

onde $\beta_{1}$ e $\beta_{2}$ são parâmetros empíricos, que são apresentados na Tabela 5.6.

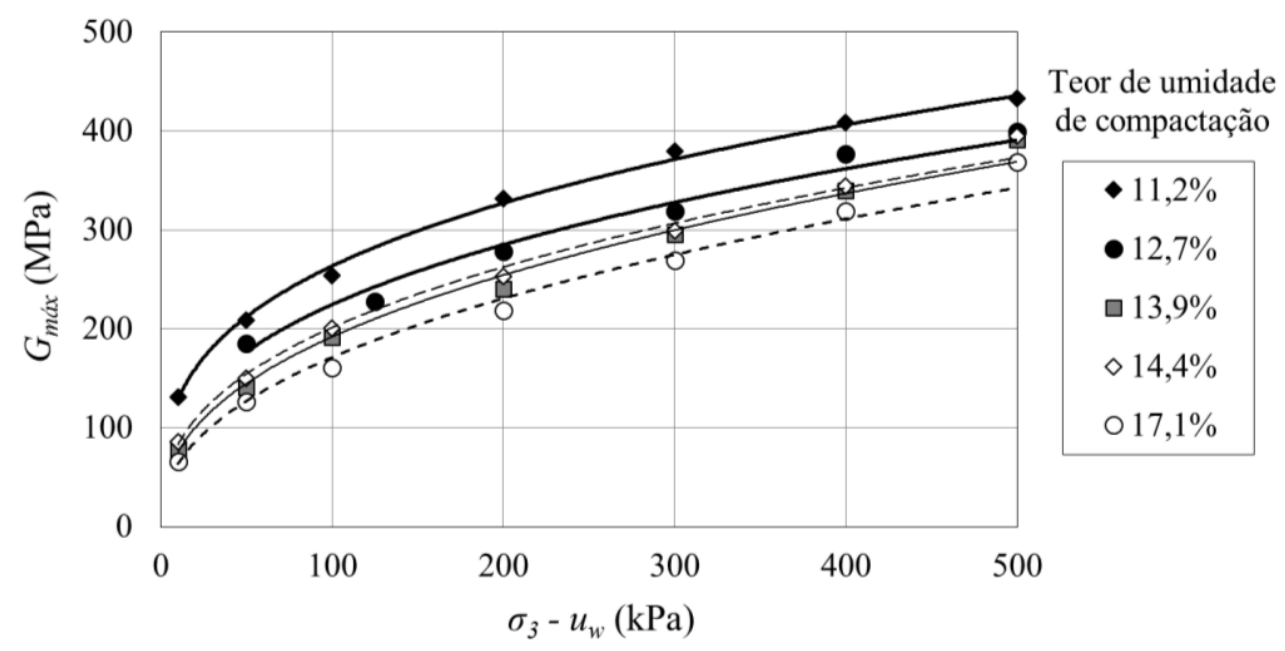

Figura 5.30. Variação do módulo de cisalhamento máximo com a tensão de confinamento para solo compactado em diferentes teores de umidade e ensaiado em condição saturada.

Os dados mostram ainda aumento de 230 a $460 \%$ em $G_{\text {máx }}$ neste intervalo de tensões, com menores variações para os corpos de prova com menores teores de umidade de compactação. Para uma mesma tensão confinante, os valores de módulo de cisalhamento máximo foram mais altos para os corpos de prova com menores teores de umidade de compactação, como seria de se esperar, já que a compactação do solo no ramo seco da curva de compactação é responsável por uma estrutura menos deformável do solo. 
Na Figura 5.31, para destacar a variação do índice de vazios do solo no decorrer dos ensaios, esta propriedade foi normalizada pelo seu valor na moldagem. $O$ índice de vazios médio na moldagem dos corpos de prova foi de 0,55 . As setas indicam a trajetória seguida durante os ensaios, de onde se nota que as maiores reduções nos índices de vazios aconteceram na trajetória de confinamento e nas maiores umidades de moldagem. Para o corpo de prova moldado com o maior teor de umidade, a redução do índice de vazios foi de cerca de $10 \%$ para um confinamento variando de zero a $500 \mathrm{kPa}$. Pode-se observar que no descarregamento o solo tende a aumentar pouco de volume e que, no recarregamento, as curvas seguem trajetória oposta.

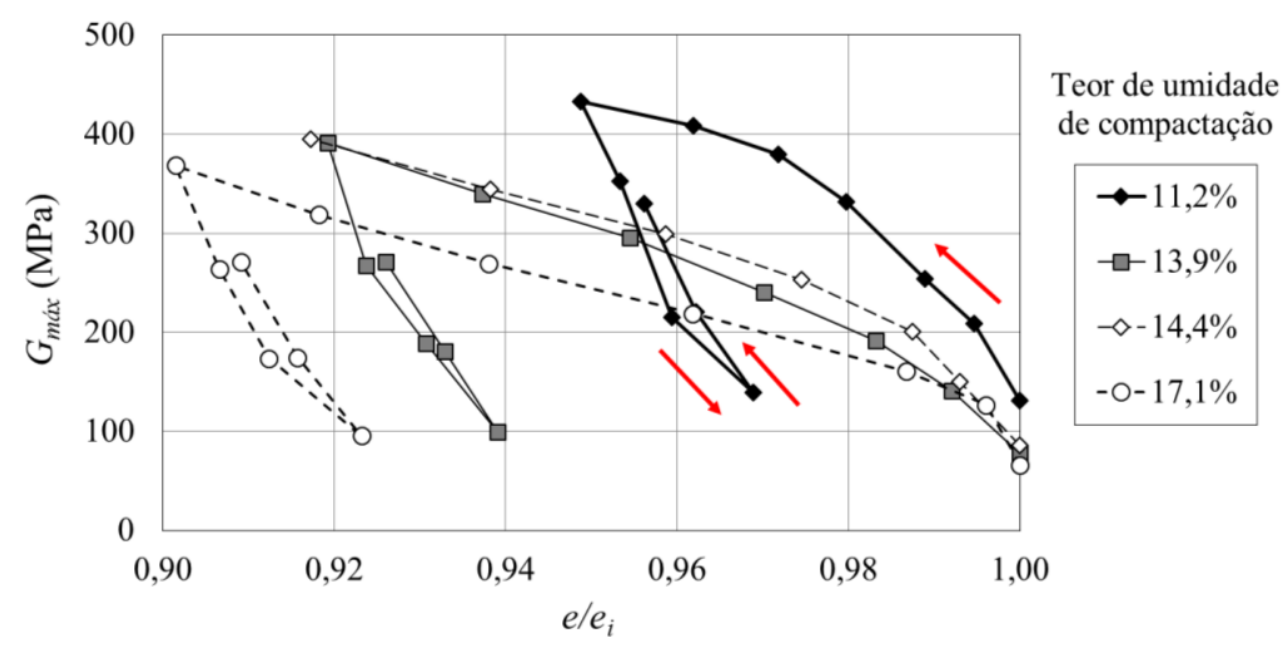

Figura 5.31. Variação do módulo de cisalhamento máximo com a relação entre índice de vazios e índice de vazios inicial para solo compactado em diferentes teores de umidade e ensaiado em condição saturada.

Tabela 5.6. Parâmetros dos ajustes de modelos potenciais para os ensaios com solo compactado saturado em ensaios com bender elements (Eq. 5.2).

\begin{tabular}{cccc}
\hline \hline$w$ na compactação & $\beta_{1}{ }^{*}$ & $\beta_{2}{ }^{*}$ & $r^{2}$ \\
\hline $11,2 \%$ & 62,5 & 0,312 & 0,99 \\
$12,7 \%$ & 46,0 & 0,344 & 0,98 \\
$13,9 \%$ & 29,7 & 0,406 & 0,99 \\
$14,4 \%$ & 34,4 & 0,383 & 0,99 \\
$17,1 \%$ & 23,5 & 0,431 & 0,99
\end{tabular}

* Parâmetros determinados para $G_{\text {máx }}$ em MPa e $\sigma_{3}-u_{w}$ em kPa.

A influência da trajetória de tensão sobre $G_{m a ́ x}$ é mostrada na Figura 5.32, onde se incluem resultados de dois dos ensaios realizados. Nota-se a ausência de um padrão de comportamento 
dos dados experimentais no que se refere à variação de $G_{\text {máx }}$ com o ciclo de desconfinamento e reconfinamento. Entretanto, em todos os casos as variações de $G_{m a ́ x}$ são inferiores a 15\%. Dadas às coerentes variações dos índices de vazios registradas no decorrer dos ensaios, uma possível causa da dispersão dos resultados no que se refere à trajetória de tensão é a determinação do tempo de percurso da onda no solo. Embora tenha-se buscado nesta pesquisa diminuir as incertezas com relação à determinação de $t$, este é um assunto ainda em discussão na literatura, sua relativa subjetividade tem sido reconhecida (Jovičić et al., 1996; Pennington et al., 2001; Chan, 2010).

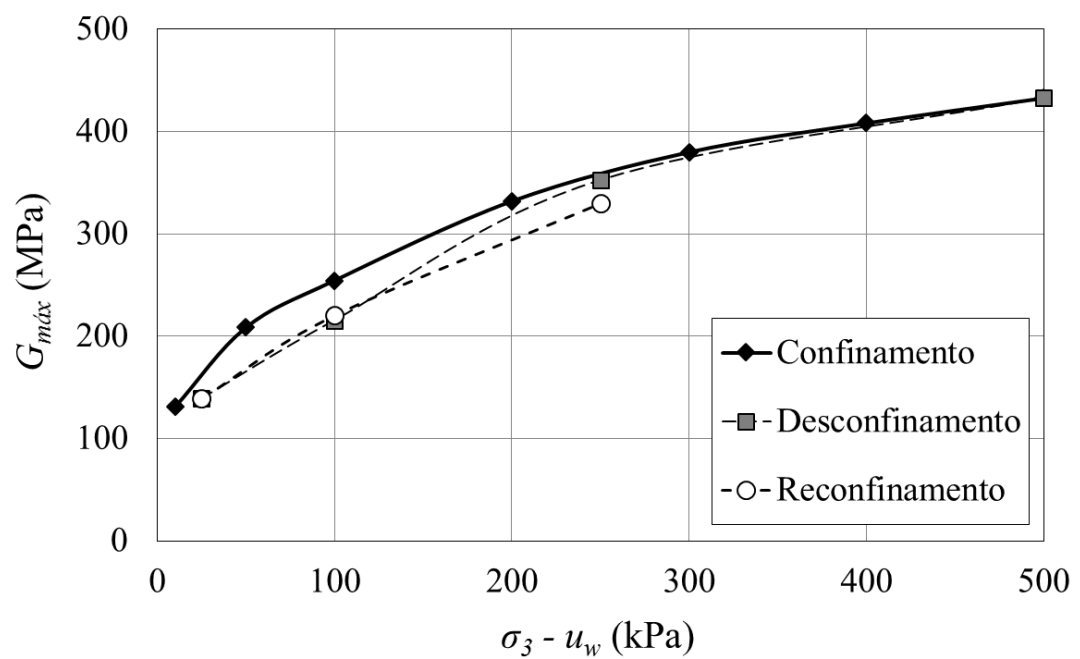

(a)

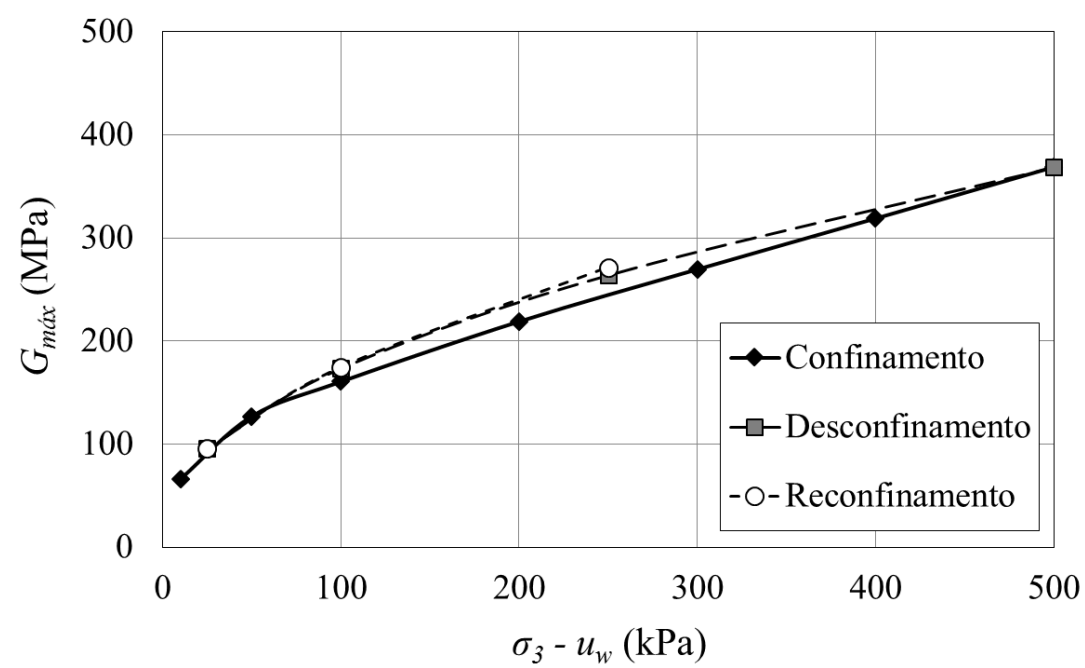

Figura 5.32. Variação do módulo de cisalhamento máximo com a trajetória de tensão para solo compactado com teores de umidade de (a) 11,2\% e (b) 17,1\% ensaiado em condição saturada. 


\subsubsection{Módulo de cisalhamento máximo do solo não saturado}

Dentre as técnicas de ensaio utilizadas nesta pesquisa, as de bender elements e coluna ressonante forneceram dados de módulo de cisalhamento máximo do solo não saturado. Nesta seção são apesentados os resultados dos ensaios com bender elements, os quais visaram especificamente a determinação de $G_{m a ́ x}$. Nesta série de ensaios com solo não saturado foram usados corpos de prova compactados com teores de umidade médios de $12,8 \%$ e 13,9\% e também moldados de amostra indeformada. As sucções de ensaio e os índices físicos de moldagem dos corpos de prova são mostrados na Tabela 5.7.

Tabela 5.7. Índices físicos de moldagem dos corpos de prova compactados para ensaio com bender elements em condição não saturada.

\begin{tabular}{cccccc}
\hline \hline Amostra & $u_{a}-u_{w}$ de ensaio $(\mathrm{kPa})$ & $w(\%)$ & $\rho_{d}\left(\mathrm{~g} / \mathrm{cm}^{3}\right)$ & $S_{r}(\%)$ & $e$ \\
\hline Compactada & 15 & 12,6 & 1,712 & 61,4 & 0,542 \\
$w_{\text {médio }}=12,8 \%$ & 40 & 12,9 & 1,709 & 62,0 & 0,550 \\
\hline & 15 & 13,6 & 1,707 & 65,8 & 0,547 \\
Compactada & 40 & 14,0 & 1,708 & 67,8 & 0,546 \\
$w_{\text {médio }}=13,9 \%$ & 100 & 13,9 & 1,708 & 67,3 & 0,545 \\
& 15 & 11,4 & 1,294 & 28,9 & 1,048 \\
Indeformada & 30 & 11,2 & 1,297 & 28,3 & 1,043 \\
\hline \hline
\end{tabular}

Para fins comparativos, juntamente com os dados do solo não saturado são mostrados dados do solo saturado já apresentados na seção anterior. O solo saturado é referido como sucção $\left(u_{a}-u_{w}\right)$ igual a $0 \mathrm{kPa}$.

Respostas típicas do solo captadas pelos bender elements são mostradas na Figura 5.33. Esta figura apresenta resultados para o solo compactado na umidade de $13,9 \%$, sendo que em (a) são mostrados os sinais recebidos para sinais emitidos na frequência de $12,5 \mathrm{kHz}$ quando a tensão confinante líquida foi de $100 \mathrm{kPa}$, e em (b) são mostrados os sinais para frequência de $16,7 \mathrm{kHz}$ e tensão confinante líquida de $500 \mathrm{kPa}$. Em ambos os casos observa-se que o tempo de percurso da onda significativamente diminuiu quando se compara o solo saturado com o não saturado. Na Figura 5.33 (a) por exemplo, $t$ é de $0,45 \mathrm{~ms}$ para o solo saturado e 0,26 ms para o solo com $15 \mathrm{kPa}$ de sucção, uma redução de $42 \%$. De acordo com a curva de retenção de água deste solo (Figura 5.2 b), quando o solo sai da saturação em direção à sucção de $15 \mathrm{kPa}$, quase $40 \%$ da água intersticial é drenada do solo, o que representa um grande decréscimo de deformabilidade e portanto, uma redução no tempo de percurso da onda de cisalhamento. 


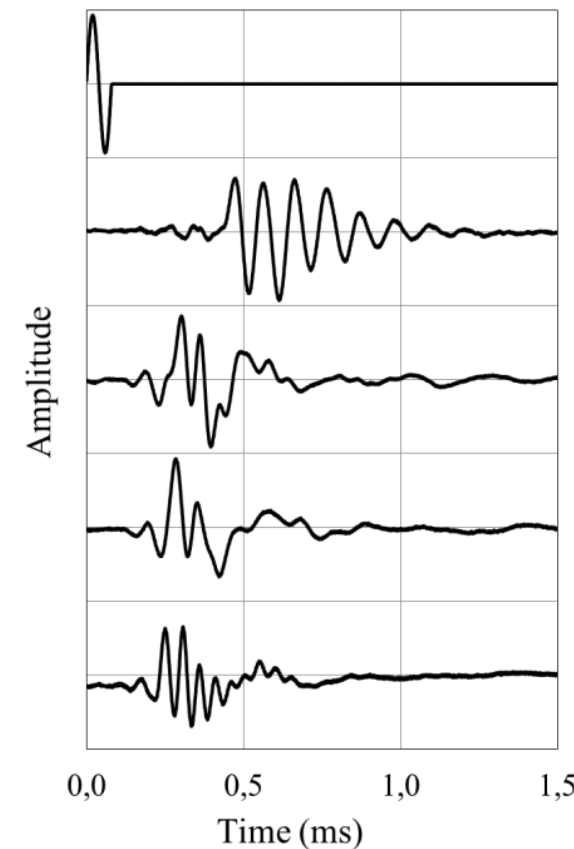

(a)

Figura 5.33. Respostas típicas dos ensaios com bender elements em solo compactado com 13,9\% de umidade para as tensões confinantes líquidas de (a) 100 e (b) $500 \mathrm{kPa}$.

A Figura 5.34 exemplifica a resposta do solo não saturado frente a diferentes frequências de excitação dos bender elements por meio da variação da velocidade das ondas de cisalhamento com a relação entre distância percorrida e comprimento da onda. Estes dados são da trajetória de confinamento para o solo compactado com teor de umidade de 13,9\% e solo indeformado, ambos com sucção de $15 \mathrm{kPa}$. Os corpos de prova indeformados foram submetidos a uma faixa menor de tensão de confinamento e sucção, tendo em vista valores mais usuais de campo. É possível observar nesta figura que, para uma mesma tensão confinante líquida $\left(\sigma_{3}-u_{a}\right)$ o solo compactado apresenta maiores velocidades e, portanto, menor deformabilidade, indicando a melhora nesta propriedade mecânica com a dendificação do solo. Além disso, os dados na Figura 5.34 confirmam a tendência observada na Figura 5.29 de velocidades crescentes para baixos $L_{t t} / \lambda$ e tendência à um valor constante com seu aumento.

A Figura 5.35 apresenta a variação de $V_{s}$ com a tensão confinante para todos os corpos de prova. Nota-se que em todos os casos o solo exibe a mesma tendência de aumento da velocidade de cisalhamento com o confinamento, embora a taxa de aumento da velocidade tenda a diminuir para as maiores tensões confinantes. Este efeito de redução na taxa de aumento de $V_{s}$ foi mais pronunciado para o solo compactado. Pode-se observar ainda nas Figuras 5.35 (a) e (b) que a sucção também exerce sua influência no aumento de $V_{s}$. A divergência dos resultados para as sucções de 15 e $40 \mathrm{kPa}$ em (a) está possivelmente associada ao menor teor de umidade de compactação do corpo de prova ensaiado com $15 \mathrm{kPa}$ de sucção. Já quando se trata do solo 
indeformado, o aumento da sucção de 15 para $30 \mathrm{kPa}$ não interferiu na velocidade da onda de cisalhamento (Figura 5.35 c), o que pode ser associado ao comportamento da curva de retenção de água desta amostra, que apresenta um trecho praticamente horizontal entre tais sucções.

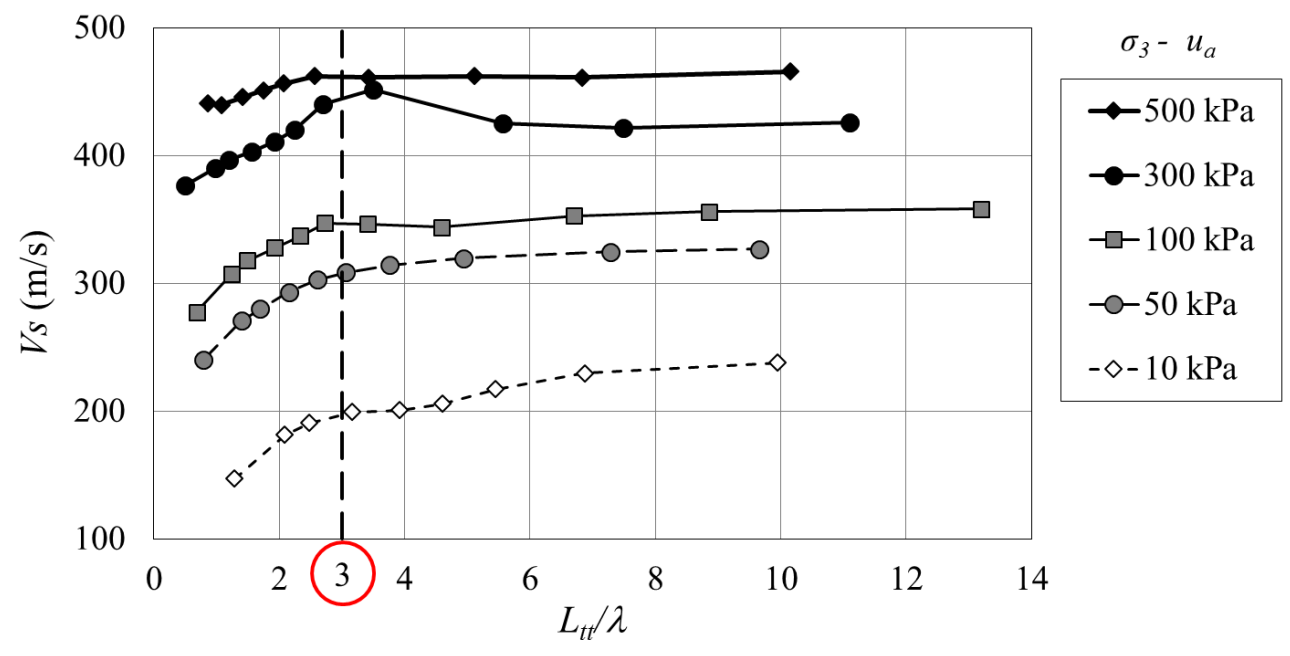

(a)

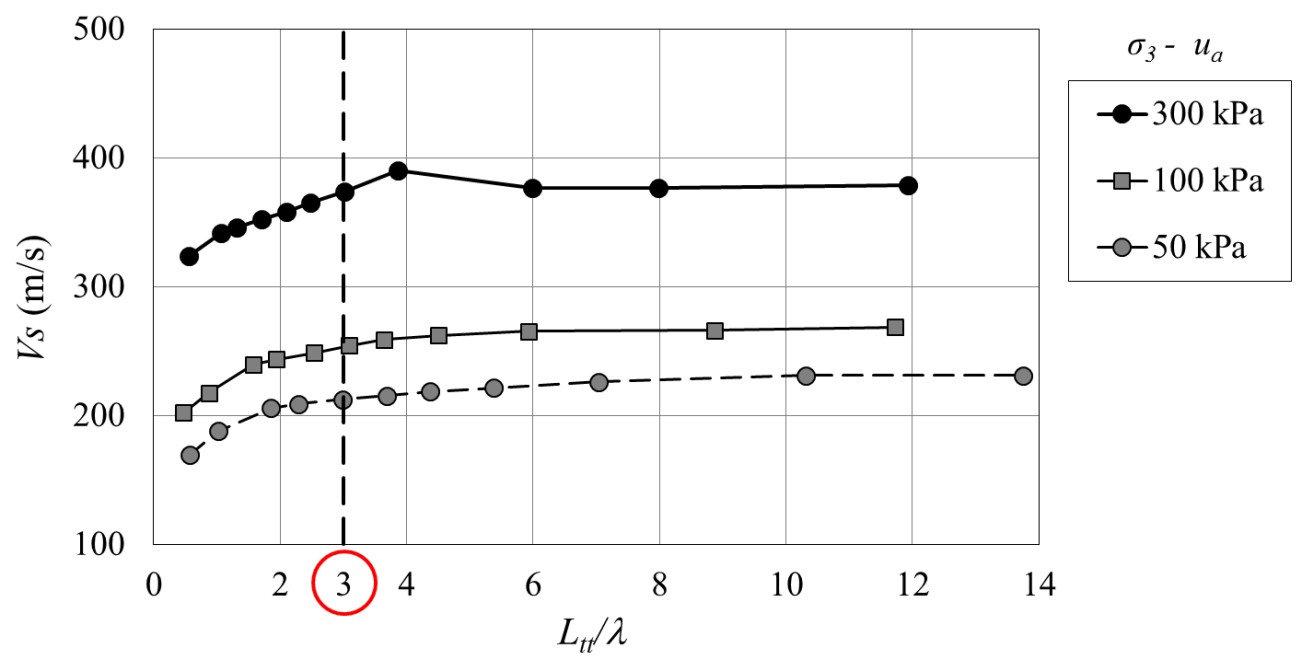

Figura 5.34. Velocidade da onda de cisalhamento dos ensaios com bender elements para (a) solo compactado com 13,9\% e (b) solo indeformado, na sucção de $15 \mathrm{kPa}$.

Considerando o módulo de cisalhamento máximo, a Figura 5.36 mostra sua dependência com relação à tensão confinante e à sucção do solo. Para o solo compactado da Figura 5.36 (b), por exemplo, $G_{m a ́ x}$ variou de 78 a $466 \mathrm{MPa}$. Quando o solo foi ensaiado em condição indeformada, $G_{\text {máx }}$ variou de 47 até $234 \mathrm{MPa}$, uma faixa de valores que é semelhante à apresentada por Barros (1997) para amostras indeformadas coletadas em São Carlos. 


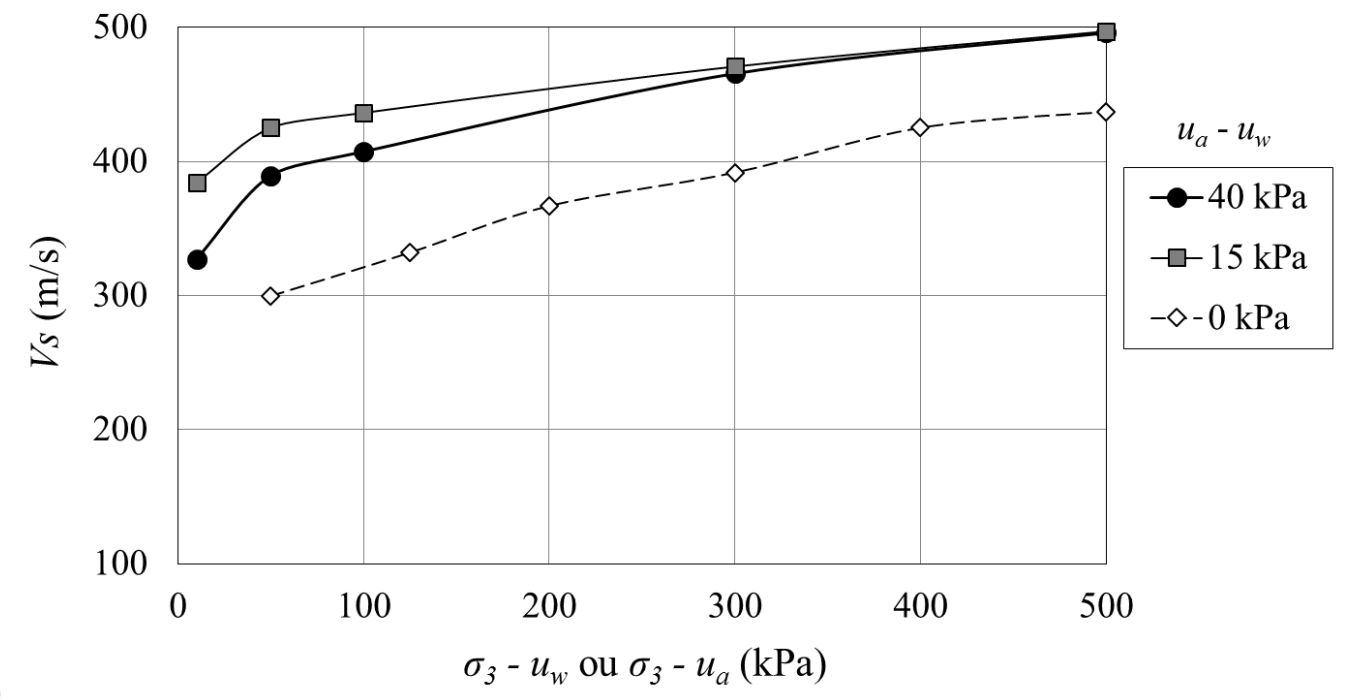

(a)

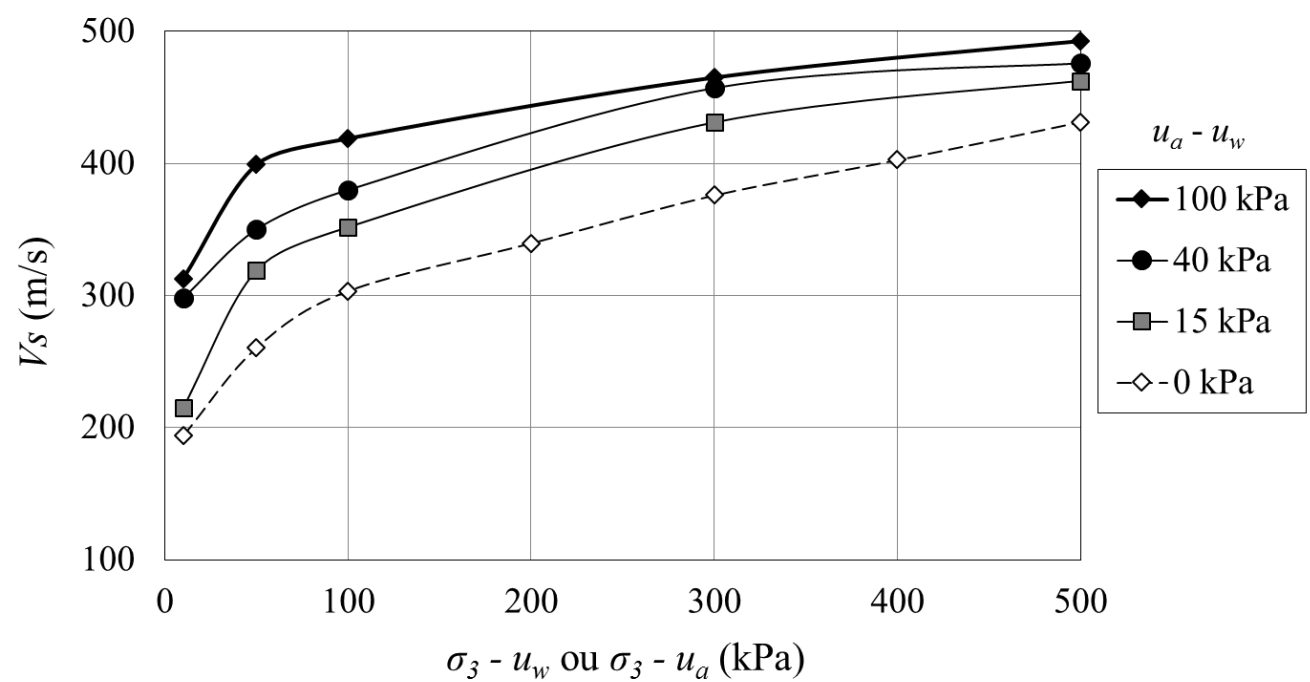

(b)

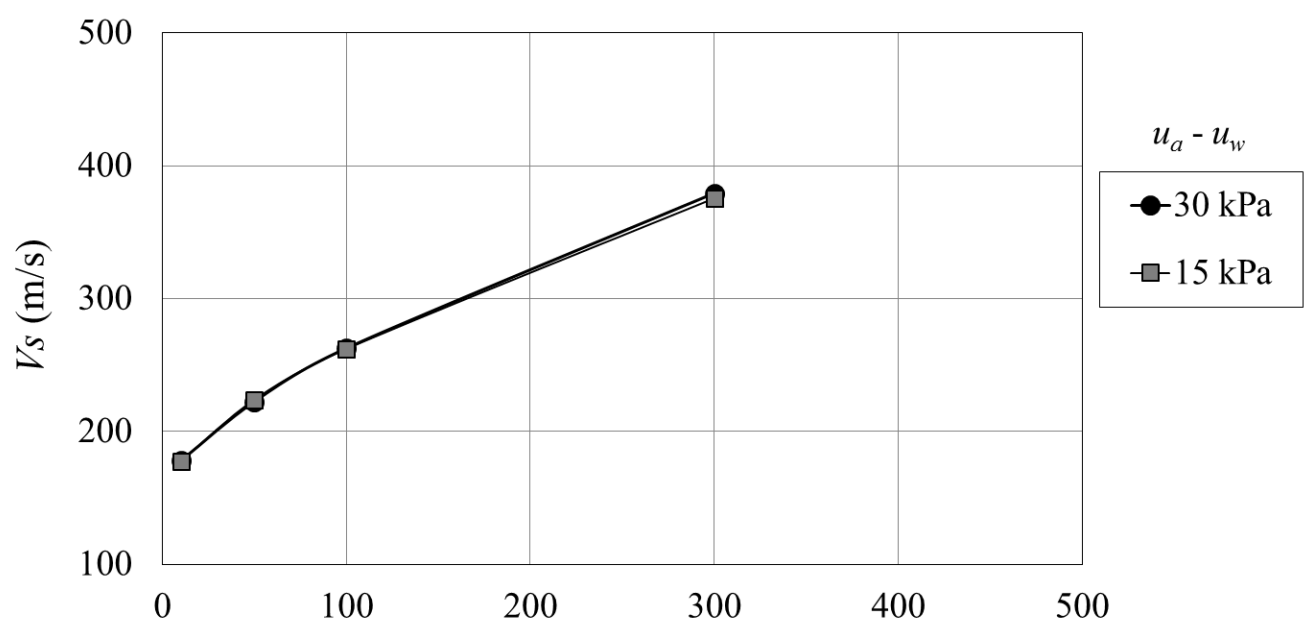

(c)

$$
\sigma_{3}-u_{a}(\mathrm{kPa})
$$

Figura 5.35. Velocidades de onda de cisalhamento para (a) o solo compactado com teores de umidade de $12,8 \%$ e (b) $13,9 \%$, e (c) para o solo indeformado. 


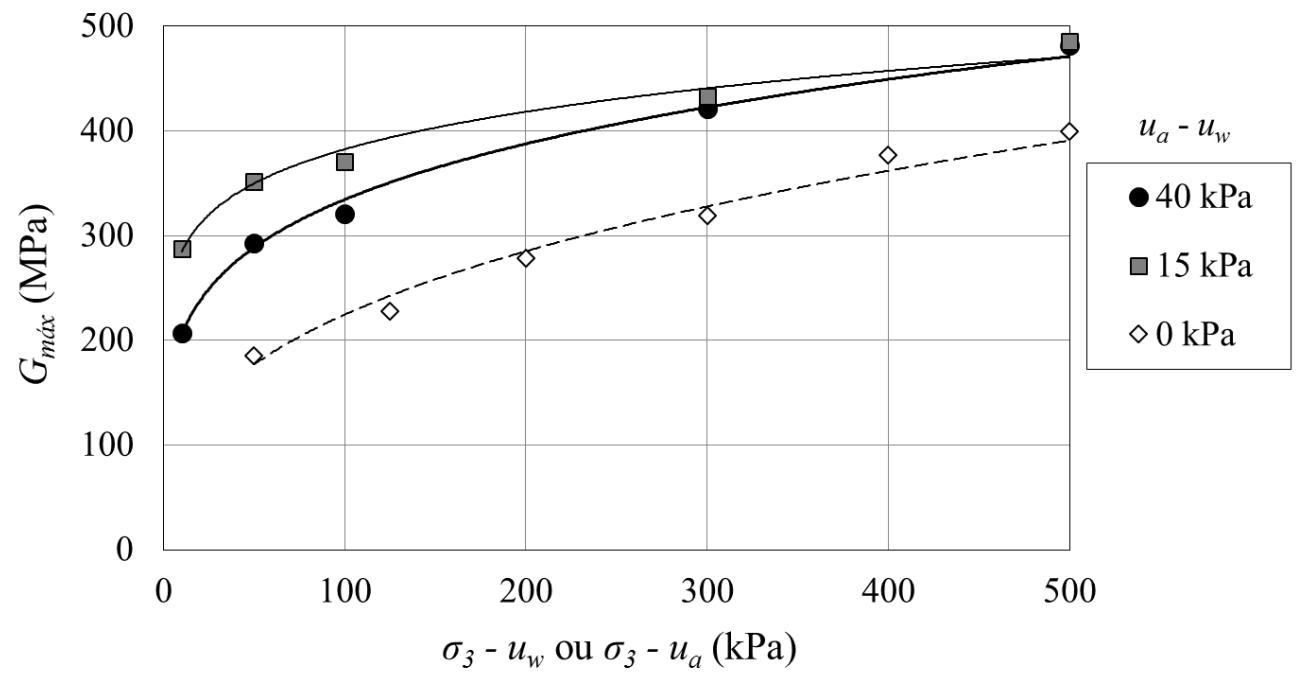

(a)

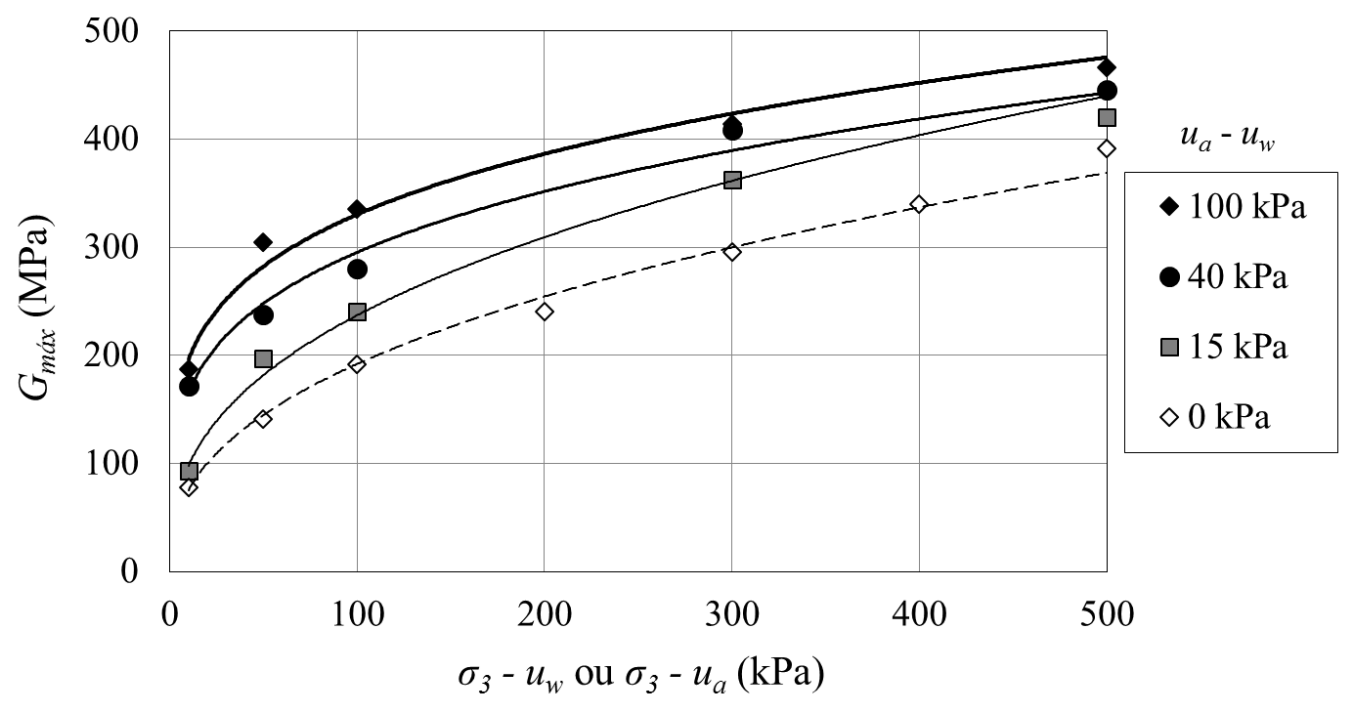

(b)

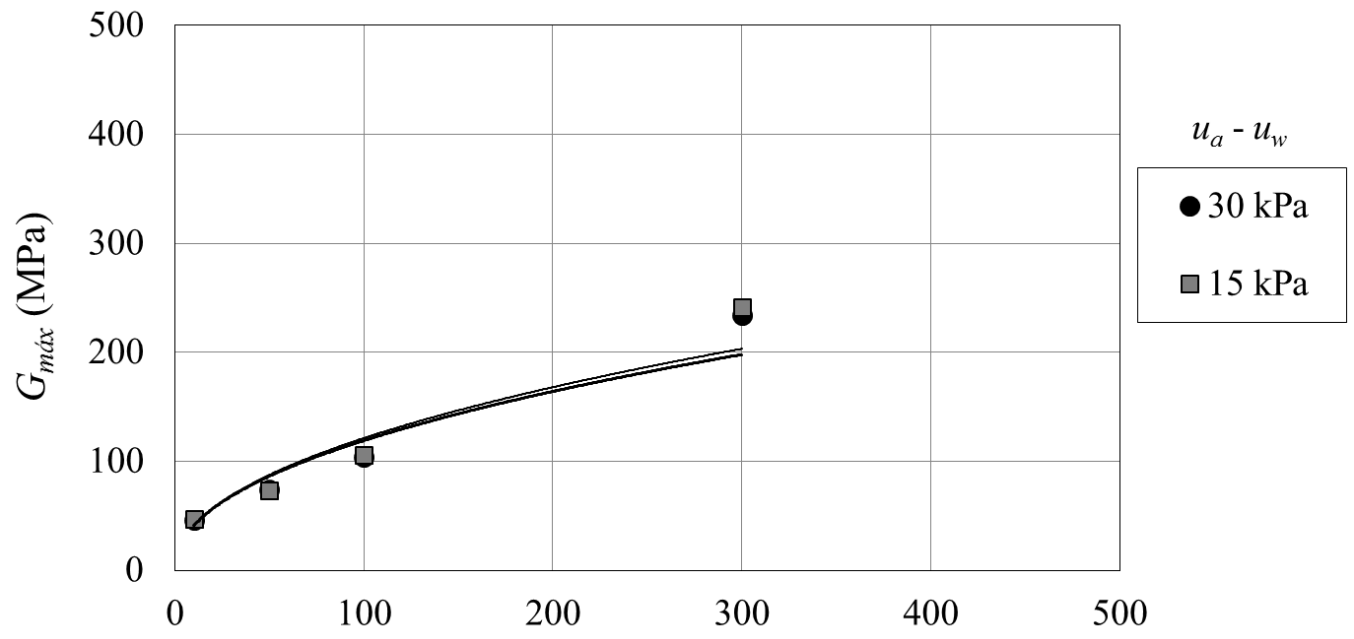

(c)

$$
\sigma_{3}-u_{a}(\mathrm{kPa})
$$

Figura 5.36. Módulo de cisalhamento máximo para (a) o solo compactado com teor de umidade de (a) $12,8 \%$ e (b) $13,9 \%$, e (c) para o solo indeformado. 
De modo geral, o que se nota na Figura 5.36 é que a sucção tende a diminuir a deformabilidade do solo, mas não altera a forma da relação $G_{m a ́ x} v s$ tensão de confinante líquida. $\mathrm{Na}$ maioria dos casos, a maior taxa de aumento de $G_{m a ́ x}$ foi observada entre as sucções de $0 \mathrm{e}$ $15 \mathrm{kPa}$, faixa onde se encontra a sucção de entrada de ar do solo. Os dados referentes aos ensaios com solo indeformado não indicam variação de deformabilidade com o aumento da sucção de 15 para $30 \mathrm{kPa}$, confirmando a análise da Figura 5.35.

Ainda na Figura 5.36, funções potenciais como a da Equação 5.2 foram novamente usadas para representar a relação entre $G_{m a ́ x}$ e o confinamento, desta vez para cada sucção. A Tabela 5.8 mostra os parâmetros de ajuste para os ensaios com solo não saturado. Para os ensaios com sucção nula, os parâmetros são os mesmos da Tabela 5.6.

Tabela 5.8. Parâmetros dos ajustes de modelos potenciais para os ensaios com solo não saturado (Eq. 5.2).

\begin{tabular}{ccccc}
\hline Amostra & $u_{a}-u_{w}(\mathrm{kPa})$ & $\beta_{1}^{*}$ & $\beta_{2}{ }^{*}$ & $r^{2}$ \\
\hline Compactada & 15 & 211,3 & 0,129 & 0,99 \\
$\left(w_{\text {médio }}=12,8 \%\right)$ & 40 & 125,5 & 0,213 & 0,99 \\
& 15 & 40,5 & 0,384 & 0,99 \\
Compactada & 40 & 92,5 & 0,252 & 0,99 \\
$\left(w_{\text {médio }}=13,9 \%\right)$ & 100 & 116,4 & 0,227 & 0,98 \\
& 15 & 13,9 & 0,470 & 0,93 \\
Indeformada & 30 & 14,1 & 0,463 & 0,94 \\
\hline \hline
\end{tabular}

* Parâmetros determinados para $G_{\text {máx }}$ em MPa e $\sigma_{3}-u_{w}$ em kPa.

Nestes modelos, o parâmetro $\beta_{1}$ pode ser associado ao posicionamento relativo das curvas para baixos confinamentos, quando a influência de $\beta_{2}$ é reduzida. Os valores de $\beta_{1}$ tenderam a ser maiores à medida que a sucção aumentou, com exceção dos ensaios com wmédio de 12,8\%. Já o parâmetro $\beta_{2}$ está relacionado à inclinação das curvas e seu valor foi maior para a condição saturada do que para a condição não saturada do solo compactado. Isto sugere que o solo não saturado é menos suscetível a variações em $G_{m a ́ x}$ quando se altera a tensão confinante em comparação ao solo saturado. Este comportamento pode ser atribuído à rigidez do esqueleto sólido proporcionada pela sucção.

Devido ao maior número de ensaios com bender elements em solo compactado com teor de umidade de 13,9\% em relação às demais condições de amostras, foi possível para este conjunto de ensaios analisar a influência das variáveis sucção e tensão confinante líquida sobre o módulo de cisalhamento máximo, o que resultou na seguinte equação: 


$$
G_{\text {máx }}=31042\left(\sigma_{3}-u_{a}\right)^{0,4}+\frac{10000\left(u_{a}-u_{w}\right)}{\left[2,3+0,057\left(u_{a}-u_{w}\right)\right]}[\mathrm{kPa}]
$$

onde $\sigma_{3}-u_{a}$ representa tanto a condição não saturada quanto a saturada $\left(\sigma_{3}-u_{w}\right)$, e cujo coeficiente de determinação foi de 0,98. A Figura 5.37 mostra representações gráficas desta equação e seu bom ajuste aos dados experimentais. Em (a), encontra-se uma vista tridimensional, em (b) e (c) são mostrados cortes nos planos módulo de cisalhamento máximo vs tensão confinante líquida e sucção, respectivamente. Esta equação sugere que uma função hiperbólica represente a variação de $G_{\text {máx }}$ com a sucção, o que implica o módulo tender assintóticamente a um limite. Embora a faixa de sucções testadas nesta pesquisa não seja suficiente para confirmar este comportamento, Mancuso et al. (2002) relata evidências experimentais de um limiar de $G_{m a ́ x}$ e discute um modelo físico que explica o fenômeno.

Comparando os resultados apresentados nas Figuras 5.36 e 5.37 com outros resultados experimentais da literatura, Mancuso et al. (2002) apresentou valores inferiores de $G_{m a ́ x}$ para uma areia siltosa compactada. Takkabutr (2006) obteve tendências similares de variação do módulo de cisalhamento máximo com a sucção. Alguns de seus resultados foram ilustrados na Figura 2.18. Um aumento não-linear do módulo de cisalhamento máximo com a sucção também foi verificado por Nyunt et al. (2011) em ensaios com areia. O autor identificou que a mudança no comportamento das curvas $G_{\text {máx }} v s$ sucção ocorreu próximo do valor de entrada de ar do solo, o que é provável que ocorra para o solo ensaiado nesta pesquisa, já que as maiores mudanças no módulo são observadas para baixas sucções.

Tratando-se de modelos para a representação dos resultados dos ensaios com bender elements, quando o módulo de cisalhamento máximo e a sucção são normalizados pela tensão confinante líquida, uma função potencial pode representar o conjunto de dados para cada condição de preparação de amostra:

$$
\frac{G_{\text {máx }}}{\left(\sigma_{3}-u_{a}\right)}=\kappa_{1}\left[\frac{\left(u_{a}-u_{w}+p_{a}\right)}{\left(\sigma_{3}-u_{a}\right)}\right]^{\kappa_{2}}
$$

na qual $\kappa_{1}$ e $\kappa_{2}$ são parâmetros empíricos e $p_{a}$ é a pressão atmosférica. A representação gráfica desta equação é apresentada na Figura 5.38. 

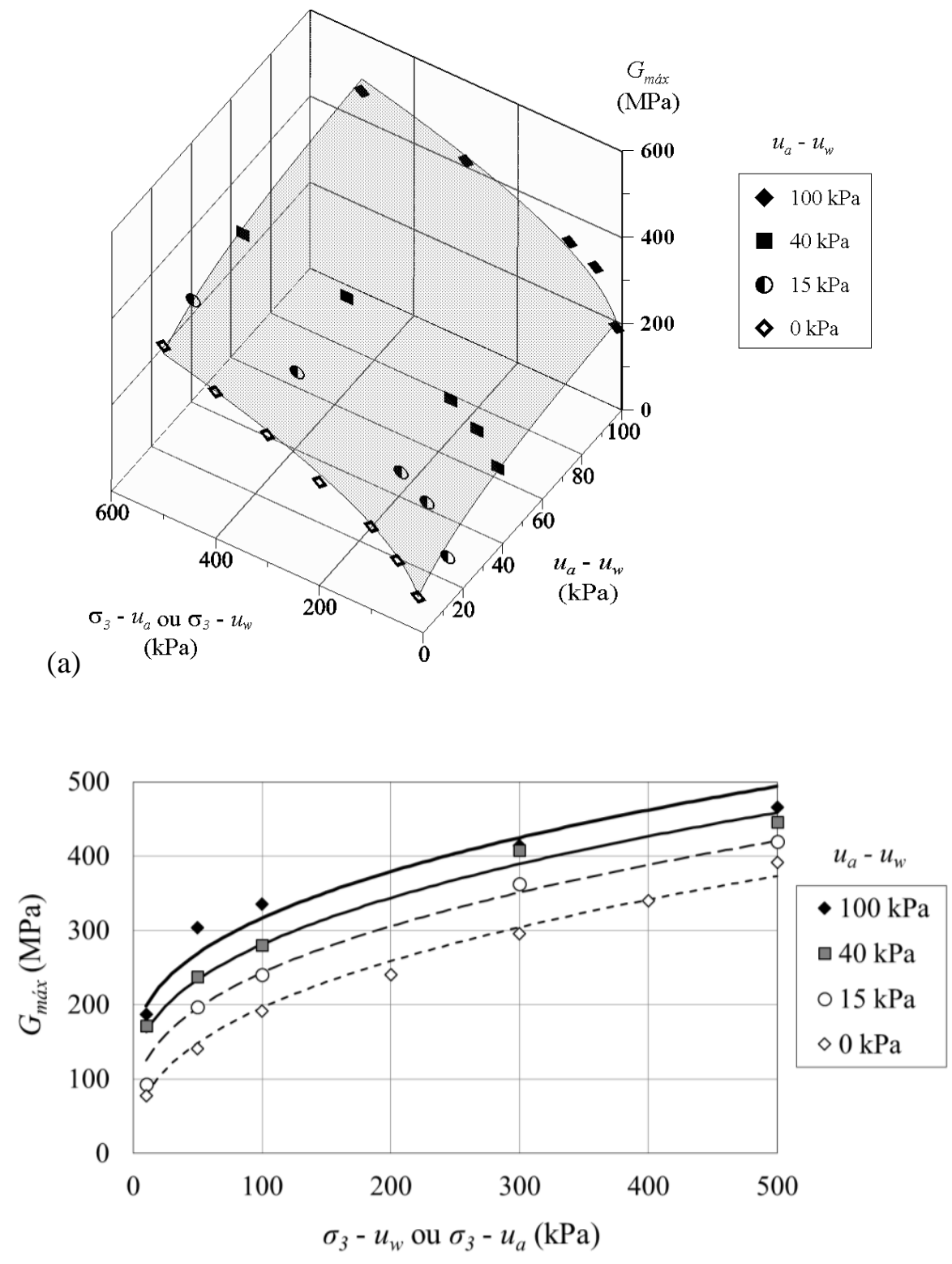

(b)

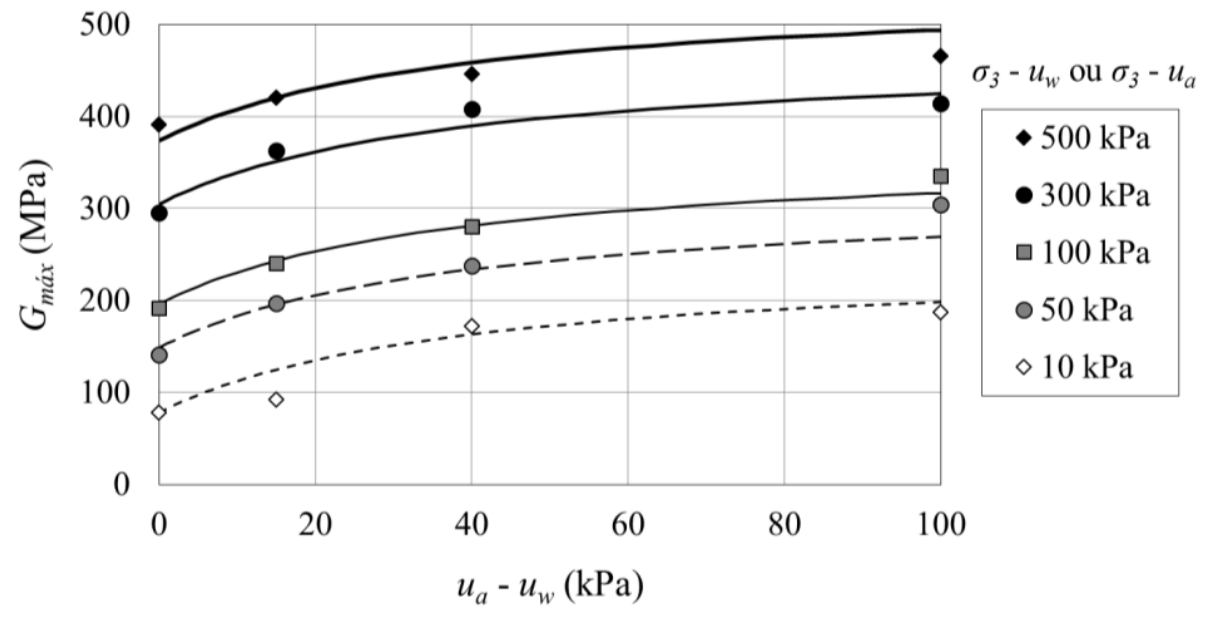

Figura 5.37. Módulo de cisalhamento máximo do solo compactado com teor de umidade de 13,9\%: (a) representação tridimensional, (b) influência da tensão confinante líquida e (c) da sucção. 


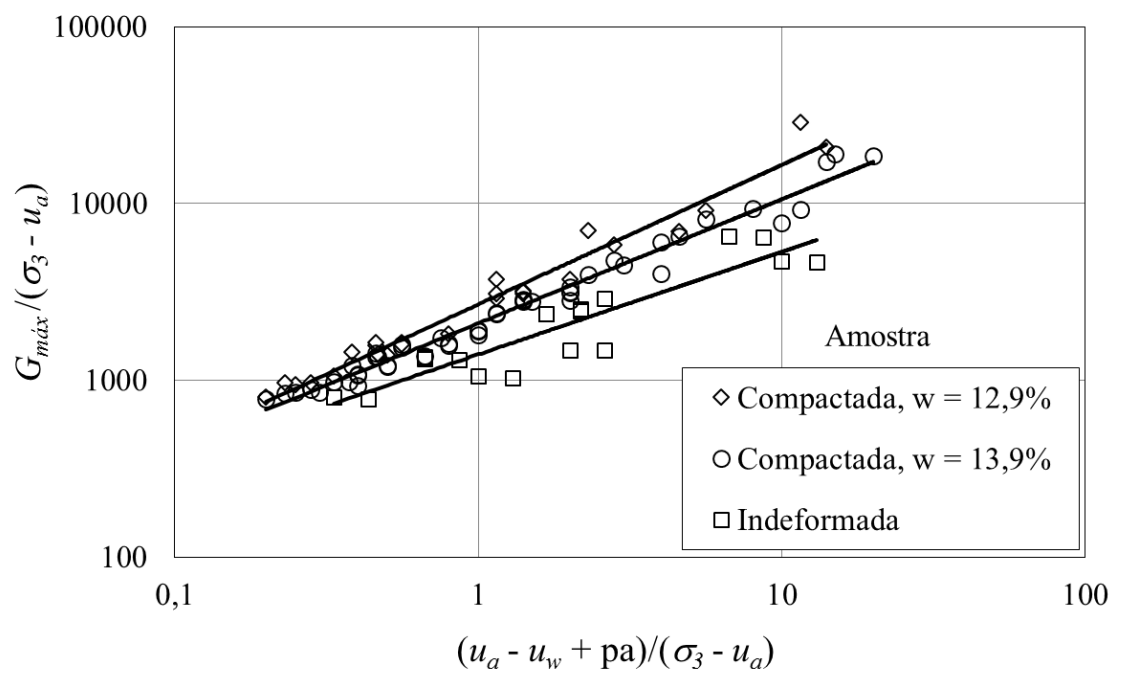

Figura 5.38. Normalização do módulo de cisalhamento máximo e da sucção pela tensão confinante.

Na Figura 5.38 foram introduzidos os dados referentes às trajetórias de confinamento, desconfinamento e reconfinamento de todos os ensaios com bender elements. À sucção foi somada a pressão atmosférica a fim de possibilitar a inserção dos dados dos corpos de prova com sucção zero. Ajustes aos pontos experimentais pelo método dos mínimos quadrados forneceram os parâmetros da Tabela 5.9. Estes parâmetros, juntamente com a representação gráfica do equacionamento, indicam que o solo compactado com teor de umidade de $12,8 \%$ é o menos deformável das amostras investigadas, seguido do solo compactado com teor de umidade de 13,9\%. Essas diferenças podem ser atribuídas à estrutura mais rija do solo compactado com teor de umidade abaixo da ótima em relação ao outro, e ao menor índice de vazios do solo compactado comparado ao indeformado.

Tabela 5.9. Parâmetros de ajustes potenciais para o módulo de cisalhamento máximo normalizado (Eq.

$$
5.4) \text {. }
$$

\begin{tabular}{cccc}
\hline \hline Amostra & $\kappa_{1}^{*}$ & $\kappa_{2}{ }^{*}$ & $r^{2}$ \\
\hline Compactada com $w_{\text {médio }}=12,8 \%$ & 2685 & 0,79 & 0,97 \\
Compactado com $w_{\text {médio }}=13,9 \%$ & 2101 & 0,70 & 0,98 \\
Indeformada & 1400 & 0,58 & 0,83
\end{tabular}

* Parâmetros determinados para $G_{\text {máx }}$ em MPa e as demais variáveis em kPa.

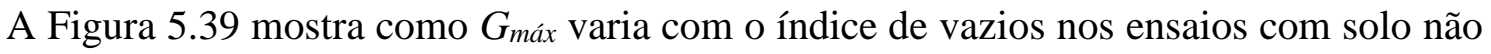
saturado. A sucção torna o solo menos deformável, e por consequência, menos suscetível a variações de volume com a trajetória de tensão. Na Figura 5.39 (b), por exemplo, onde se encontram ensaios com diferença de até $100 \mathrm{kPa}$ de sucção entre eles, o solo com sucção de 
$100 \mathrm{kPa}$ sofreu redução de 1,6\% no índice de vazios durante a trajetória de confinamento enquanto a redução foi de $8,1 \%$ no solo saturado. Para os corpos de prova indeformados, as variações no índice de vazios foram superiores às dos corpos de prova compactados devido aos primeiros possuírem estrutura mais porosa.

A Figura 5.40 mostra algumas das variações do módulo de cisalhamento máximo com a trajetória de tensão para o solo não saturado. São apresentadas as curvas referentes aos corpos de prova moldados em diferentes condições e ensaiados com sucção de $15 \mathrm{kPa}$. Mais uma vez, os dados não são conclusivos, já que em alguns casos, como o da Figura 5.40 (a), o solo se mostrou mais deformável quando sobreadensado. Já em (b), nota-se desprezível diferença entre os módulos de cisalhamento do solo compactado com teor de umidade de 13,9\%.

Para o corpo de prova de amostra indeformada em (c), no entanto, o índice de vazios inicial do solo $(1,05)$ é bastante reduzido na trajetória de confinamento, e o sobreadensamento causado no solo aumenta $G_{m a ́ x}$ em até cerca de $60 \%$. O efeito da trajetória de tensão verificado na amostra indeformada está de acordo com as observações experimentais de Vassallo et al. (2007).

\subsubsection{Degradação do módulo de cisalhamento do solo saturado}

A degradação do módulo de cisalhamento do solo compactado saturado foi obtida em ensaios triaxiais com instrumentação interna. Três ensaios foram realizados com os corpos de prova preparados nas condições mostradas na Tabela 5.10. As curvas tensão e deformação volumétrica $v s$ deformação axial são apresentadas na Figura 5.41 para deformações axiais de até $2 \%$. As deformações volumétricas foram calculadas como

$$
\varepsilon_{v}=2 \varepsilon_{r}+\varepsilon_{a}
$$

onde $\varepsilon_{r}$ é a deformação radial.

Nota-se na Figura 5.41 (a) curvas muito próximas às obtidas na Figura 5.12, a qual mostra resultados de amostras preparadas nas mesmas condições e que foram ensaiadas em câmara triaxial de parede dupla. Quanto às deformações volumétricas, os ensaios com 100 e $300 \mathrm{kPa}$ de tensão confinante líquida apresentaram respostas bastante próximas, enquanto para $\sigma_{3}-u_{w}$ de $50 \mathrm{kPa}$ as deformações foram mais elevadas. É possível perceber que neste caso, a deformação axial teve papel predominante, já que $\varepsilon_{v}$ é da mesma ordem de $\varepsilon_{a}$. 


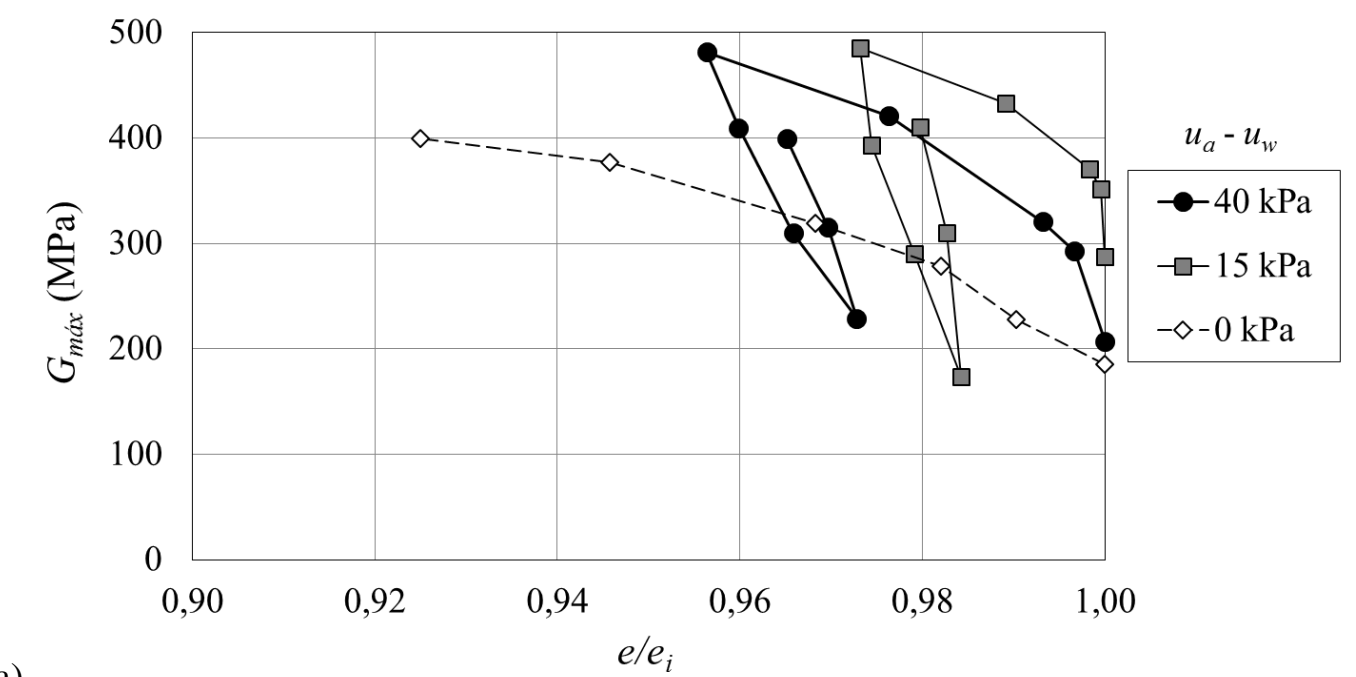

(a)

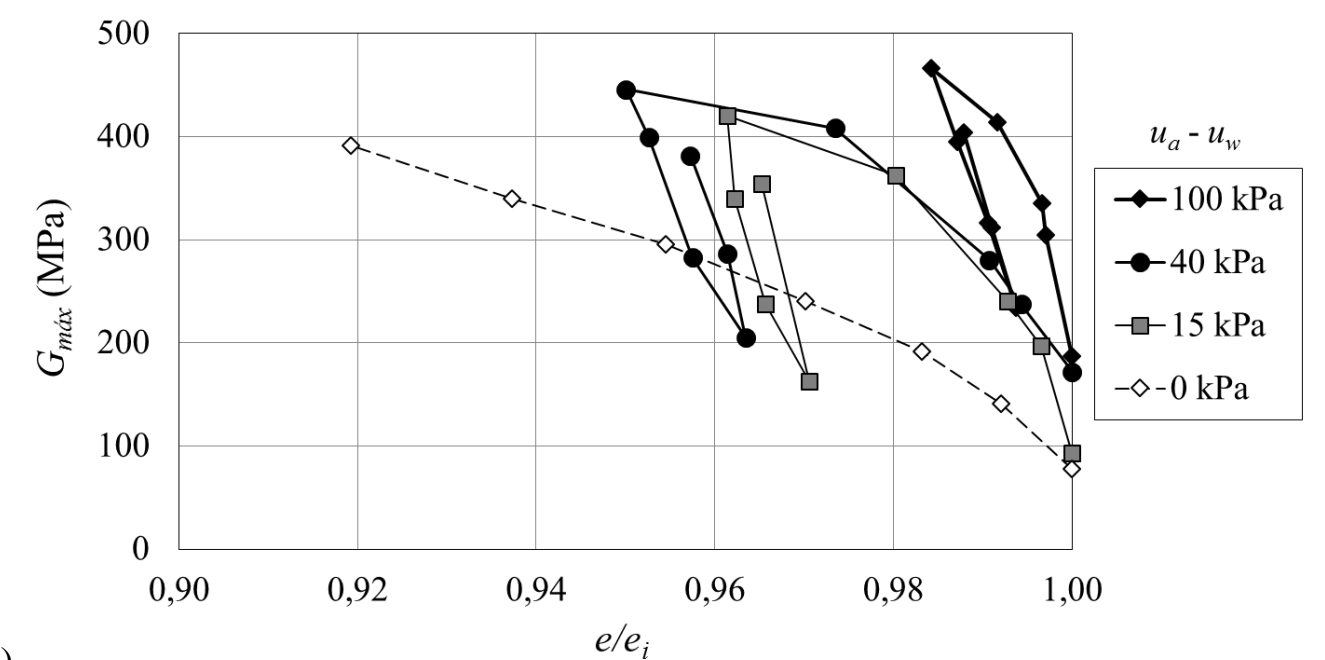

(b)

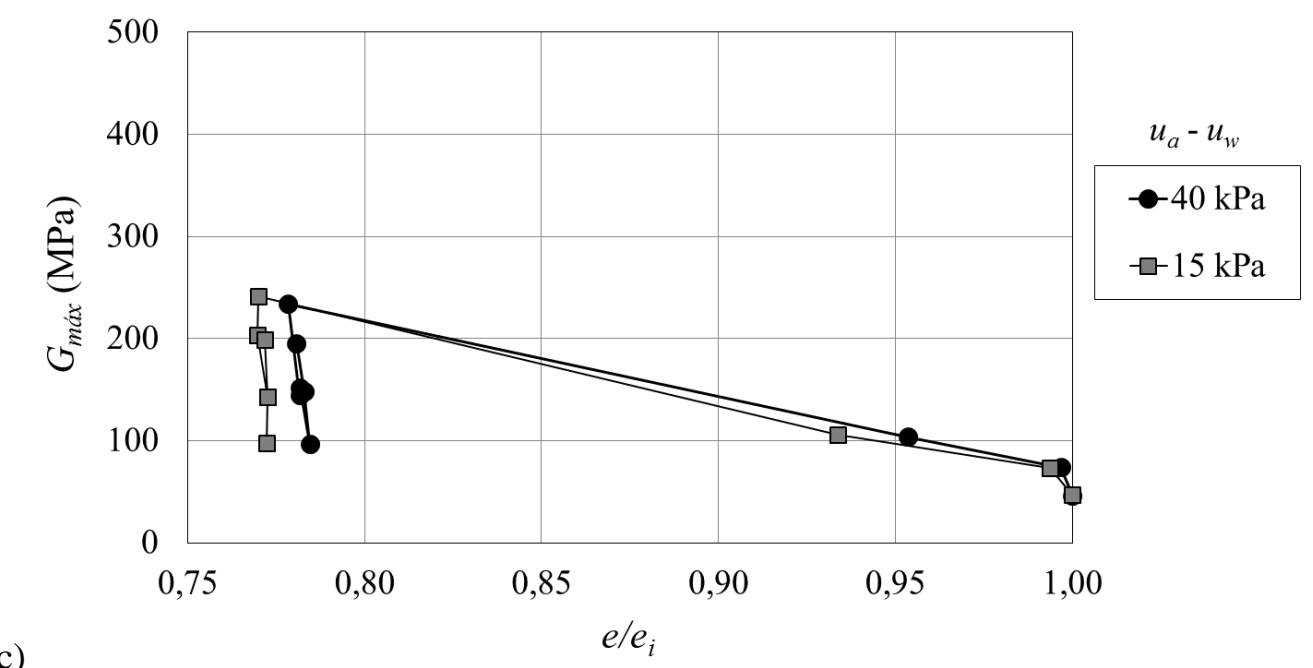

Figura 5.39. Variação do módulo de cisalhamento máximo com a relação entre índice de vazios e índice de vazios inicial (a) para o solo compactado com teores de umidade de $12,8 \%$ e (b) $13,9 \%$, e (c) para o solo indeformado. 


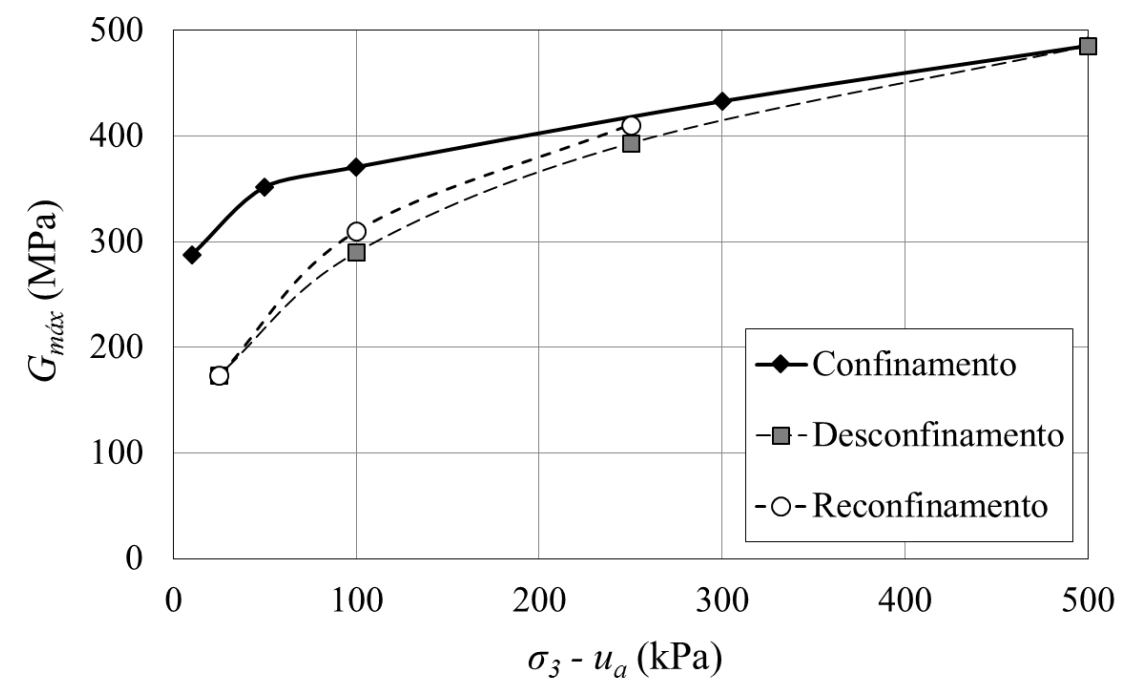

(a)

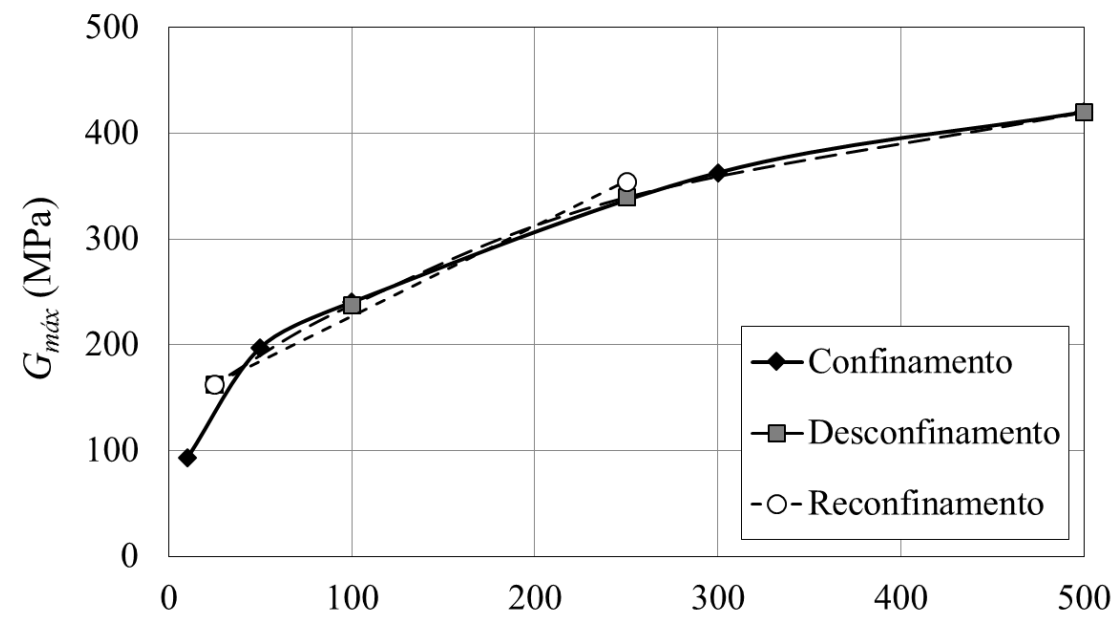

(b)

$$
\sigma_{3}-u_{a}(\mathrm{kPa})
$$

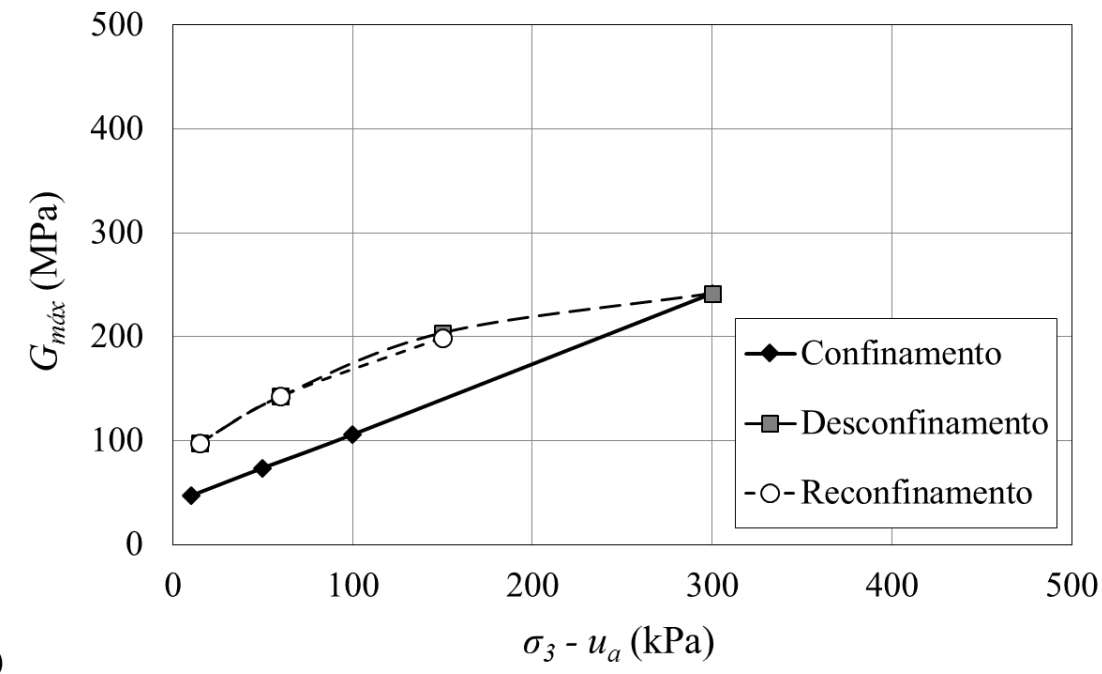

Figura 5.40. Variação do módulo de cisalhamento máximo com a trajetória de tensão (a) para solo compactado com teores de umidade de $12,8 \%$ e (b) $13,9 \%$, e (c) para o solo indeformado e ensaiado com sucção de $15 \mathrm{kPa}$. 
Tabela 5.10. Índices físicos de moldagem dos corpos de prova compactados para ensaio de deformabilidade em compressão triaxial em condição saturada.

\begin{tabular}{ccccc}
\hline \hline$\sigma_{3}-u_{w}(\mathrm{kPa})$ & $w(\%)$ & $\rho_{d}\left(\mathrm{~g} / \mathrm{cm}^{3}\right)$ & $S_{r}(\%)$ & $e$ \\
\hline 50 & 14,1 & 1,706 & 68,3 & 0,547 \\
100 & 13,9 & 1,723 & 68,3 & 0,532 \\
300 & 13,9 & 1,707 & 67,4 & 0,546 \\
\hline \hline
\end{tabular}

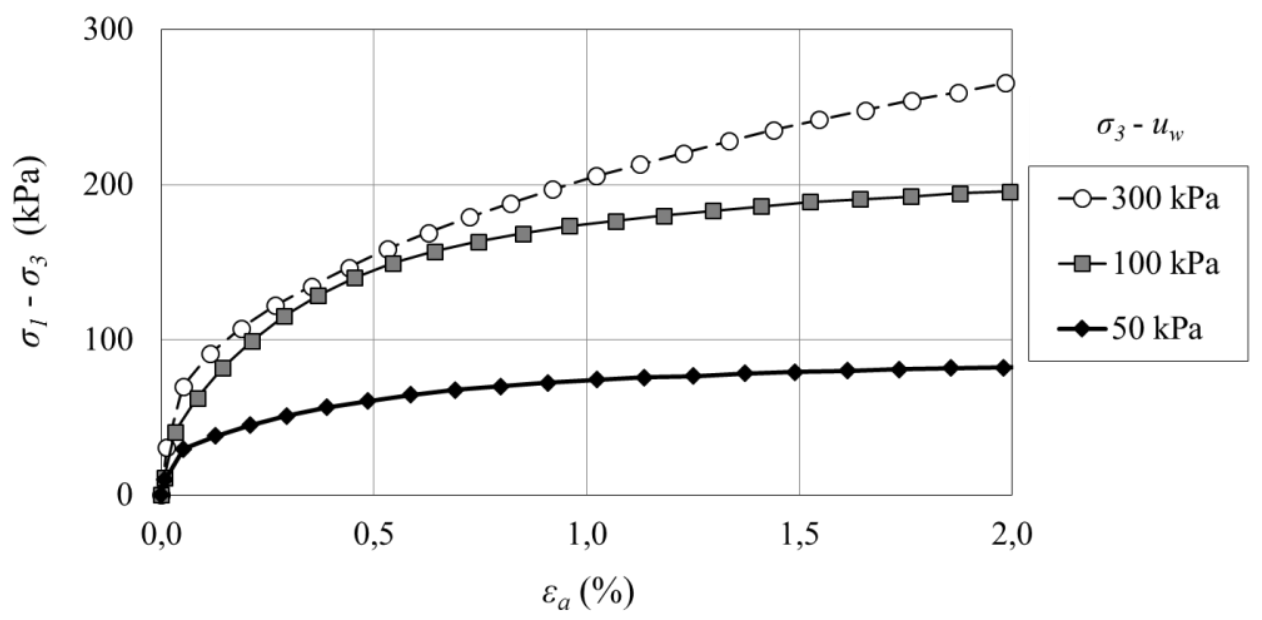

(a)

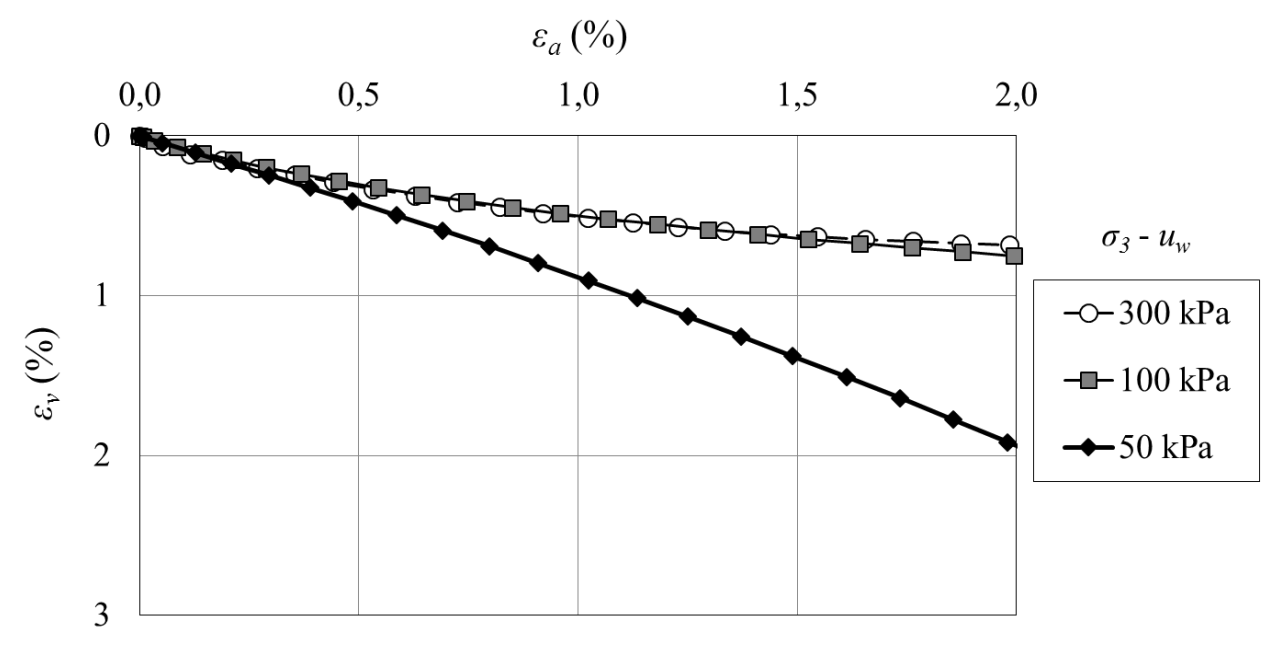

(b)

Figura 5.41. (a) Curvas tensão $v s$ deformação axial e (b) deformação volumétrica vs deformação axial dos ensaios CD com instrumentação interna.

Dos dados de tensão e deformações foram calculados a deformação cisalhante, $\gamma$, e o módulo de cisalhamento secante, $G_{s e c}$ como:

$$
\gamma=\left(\varepsilon_{a}-\varepsilon_{r}\right)
$$




$$
G_{\mathrm{sec}}=\frac{1}{2} \frac{\Delta\left(\sigma_{1}-\sigma_{3}\right)}{\Delta \gamma}
$$

Os resultados são mostrados na Figura 5.42 para deformações cisalhantes em torno de $0,01 \%$ a $1 \%$. O conjunto de resultados é complementado por módulos de cisalhamento máximos medidos em ensaios com bender elements para corpos de prova preparados e ensaiados nas mesmas condições. A estes módulos de cisalhamento máximos foi associada uma deformação cisalhante de $0,001 \%$, que foi relatada como a máxima deformação provocada nos ensaios com bender elements (Dyvik e Madshus, 1985). Na Figura 5.42 (a) nota-se que os maiores módulos de cisalhamento são consistentemente relacionados às maiores tensões confinantes. Para as deformações acima de $0,1 \%$ as curvas se aproximam, independentemente da tensão confinante, e o módulo de cisalhamento assume valores inferiores a $40 \mathrm{MPa}$. A redução da influência do confinamento com a degradação do módulo também foi observada por Leong et al. (2006).

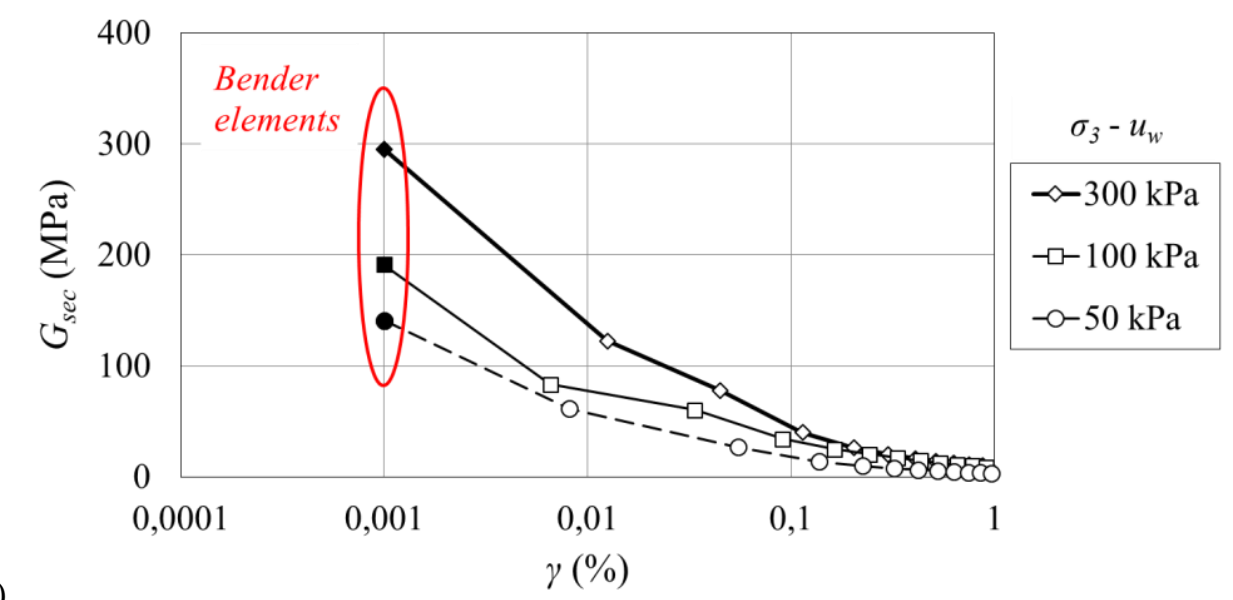

(a)

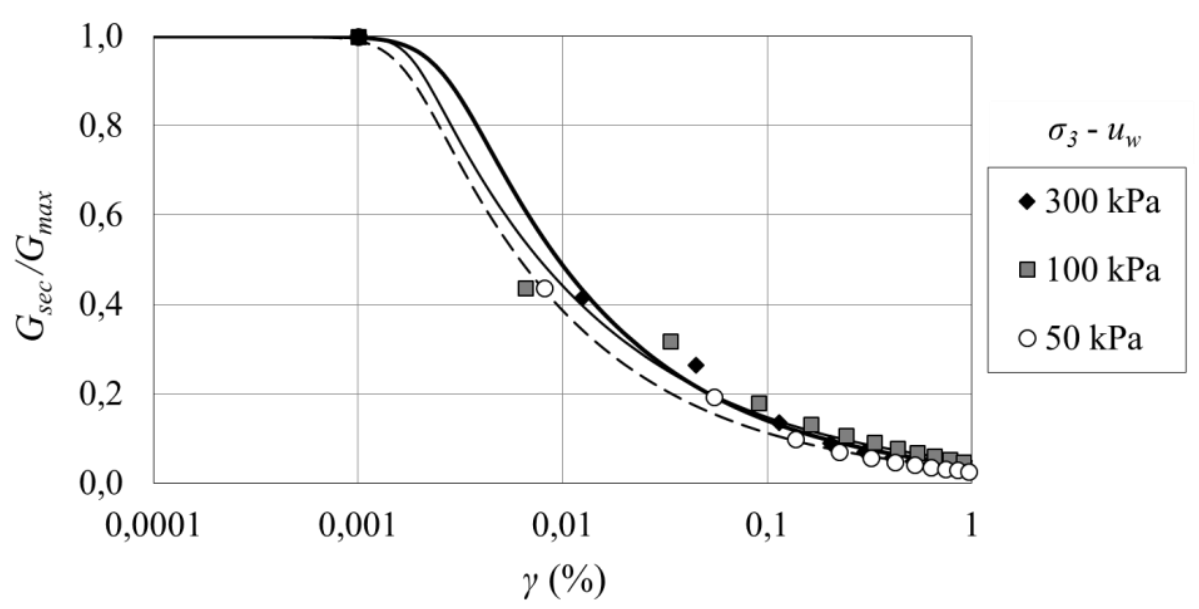

Figura 5.42. (a) Degradação do módulo de cisalhamento e do (b) módulo de cisalhamento normalizado do solo compactado saturado. 
A Figura 5.42 (b) mostra a degradação do módulo de cisalhamento normalizado juntamente com ajustes da função:

$$
\frac{G}{G_{\text {máx }}}=\frac{1}{\left[1+\eta_{1} \cdot \gamma^{\eta_{2}}\right]^{\eta_{3}}}
$$

onde $\eta_{1}, \eta_{2}$ e $\eta_{3}$ são parâmetros empíricos e $\gamma$ é a deformação cisalhante em porcentagem. Para os ensaios de compressão triaxial, $G$ foi tomado como $G_{s e c}$. A mesma função foi usada por Borden et al. (1996), Hoyos et al. (2004) e Leong et al. (2006) para modelar resultados experimentais. Os ajustes foram calculados pelo método de mínimos quadrados e os parâmetros obtidos podem ser vistos na Tabela 5.11 .

Tabela 5.11. Índices físicos dos corpos de prova compactados para ensaio de deformabilidade em compressão triaxial em condição não saturada (Eq. 5.8).

\begin{tabular}{ccccc}
\hline \hline$\sigma_{3}-u_{w}(\mathrm{kPa})$ & $\eta_{1}$ & $\eta_{2}$ & $\eta_{3}$ & $r^{2}$ \\
\hline 50 & $6,33 \cdot 10^{21}$ & 4,57 & 0,12 & 0,99 \\
100 & $1,88.10^{32}$ & 6,80 & 0,07 & 0,98 \\
300 & $2,00.10^{18}$ & 4,00 & 0,14 & 0,99 \\
\hline \hline
\end{tabular}

Se a deformação cisalhante no limiar do trecho elástico da curva $\left(\gamma_{\text {lim }}\right)$ é tomado como a deformação associada a $G_{s e c} / G_{m a ́ x}$ de 0,99 (Vucetic, 1994), o modelo sugere que $\gamma_{l i m}$ é em média 0,001\% para o solo saturado. Além disso, observa-se na Figura 5.42 (b) que nos primeiros dados registrados pelos transdutores de efeito Hall, em torno de $0,01 \%$ de deformação, o módulo de cisalhamento secante já corresponde a apenas cerca de $40 \%$ de $G_{m a ́ x}$, definido por ensaios com bender elements. Ainda nesta figura, confirma-se que a influência do confinamento pode ser desprezada quando as deformações são superiores a $0,1 \%$, dada a sobreposição das curvas. Neste caso, $G_{s e c} / G_{m a ́ x}$ é inferior a 0,2 .

\subsubsection{Degradação do módulo de cisalhamento e amortecimento do solo não saturado}

Ensaios de coluna ressonante em corpos de prova com sucção e com teor de umidade constantes forneceram dados de degradação do módulo de cisalhamento do solo não saturado. O primeiro, sob condições drenadas, e o segundo, não drenadas. Os índices físicos de moldagem dos corpos de prova usados nestes ensaios encontram-se na Tabela 5.12. 
Tabela 5.12. Índices físicos de moldagem dos corpos de prova compactados para ensaio em coluna ressonante em condição não saturada.

\begin{tabular}{cccccc}
\hline \hline Ensaio & $u_{a}-u_{w}(\mathrm{kPa})^{*}$ & $w(\%)$ & $\rho_{d}\left(\mathrm{~g} / \mathrm{cm}^{3}\right)$ & $S_{r}(\%)$ & $e$ \\
\hline Coluna & 15 & 13,5 & 1,723 & 66,4 & 0,532 \\
ressonante com & 40 & 14,0 & 1,732 & 69,8 & 0,524 \\
sucção constante & 100 & 14,0 & 1,718 & 68,2 & 0,537 \\
& 4 & 18,9 & 1,689 & 88,2 & 0,569 \\
Coluna & 7 & 13,9 & 1,715 & 67,9 & 0,539 \\
ressonante com & 7 & 11,4 & 1,736 & 57,6 & 0,526 \\
teor de umidade & 7 & 14,0 & 1,719 & 68,5 & 0,542 \\
constante & 7 & 14,0 & 1,729 & 69,7 & 0,532 \\
& 7 & 14,0 & 1,716 & 68,2 & 0,544 \\
& 7 & 14,0 & 1,719 & 68,5 & 0,541 \\
\hline \hline
\end{tabular}

* Sucção de ensaio para os ensaios com sucção constante ou sucção inicial para os ensaios com teor de umidade constante.

Respostas de frequência típicas obtidas a partir dos ensaios de coluna ressonante com sucção constante são mostrados na Figura 5.43. Em (a) apresentam-se resultados de três corpos de prova ensaiados sob mesma tensão confinante líquida $(50 \mathrm{kPa})$, mesmo torque $(1000 \mathrm{Nm})$ e diferentes sucções. Estes resultados mostram o aumento da frequência de ressonância $\left(f_{r}\right)$ e a redução da deformação cisalhante máxima causados pelo aumento da sucção no solo. A Figura 5.43 (b), apresenta resultados do corpo de prova com sucção de $15 \mathrm{kPa}$ quando torques crescentes foram aplicados ao solo. Os crescentes carregamentos induziram aumento nas deformações e consequente plastificação no solo. A plastificação do solo, por sua vez, se reflete na alteração de sua deformabilidade, que pode ser observada nesta figura pela redução de $f_{r}$. A curva backbone reúne as diferentes frequências de ressonância e suas correspondentes deformações cisalhantes. Sua inclinação na direção de menores valores de frequência também indica a degradação do módulo de cisalhamento do solo.

Nesta etapa em que vibrações forçadas foram aplicadas ao solo, ciclos de torque $v s$ deformação foram registados quando se atingiu a frequência de ressonância. A Figura 5.44 mostra estes ciclos, chamados laçadas de histerese, para um torque de $1000 \mathrm{Nm}$ e sucções de 15 e $100 \mathrm{kPa}$. As respectivas frequências de ressonância foram 184 e $240 \mathrm{~Hz}$. Ao comparar a inclinação das linhas tracejadas nos gráficos, é possível observar o enrijecimento do solo com aumento da sucção, já que um mesmo carregamento induz menores deformações para maiores sucções. 

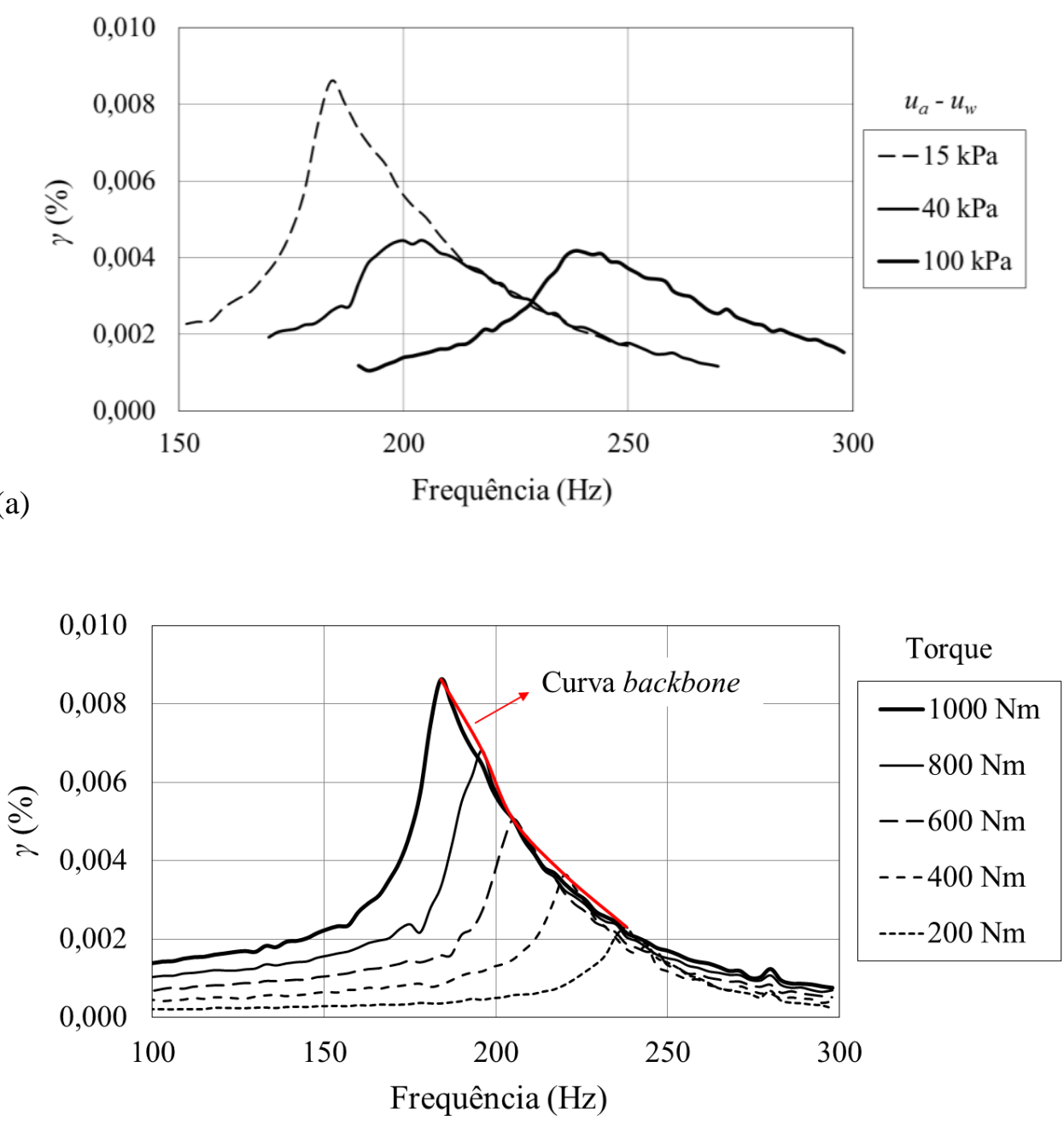

Figura 5.43. (a) Efeitos típicos da sucção e (b) do torque na resposta de frequência do solo em ensaios de coluna ressonante com sucção constante.

Ao final da etapa de vibrações forçadas com a varredura de frequências, foi permitido ao solo vibrar livremente enquanto dados de deformação $v s$ tempo eram registrados. A Figura 5.45 mostra alguns exemplos desses dados que foram coletados após uma vibração forçada com torque de $1000 \mathrm{Nm}$. Esta figura ilustra o comportamento subamortecido do sistema soloequipamento, no qual a amplitude das oscilações diminui gradualmente a zero.

A razão de amortecimento do solo pode ser calculada a partir do decaimento da amplitude em vibrações livres, dos ciclos de vibrações forçadas e das respostas de frequência. Nesta pesquisa optou-se por utilizar o método de largura de banda, que estima a razão de amortecimento do solo a partir das respostas de frequência do solo. Com relação ao módulo de cisalhamento, nos ensaios de coluna ressonante esta propriedade foi calculada a partir da Eq. 2.15 com $V_{s}$ obtido por 


$$
\frac{I}{I_{0}}=\left(\frac{2 \pi \cdot f_{r} \cdot L}{V_{s}}\right) \operatorname{tg}\left(\frac{2 \pi \cdot f_{r} \cdot L}{V_{s}}\right)
$$

em que $I$ é o momento polar de inércia de massa do corpo de prova, $I_{0}$ é o momento polar de inércia de massa do cabeçote e da placa de fixação do sistema oscilador no cabeçote, e $L$ é o comprimento do corpo de prova (Richart et al., 1970).

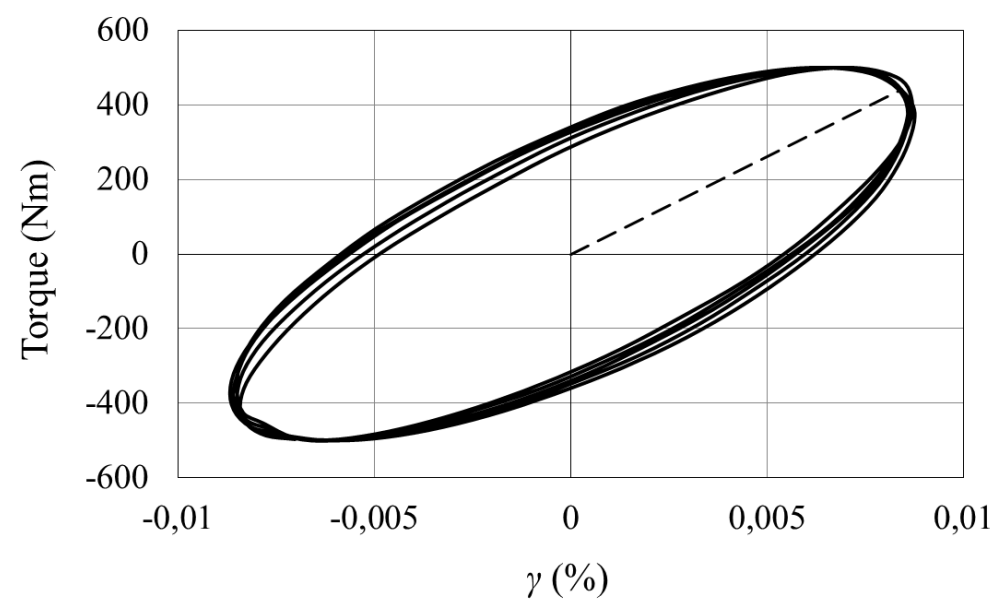

(a)

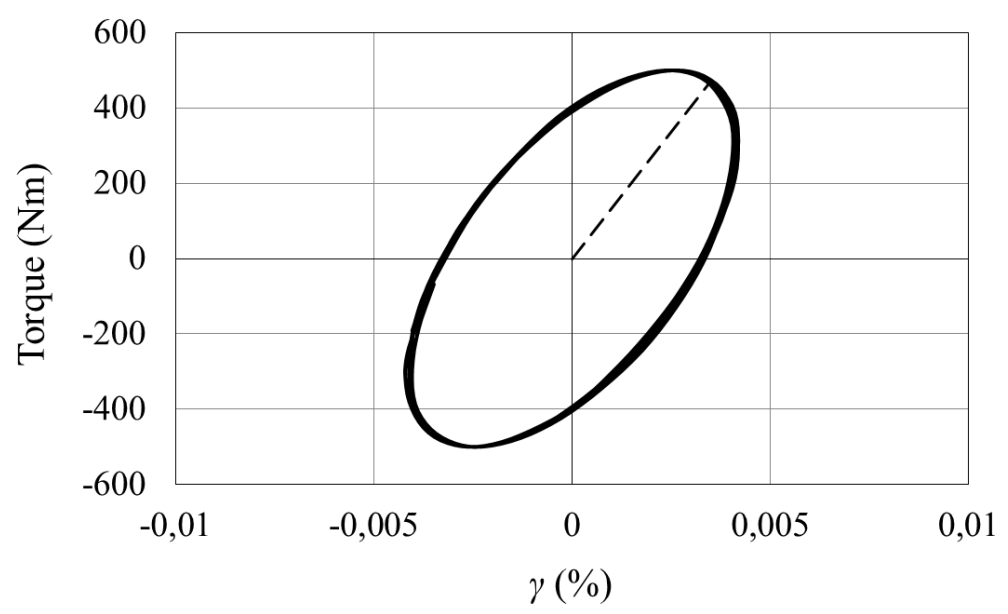

Figura 5.44. Laçadas de histerese dos corpos de prova com sucções de (a) 15 e (b) $100 \mathrm{kPa}$.

A Figura 5.46 apresenta os dados de variação da deformabilidade com a deformação cisalhante para os ensaios de coluna ressonante com sucção constante. Nestes ensaios, o módulo de cisalhamento foi degradado até cerca de $60 \%$ do seu máximo, enquanto a razão de amortecimento $(D)$ aumentou para até duas vezes o seu valor mínimo $\left(D_{\min }\right)$. Os módulos de cisalhamento máximos calculados a partir destes ensaios foram de 152, 153 e $211 \mathrm{MPa}$ para as sucções de 15, 40 e $100 \mathrm{kPa}$, respectivamente. Razões de amortecimento mínimos foram de 
$2,4 \%$ e $4,3 \%$ para as sucções de 15 e $40 \mathrm{kPa}$. Os resultados mostram $D / D_{\min }$ muito semelhantes para estas sucções.

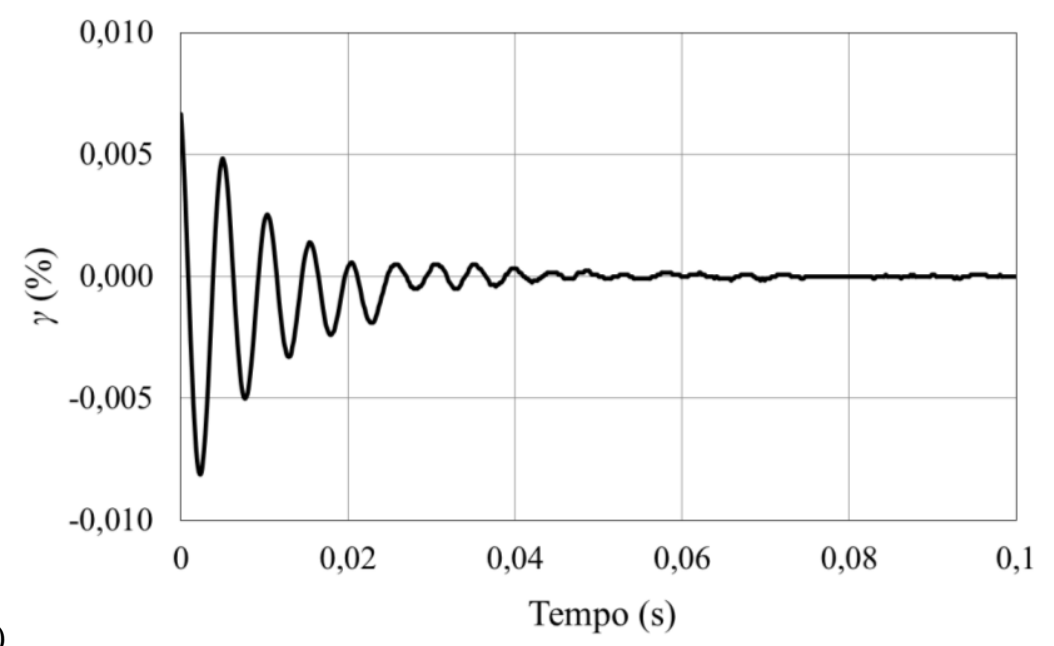

(a)

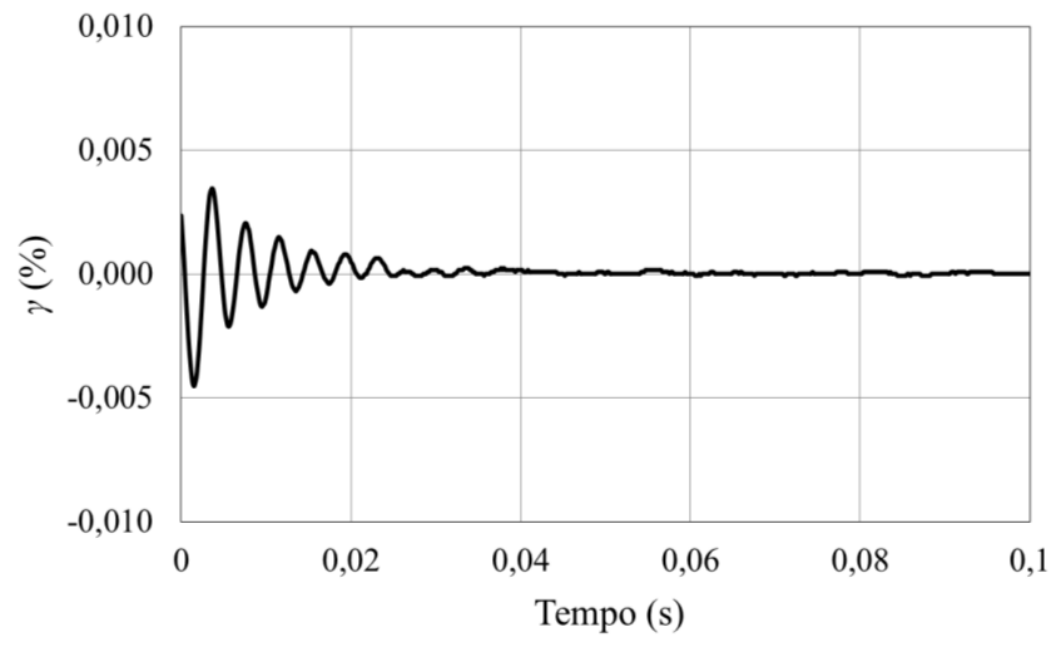

Figura 5.45. Decaimento das vibrações livres para os corpos de prova com sucções de (a) 15 e (b) 100 $\mathrm{kPa}$.

A evolução da deformabilidade do solo não saturado foi modelada pela Eq. 5.8 e

$$
\frac{D}{D_{\min }}=\left[1+\mu_{1} \cdot \gamma^{\mu_{2}}\right]^{\mu_{3}}
$$

onde $\mu_{1}, \mu_{2}$ e $\mu_{3}$ são parâmetros empíricos. Esta é a função inversa da Eq. 5.8, que foi previamente utilizada para reproduzir a degradação módulo de cisalhamento no item 5.3.3. Os parâmetros experimentais obtidos por mínimos quadrados são mostrados na Tabela 5.13, onde pode-se ver novamente os elevados coeficientes de determinação, indicando a adequação de 
tais funções para representar os resultados experimentais. No entanto, a estimativa da degradação do amortecimento do solo além dos limites de dados experimentais não parece ser apropriada. Isso porque as tendências observadas para além desses limites apontam para um comportamento oposto ao esperado. De acordo com a teoria da Dinâmica dos Solos, quanto mais deformável o material, maior será o amortecimento. Todavia, a Figura 5.46 (b) indica um aumento do amortecimento a taxas maiores para o solo com maior sucção quando $D / D_{\min }$ é maior do que 2. Na Figura 5.46 (a), as curvas correspondentes a $G / G_{m a ́ x}$ para 40 e $100 \mathrm{kPa}$ de sucção estão aparentemente sobrepostas, apesar dos distintos parâmetros de ajuste.

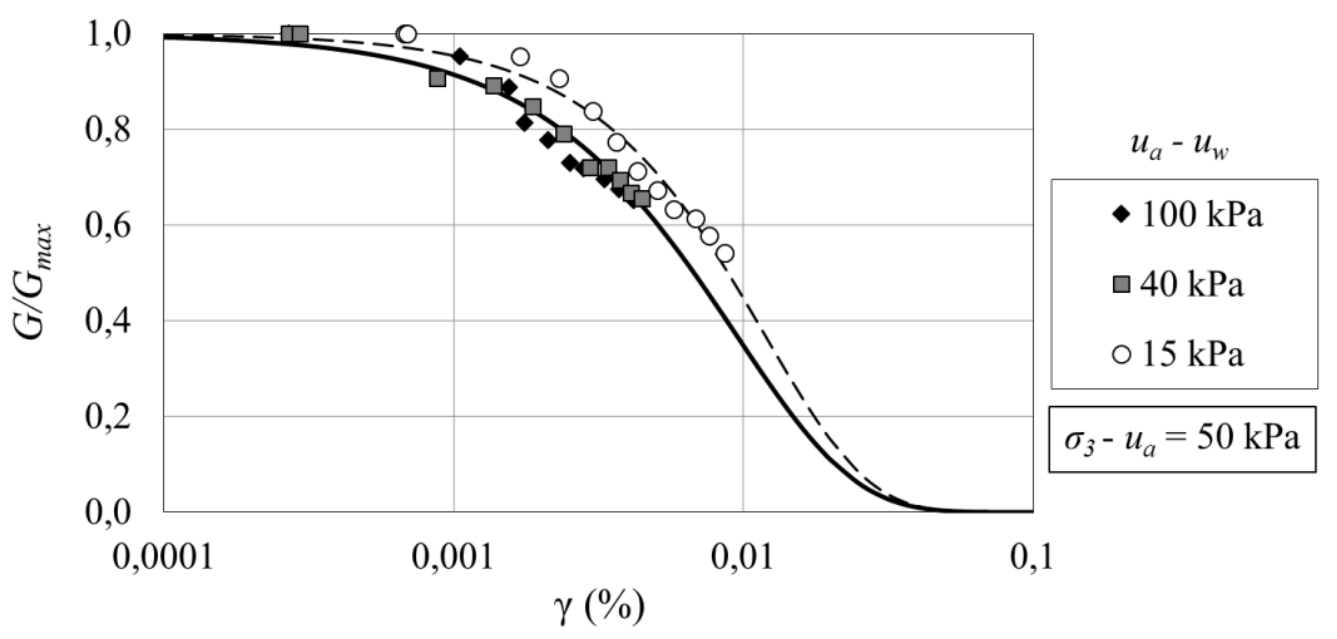

(a)

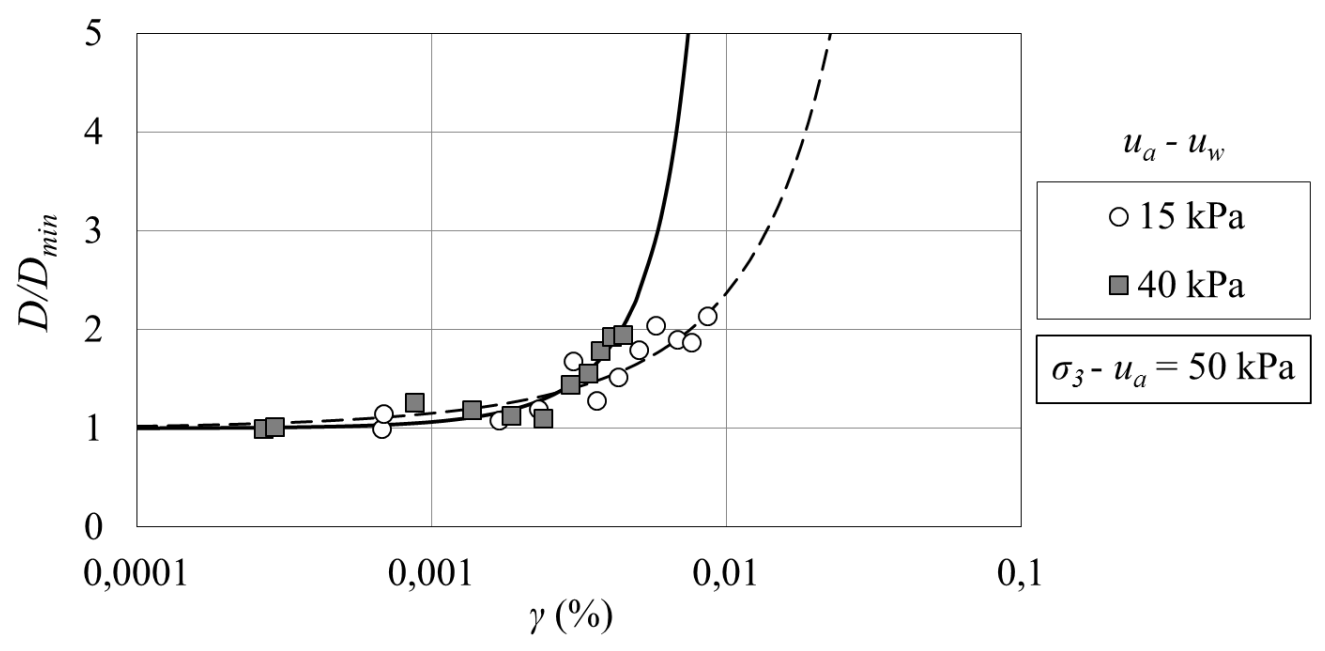

(b)

Figura 5.46. (a) Curvas de degradação do módulo de cisalhamento e (b) razão de amortecimento normalizados dos ensaios de coluna ressonante com sucção constante. 
Tabela 5.13. Parâmetros de ajuste das curvas $G / G_{\max }$ e $D / D_{\min } v s \gamma$ dos ensaios de coluna ressonante com sucção constante (Eq. 5.8 e 5.10).

\begin{tabular}{|c|c|c|c|c|c|c|}
\hline Curva & $u_{a}-u_{w}(\mathrm{kPa})$ & $\sigma_{3}-u_{a}(\mathrm{kPa})$ & $\eta_{1}$ & $\eta_{2}$ & $\eta_{3}$ & $r^{2}$ \\
\hline \multirow{3}{*}{$G / G_{\max } v s \gamma$} & 15 & 50 & 240,30 & 1,23 & 289,00 & 0,97 \\
\hline & 40 & 50 & 131,90 & 1,07 & 157,70 & 0,99 \\
\hline & 100 & 50 & 197,14 & 1,14 & 234,51 & 0,96 \\
\hline \multirow{3}{*}{$D / D_{\min } v s \gamma$} & & & $\mu_{1}$ & $\mu_{2}$ & $\mu_{3}$ & \\
\hline & 15 & 50 & 31,50 & 0,78 & 35,81 & 0,84 \\
\hline & 40 & 50 & 2519,66 & 1,62 & 2985,78 & 0,92 \\
\hline
\end{tabular}

Em relação aos ensaios de coluna ressonante com teor de umidade constante, a Figura 5.47 apresenta alguns resultados típicos. Em (a) mostra-se a resposta a muito pequenas deformações do corpo de prova com $7 \mathrm{kPa}$ de sucção inicial para uma voltagem de entrada de $0,25 \mathrm{~V}$. Devido às muito pequenas deformações provocadas por tal voltagem $(0,0018 \% \mathrm{em}$ média), o módulo de cisalhamento foi tomado como máximo e o coeficiente de amortecimento foi tomado como mínimo neste ponto. Pode ser observado na Figura 5.47 (a) que a tensão confinante aumenta a frequência de ressonância do solo, mostrando o enrijecimento do material. A Figura 5.47 (b) mostra os resultados de um mesmo corpo de prova sob tensão de confinamento de $500 \mathrm{kPa}$, onde se pode observar as crescentes voltagens de saída do acelerômetro que indicam aumento das deformações cisalhantes no solo. A curva backbone mostra uma ligeira verticalização, sugerindo que o carregamento causado por esta faixa de voltagens de entrada não afete significativamente as propriedades de deformabilidade deste corpo de prova.

Os dados coletados durante as fases de confinamento, quando muito pequenas deformações foram induzidas no solo, permitiu uma avaliação das variações de $G_{m a ́ x}$ e $D_{\text {mín }}$ com o tempo. O módulo de cisalhamento foi calculado a partir das frequências de ressonância (Eq. 5.9 e 2.15), e a razão de amortecimento foi calculada pelo método de largura de banda. A Figura 5.48 exemplifica as mudanças nas propriedades de deformabilidade a muito pequenas deformações na amostra com 7 kPa de sucção inicial.

Pode-se notar na Figura 5.48 (a), que em cerca de 24 horas o $G_{m a ́ x}$ aumentou em $28 \%$ quando a tensão confinante $\left(\sigma_{3}\right)$ foi de $10 \mathrm{kPa}$, e em $8 \%$, quando $\sigma_{3}$ foi de $500 \mathrm{kPa}$. Para outras tensões confinantes, percentuais de aumento intermediários foram observados, e estes foram progressivamente menores à medida que $\sigma_{3}$ aumentou. Na Figura 5.48 (b), a razão de amortecimento mínimo exibe tendência de diminuição com o tempo e a tensão confinante. De fato, quanto menor for a deformabilidade do material, menor atenuação do movimento é 
esperada. O percentual de variação de $D_{\min }$ ficou entre 12 e $28 \%$ no período de 24 horas para este corpo de prova. A maior parte das alterações nas propriedades deformacionais ocorreu dentro das primeiras 5 horas de confinamento, o que indica que o período de 24 horas foi suficiente para comprimir este solo sob condições não drenadas. Efeito similar do tempo de confinamento sobre a deformabilidade do solo foi observado por Hoyos et al. (2004) em ensaios com argila quimicamente estabilizada.

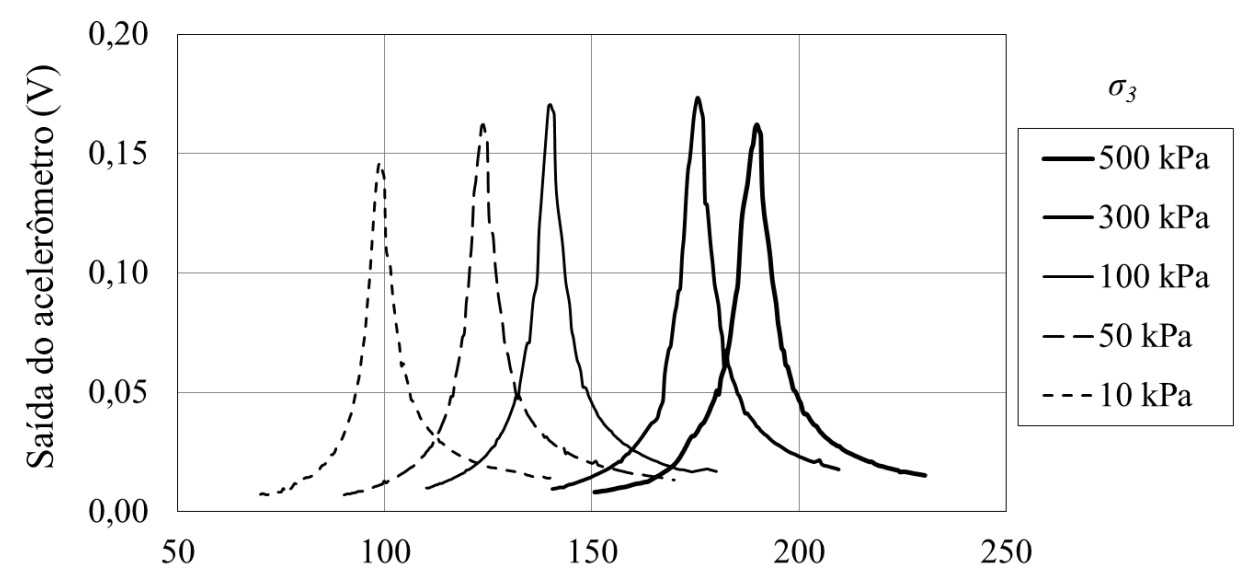

(a)

Frequência $(\mathrm{Hz})$

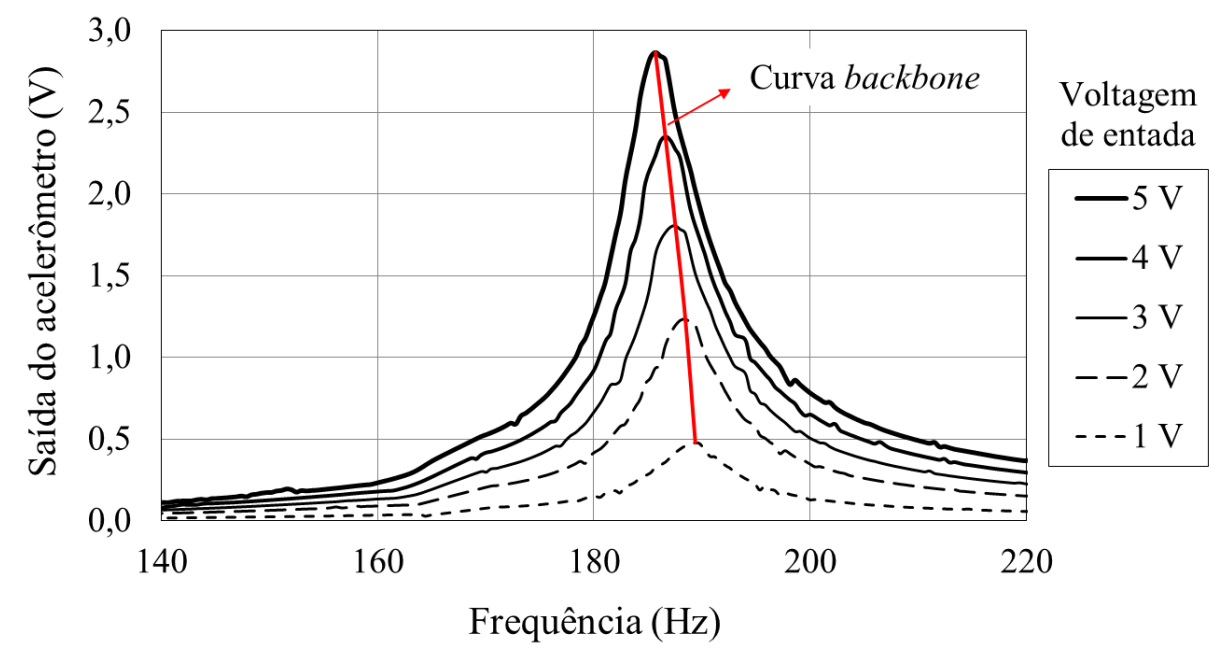

Figura 5.47. (a) Efeito típico da tensão confinante e (b) da voltagem de entrada na resposta de frequência dos ensaios de coluna ressonante com teor de umidade constante.

O módulo de cisalhamento máximo e a razão de amortecimento mínimo no final de cada fase de confinamento foram plotados contra a tensão confinante na Figura 5.49. Ajustes de funções de potência, como exemplificado na Eq. 5.2, são apresentados em conjunto com os dados experimentais para indicar as tendências. Os parâmetros de ajuste encontram-se na 
Tabela 5.14. Observa-se na Figura 5.49 (a), a tendência de $G_{m a ́ x}$ aumentar com a tensão de confinamento e a sucção inicial, como já foi notado quando se analisaram os dados dos ensaios de bender elements (Figura 5.36). Além disso, os valores de $G_{m a ́ x}$ estão razoavelmente próximos quando se comparam os dois métodos de ensaio. Outras comparações entre técnicas de ensaio, são apresentadas no item 5.3.5.

(a)

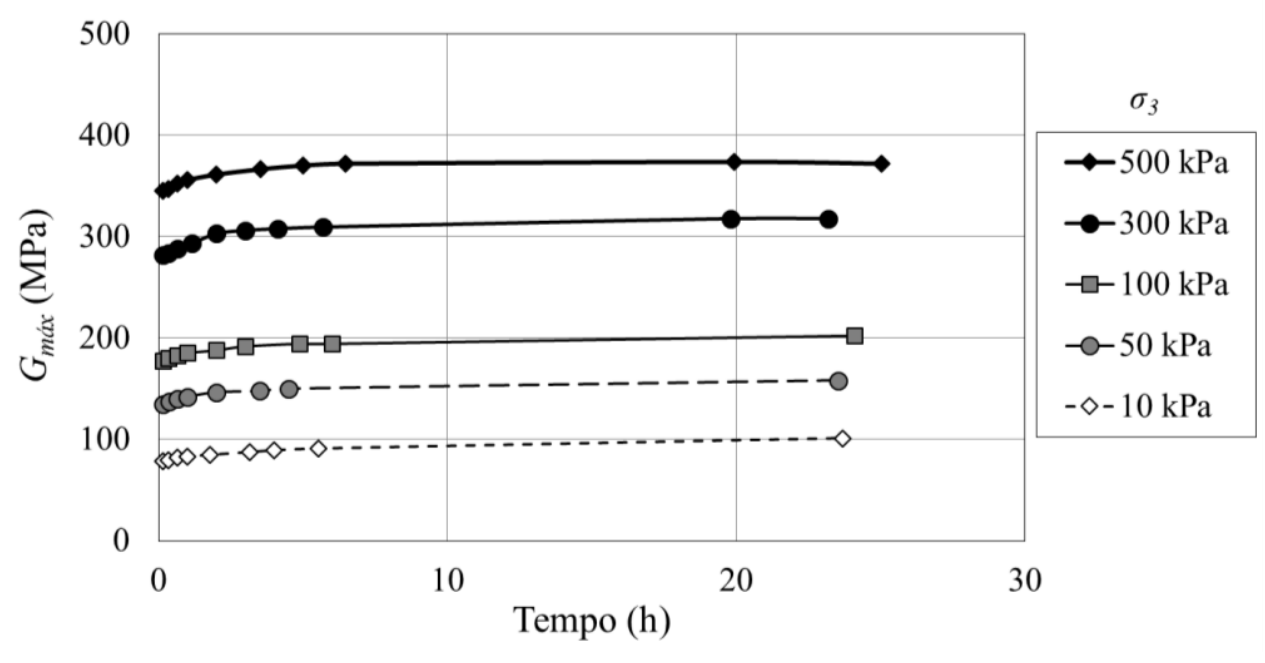

(b)

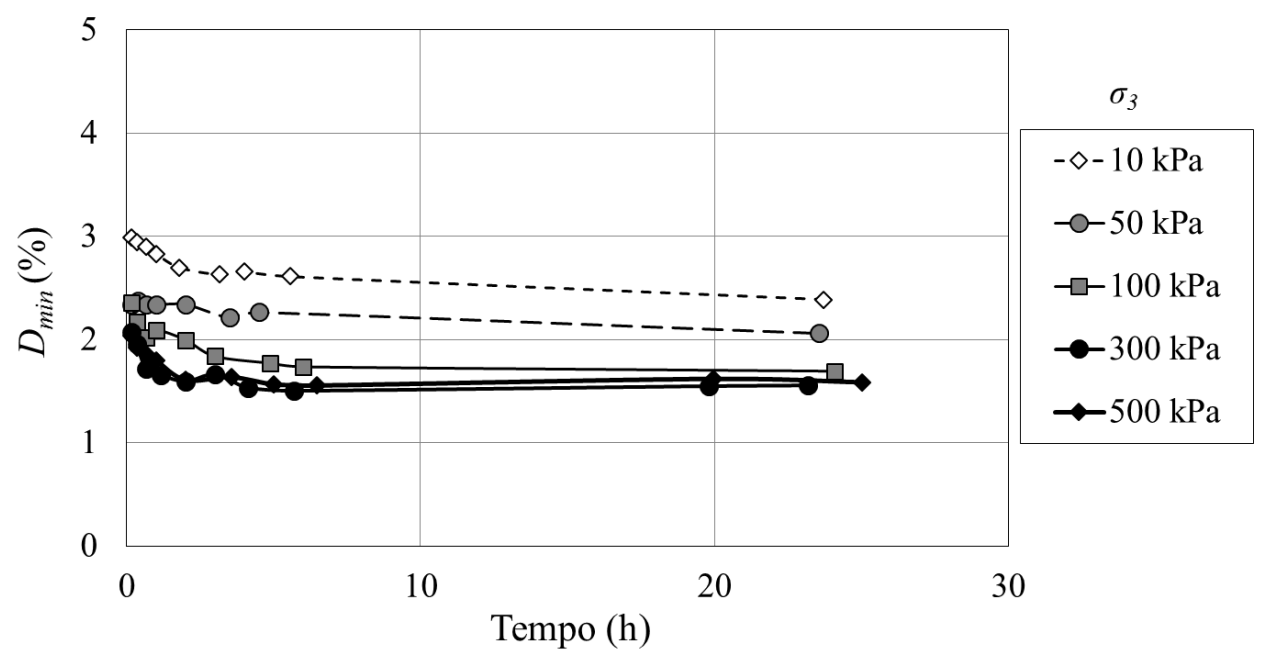

Figura 5.48. Efeito típico do tempo de equilíbrio (a) no módulo de cisalhamento máximo e (b) na razão de amortecimento mínimo do solo.

A Figura 5.49 (b) mostra a razão de amortecimento mínimo do solo variando entre $1 \mathrm{e}$ $4 \%$. Nesta figura, é possível notar como a tensão confinante influencia $D_{\text {min }}$, embora não esteja claro como sucção afeta essa propriedade. Analisando os dados para diferentes sucções em cada tensão confinante (ou seja, linhas verticais no gráfico), observa-se $D_{\min }$ variando menos de $1 \%$ 
em todos os casos. Isto está de acordo com as baixas magnitudes de $D_{\min }$ encontrados por Madhusudhan e Kumar (2013), que ensaiaram areias com diferentes graus de saturação.

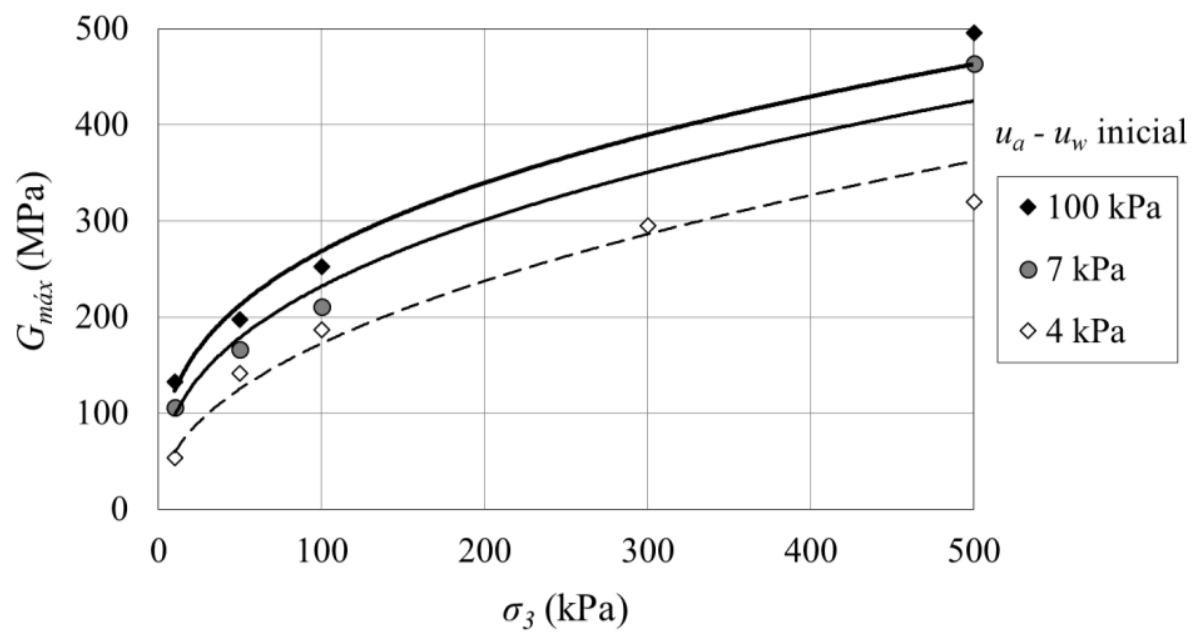

(a)

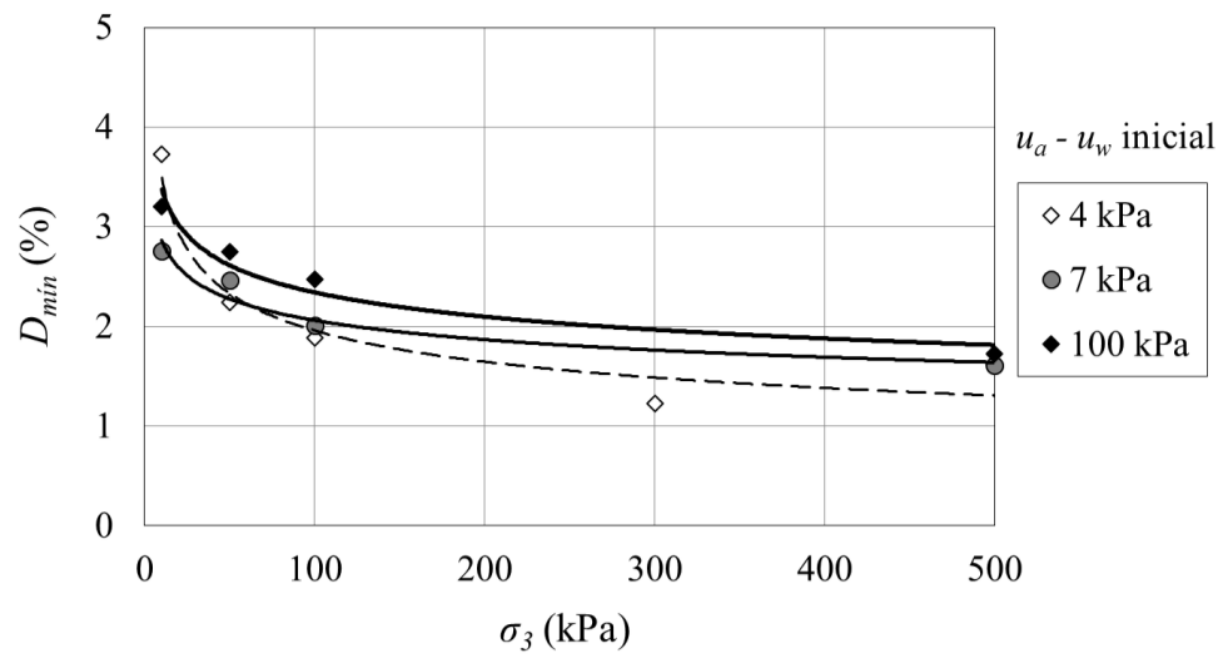

Figura 5.49. Influência da tensão confinante e sucção no módulo de cisalhamento máximo e na razão de amortecimento mínimo dos ensaios de coluna ressonante com teor de umidade constante.

Tabela 5.14. Parâmetros dos ajustes de modelos potenciais para os ensaios com solo compactado não saturado em ensaios de coluna ressonante com teor de umidade constante (Eq. 5.2).

\begin{tabular}{ccccc}
\hline \hline Curva & $u_{a}-u_{w}$ inicial $(\mathrm{kPa})$ & $\beta_{1}$ & $\beta_{2}$ & $r^{2}$ \\
\hline \multirow{3}{*}{$G_{\max }$ vs $\sigma_{3}$} & 4 & 20,7 & 0,461 & 0,97 \\
& 7 & 38,8 & 0,396 & 0,97 \\
& 100 & 58,7 & 0,326 & 0,97 \\
$D_{\min } v s \sigma_{3}$ & 4 & 6,2 & $-0,251$ & 0,87 \\
& 7 & 4,0 & $-0,145$ & 0,96 \\
\hline \hline
\end{tabular}


Como procedimento final nos ensaios de coluna ressonante com teor de umidade constante, deformações cisalhantes mais elevadas foram induzidas no solo com $500 \mathrm{kPa}$ de confinamento, e as degradações do módulo de cisalhamento e da razão de amortecimento foram determinadas. As deformações cisalhantes foram calculadas como

$$
\gamma=\frac{\sqrt{2} D_{c p} \cdot \theta_{\text {máx }}}{L}
$$

onde $D_{c p}$ é o diâmetro do corpo de prova, e $\theta_{\text {máx }}$ é o deslocamento angular máximo

$$
\theta_{\text {máx }}=\frac{2 \sqrt{2} g}{5} \frac{A_{\text {máx }}}{\left(2 \pi \cdot f_{r}\right)^{2}}
$$

em que $g$ é a aceleração da gravidade e $A_{\text {máx }}$ é a voltagem de saída de pico.

As Figuras 5.50 (a) e (b) apresentam a evolução da deformabilidade em função da sucção inicial. A figuras mostram as tendências gerais esperadas de variações do módulo de cisalhamento e do amortecimento com a deformação cisalhante, embora alguma discrepância seja observada nos dados de amortecimento para a maior sucção inicial, de $100 \mathrm{kPa}$.

Uma representação comum da degradação do módulo é aquela na qual $G$ é normalizado por $G_{\text {máx }}$ (como mostrado na Figura 5.46, por exemplo). No entanto, esta não é uma representação conveniente para os dados na Figura 5.50 (a), devido à pequena variação do módulo de cisalhamento apresentada pelos corpos de prova sob $500 \mathrm{kPa}$ de tensão confinante. O valor mínimo de $G / G_{m a ́ x}$ obtido experimentalmente para estes corpos de prova foi de 0,90 . As deformações cisalhantes no limiar elástico foram em média $0,003 \%$.

Ao se relacionar a Figura 5.50 (b), com as curvas de razão de amortecimento para areias apresentadas por Seed e Idriss (1970), os dados deste solo arenoso estão próximos à curva de limite inferior, ligeiramente deslocados para a esquerda. Isto se deve aos maiores $\gamma_{\text {lim }}$ obtidos para este solo. Essa comparação indica a consistência dos resultados da Figura 5.50 (b), já que maiores $\gamma_{\text {lim }}$ são esperados para solos com maiores índices de plasticidade (Vucetic, 1994).

Outros resultados de variação das propriedades de deformabilidade são mostrados na Figura 5.51. Estes resultados são apresentados como módulo de cisalhamento e amortecimento normalizados. Os resultados são de corpos de prova ensaiados na umidade ótima $\left(u_{a}-u_{w}\right.$ inicial $=7 \mathrm{kPa}$ ) e tensões confinantes variadas. Na Figura 5.51 (a), encontra-se uma janela com a 
ampliação do eixo vertical, para uma melhor visualização do efeito de $\sigma_{3}$ sobre $G / G_{m a ́ x}$. Os modelos apresentados nas Eq. 5.8 e 5.10 foram usados para ajustar os dados experimentais, e a Tabela 5.15 apresenta os parâmetros obtidos. Elevados coeficientes de determinação foram obtidos para todo o conjunto de resultados de degradação do módulo de cisalhamento e para as duas menores tensões confinantes do conjunto de degradação da razão de amortecimento. As demais tensões confinantes ( $\sigma_{3}$ de 300 e $500 \mathrm{kPa}$ ) mostraram uma dispersão relativamente elevada, considerando o intervalo de $D / D_{\min }$ obtido, o que forneceu menores $r^{2}$.

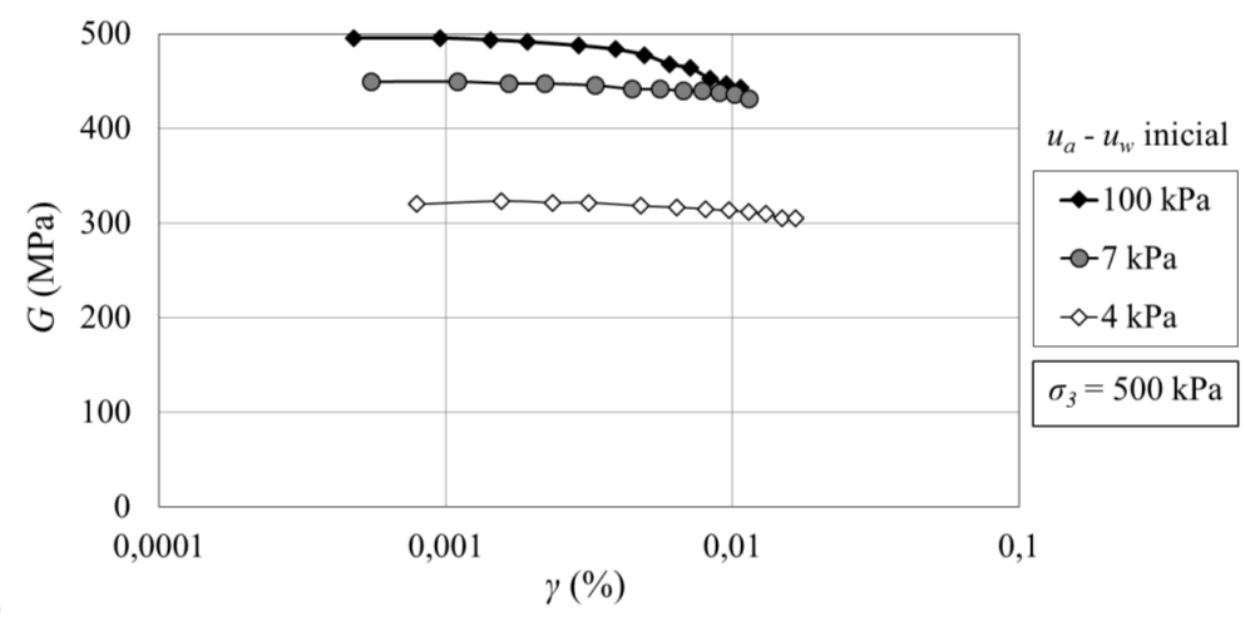

(a)

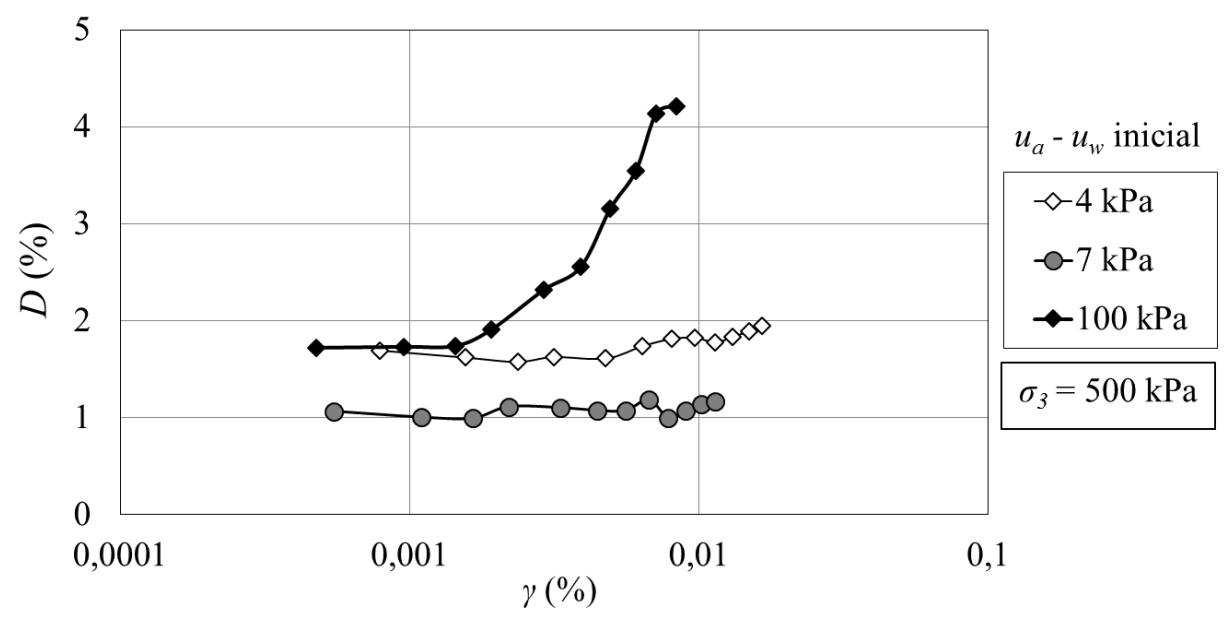

Figura 5.50. (a) Curvas de degradação do módulo de cisalhamento e (b) da razão de amortecimento dos ensaios de coluna ressonante com teor de umidade constante.

Na Figura 5.51 (a), as deformações cisalhantes no limiar do trecho elástico variaram entre $0,0007 \%$, quando $\sigma_{3}$ foi de $10 \mathrm{kPa}$, a $0,0036 \%$, quando $\sigma_{3}$ foi de $500 \mathrm{kPa}$. O mínimo $G / G_{\text {máx }}$ obtido neste conjunto de ensaios foi de 0,70 , que corresponde ao corpo de prova com menor confinamento. Isso ocorre porque um mesmo carregamento torcional provoca maiores 
deformações em materiais mais deformáveis. A degradação do módulo na Figura 5.51 (a), mostra-se inferior à obtida por Barros et al. (1991) em ensaios com amostra indeformada coletada no mesmo município. Esta diferença na degradação do módulo pode ser atribuída ao efeito da compactação e consequente densificação do solo. No que se refere à Figura 5.51 (b), a degradação do amortecimento não apresentou variação significativa para as diferentes tensões confinantes.

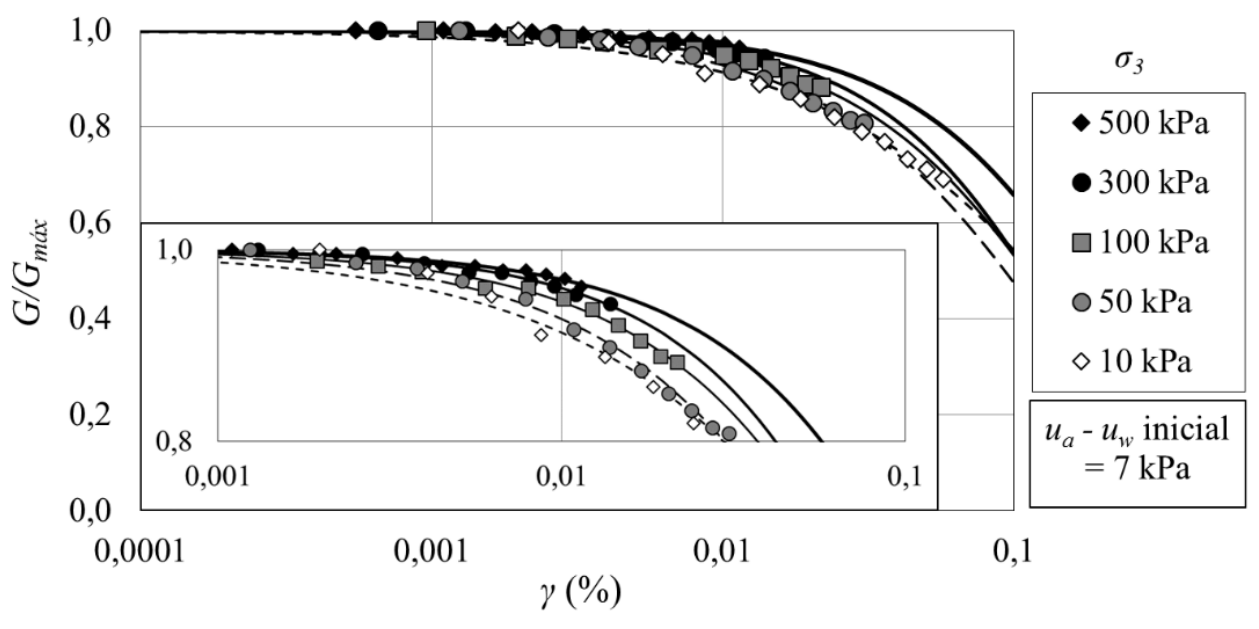

(a)

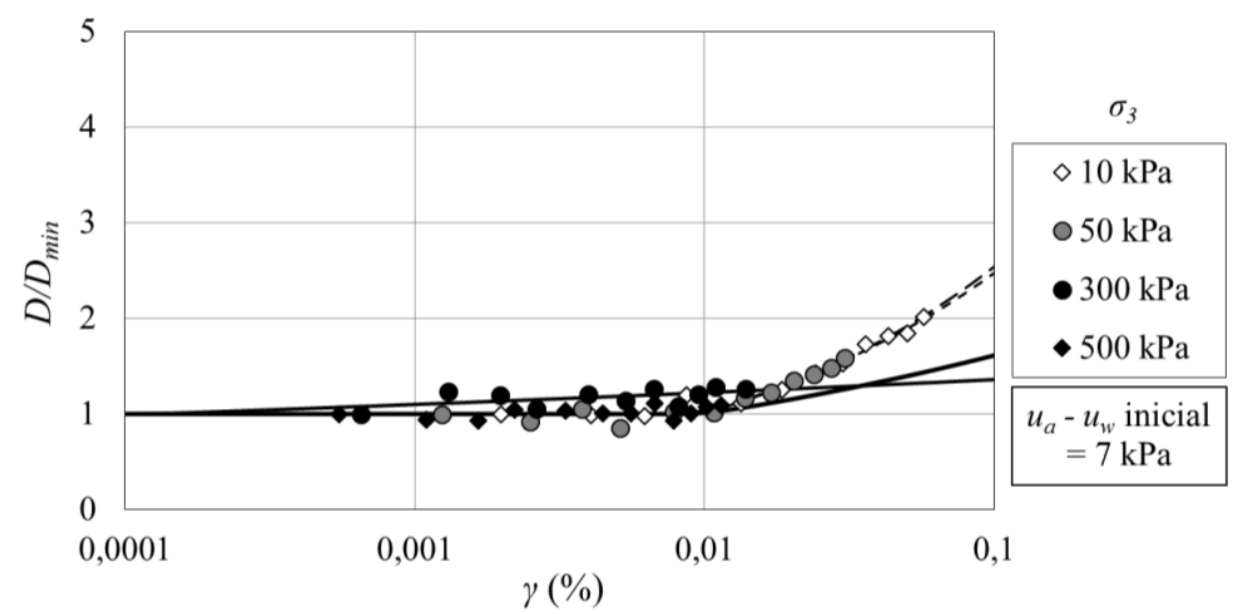

(b)

Figura 5.51. Curvas de (a) degradação do módulo de cisalhamento e (b) da razão de amortecimento normalizados dos ensaios de coluna ressoante com teor de umidade constante.

Em uma análise geral da variação da deformabilidade do solo não saturado com a deformação, foi observado nestes resultados que a tensão confinante e a sucção tiveram mais influência sobre as curvas de $G / G_{\text {máx }}$ do que de $D / D_{\min }$. Além disso, os efeitos da mudança no confinamento foram mais evidentes nas deformações cisalhantes limites e nas curvas como um todo, do que os efeitos de mudanças na sucção do solo, o que pode estar associado à faixa mais 
ampla de tensões confinantes utilizada em relação às sucções. Em geral, as deformações no limiar elástico foram cerca de $0,001 \%$, com os menores valores obtidos a partir dos ensaios de coluna ressonante com sucção constante.

Tabela 5.15. Parâmetros de ajuste das curvas $G / G_{\operatorname{máx}}$ e $D / D_{\min } v s \gamma$ dos ensaios de coluna ressonante com teor de umidade constante (Eq. 5.8 e 5.10).

\begin{tabular}{|c|c|c|c|c|c|c|}
\hline Curva & $u_{a}-u_{w}(\mathrm{kPa})$ & $\sigma_{3}(\mathrm{kPa})$ & $\eta_{1}$ & $\eta_{2}$ & $\eta_{3}$ & $r^{2}$ \\
\hline \multirow{5}{*}{$G / G_{\max } v s \gamma$} & 7 & 10 & 12,91 & 0,84 & 15,48 & 0,99 \\
\hline & 7 & 50 & 25,79 & 1,00 & 30,06 & 0,99 \\
\hline & 7 & 100 & 28,03 & 1,06 & 33,44 & 0,99 \\
\hline & 7 & 300 & 43,65 & 1,19 & 52,21 & 0,99 \\
\hline & 7 & 500 & 28,79 & 1,12 & 34,48 & 0,97 \\
\hline \multirow{5}{*}{$D / D_{\min } v s \gamma$} & & & $\mu_{1}$ & $\mu_{2}$ & $\mu_{3}$ & \\
\hline & 7 & 10 & $3,50.10^{37}$ & 9,35 & 0,04 & 0,97 \\
\hline & 7 & 50 & $3,14.10^{41}$ & 10,38 & 0,04 & 0,95 \\
\hline & 7 & 300 & $3,09.10^{41}$ & 7,03 & 0,01 & 0,30 \\
\hline & 7 & 500 & $3,17.10^{41}$ & 10,37 & 0,02 & 0,26 \\
\hline
\end{tabular}

Considerando a elevada rigidez do solo estudado em relação aos limites de carregamento dos equipamentos de ensaio, as deformações cisalhantes induzidas nestes ensaios não permitiram uma avaliação completa das características de amortecimento do solo. Com isso, não foi possível verificar nesta pesquisa como a tensão confinante e a sucção afetam essa propriedade dinâmica.

\subsubsection{Comparação entre técnicas de ensaio}

Uma breve comparação dos resultados das diferentes técnicas utilizadas para a análise da deformabilidade do solo não saturado é apresentada neste tópico. Tal comparação tem a finalidade de validar os resultados dos ensaios com bender elements, já que esta técnica foi introduzida ao Laboratório de Mecânica dos Solos da Escola de Engenharia de São Carlos por esta pesquisa.

Velocidades das ondas de cisalhamento determinadas por bender elements e ensaios de coluna ressonante com sucção constante (CS) e teor de umidade constante (CW) foram reunidos 
na Figura 5.52. Esta figura mostra resultados de $V_{s}$ contra sucção para tensões confinantes de 50 e $500 \mathrm{kPa}$, onde se pode observar uma razoável correspondência entre os dados.

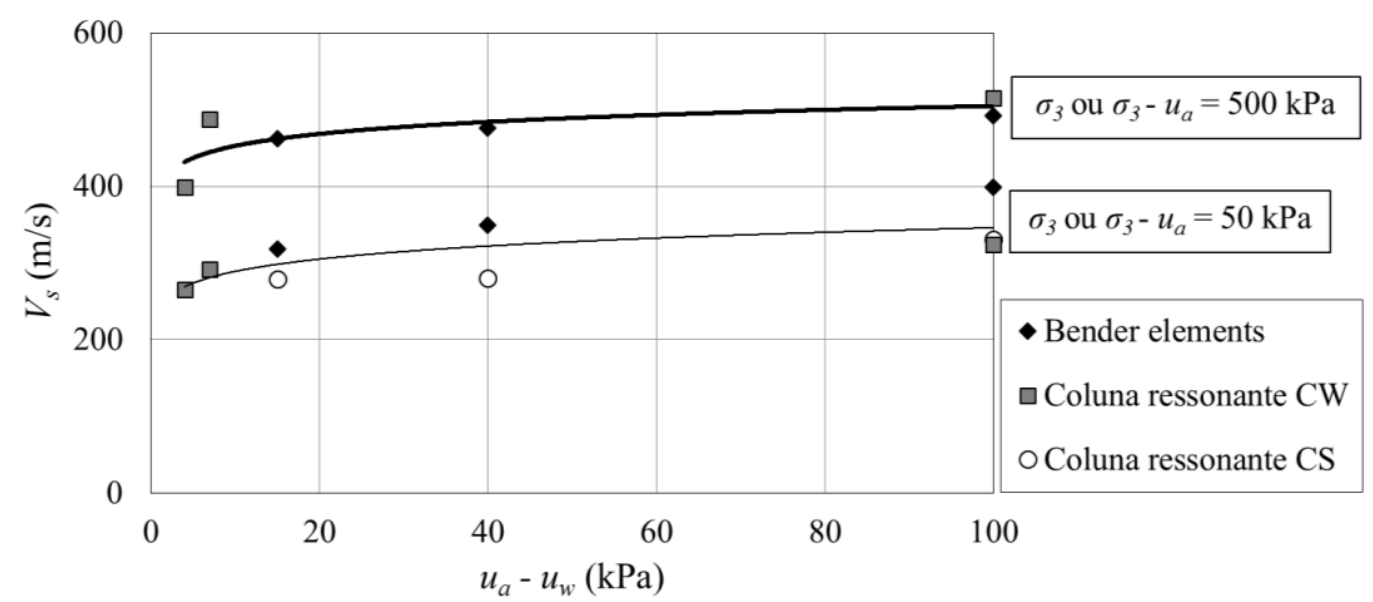

Figura 5.52. Comparação entre velocidades de ondas de cisalhamento obtidas por diferentes técnicas.

Especificamente quando se comparam os resultados dos ensaios drenados, os bender elements forneceram velocidades que foram de 14 a $25 \%$ maiores do que aquelas fornecidas pela coluna ressonante CS. Tendência similar foi observada por outros autores, como Brignoli et al. (1996) e Youn et al. (2008). A diferença entre essas medidas tem sido atribuída à dependência da velocidade da onda de cisalhamento com relação à frequência de ensaio, com frequências mais elevadas induzindo velocidades maiores. De fato, as frequências usadas nos ensaios com bender elements foram da ordem de $10^{4} \mathrm{~Hz}$, enquanto nos ensaios de coluna ressonante as frequências foram da ordem de $10^{2} \mathrm{~Hz}$. No entanto, a influência da frequência de ensaio sobre a velocidade de cisalhamento é um tópico que necessita de estudos mais aprofundados.

Os resultados dos ensaios de coluna ressonante CW estão relativamente de acordo com os resultados dos ensaios drenados. Isso sugere que, quando condições drenadas prevalecem em campo, os erros advindos da estimativa da velocidade da onda de cisalhamento por esta técnica não sejam significativos. 


\section{CONCLUSÕES E SUGESTÕES PARA INVESTIGAÇÕES FUTURAS}

\subsection{CONCLUSÕES}

Esta tese apresentou resultados de uma pesquisa que teve por objetivo principal a análise da deformabilidade de um solo de caráter laterítico típico do interior do Estado de São Paulo. Para isto foi realizada uma ampla investigação do módulo de cisalhamento máximo do solo por meio de ensaios com bender elements tanto em solo saturado como não saturado, compactado e indeformado, que mostraram a influência do teor de umidade de compactação, da tensão de confinamento e da sucção sobre esta propriedade. Adicionalmente, foram realizados ensaios de coluna ressonante e de compressão triaxial em solo compactado na análise das características deformacionais do solo em estudo. A resistência ao cisalhamento do solo também foi medida em caráter complementar, buscando-se uma melhor caracterização mecânica do solo não saturado.

A caracterização do solo foi feita por ensaios convencionais, como análise granulométrica, massa específica dos sólidos e limites de consistência. O solo foi classificado como areia argilosa, SC, pela Classificação Unificada dos Solos e como laterítico arenoso, LA', pela classificação MCT. A compactação na energia Proctor normal, forneceu parâmetros para a preparação de corpos de prova compactados para os demais ensaios, que sempre tiveram grau de compactação de $95 \%$ e teores de umidade variaram entre ( $\left.w_{o t}-2,6 \%\right)$ e $\left(w_{o t}+5,1 \%\right)$. Curvas de retenção de água mostraram como a sucção do solo se relaciona com o grau de saturação, de onde se notaram baixas sucções de entrada de ar e comportamento bimodal para ambas as amostras compactada e indeformada. Resultados de ensaios de porosimetria por intrusão de mercúrio confirmaram a distribuição bimodal de poros do solo em macro e microporos, que influenciam no formato das curvas de retenção.

Ensaios de compressão triaxial dos tipos adensado-drenado e adensado-não drenado foram realizados para se obter envoltórias de resistência ao cisalhamento do solo saturado. Os dados de tensão-deformação, deformação volumétrica e pressão na água mostraram-se coerentes com as teorias de Mecânica dos Solos, e as envoltórias lineares forneceram ângulo de atrito efetivo de $32^{\circ}$ e coesões efetivas nula e de $7 \mathrm{kPa}$ para as amostras indeformada e compactada com teor de umidade ótimo, respectivamente.

Para o solo não saturado, a resistência ao cisalhamento foi avaliada por meio de ensaios com teor de umidade constante em múltiplos estágios, nos quais se aumentou a tensão confinante líquida entre estágios consecutivos. Medidas da variação da pressão na água 
intersticial após cada estágio de adensamento indicaram que maiores variações tendem a ocorrer para maiores tensões confinantes. Além disso, a sucção se alterou mais quando os corpos de prova foram compactados do que quando ensaiados em condição indeformada. Nas fases de cisalhamento com teor de umidade constante, monitoraram-se a sucção e a deformação volumétrica dos corpos de prova, que no geral apresentaram redução de volume e da sucção. Em alguns casos, o solo tendeu à dilatância, com associado aumento da sucção, para a menor tensão de confinamento líquida. Quanto às curvas tensão-deformação, o solo compactado sugeriu a proximidade das resistências máximas para deformações axiais em torno de $5 \%$. $\mathrm{O}$ solo indeformado, entretanto, mostrou encruamento com o acúmulo de deformações plásticas, resultando em crescentes valores de resistência à medida que se avançavam os ensaios até 5\% de deformações axiais. Tal comportamento da amostra indeformada inviabilizou a definição de uma envoltória para a resistência máxima. No entanto, quando se adotou a deformação de 5\% como critério de ruptura, uma envoltória planar compreendendo resultados dos ensaios com solo saturado e não saturado mostrou consistência entre os dados. Já para a amostra compactada no teor de umidade ótimo, definiu-se uma envoltória planar para resistências máximas, obtendose ângulo de atrito de $27^{\circ} \mathrm{com}$ relação à sucção, que está de acordo com dados da literatura. A envoltória definida como um plano mostrou-se representativa no intervalo de tensões e sucções testadas.

Os resultados dos ensaios com bender elements foram interpretados no domínio do tempo com o tempo de percurso da onda de cisalhamento sendo definido como a primeira maior deflexão do sinal recebido. Os tempos de percurso determinados indicaram que a sucção e a tensão confinante contribuíram para a redução da deformabilidade do solo. Este efeito foi observado como sendo mais pronunciado quando a sucção aumentou a partir de zero (saturação) até $15 \mathrm{kPa}$. Na mesma faixa de sucção, a curva de retenção de água no solo mostrou rápida dessaturação, o que era esperado devido à natureza arenosa do solo e sua distribuição de tamanho de poros. As velocidades das ondas de cisalhamento $\left(V_{s}\right)$ foram calculadas a partir de dados com a relação entre a distância percorrida e o comprimento da onda maiores do que 3,0.

Módulos de cisalhamento máximos $\left(G_{m a ́ x}\right)$ em torno de 50 até próximos de $500 \mathrm{MPa}$ foram medidos nos ensaios com bender elements, sendo que para um mesmo valor de confinamento e sucção, o solo indeformado mostrou maior deformabilidade. Os módulos $G_{m a ́ x}$ apresentaram dependência não-linear com relação à tensão confinante, que foi retratada por ajustes potenciais aos resultados experimentais. O efeito do confinamento sobre a deformabilidade do solo reflete a influência do índice de vazios inicial do solo e suas variações com a trajetória de carregamento. Da análise da influência do teor de umidade de compactação 
sobre a deformabilidade do solo saturado, constatou-se que para uma mesma tensão confinante, $G_{m a ́ x}$ foi mais alto para os corpos de prova com menores teores de umidade de moldagem, como esperado. Já para o solo não saturado, observou-se a tendência geral de aumento de $G_{\text {máx }}$ com a sucção. Enquanto para o solo indeformado as sucções ensaiadas não mostraram significativo efeito sobre o módulo, uma função hiperbólica forneceu boa representação da variação desta propriedade com a sucção para o solo compactado com teor de umidade ótimo. Uma representação do conjunto de resultados dos ensaios com bender elements na qual o módulo de cisalhamento e a sucção foram normalizados em relação à tensão confinante, permitiu retratar por uma única relação a variação do módulo de cisalhamento com a sucção e o confinamento para cada condição de moldagem das amostras. Em termos gerais, as tendências de variação apresentadas por $V_{s}$ e $G_{m a ́ x}$ são coerentes com dados de solos arenosos relatados na literatura, enquanto suas magnitudes são semelhantes às obtidas para solos lateríticos brasileiros.

Os ensaios triaxiais com instrumentação interna permitiram observar em solo compactado saturado que o módulo de cisalhamento secante se degrada rapidamente para deformações de até $0,1 \%$ e tende a um valor mínimo após isso, independentemente da tensão de confinamento. Verificou-se também uma suave transição entre os resultados de bender elements e de compressão triaxial quando colocados em conjunto, permitindo avaliar a degradação do módulo com a deformação.

A evolução da deformabilidade do solo não saturado com a deformação cisalhante foi obtida em ensaios de coluna ressonante, os quais forneceram dados de módulo de cisalhamento $(G)$ e razão de amortecimento $(D)$ para o solo compactado não saturado. Os valores da razão de amortecimento mínimo $\left(D_{\text {mín }}\right)$ medidos nestes ensaios variaram entre 1 e $4 \%$. A representação destas propriedades na forma normalizada permitiu constatar que os efeitos de mudanças na sucção e na tensão confinante foram mais pronunciados nas curvas de $G / G_{\text {máx }}$ do que $D / D_{\text {mín }}$. As deformações cisalhantes no limiar elástico pareceram ser mais influenciadas pela tensão confinante do que pela sucção, e foram da ordem de $0,001 \%$.

Por fim, uma comparação entre as velocidades de ondas de cisalhamento obtidas a partir de bender elements e ensaios de coluna ressonante apresentaram resultados razoavelmente próximos, com valores um pouco maiores para os resultados de bender elements. Uma possível razão para essa diferença pode estar relacionada com as frequências de ensaio mais elevadas que foram utilizadas nos ensaios com bender elements, como indicam análises apresentadas por Brignoli et al. (1996) e Youn et al. (2008). Resultados dos ensaios drenados e não drenados não apresentaram significativas diferenças quando comparados. 


\subsection{RECOMENDAÇÕES PARA FUTURAS PESQUISAS}

Apresentam-se a seguir sugestões de tópicos para pesquisa que visam complementar o estudo da deformabilidade do solo usado nesta pesquisa de doutorado, bem como explorar o potencial dos equipamentos recentemente adquiridos pelo Laboratório de Mecânica dos Solos da EESC/USP.

- No que se refere à resistência ao cisalhamento, sugere-se o uso de corpos de prova de maiores dimensões nos ensaios de compressão triaxial utilizando a câmara de parede dupla, além do máximo controle possível da temperatura ambiente, a fim de se reduzir o efeito de alterações de temperatura nas leituras de variação de volume total dos corpos de prova. Isso principalmente nos ensaios com solo não saturado, quando as variações de volume do solo são menores.

- Seria também interessante o uso de bender elements em ensaios de compressão triaxial para se obter variações da velocidade da onda de cisalhamento no decorrer da fase de cisalhamento em diferentes níveis de deformação.

- Os ensaios de compressão triaxial com instrumentação interna podem ser usados na avaliação da deformabilidade do solo não saturado, e os resultados podem ser comparados com os de solo saturado apresentados nesta tese.

- Com relação aos ensaios com bender elements em compressão isotrópica, mais dados são necessários para se avaliar a influência da sucção sobre o módulo de cisalhamento máximo em amostra indeformada.

- Na tentativa de avaliar o método de determinação do tempo de percurso da onda de cisalhamento, sugere-se a aplicação de outras metodologias no domínio do tempo e da frequência, além do método utilizado nesta pesquisa, e a comparação de resultados.

- A técnica de bender elements pode ainda ser explorada no estudo da relação entre a velocidade da onda de compressão (tipo P) e o grau de saturação do solo, e na medida de amortecimento através de ondas de cisalhamento.

- Outros tópicos para estudo da deformabilidade neste solo seriam o efeito da histerese, a partir da preparação de amostras em trajetórias de secagem e umedecimento, e o efeito de anisotropia tanto em amostra compactada quanto indeformada. 


\section{REFERÊNCIAS BIBLIOGRÁFICAS}

Abramento, M.; Carvalho, C.S. Geotechnical parameters for study of natural slopes instabilization at Serra do Mar, Brazil. In: International Conference on Soil Mechanics and Foundation Engineering, 12., 1989, Rio de Janeiro. Proceedings... Rotterdam: Balkema, 1989. v. 2, p. 1599-1602.

Aitchison, G. D. Engineering concepts of moisture changes in soils - Statement of the review panel. In: Moisture Equilibria and Moisture Changes in the Soils beneath Covered Areas, 1965. Proceedings...Sydney: Butterworths, 1965. p.7-21.

ASTM a. Standard test method for measurement of soil potential (suction) using filter paper D5298. In: Annual Book of ASTM Standards. West Conshohocken, Pa: American Society for Testing Materials, 2010a. v. 04.08.

ASTM b. Standard test methods for modulus and damping of soils by resonant-column method - D4015. In: Annual Book of ASTM Standards. West Conshohocken, Pa: American Society for Testing Materials, 2007. v. 04.08.

ASTM. Standard test method for determination of pore volume and pore volume distribution of soil and rock by mercury intrusion porosimetry - D4404. In: Annual Book of ASTM Standards. West Conshohocken, Pa: American Society for Testing Materials, 2010b. v. 04.08.

Atkinson, J. H. Non-linear soil stiffness in routine design. Géotechnique, v. 50, n. 5, p. 487$508,2000$.

Atkinson, J. H.; Sällfors, G. Experimental-determination of stress-strain-time characteristics in laboratory and in situ tests. In: Deformation of Soils and Displacements of Structures: $10^{\text {th }}$ European Conference on Soil Mechanics and Foundation Engineering. Proceedings... Florence: A A Balkema, 1991. v. 3, p. 915-956.

Barros, J. M. C. Módulo de cisalhamento dinâmico de solos tropicais. 1997. 437 p. Tese (doutorado) - Escola Politécnica, Universidade de São Paulo, São Paulo, 1997.

Barros, J. M. C.; Giacheti, H. L.; Martins, M. C. R. Dynamic properties of some Brazilian lateritic soils. In: IX Panamerican Conference on Soil Mechanics and Foundation Engineering, 1991, Vinã del Mar, Chile. Proceedings... Sociedad Chilena de Geotecnia, 1991. v. 1. p. 1517.

Barros, J. M. C.; Hachich, W. Fundações sujeitas a esforços dinâmicos. In: Hachich, W.; Falconi, F. F.; Saes, J. L.; Frota, R. G. Q.; Carvalho, C. S.; Niyama, S. Fundações: teoria e prática. 2ed. São Paulo: PINI, 1998. cap. 10, p. 409-442.

Bishop, A. W. The principle of effective stress. Teknisk Ukeblad, 1959. v. 106, n. 39, p. 859863.

Bishop, A. W.; Alpan, J.; Blight, G. E.; Donald, I. B. Factors controlling the strength of partly saturated cohesive soils. In: Research Conference Shear Strength of Cohesive Soils, 1960, 
Boulder. Proceedings... New York: American Society of Civil Engineers (ASCE), 1960. p. 503-532.

Bishop, A. W.; Donald, I. B. The experimental study of partly saturated soil in the triaxial apparatus. In: International Conference on Soil Mechanics and Foundation Engineering, 5., 1961, Paris. Proceedings... Paris: Dunod, 1961. v. 1, p. 13-21.

Bocking, K. A.; Fredlund, D. G. Limitations of the axis translation technique. In: Fourth International Conference on Expansive Soils. Proceedings... New York: American Society of Civil Engineers (ASCE), 1980. p. 117-135.

Borden, R. H.; Shao, L.; Gupta, A. Dynamic properties of Piedmont residual soils. Journal of Geotechnical Engineering, v. 122, n. 10, p. 813-821, 1996.

Brignoli, E. G. M.; Gotti, M.; Stokoe, K. H., II. Measurement of shear waves in laboratory specimens by means of piezoelectric transducers. Geotechnical Testing Journal, v. 19, n. 4, p. 384-397, 1996.

Brocanelli, D.; Rinaldi, V. Measurement of low-strain material damping and wave velocity with bender elements in the frequency domain. Canadian Geotechnical Journal, v. 35, n. 6, p. 1032-1040, 1998.

Burland, J. B. Ninth Laurits Bjerrum Memorial Lecture: Small is beautiful - the stiffness of soils at small strains. Canadian Geotechnical Journal, v. 26, n. 4, p. 499-516, 1989.

Calle, J. A. C. Análise de ruptura de talude em solo não saturado. 2000. 128f. Dissertação - Geotecnia, Escola de Engenharia de São Carlos, Universidade de São Paulo, São Carlos, 2000 .

Carrillo, C. W. Resistência ao cisalhamento dos solos coluvionares e residuais não saturados da Vista Chinesa, RJ. 1993. 159 p. Dissertação (Mestrado) - Departamento de Engenharia Civil, Pontifícia Universidade Católica, Rio de Janeiro, 1993.

Chan, C.-M. Bender element test in soil specimens: identifying the shear wave arrival time. Electronic Journal of Geotechnical Engineering, v. 15M, p. 1263-1275, 2010.

Chandler, R.J.; Crilly, M.S.; Montgomery-Smith, G. A low-cost method of assessing clay desiccation for low-rise buildings. Proceeding of the Institution of Civil Engineering, v. 92, n. 2, p. 82-89, 1992.

de Campos, T. M. P. Resistência ao cisalhamento de solos não saturados. In: Simpósio Brasileiro de Solos Não Saturados, 3., 1997, Rio de Janeiro. Anais... Rio de Janeiro: Freitas Bastos, 1997. v.2, p.399-417.

Donald, I. B. Discussion. In: Conference on Pore Pressure and Suction in Soils, 1960, London. Proceedings... London: Butterworths, 1961.

Dyvik, R.; Madshus, C. Lab measurements of $\mathrm{G}_{\max }$ using bender element. Advances in the Art of Testing Soils under Cyclic Conditions. Proceedings... New York: ASCE. 1985. p.186-196.

Escario, V.; Sáez, J. The shear strength of partly saturated soils. Geotechnique, v. 36, n. 3, p. 453-456, 1986. 
Ewins, D. J. Modal testing: theory and practice. Letchworth: Research Studies Press Ltd., $1984,282 \mathrm{p}$.

Fernandes, M. A. Condutividade hidráulica não saturada de um solo arenoso: aplicação do infiltrômetro de disco. 2011. 159p. Dissertação (Mestrado) - Escola de Engenharia de São Carlos, Universidade de São Paulo, São Carlos, 2011.

Feuerharmel, C. Aspectos do comportamento não saturado de dois solos coluvionares Gasoduto Bolívia-Brasil. 2003. 148f. Dissertação (Mestrado) - Universidade Federal do Rio Grande do Sul, Porto Alegre, 2003.

Fioravante, V.; Capoferri, R. On the use of multi-directional piezoelectric transducers in triaxial testing. Geotechnical Testing Journal, v. 24, n. 3, p. 243-255, 2001.

Florez, E. A. S. Development of a suction-controlled resonant column apparatus with selfcontained bender elements. 2010. Master Thesis - University of Texas at Arlington, Arlington, 2010.

Fonseca, E. C. Ensaio de cisalhamento direto com sucção controlada em solos não saturados. 1991. 173 p. Dissertação (Mestrado) - Departamento de Engenharia Civil, Pontifícia Universidade Católica, Rio de Janeiro, 1991.

Fonseca, E. C.; Campos, L. E. P.; Presa, E. P.; Machado, S. L. Ensaios triaxiais de estágios múltiplos com controle de sucção em solos residuais de granulito. In: Simpósio sobre Solos Não Saturados, 2., 1994, Recife. Anais... Recife: Universitária/UFPE, 1994. p.45-51.

Fredlund, D. G.; Morgenstern, N. R. Stress state variables for unsaturated soils. ASCE Journal of the Geotechnical Engineering Division, GT5, v. 103, p. 447-466, 1977.

Fredlund, D. G.; Morgerstern, N. R.; Widger, R. A. The shear strength of unsaturated soils. Canadian Geotechnical Journal, v. 15, n. 3, p. 313-321, 1978.

Fredlund, D. G.; Rahardjo, H. Soil mechanics for unsaturated soils. New York: John Wiley \& Sons, Inc., 1993. 517 p.

Fredlund, D. G.; Rahardjo, H.; Gan, J. K. M. Non-linearity of strength envelope for unsaturated soils. In: $6^{\text {th }}$ International Conference on Expansive Soils, 1987. Proceedings... New Delhi, 1987. v. 1, p. 49-54.

Fredlund, D. G.; Xing, A. Equations for the soil-water characteristic curve. Canadian Geotechnical Journal, v.31, n.3, p.521-532, 1994.

Freitas Neto, O. Resistência ao cisalhamento de um solo não saturado com medida direta de sucção. 2008. 178f. Dissertação (Mestrado) - Escola de Engenharia de São Carlos, Universidade de São Paulo, São Carlos, 2008.

Georgetti, G. B. Resistência de um solo não saturado a partir de ensaios com teor de umidade constante (CW). 2010. 108p. Dissertação (Mestrado) - Escola de Engenharia de São Carlos, Universidade de São Paulo, São Carlos, 2010.

Giacheti, H. L. Estudo experimental de parâmetros dinâmicos de alguns solos tropicais do Estado de São Paulo. 1991. 232 p. Tese (doutorado) - Escola de Engenharia de São Carlos, Universidade de São Paulo, São Carlos, 1991. 
Gui, M.-W.; Yu C.-M. Rate of strength increase of unsaturated lateritic soil. Canadian Geotechnical Journal, v. 45, n. 9, p. 1335-1343, 2008.

Hardin, B. O.; Drnevich, V. P. Shear modulus and damping in soils: measurements and parameters effects. Journal of the Soil Mechanics and Foundation Division, ASCE, v. 98, n. 6, p. 603-624, 1972.

Head, K. H. Manual of soil laboratory testing: Volume 3 - Effective stress tests. London: Pentech Press Limited, 1986. 1238p.

Hilf, J. W. An investigation of pore-water pressure in compacted cohesive soils. 1956. 109 f. PhD Thesis - Faculty of Graduate School, University of Colorado, Denver, 1956.

Hillel, D. Physical principles. In: New York: Academic Press, 1971. p.5-127.

Soil and water: Physical principles and processes.

Hoyos, L. R.; Puppala, A. J.; Chainuwat, P. Dynamic properties of chemically stabilized sulfate rich clay. Journal of Geotechnical and Geoenvironmental Engineering, v. 130, n. 2, p. 153$162,2004$.

Hu, R.; Chen, Y.-F.; Liu, H.-H.; Zhou, C.-B. A water retention curve and unsaturated hydraulic conductivity model for deformable soils: consideration of the change in pore-size distribution. Géotechnique, v. 63, n. 16, p. 1389-1405, 2013.

Jardine, R. J., Symes, M. J., and Burland, J. B. The measurement of soil stiffness in the triaxial apparatus. Géotechnique, v. 34, n. 3, p. 323-340, 1984.

Jardine, R. J.; Potts, D. M.; Fourie, A. B.; and Burland J. B. Studies of the influence of nonlinear stress-strain characteristics in soil-structure interaction. Géotechnique, v.36, n.3, p. 377396, 1986.

Jennings, J. E. B.; Burland, J. B. Limitations to the use of effective stresses in partly saturated soils. Géotechnique, v. 12, n. 2, p. 125-144, 1962.

Jovičić, V.; Coop, M. R.; Simić, M. Objective criteria for determining $G_{\max }$ form bender element tests. Géotechnique, v. 46, n. 2, p. 357-362, 1996.

Karl, L.; Haegeman, W.; Degrande, G.; Dooms, D. Determination of the material damping ratio with the bender element test. Journal of Geotechnical and Geoenvironmental Engineering, v. 134, n. 12, p. 1743-1756, 2008.

Lee, J.-S.; Santamarina, J.C. Bender elements: performance and signal interpretation. Journal of Geotechnical and Geoenvironmental Engineering, v. 131, n. 9, p. 1063-1070, 2005.

Leong, E. C.; Cahyadi, J.;Rahardjo, H. Stiffness of a compacted residual soil. In: International Conference on Unsaturated Soils, 4., 2006, Carefree. Proceedings... New York: ASCE, 2006. v.1, p.1169-1180.

Leong, E. C.; Rahardjo, H. Review of soil-water characteristic curve equations. Journal of Geotechnical and Geoenvironmental Engineering, v. 123, n. 12, p. 1106-1117, 1997.

Leong, E. C.; Yeo, S. H.; Rahardjo, H. Measuring shear wave velocity using bender elements. Geotechnical Testing Journal, v. 28, n. 5, p. 488-498, 2005. 
Libardi, P. L. Dinâmica da água no solo. Piracicaba: ESALQ/USP - Departamento de Física e Meteorologia, 1995.497p.

Lu, N.; Likos, W. J. Unsaturated soil mechanics. Hoboken: John Wiley \& Sons, Inc., 2004. $556 \mathrm{p}$.

Machado, S. L. Aplicação de conceitos de elastoplasticidade a solos não saturados. 1998. 361f. Tese - Geotecnia, Escola de Engenharia de São Carlos, Universidade de São Paulo, São Carlos, 1998.

Madhusudhan, B. N.; Kumar, J. Damping of sands for varying saturation. Journal of Geotechnical and Geoenvironmental Engineering, v. 139, n. 9, p. 1625-1630, 2013.

Mancuso, C.; Vassallo, R.; d'Onofrio, A. Small strain behavior of a silty sand in controlledsuction resonant column torsional shear tests. Canadian Geotechnical Journal, v. 39, n. 1, p. 22-31, 2002.

Marinho, F. A. M. Medição de sucção com o método do papel filtro. In: X Congresso Brasileiro de Mecânica dos Solos e Engenharia de Fundações. Anais... São Paulo: Associação Brasileira de Mecânica dos Solos (ABMS), 1994. v.2. p.515-522.

Marinho, F. A. M.; Chandler, R.; Crilly, M. Stiffness measurements on an unsaturated high plasticity clay using bender elements. In: $1^{\text {st }}$ International Conference on Unsaturated Soils. Proceedings... Rotterdam: Balkema, 1995. v.2, p.535-539.

Marinho, F. A. M.; Gomes, J. E. S. The effect of contact on the filter paper method for measuring soil suction. Geotechnical Testing Journal, v. 35, n. 1, p. 172-181, 2012.

$\mathrm{Ng}, \mathrm{C} . \mathrm{W}$. W.; Xu, J. Effects of current suction ratio and recent suction history on small-strain behaviour of an unsaturated soil. Canadian Geotechnical Journal, v.49, n.2, p.226-243, 2012.

Nogami, J. S.; Villibor, D. F. Pavimentação de Baixo Custo com Solos Lateríticos. São Paulo: Vilibor, 1995. 240p.

Nogami, J. S.; Villibor, D. F. Soil characterization of mapping units for highway purposes in a tropical area. Bulletin of International Association of Engineering Geology, n.19, p.196199, 1979.

Nyunt, T. T.; Leong, E. C.; Rahardjo, H. Strength and small-strain stiffness characteristics of unsaturated sand. Geotechnical Testing Journal, v.34, n.5, p. 551-561, 2011.

Öberg, A.-L.; Sällfors, G. Determination of shear strength parameters of unsaturated silts and sands based on the water retention curve. Geotechnical Testing Journal, v.20, n.1, p.40-48, 1997.

Oliveira, O. M. Estudo sobre a resistência ao cisalhamento de um solo residual compactado não saturado. 2004. 361f. Tese (Doutorado) - Escola Politécnica, Universidade de São Paulo, São Paulo, 2004.

Patil, U. D.; Puppala, A. J.; Hoyos, L. R. Strength/volume change behaviour of compacte silty sand using a novel double-walled suction-controlled triaxial system. In: International Conference on Unsaturated Soils, 6., 2014, Sydney. Proceedings... London: Taylor \& Francis Group, 2014. v. 2, p. 1727-1733. 
Pennington, D. S.; Nash, D. F. T.; and Lings, M. L. Horizontally mounted bender elements for measuring anisotropic shear moduli in triaxial clay specimens. Geotechnical Testing Journal, v.24, n.2, p. 133-144, 2001.

Power K. C.; Vanapalli S. K.; Garga V. K. A Revised Contact Filter Paper Method. Geotechnical Testing Journal, v. 31, n. 6, p. 581-590, 2008.

Rahardjo, H.; Heng, O. B.; Choon, L. E. Shear strength of a compacted residual soil from consolidated drained and constant water content triaxial tests. Canadian Geotechnical Journal, v.41, p.421-436, 2004.

Richart, F. E.; Hall, J. R.; Woods, R. D. Vibration of soils and foundations. New Jersey: Prentice Hall Inc., 1970, 414 p.

Ridley, A. M.; Burland, J. B. A new instrument for the measurement of soil moisture suction. Géotechnique, v.44, n.2, p.321-324, 1993.

Rocha, B. P. Emprego do ensaio SPT sísmico na investigação de solos tropicais. 2013. 116 p. Dissertação (mestrado) - Escola de Engenharia de São Carlos, Universidade de São Paulo, São Carlos, 2013.

Röhm, S. A. Resistência ao cisalhamento de um solo arenoso laterizado não saturado da região de São Carlos-SP. 1992. 274 f. Tese (doutorado) - Escola de Engenharia de São Carlos, Universidade de São Paulo, São Carlos, 1992.

Röhm, S. A.; Vilar, O.M. Shear strength of an unsaturated sandy soil. In: International Conference on Unsaturated Soils, 1., 1995, Paris. Proceedings... Rotterdam: Balkema, 1995. v.1, p.189-193.

Sanchez-Salinero, I.; Roesset, J.M. \& Stokoe, K.H.II. Analytical Studies of body wave propagation and attenuation. Report No. GR 86-15. Austin: Civil Engineering Department, University of Texas at Austin, 1986.

Seed, H. B.; Idriss, I. M. Soil moduli and damping factors for dynamic response analyses. Report No. EERC 70-10. Earthquake Engineering Research Center, University of California, 1970.

Takkabutr, P. Experimental investigations on small-strain stiffness properties of partially saturated soils via resonant column and bender element testing. 2006. Ph.D. Dissertation University of Texas at Arlington, Arlington, 2006.

Terzaghi, K. The shearing resistance of saturated soils and the angle between the planes of shear. In: International Conference on Soil Mechanics and Foundation Engineering, 1., 1936, Cambridge. Proceedings... Cambridge: Harvard University Printing Office, 1936. v.1, p. 5456.

Valle-Molina, C.; Stokoe, K.H. II. Seismic measurements in sand specimens with varying degrees of saturation using piezoelectric transducers. Canadian Geotechnical Journal, v.49, n.6, p.671-685, 2012.

van Genuchten, M. T. A closed-form equation for predicting the hydraulic conductivity of unsaturated soils. Soil Science Society of America Journal, v. 44, n. 5, p. 892-898, 1980. 
Vanapalli, S. K.; Fredlund, D. G.; Pufahl, D. E.; Clifton, A. W. Model for the prediction of shear strength with respect to soil suction. Canadian Geotechnical Journal, v. 33, p. 379-392, 1996.

Vassallo, R.; Mancuso, C.; Vinale, F. Effects of net stress and suction history on the small strain stiffness of a compacted clayey silt. Canadian Geotechnical Journal, v. 44, n. 4, p. 447-462, 2007.

Viggiani, G.; Atkinson, J. H. Interpretation of bender element tests. Géotechnique, v. 45, n. 1, p. 149-154, 1995.

Vilar, O. M. An expedite method to predict the shear strength of unsaturated soils. Soils and Rocks, v. 30, n. 1, p. 51-61, 2007.

Vilar, O. M.; Rodrigues, R. A. Collapse behavior of soil in a Brazilian region affected by a rising water table. Canadian Geotechnical Journal, v. 48, n. 2, p. 226-233, 2011.

Vucetic, M. Cyclic threshold shear strains in soils. Journal of Geotechnical Engineering, v. 120, n. 12, p. 2208-2228, 1994.

Youn, J. U.; Choo, Y. W.; Kim, D. S. Measurement of small-strain shear modulus $\mathrm{G}_{\max }$ of dry and saturated sands by bender element, resonant column, and torsional shear tests. Canadian Geotechnical Journal, v. 45, n. 10, p. 1426-1438, 2008. 


\section{ANEXO: RESULTADOS DOS ENSAIOS DE COMPRESSÃO TRIAXIAL COM SOLO NÃO SATURADO}

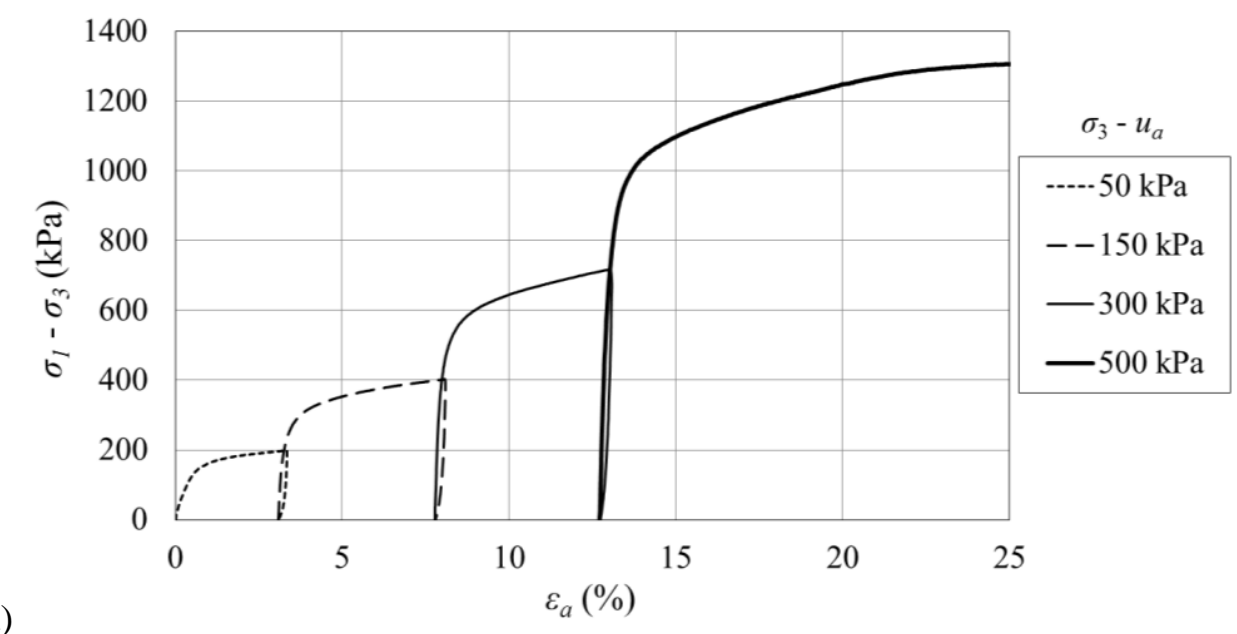

(a)

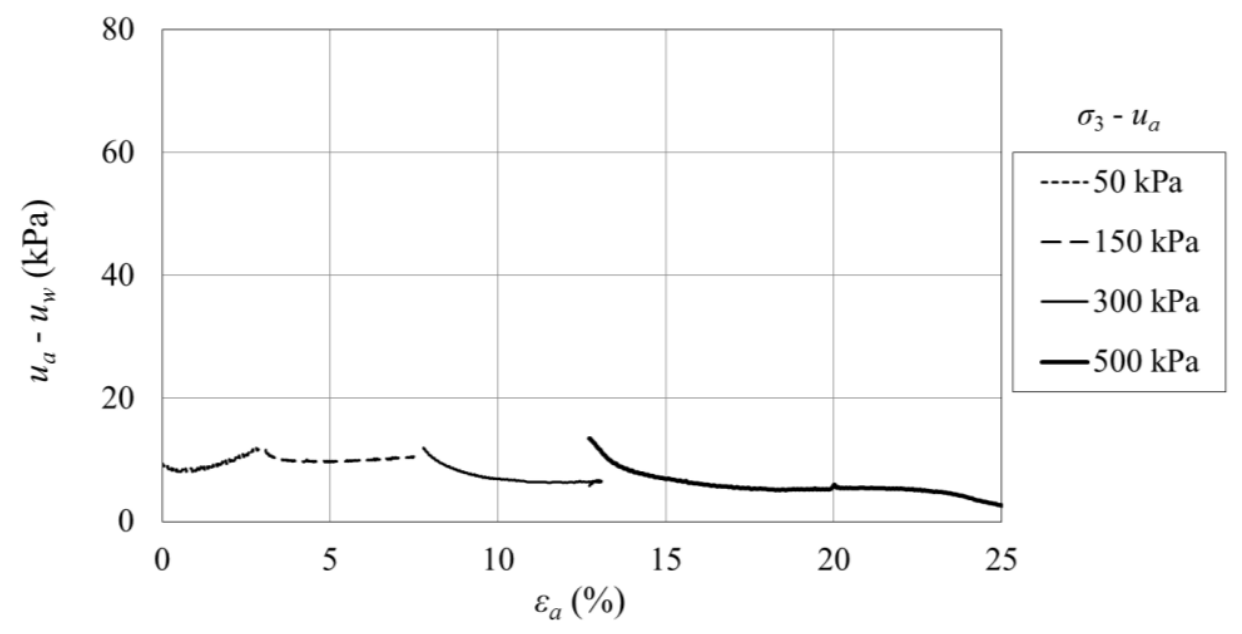

(b)

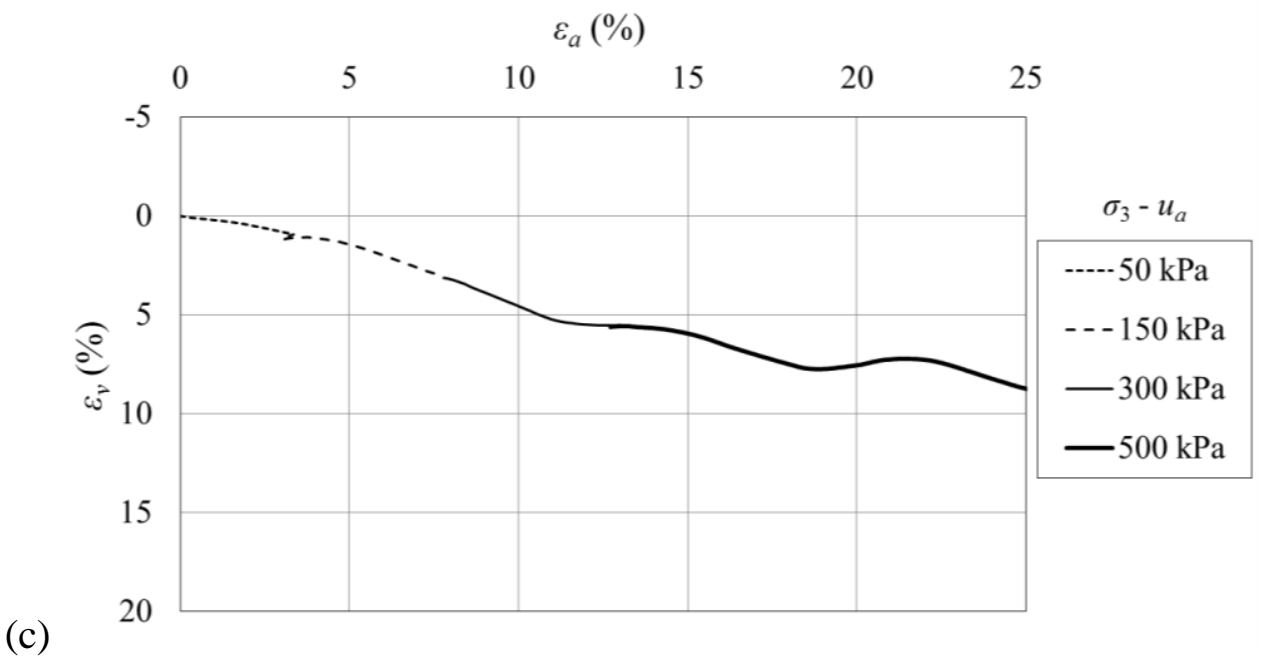

Figura A.1. Curvas (a) tensão-deformação, (b) variação da sucção e (c) deformação volumétrica do ensaio CW com solo compactado e ensaiado com sucção inicial de $15 \mathrm{kPa}$. 


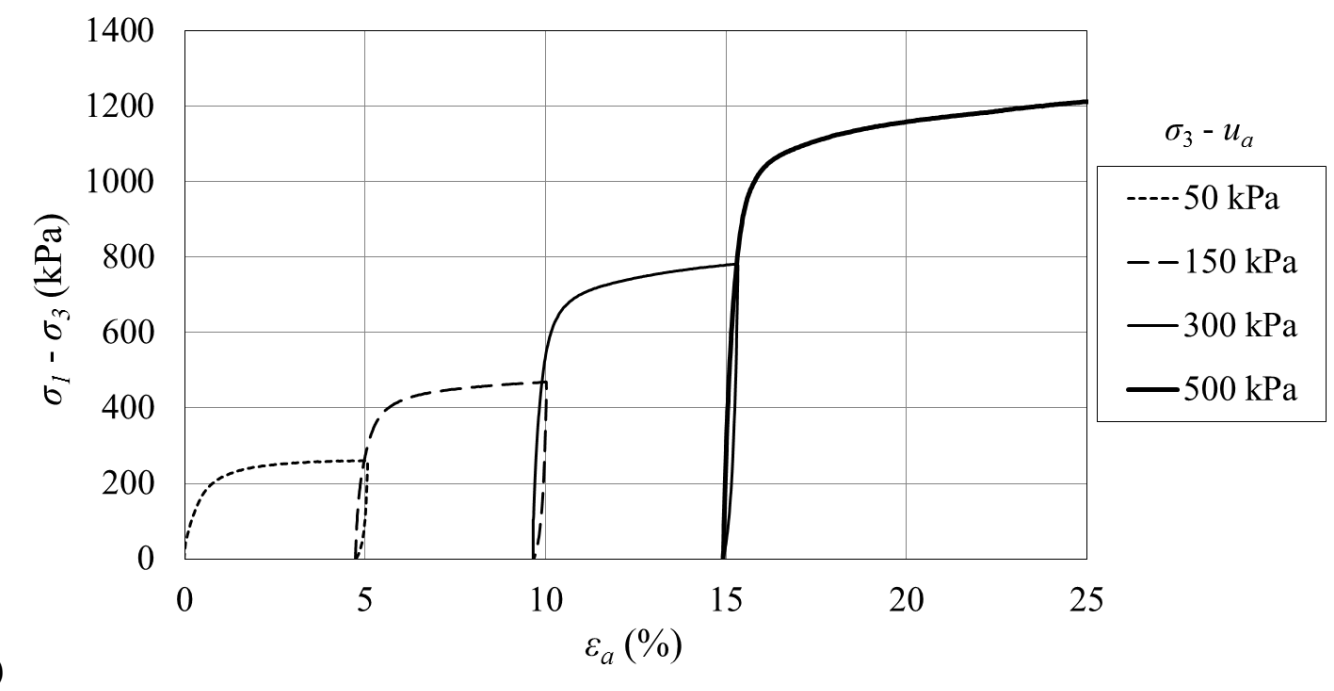

(a)

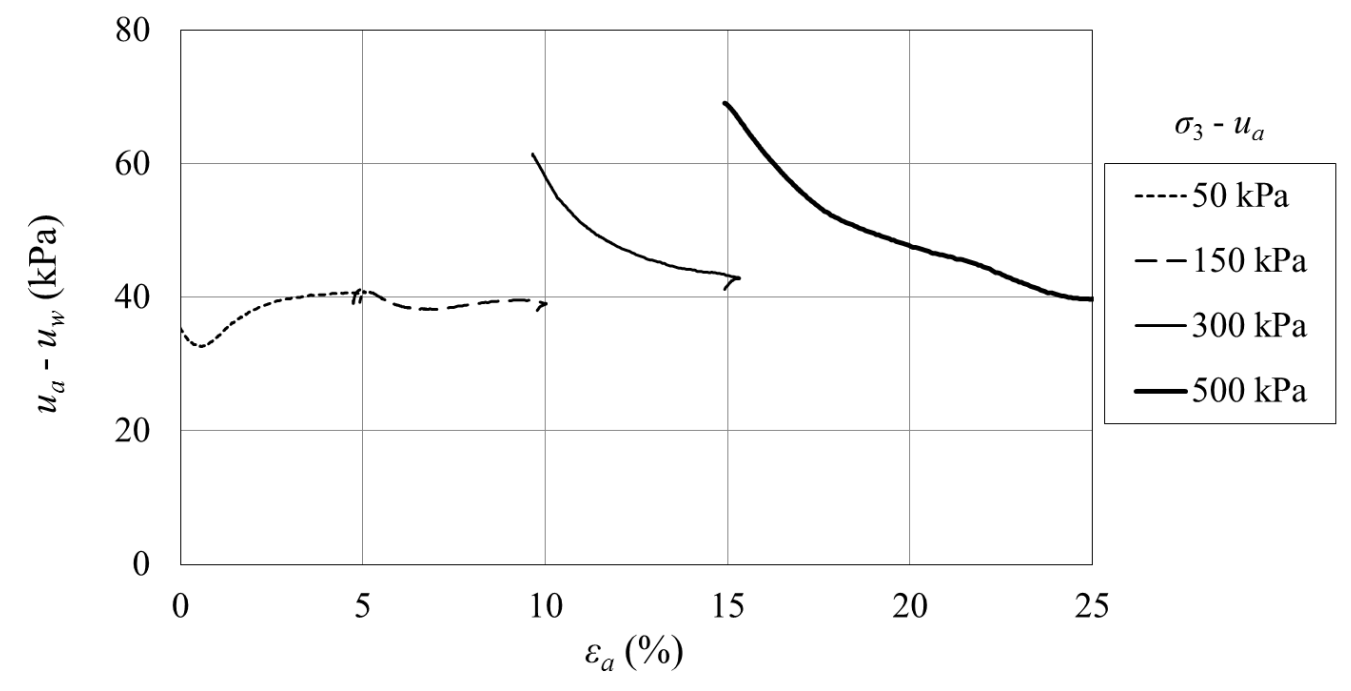

(b)

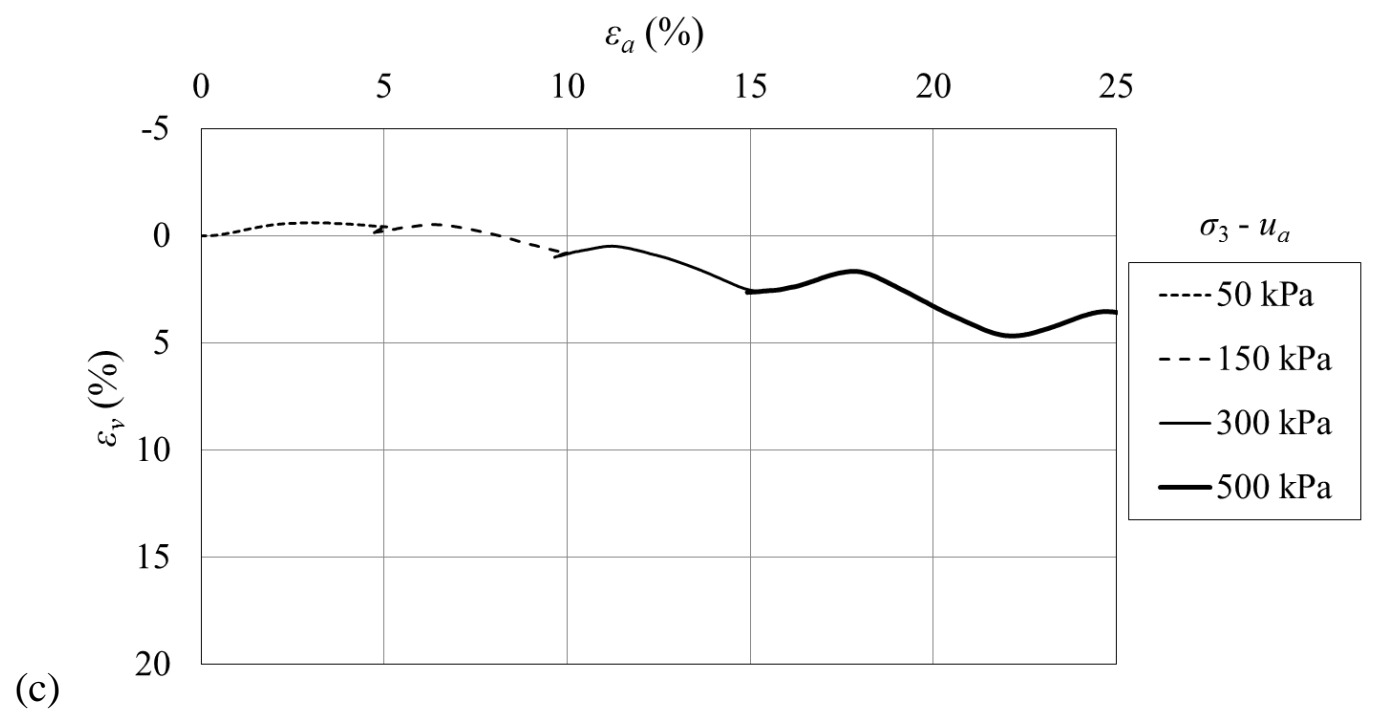

Figura A.2. Curvas (a) tensão-deformação, (b) variação da sucção e (c) deformação volumétrica do ensaio CW com solo compactado e ensaiado com sucção inicial de $100 \mathrm{kPa}$. 


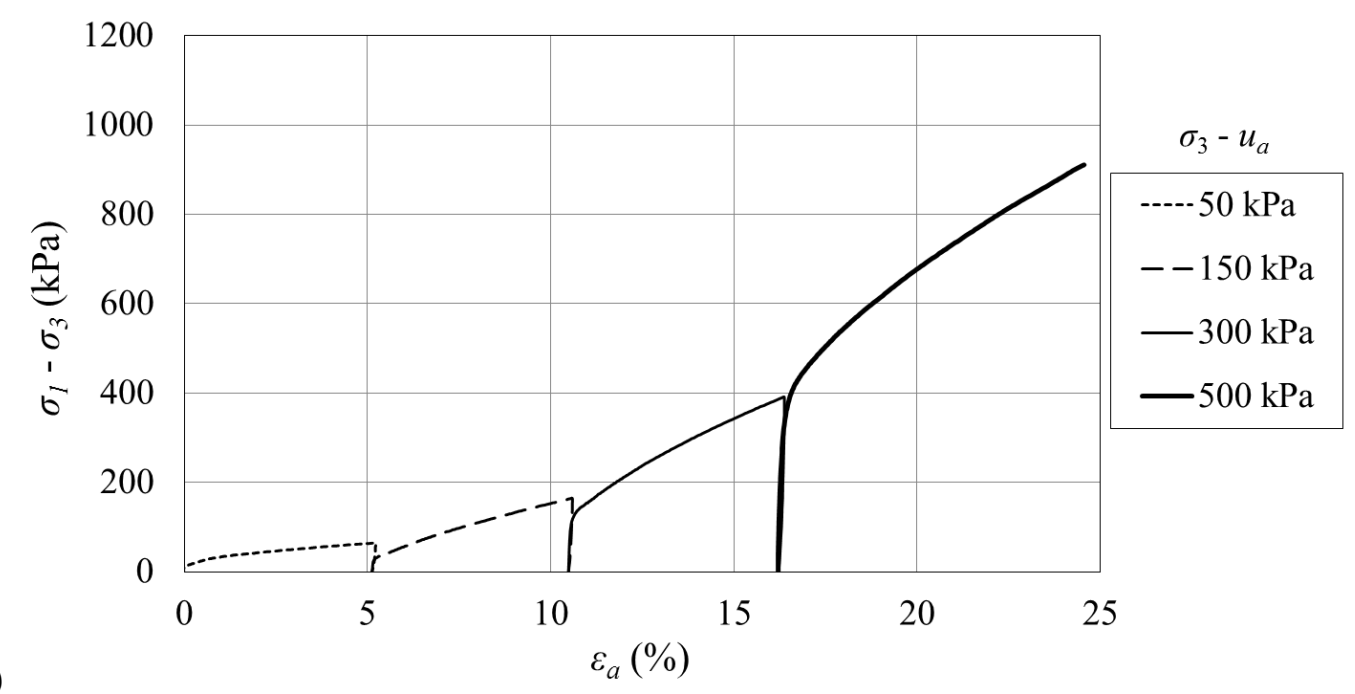

(a)

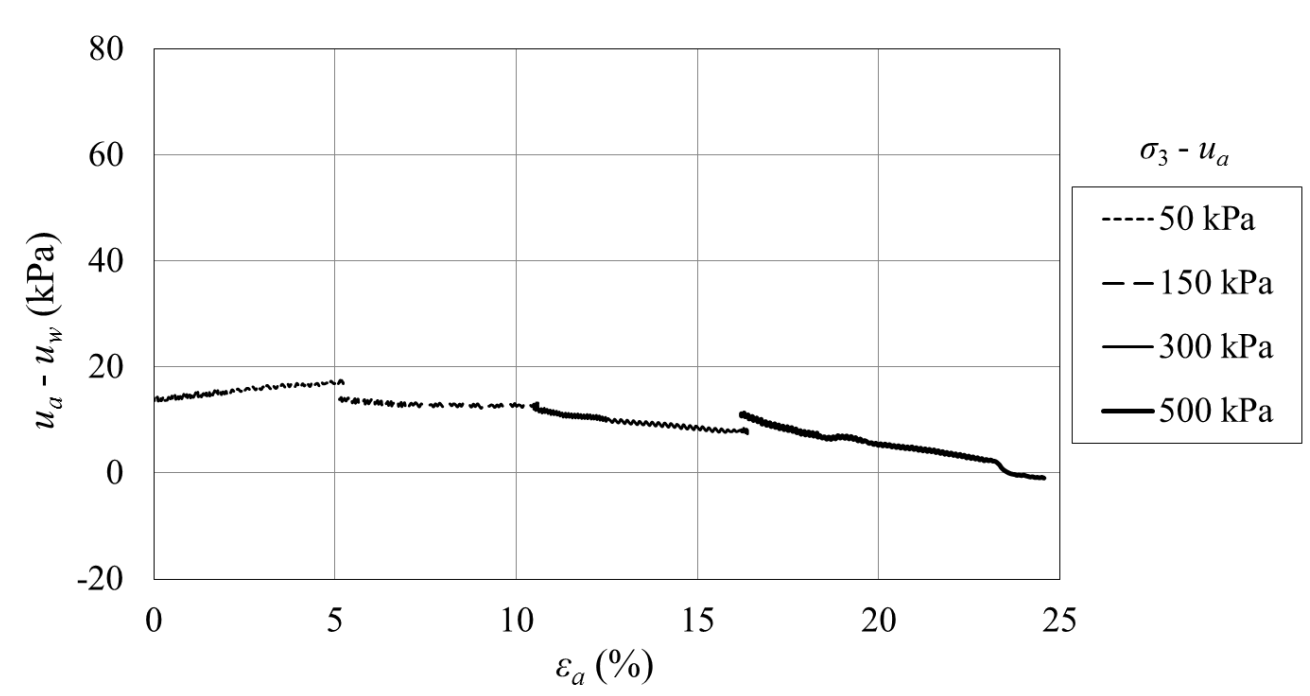

(b)

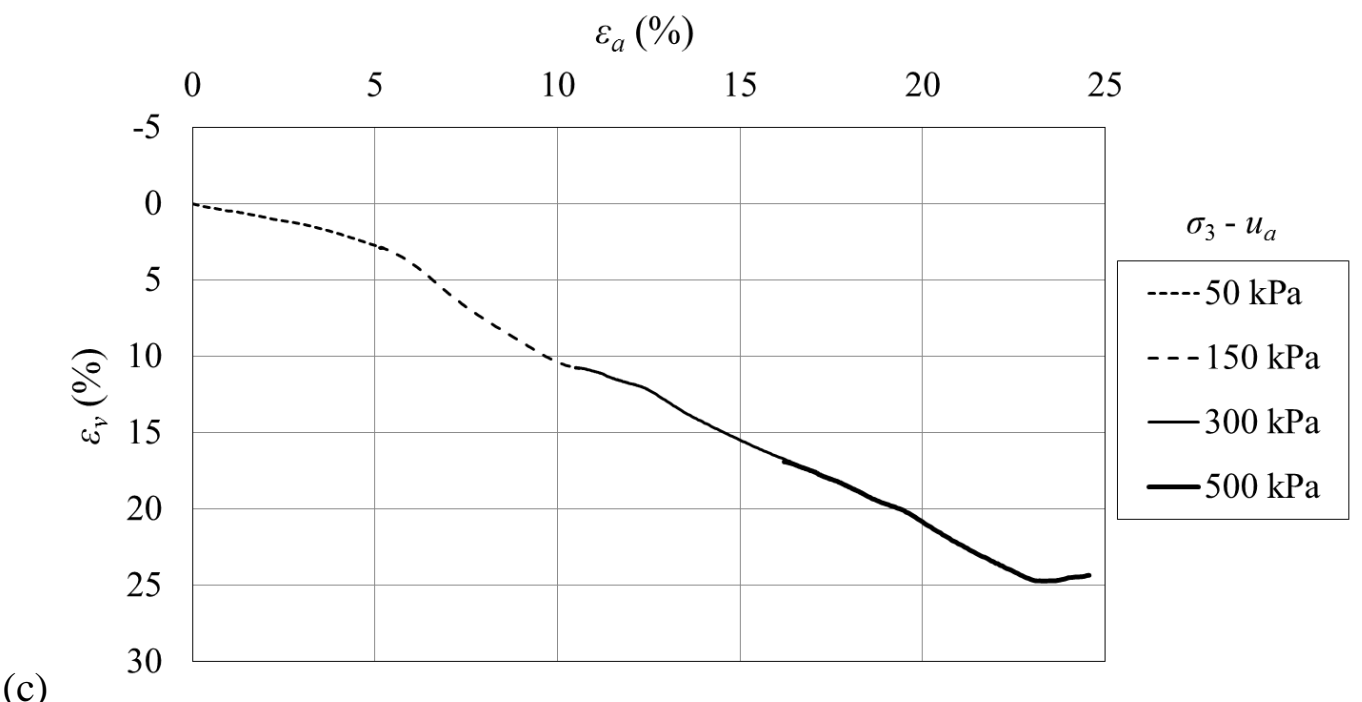

Figura A.3.Curvas (a) tensão-deformação, (b) variação da sucção e (c) deformação volumétrica do ensaio CW com solo indeformado e ensaiado com sucção inicial de $15 \mathrm{kPa}$. 


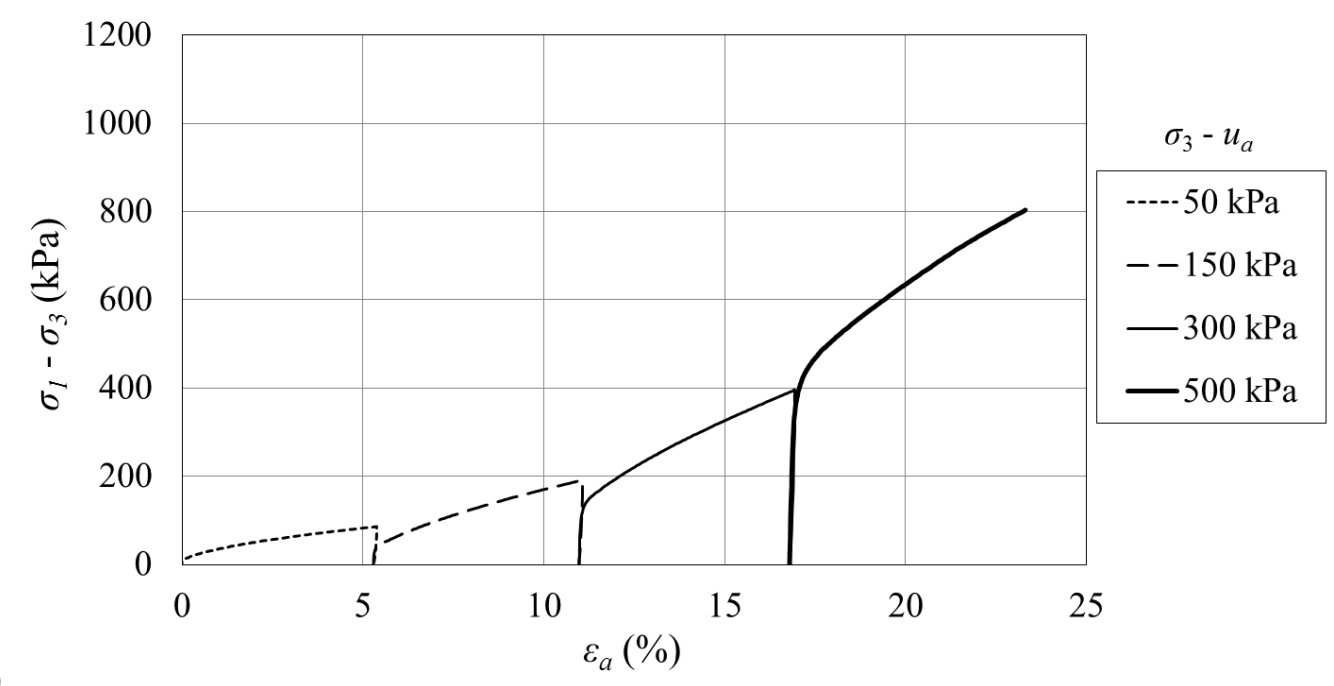

(a)

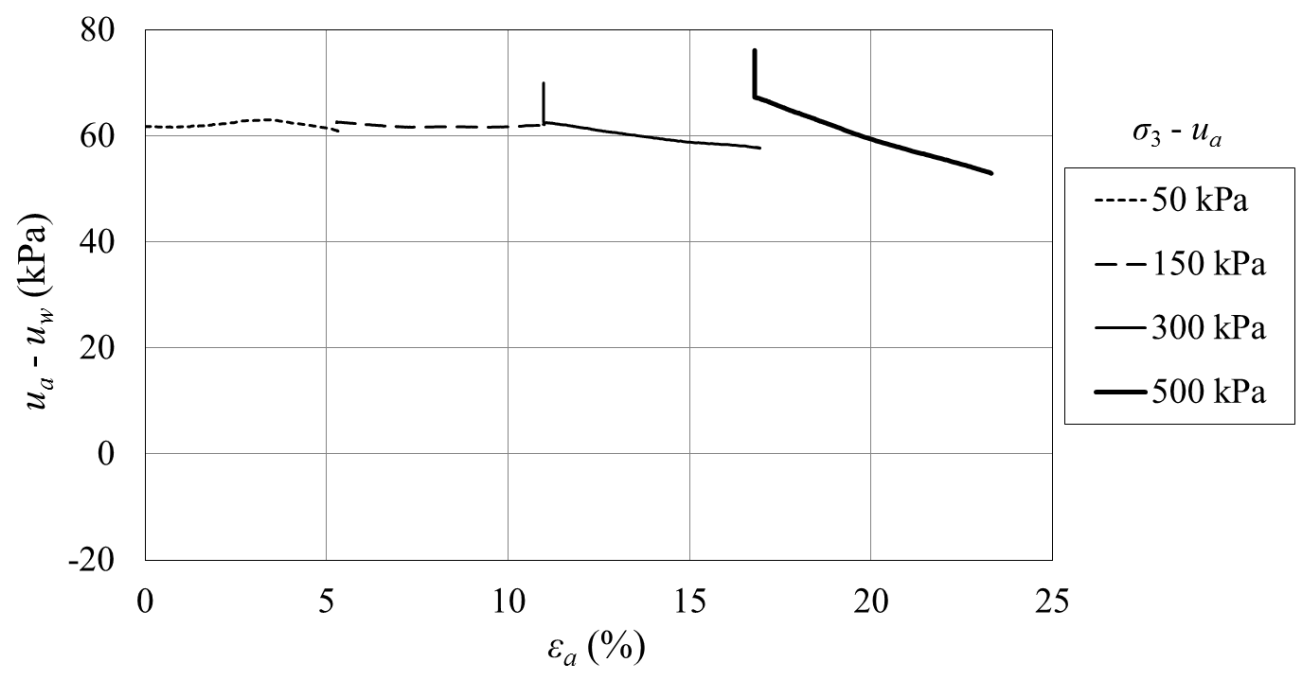

(b)

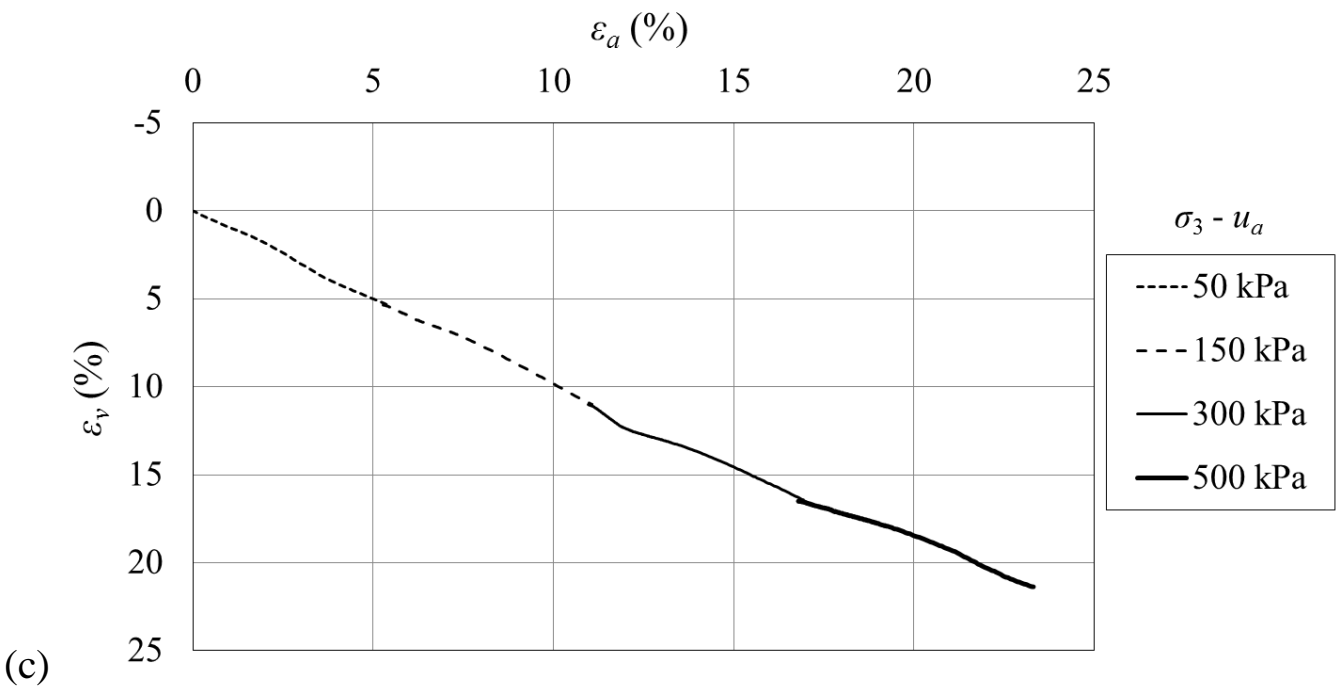

Figura A.4. Curvas (a) tensão-deformação, (b) variação da sucção e (c) deformação volumétrica do ensaio CW com solo indeformado e ensaiado com sucção inicial de $80 \mathrm{kPa}$. 